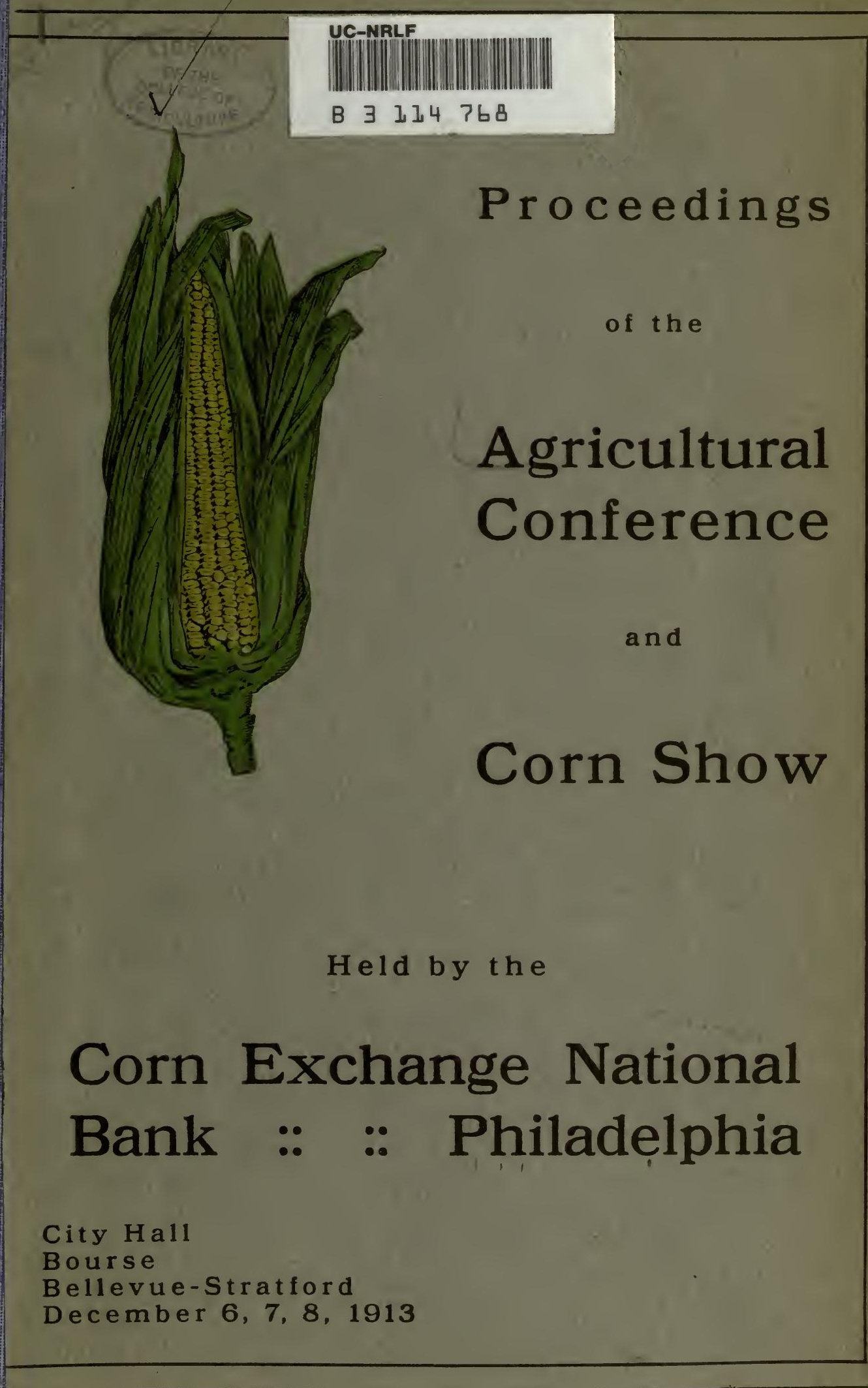




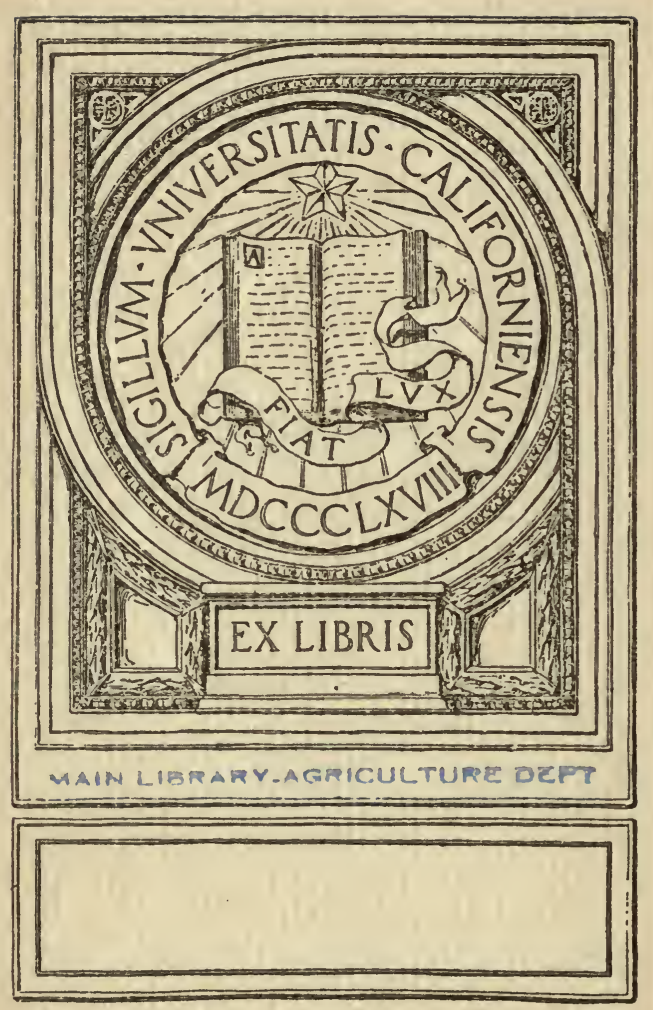




$$
\text { - }
$$

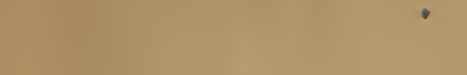





\section{Corn Exchange National Bank Corn Show and Agricultural Conference}

Assisted by

The Commercial Exchange

State College of Pennsylvania

City Club of Philadelphia

Pennsylvania Railroad Company

Board of Trade

Bourse

Philadelphia Produce Exchange

Pennsylvania Rural Progress

Association
The University of Pennsylvania Ohio Society of Philadelphia

Chamber of Commerce

Merchants' and Manufacturers' Association

Hardware Merchants' and Manufacturers' Association

Philadelphia Society for Promoting Agriculture

\section{Philadelphia}

\section{Thursday, Friday, Saturday December 4, 5, 6, 1913}




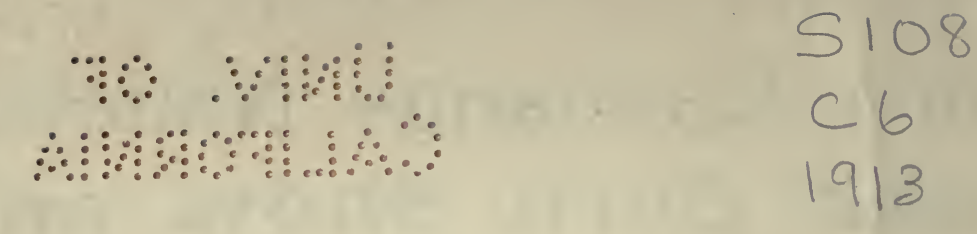

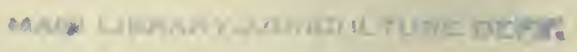




\section{Table of Contents}

Program "reprint" .......................... 5

Address of Welcome. George W. Porter, Director of Public Safety.. 9

Response. Charles S. Calwell ...................... 10

"The Inter-Relation of City and Country." Hon. Thomas P. Gore... . 13

"The Rural Situation." Mrs. Edith Ellicott Smith ........... 24

"Market Conditions." Dean R. L. Watts................. 29

Remarks. Honorary Chairman, Antonio Sans, Esq............ 36

"City Trade Bodies and Agriculture." C. L. Logan............ 38

"Problems in Marketing Eggs." E. W. Benjamin............. 44

"Problems in Marketing Eggs." C. L. Opperman ............ 54

"City-Country Unity Through Market Bureaus." Prof. C. L. King.. 60

"The Economics of the Milk Question." (Illustrated.) ·Dr. John

R. Williams .......................... 73

"Feed Cost of Producing Milk." Prof. C. W. Larson............ 84

Agricultural Extension. Prof. M. S. McDowell............ 158

Remarks. Chairman Clarence Sears Kates, Esq............. 91

"The Rural Organization Service." Dr. T. N. Carver........... 95

"Increasing Grain Production." Don Blair............... 114

"The Farm Bureau; What It Is and What It Does." A. B. Ross... 101

"Trustee, Landlord and the Farm Bureau." Lardner Howell, Esq... 109

Remarks. Honorary Chairman Alba B. Johnson, Esq............ 119

"Necessity for Terminal Markets." Hon. Cyrus O. Miller........ 120

"Results of Railroad Co-operation in Transportation of Farm

Products." Dr. Mary E. Pennington................. 130

"Cold Storage." Frank A. Horne.................... 137

Remarks. Chairman Charles Z. Tryon, Esq............... 150

Ohio Agricultural Commission. A. P. Sandles, President......... 152

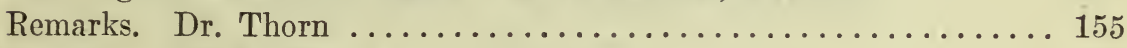

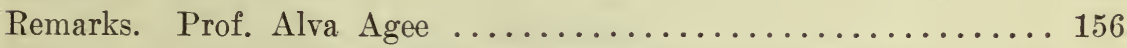

"Boys' and Girls' Corn and Tomato Clubs." (Illustrated). O. H.

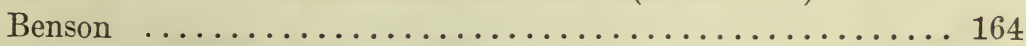

"Boys Illustrating Corn Club Organizing." Russell Lord......... 223

"The Relation of Agricultural Credit and Co-operation to the Cost

of Food in Philadelphia." J. Clyde Marquis........... 175

"The Efficiency Movement and the Farm Problem." Dr. J. Russell

Smith ............................. 179

Address. Charles S. Calwell ....................... 184

Address. B. F. Harris ............................ 186 
PAGE

"The State and the Farmer." Dr. William D. Hurd............ 194 "The Work of a Produce Exchange." N. P. Wescott............ 204 Address. Edward J. Cattell ..................... 216 Pennsylvania Rural Progress Association. Pres. Mrs. E. E. Smith. . 222 "Successful Farming." John Honeycutt ................231 "The Dollars and Cents Question on the Farm." (Illustrated.)

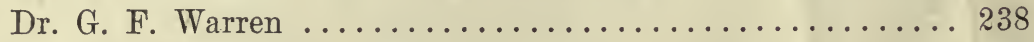

"Agricultural Co-operation." Gifford Pinchot.............. 235 Appendix :

Reprints of folders, etc.

Corn Contest Announcement ................ 251

Suggestions on Selecting Ears............... 257

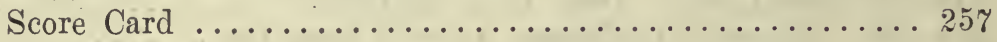

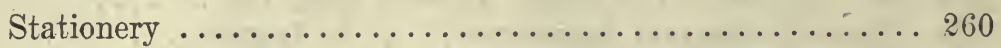

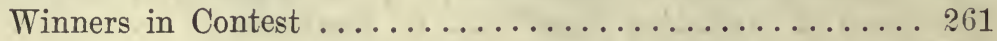

Potato Embargo, Report of

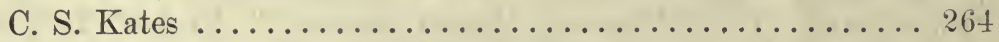

Potato Embargo

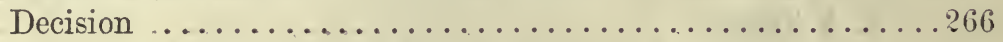

Philadelphia Agricultural Service Bureau

Charles S. Calwell .....................267

C. S. Kates ................................. 111 
[Reprint of Programme.]

\section{CORN EXCHANGE NATIONAL BANK CORN SHOW AND AGRICULTURAL CONFERENCE, \\ Philadelphia,}

Thursday, Friday, Saturday, December 4, 5, 6, 1913.

ASSISTED BY

The Commercial Exchange

State College of Pennsylvania

City Club of Philadelphia

Pennsylvania Railroad Company

Board of Trade

Bourse

Philadelphia Produce Exchange
The University of Pennsylvania

Pennsylvania Rural Progress Association

Ohio Society of Philadelphia

Chamber of Commerce

Merchants' and Manufacturers' Association

Hardware Merchants'and Manufacturers'Association Philadelphia Society for Promoting Agriculture

\section{PURPOSE.}

To demonstrate the mutual interests of the city and country in agriculture.

By presenting the various means for increasing efficiency in the business of farming, such as:

1. Marketing;

2. Transportation;

3. Surveys-Farm and Soil;

4. Farm Bureaus;

5. Corn Shows;

and therefore the advantage of a Farm Bureau for Philadelphia to act as a "Clearing House" for Agricultural affairs for Pennsylvania, New Jersey, Delaware and Maryland.

\section{PLACE OF MEETING.}

All sessions of Conference, except Thursday afternoon and Saturday afternoon, City Hall Council Chambers. Thursday afternoon session, Witherspoon Hall.

\section{CORN SHOW, BOURSE BUILDING.}

OFFICERS.

Chairman, Charles S. Calwell

Chairman Joint Committee

Clarence Sears Kates

\section{Secretary}

C. W. Summerfield
Treasurer

N. B. KELLY

Address all communications relative to conference to

Mrs. Edith Ellicott Simith,

President Pennsylvania Rural Progress Association,

Box 1905, Philadelphia.

Exhibit of the Pennsylvania Railroad Company at Broad Street Station Agricultural Education Train and a Dairy, Refrigerator and Live-Stock Cars. 
[Reprint of Programme.]

PROGRAMME.

PHILADELPHIA DAY.

Thursday, December 4, 1913, 10 A. M.

Council Chambers, City Hall.

Address of Welcome,

Response,
Mayor Rudolph Blankenburg

Charles S. Calwell, President Corn Exchange National Bank

"The Inter-Relation of City and Country," Hon. Thomas P. Gore,

U. S. Senator from Oklahoma; Chairman Senate Committee on Agriculture.

"The Rural Situation,"

Mrs. Edith Ellicott Smith, President Pennsylvania Rural Progress Association.

"Market Conditions,"

Dean R. L. Watts, State College, Pa.

Afternoon, 2 o'Clock. General Topic, "Marketing."

Witherspoon HALL.

HONORARY CHAIRMAN, ANTONIO SANS, ESQ.

President Commercial Exchange

"City Trade Bodies and Agriculture,"

C. L. Logan, Binghamton Chamber of Commerce

"Problems in Marketing Eggs," E. W. Benjamin, Department of Poultry Husbandry, College of Agriculture, Cornell University.

"Problems in Marketing Poultry," C. L. Opperman, Maryland

"City-Country Unity Through Market Bureaus," Prof. C. L. King, Wharton School, University of Penna

Evening, 8 o'Clock. General Topic, "Milk as a Business." CHAIRMAN, CHARLES S. CALWELL, ESQ. President Corn Exchange National Bank.

"The Economics of the Milk Question" (Illustrated),

Dr. John R. Williams, Rochester Chamber of Commerce.

"Market Problems of the Milk Question," Prof. C. W. Larson, State College Pa.

Discussion by Dealers and Farmers.

Agricultural Extension, 
[Reprint of Programme.]

PROGRAMME.

CORN DAY.

The Ohio Prize Corn Growers' Association (two thousand in the party), will visit the Corn Show on

Friday, December 5̆th.

Special prizes will be given by the Corn Exchange National Bank for the best five ears grown by members of this Ohio Association.

\section{Friday, December 5, 1913, 10 A. M. \\ Council Chambers, City Hall. \\ CHAIRMAN, ClaRENCE SEARS KATES, ESQ. \\ Philadelphia Society Promoting of Agriculture.}

"The Rural Organization Service," Dr. T. N. Carver,

Director, Rural Organization Service, U. S. Dept. Agriculture, Washington.

"Increasing Grain Production,"

Don Blair, Sugar Grove, Ill.

"The Farm Bureau; What It Is and What It Does," A. B. Ross, County Agent, Farm Bureau, Bedford County, Pa. "Trustee, Landlord and the Farm Bureau," Lardner Howell, Esq., Girard Trust Company, Philadelphia. Discussion.

Afternoon, 2 o'Clock. General Topic, "Markets: Cold Storage," Council Chambers, City Hall. HONORARY CHAIRMAN, ALBA B. JOHNSON, ESQ. President Baldwin Locomotive Works.

"Municipal Markets,"

Hon. Cyrus O. Miller,

Chairman, Mayor of New York's Committee on Municipal Markets and President of the Borough of the Bronx.

"Results of Railroad Co-operation in Transportation of Farm Products," - Dr. Mary E. Pennington,

Director, Food Research Laboratory, Bureau of Chemistry, United States Dept. of Agriculture.

"Cold Storage,"

Frank A. Horne.

President, Merchants' Refrigerating Co., New York City.

Evening, 8 o'Clock.

Council Chambers, City Hall.

CHAIRMAN, CHARLES Z. LYON, ESQ.

Vice-President Hardware Merchants' and Manufacturing Association.

"Boys and Girls Corn and Tomato Clubs" (Illustrated). O. H. Benson, United States Dept. of Agriculture.

"Whirlwind Alfalfa Campaign" (Illustrated),

Prof. P. G. Holden,

"Boys Illustrating Corn Club Organizing," Chicago Russell Lord, Chairman, Student Committee of the Oread Country Life School, Glencoe, Md. 
[Reprint of Programme.]

PROGRAMME.

BANKERS' DAY.

Saturday, December 6, 10 a. M.

Council Chambers, City Hall.

GENERAL TOPIC, "AGRICULTURAL CREDit."

"The Relation of Agricultural Credit and Co-operation to the Cost of Food in Philadelphia,"

J. Clyde Marquis,

Delegate of the City of Philadelphia to the American Commission on European Agricultural Credits; Associate Editor "The Country Gentleman."

"The Farmer's Thirty-five-Cent Dollar," Herbert Collingwood, Editor "The Rural New Yorker."

"The Efficiency Movement and the Farm Problem,"

Dr. J. Russell Smith, Wharton School, University of Penna.

"Agricultural Credit,"

Dr. John Lee Coulter,

United States Dept. of Commerce and

Secretary of the U. S. Commission to

Study European Credits.

Afternoon, 2 o'Clock.

Bellevue-Stratford Hotel.

(Admission by invitation only)

Address,

Charles S. Calwell, President Corn Exchange National Bank.

Address,

B. F. Harris,

Chairman of the Agricultural Commission of the American Bankers' Association, Champaign, Ill.

"Farm Restoration,"

Forrest Crissey,

"The State and the Farmer,"

Dr. William D. Hurd,

Massachusetts Agricultural College, Amherst, Mass.

"The Work of a Produce Exchange,"

N. P. Wescott, Eastern Shore of Virginia Produce Exchange, Onley, Va.

Eveñing, 8 o'Clock.

Council Chambers, City Hall.

"Successful Farming,"

John Honeycutt,

Business Man and Farmer, Amboy, Ill.

"The Dollars and Cents Question on the Farm" (Illustrated),

Dr. G. F. Warren,

College of Agriculture, Cornell, N. Y.

"Agricultural Co-operation,"

Gifford Pinchot. 


\title{
PHILADELPHIA DAY
}

\author{
Thursday Morning, December 4, 1913, 10 o'Clock.
}

\section{Council Chamber, City Hall.}

The conference was called to order by Charles S. Calwell, president of the Corn Exchange National Bank, who said:

I am sorry that we cannot have with us this morning Mayor Blankenburg. His Honor is not very well, and is at the present time in the South. $\mathrm{He}$ is greatly interested in the conference, and regrets that he cannot be here himself. Director of Public Safety Porter, however, will speak on behalf of His Honor.

\section{ADDRESS OF WELCOME}

Director of Public Safety George W. Porter: Mr. Chairman, and Ladies and Gentlemen: I always state on occasions of this kind that I fail to understand why it is necessary to call in the Police Department, but I am not here this morning as a representative of the Police Department; I am a substitute for the Mayor, who, as most of you know, is unavoidably detained by reason of illness. I have a message from him to explain to you his heartfelt greetings, and to say to you that he regrets more than he can tell, his inability to be with you.

$\mathrm{He}$ made an engagement several months ago to participate in this conference, but, of course, by reason of illness he will not be able to do so.

On behalf of the city, I wish to extend to all those who come from beyond its confines, a most hearty welcome. We are very proud of Philadelphia. We are proud of it because it has been and is an hospitable city. We usually say to those who come to visit us that we know how to entertain you. I am quite sure that the programme that has been arranged by the committee in charge will demonstrate the ability of Philadelphia to do that for which we are quite famous.

I regret that I am unable to speak to you upon the subjects which are to be discussed here this morning, although I am a farm product myself, having served an apprenticeship of eighteen years as a farmer's boy. So, in a measure, I have a right to be here, but my long absence from work of that kind probably does not qualify me to speak on the subject.

It is an old, old saying that the bone and sinew of the Nation are the men who come from the farms. I am quite sure that if we were to take a census of our various cities, we would find them filled with men 
and women who aie the products of farms, and that the great men of today, the great men in the financial world, great men in the business world and commercial world, are the very men who started in their boyhood days as farmers' boys. I think it is just and fitting that our great city should properly recognize the life of the American farmer in his relation to the necessities of city life.

The time is rapidly approaching when the people who live in cities will appreciate more and more the necessity for coming into closer touch with those who prorluce the kind of things that make possible our living in great cities. To the east of us we have a state which, if properly developed, would be one of the garden spots of the world. New Jersey probably stands in the forefront as one of the great trucking communities. I am in hopes that the day is not far off when the State of New Jersey can so rise to the situation that it will so develop the lands which are now lying idle, to enable the men who own the land there, to furnish to the centers of population all the things that you and I like to eat.

In Philadelphia we have in the past two years, endeavored to bring the farmer, the man who produces products of that kind, in closer touch with the city. We have made a careful study of the markets, whereby the farmers can market direct to the consumer the products of their labor. That the plans are not yet consummated is not due to any fault of ours, but I am quite sure the day is not far off when we will enable the Philadelphia citizen to purchase his supplies directly from the man who produces them. Of course, we realize in modern commercial life that everyone who handles these products must of necessity reap some benefit from it; otherwise, he could not remain in business. But we are all selfish enough in our every-day life to try and secure those things we need at the minimum cost.

It has been argued that one way to secure that is to put the farmer and consumer in our cities in closer touch.

That, ladies and gentlemen, is the extent of my knowledge regarding farming. I only want to conclude my remarks by saying to you again, Philadelphia welcomes you most heartily. It is always customary, I. believe, to extend the keys of the city to you. I want to say to you that we have no keys; they were thrown away long ago, and we only have the old-fashioned latch-string, which always hangs out. If there is anything which the city administration can do while you are here to make your stay pleasant and profitable, I want you to feel sure that we are ready to serve you, and all that is necessary to be done is for you to say the word.

I thank you for the opportunity of appearing here. [Applause.]

Mr. Calwell: Right at the beginning, I would like to say that I do not know anything about agriculture, but I am very glad indeed that the City of Philadelphia is beginning to take an interest in this great subject. I thank Director Porter for his kindness in giving us the freedom of the city, and offering to help this movement in every possible way. 
It is going $\mathrm{t}\lrcorner$ be a big movemənt, this movement for the improvement of agriculture. The unfortunate part of it is that the farmer in a great many instances, does not feel that he needs help and pràaps does not want help, but we in the city know that we are paying higher prices for food. We know that riding out in the country, we can see the farm products wasting on the ground, and we have come to the conclusion that the way we can help this movement, for cheaper living, is by studying the question of farm production and transportation and selling. This is not a question of philanthropy at all; it is a question of business. That is the reason that the Corn Exchange Bank is in this movement, and also the reason that the trade bodies have become interested here with us. On the front page of the programme you will see the names of the different trade organizations that are associated with us in helping to solve these problems. In addition to the Board of Trade, Bourse, Philadelphia Produce Exchange and Commercial Exchange, Chamber of Commerce, Merchants' and Manufacturers' Association, Hardware Merchants' and Manufacturers' Association, the Pennsylvania Railroad, the City Club and Ohio Society of Philadelphia, we have the University of Pennsylvania, State College, the Pennsylvania Rural Progress Association and the Philadelphia Society for Promoting Agriculture, all interested in this movement.

There are plenty of means for developing farm lands and of instructing the farmer how to increase his production. But there is more than that to this subject; there is the question of transportation, the question of marketing and the question of meeting the needs of the consumer. Pennsylvania has the largest rural population of any state. We have right here in this wonderful agricultural section, surrounded by the best agricultural country anywhere in the United States-Chester County, Lancaster County and all through the eastern part of Pennsylvania. Take New Jersey: No better section anywhere; also Delaware and Maryland. You cannot find any better agricultural land than we have here. Yet it is selling in some sections for practically nothing. We have a wonderful market here. Six or seven millions of people are right within two or three hundred miles of our homes. Why should we nôt raise enough agricultural products and food supplies for ourselves? We do not do it. You go down along Dock Street and Front Street, and you will find that we are getting turkeys from Texas, chickens and other poultry from Illinois, Indiana and even further west. We are getting butter from Minnesota. You try to find where the Pennsylvania products are, and they tell you that they cannot give you any percentage; it is so small that it is hardly worth noticing. The only way they can use Pennsylvania poultry is by having it shipped in alive and killing it on Front Street; otherwise, it does not come in in good condition.

When the housewife goes to the store and pays a dollar for a dozen eggs and pound of butter, it is time that the farmers around Philadelphia 
should get some of the benefits of these high prices. I believe it is possible to develop in Philadelphia a bureau of information, where the farmer can come and get information about markets, and about fertilizers and seeds; also a bureau where good immigrants could find out where they could locate on good farms. They are running Immigrant Departments in the states out West. Why should we not get some of these good men, men who have gone out to Minnesota and developed farms? Why could not the same thing be pursued up in Bucks County and different locations which have just as good soil? I believe there is great opportunity for development in the southern part of New Jersey, the eastern part of Pennsylvania, Delaware and Maryland.

We are going to take up the question of cold storage and transportation. Judging from the bill passed at the last legislature, we need to take that up and study it a little, because that bill is the worst bill in the United States, and is going to do a great deal of harm right here in this city. You are going to find that butter and eggs are going to be very much higher unless we can get people outside of the state to ship in cold storage goods beyond the time set by the legislature. Why should such a law pass? We ought to think about these laws before they are passed. That is one of the questions that we are going to take up tomorrow afternoon. We will also have meetings here on boys' and girls' corn clubs, and on Saturday the bankers' meeting. So, we will have plenty of discussion, and there is no need in my spending any more time talking on those subjects today.

We have present this morning Senator Gore, from Oklahoma. $\mathrm{He}$ has come from a great distance and is a very busy man. I know he has a lot of figures which he accumulated in Washington. We appreciate Senator Gore's coming here. He is interested in agriculture, and as chairman of the Agricultural Committee of the Senate, I am sure he can give us a message that will help us along in this great movement. I take p'easure in introducing Senator Thomas P. Gore. 


\section{THE INTER-RELATION OF CITY AND COUNTRY.}

Hon. Thomas P. Gore,

U. S. Senator from Oklahoma; Chairman, Senate Committee on Agriculture.

Ladies and Gentlemen: I am obliged to your presiding officer for his very courteous presentation. I must plead guilty to the suggestion that I have been somewhat busy during the extra session and during the recent weeks. Indeed, I might say that my desire to be present and to attest my interest in your organization is proven by the fact that I have torn myself away from an extra session of the Senate. At least, we like to imagine that we are pretty busy down in Washington, and especially do we like to have other people imagine that we are pretty busy in Washington. Yet I believe that nothing which Congress ever does seems to give such universal satisfaction as its adjournment. The people generally seem to look upon the adjournment of Congress a good deal like an old darkey I used to know in Mississippi. If any of you people come from that region you know that there is nothing that the southern darkey enjoys better than a funeral. On one occasion an old Uncle was returning from one of those outings, when he happened to pass one of the white laborers by the way. The. white man says, "Hello, Uncle, Brown is dead?" He says, "Yes." He said, "What seemed to be the complaint?" "Well, sir," he replied, "I ain't heard no complaint yet; it seems to give pretty general satisfaction." [Laughter.] That is the way the country generally seems to look upon the adjournment of Congress.

Now, my friends, I appreciate the opportunity to be present. I have come to attest my interest in the purposes and in the objects of this organization. As chairman of the Committee on Agriculture of the Senate, I wish to set the seal of my approval, for whatever that may signify, upon this organization, and upon all other organizations which seek to promote the progress and prosperity of agriculture in this country, and which seek to bring about a better understanding and a better relationship between the residents of the city and the residents of the country.

There are many organizations, and a growing interest in this subject, as proven by the multiplication of societies dedicated to the betterment of rural life. I hope to see a consolidation of many of those societies and many of those organizations, and -I hope to see the co-ordination and cooperation of them all. In division there is waste; in union there is efficiency, and while we counsel the elimination of waste and the stimulation of efficiency as one of the great means for the betterment of agriculture, 
we are still guilty, to a great or less extent, of waste and inefficiency on the part of those who seek the elimination of those very evils.

I come to assure you of my disposition and, I believe, the disposition of Congress and the administration, to promote in every possible way the improvement of rural life and aid in the solution of the problems of rural life, which are but the problems of our national life. We have not devoted too much time, we have not devoted too much thought to the problems of the city; we have not devoted too much attention and have not rendered too much assistance to the enterprises and industries of the city, but we have devoted too little time and too little thought to the problems of the country, to the problems of the farm, to the larger problems of our national life. No one can choose but wish the utmost progress and prosperity to the enterprises of mining and manufacturing, to the means and facilities of exchange and distribution, but to the primary industry of production we have not in the past devoted sufficient thought, sufficient attention and sufficient enlightened study. There is coming a new time when we shall no longer be guilty of this dereliction of our duty. Tried by every standpoint, agriculture is of the very first import. I do not suggest this by way of instituting any invidious comparison. Manufacturing, mining and commerce are of supreme importance to national prosperity, and to individual happiness. I merely suggest that of primary and preliminary importance stands agriculture in the scale of our national economy. Tried by the standard of value merely as an investment, agriculture stands at the head of the list.

In this country we have thirty-four billions of dollars invested in agricultural production. In improved and unimproved farm lands there are 788 millions of acres. So, the annual output of the American farm is more than nine billions of dollars. Tried by the standard of numbers merely, viewed from the standpoint of population, agriculture is of preeminent importance. More people are engaged in agriculture than in any other single industry or pursuit in the United States. One-third of all the people engaged in gainful occupation are devoting their time, their talents and their energy to agriculture. Tried by the standard of permanence agriculture is of foremost importance. It is the oldest settled industry amongst the sons of men. Hunting and fishing and herding have had their time of ascendency, but that time has past. Agriculture will not pass; it must abide with us so long as civilization obtains amongst us. It is the only means by which a large population can be sustained upon limited territory. Judged by its origin and vital necessity, it is, of course, the foremost occupation. It is the very source of our existence. It is the foundation from which flows the means of subsistence. It is needless for me, and I do not intend to enlarge upon the necessity or indispensability of agriculture. This is known to you all. There are problems connected with this which I wish to state, which I do not intend to solve, and which I could not solve at this time. 
We hear much complaint about the drift of population from rural districts to our cities. Under the first census only three per cent of our population were classified as urban. Under the last census forty-six per cent of the population resided in cities and towns as classified under the census regulations. There are reasons why this tendency persists, and with those reasons we must deal, if we would counteract that tendency. Some of the reasons cannot be counteracted, some of the reasons ought not to be counteracted. There are others, however, which are temporary, which are artificial, and which ought not to obtain, and which ought to be arrested, or which ought to be counteracted.

There are many means which we can employ to encourage the residents of the rural districts to remain and not to join in this procession or in this mad rush from the farm to the factory, from the country to the city.

Now, here is another fundamental problem which I will raise at this point, not with the view of submitting an ultimate solution. The population must grow if the nation is to increase in strength and greatness and, I may add, in glory. We must not aspire to be a stationary people, but a growing and multiplying people. In our problem the factor of population is an increasing factor. The pressure of population upon the means of subsistence must increase, and this raises what has been known as the Malthusian theory. This pressure of population upon the means of subsistence will increase until hunger and famine are threatened, if not realized. In this country today we have only about thirty people to the square mile. In Belgium there are more than five hundred people to the square mile. In taking invoice in analyzing this problem, we must deal with the factor of population as a constantly increasing factor, for none of us would consent to that factor becoming fixed or becoming stationary.

Now, the area of land is a fixed factor. It does not increase; it cannot be made to increase. There are variable factors, however, which are subject, in a large measure, to our control, and which must be controlled if we are to meet the requirements of an increasing population.

Fertility is not a fixed factor, but it is really subject to our management and subject to increase. Tillage, improved tillage, is not a fixed factor; it is a variable factor. It is one that can be influenced by the will and by the activities of man.

Upon these factors, then, we must concentrate our intelligence and our energy. There we must find the solution of our problems. There we must relieve the pressure of population upon the fixed land area and upon the means of subsistence. It was declared about two hundred years ago that tillage was fertilization.

Now, our mines and our forests ought to be conserved. The conservation of our forests is one of the great national problems, which is entitled to that deep solicitude and attention which it has received during 
recent years. Unfortunate it is that this attention was not sooner directed to the conservation of our vast forest resources. In many localities they have been exhausted and in many localities they have been impaired. Perhaps in every locality until in recent years those resources have been neglected. National interest and patriotism have devoted themselves to the task of arresting this waste, this dissipation of a resource which can be rebuilded only through a long series of years, rising almost to the century mark. Our mines have been wantonly worked and wasted in the past. Unlike the forests, they cannot be recuperated, even with the lapse of centuries. Once exhausted, a mine is always exhausted. It becomes a reminiscence. It becomes one of those cemeteries where the dead past continues to bury its dead. We can only reduce, minimize or eliminate waste in the operation of mining and in the use of the output of the mine. We cannot restore to life the exhausted mine or the exhausted ore. Waste is the evil to which the soil is equally liable. There are those who mine the soil instead of tilling the soil. This is our greatest resource, resource upon which collective society depends for its existence and upon which every individual depends for his maintenance and for his existence. The growing or grown-up individual must rely upon the soil for his subsistence as relies the babe upon its mother's breast. The beggar in his rags and the prince in his purple depend alike upon the fruits of the soil for existence and for life itself.

I cannot say more-I need not say more to accentuate the indispensable necessity of this resource and of its conservation. The exhaustion of the fertility of the soil is a national calamity. This exhaustion has run rampant in the past in this section and in many sections of the union. The abandoned field is seen as an enduring monument to the waste which has run riot in other days. The fertility of the soil is our greatest patrimony. It is the national heritage. True, we have ownership of land in severalty in this country, yet every individual and society collectively has a direct interest in the conservation and in the maintenance of the fertility of the soil.

Improved tillage upon fertilization is the other means and resource upon which we must rely, in order that a fixed land area may meet the requirements of the increasing population, in order that the Malthusian theory may never come to our door as the wolf of want.

The possibilities of fertilization and of tillage hardly have limits. Their capacity is almost unlimited. I remember in the vicinity of Paris 2 7-10 acres which produced 250 tons of vegetable product. In Egypt 900 people are maintained on a single square mile under irrigation. The number rises to 1,200 in portions of India, and in the Empire of Japan there are 45,000,000 souls and the tillable land amounts to less than 20,000 square miles, less than the area of New Jersey and Maryland combined.

By proper fertilization and by proper tillage this country will be able to meet and maintain all the requirements of an increasing popula- 
tion practically without limit. It cannot be done, however, if we neglect these resources. This, then, is the paramount problem and the supreme duty alike of nation and of state. I rejoice to see your society, your organization and other organizations devoting themselves to the remaining phase of this problem. Science has discovered all the principles of fertilization and tillage. The truths of agriculture are known to the scientists and they must be made known to the farmer. Our light is of little aid if it remains under a bushel. The man who tills the soil, the man who farms the farm, must be made conversant with these principles, not only that they must be induced to apply these principles to practical farming, they must not only be taught-they have been taught-that brains mix with the soil better than bone dust; but that intelligence is as essential to successful farming as is the sunshine. But it is our concern, it is the concern of the country, it is the concern of the city, to see that these principles are mingled with the soil itself. The duty devolves upon the state, upon the Federal Government to disseminate the truths and principles of scientific agriculture, to induce their practical application:

It is fortunate that societies of this kind are formed to reinforce the activities of the state and of the general government. A bill is now pending* before the Committee on Agriculture which I hope to see reported on Tuesday next, providing for farm extension and for farm demonstration work in every state in the union. This work is to be carried on in conjunction with our agricultural colleges, the purpose being to carry these principles to the individual farmer and to stimulate their adoption and their use by the individual farmer.

Societies of this kind can do a great deal to overcome prejudice where prejudice exists and to overcome suspicion where suspicion exists. Your organization ought to bring about a closer understanding and co-operation between the cities and the country with a common purpose in view. You should co-operate with the farmers, not as patron with dependent, not as master with student, but as common citizens and co-laborers, animated by a common purpose addressed to a common object, inspiring a feeling of fraternity, of fellowship; of mutual trust and co-operation, that neither one nor the other is attempting to become or is attempting to prey upon his fellow, but is attempting to serve his fellow. The greatest obligation which any man owes to his fellow, or unto society itself, is the obligation of service.

Now, there are several ways in which I hope to see the Committee on Agriculture of the Senate become more serviceable in the future than in the past to the farm and farmer of the United States. We ought to have in this country a system of farm credits suited to the conditions of our country and to the needs of our farms. - Farm credit systems have grown up in the several countries of the old world, in Germany, in France, in Italy; and such systems are now being installed in England, Scot-

* This bill (the Lever Bill) has since been passed and signed by the President. 
land and also in Ireland, systems which enable the farmer to employ his credit when he needs his credit. The farmer's credit is part of his possession; it is an asset, and it ought to be made available unto him whenever he requires it and whenever he can use it to his individual advantage or to the advantage of his community.

These systems have grown up in the old world, systems adapted to local conditions and to the local needs of the people. It was my pleasure to offer and secure the adoption of an amendment to the last agricultural bill, raising a commission to visit Europe to study those systems and report upon them. This commission has visited Europe. It was in session yesterday and will submit its report at an early date.* These systems of rural credit will not interfere with and they will not overturn our established commercial institutions and not interfere with the existing banking system. They are to supply a need which our present banking system is not suited to supply, a need which they do not at present meet, but a need which ought to be met either by the establishment of new institutions suited to the purposes or by the readaptation of the existing institutions, not only personal credit systems, but land credit systems. I submit one solution. In Europe they borrow money upon land for long time periods at a low rate of interest. A loan of a thousand dollars, for instance, will be repaid during a period of fifty-four years by annual payments of $\$ 48.50$. This pays the principal and liquidates both principal and interest and pays the operating expenses of the institution. An annual payment of $\$ 48.50$ is easily met. A system of this sort in this country would provide securities for the investment of hoarded money, would enable the farmers to enlarge their farms and improve their farms, and would enable the younger men to purchase farms, as well as to improve them. The long time and the low rate moderates the burden, so that his energies can be devoted to improvement, so his credit is rendered available and is made a real asset, serviceable alike to himself and to the community.

I think that Congress will at an early date pass a measure looking to the establishment of systems of farm credits of this character. This should be encouraged alike by those engaged in commercial banking and by the community at large.

Another respect in which the Committee on Agriculture can be of service to the farmer is in the establishment or in encouraging the establishment of improved market facilities throughout this country, not only in our larger cities, but in every section of the country. Much progress has been made in this direction in some European cities and in some of our own states, California and Florida, for instance.

It is admitted by the Department of Agriculture that more than $\$ 25,000,000$ is wasted every year in marketing the cotton crop of the

*The Commission has published the first installment of its report-Agricultural Co-operation and Rural Credit in Europe. Senate Doc. No. 204. 
South. While this is of no direct concern to you, yet you must but feel a sympathetic interest in this important subject. Seventy-five million dollars are wasted to the farmers of the South through the want of improved market advantages. I might say here that we ought to raise the standard of warfare against waste - waste in private affairs as well as waste in public affairs. This standard should not be lowered until this warfare concludes in complete conquest, in complete triumph. Waste is uncivilized. It must be eliminated before we attain the highest standard of civilization.

Now, the farm products of the United States aggregate more than nine billions annually. Perhaps a third of this is retained upon the farm for domestic consumption, and something more than six billions are marketed annually by the farmer. The farm products bring the producer about six billion dollars annually, but when these products are retailed to the consumer, they bring thirteen billions of dollars. There is a spread of seven billion between the price received by the producer and the price paid by the consumer.

Now, it is impossible to believe that there is not much of waste, much of needless profits in this vast amount of seven billion dollars. This waste is due largely to the want of marketing advantages, marketing facilities, to the want of centralized intelligence, to the want in one locality of the supplies available in other localities.

The problem of the high cost of living must receive at least a part of its solution in this quarter. The producer could easily receive two billions more, and the consumer could easily pay two billions less and both would be vastly benefited, and yet there would be a spread of three or four billions to pay for the ultimate requirements of exchange and distribution. Of course, these estimates of figures are generalities, but they point the problem, the place where the solution must in part be applied.

I am pleased to report to you that when the agricultural appropriation bill was passed in March last the Senate attached an amendment, creating a market bureau in the Agricultural Department. In conference we were obliged to surrender that section, but we retained an appropriation of $\$ 50,000$ to enable the department to make a study of marketing conditions and facilities in Europe and in different sections of this country. Dr. Carver, formerly of Harvard University, and perhaps the highest authority upon agricultural economics, in this country, has been placed in charge of this work. He recently visited Europe, and the country will at an early date begin to realize the fruits of his researches and investigation.*

The appropriation bill; passed during the present session, will increase the amount from $\$ 50,000$ to $\$ 150,000$ and possibly $\$ 200,000$. There is no economy in closing our eyes against the light; ignorance has no advantages, but enlightenment has infinite advantages. We must lay our hands to the solution of this problem, and whatever waste exists, if any, in our present marketing conditions, must be eliminated. The advantages

*The Bureau of Markets has since been organized and is in active operation. Dr. Brand is chief of the Bureau. 
which can come from the most improved methods must be secured alike to our farmers, to the producers of the country and to the consumers of the country. Your organization can assist in the solution of this problem, as in the solution of other problems, but when our farms have been fertilized, when they have been wisely tilled, when the farmer has been provided with credit upon reasonable terms, and, then, there is still one other service which the general government, in conjunction with the state government, can render to the farmer of this country. I allude now to the construction and maintenance of a system of improved highways. It is difficult for us to excuse ourselves - in fact, we cannot excuse ourselves for neglecting this important subject for most a century. We are two thousand years behind the Roman Republic, the Roman Empire.

With respect to public highways, we have no system, no national system, and we have no system in a majority of the states. Only twentytwo states have made even an effort in the direction of the development of the highways, and in the direction of devoting scientific thought to the construction and maintenance of a system of public roads.

Congress expends from $\$ 20,000,000$ to $\$ 50,000,000$ a year on rivers, few of which are navigated. We spend from $\$ 15,000,000$ to $\$ 25,000,000$ for public buildings, few of which are indispensable to the efficiency of the public service. With respect to highways we have heretofore made no expenditures, excepting a mere trifle, to stimulate interest.

Now, the purpose of this expenditure is legitimate, the stimulation of interest is the principal object which the general government ought to have in view. The average haul amongst the farmers is nine miles. These roads ought to be constructed, in the main, by the people of the locality which they penetrate. The taxation ought to be a local taxation, so that the people can know whence it comes and whither it goes. Most of the people can have little direct concern in rural routes from the eastern to the western sea. These are not matters of indifference. I hope to see the Lincoln Highway constructed from the Atlantic to the Pacific. Indeed, I have become a subscriber to the fund. I hope to see the road constructed from Winnipeg to the Gulf, because that will stimulate interest and inspire imitation.

My friends, it is estimated by experts that every time the sun sets, the farmers of the United States have lost a million dollars between the rising and setting of the sun, on account of our neglected public highways, the waste of time, waste of energy and wear and tear on team and vehicle-one million dollars a day, aggregating during the year more than three hundred millions. It is hard to estimate the necessaries and comforts which this three hundred million dollars would supply if this waste were eliminated and if this amount were applied to the purchase of comforts and of necessaries.

I say stimulation of interest is the principal purpose which ought to animate the general government. Sufficient money is expended now for 
the construction and maintenance of a magnificent system of highways. Approximately two hundred million dollars a year are paid by the people of this country in township, county and state for road purposes, and yet we get no roads, excepting in a few states like New York, Pennsylvania, New Jersey and a few others in New England and one or two in the West, Wisconsin and other localities. In my own state the people contribute three million dollars a year for the construction of roads, and yet we get no roads except what nature has provided. There she has been generous. We have the best natural system of roads in the world. I have to say that, because I am a candidate for re-election and I have got to say something about the roads.

The trouble is we have a small unit and a small road district. There is no centralized authority, no concentrated intelligence, no general direction. It comes from the ground up. There is no one anywhere charged with power or duty of formulating a general system of public highways. Only yesterday I introduced a bill in the Senate designed to secure co-operation between the Federal Government and the State Governments, and to give general direction and supervision, so as to insure a system of national highways. The state is required to put up a dollar for every dollar appropriated by the general government. That is an effectual safeguard against what is known as the pork barrel. For my own part I am opposed to every form of pork barrel, whether it be known as appropriation for rivers and harbors or not. I approve of generous appropriations for the improvement of rivers and harbors, which are actually used in commerce, trade and navigation, but not the pork barrel. I have no penchant for the pork barrel. I am not going to waste the people's good money in the name of good roads. Such a measure as I have suggested will be a blessing to the people of the United States and will redeem our reputation from a charge which can be justly brought against us - one not only of indifference, but of neglect, touching a subject of the highest concern both locally and nationally.

There are other ways and means in which the Committee on Agriculture in Congress can be serviceable to the farm and farmer. I shall not levy a higher tax upon your patience by proceeding further with the discussion. I may repeat that I have appreciated the compliment implied in the invitation to be present today. I embrace the opportunity with pleasure, I am glad and happy to have met you, happy to have been able to assure you of my deep interest and my abiding sympathy in the purposes and in the object of your organization, happy to be able to assure you of my interest and intention to co-operate with your organization and with all other organizations which you can create to promote the advancement and prosperity of the farmer and the farm, which cannot but have a reciprocal advantage on the prosperity of our cities.

We expend every year on our army and navy the sum of $\$ 250,000,000$. We spend upon agriculture about $\$ 17,000,000$. We expend upon the 
army and navy enough every year to construct homes sufficient to house a million people. We expend upon the bloody arts of war $\$ 250,000,000$. We expend upon agriculture, the fruitful arts of peace only $\$ 17,000,000$ a year. Of course we must deal with conditions as they are. I wish it were possible for us to arrange with all the powers of the earth to let the Republic stand for one brief year undisturbed and undestroyed, so that during that brief year we could expend $\$ 250,000,000$ upon agriculture, upon internal improvements upon rivers and harbors, upon public highways $-\$ 250,000,000$ to make life worth the living, and expend only $\$ 17,000,000$ preparing for the butchery of our brethren.

Of course, I know, and you know, that the Golden Age has not come and, perchance, is not coming, when the war trumpets shall throb no longer, and the battle flag be furled; but let us hope the tendency is toward the time when the nations of the earth will cease to determine which is right and which is wrong by the amount of bloodshed and slaughter one is able to inflict upon the other. Let us hope the tendency is towards the time when we will regard as the greatest hero the man who makes two ears of corn grow where one had grown before, or, what is better still, makes one ear of corn grow where none had grown before. I hope the tendency is toward the time when we will look upon that man as a greater hero than he who takes a city, when we will regard the man with the hoe a more glorious citizen, and a more useful citizen, than the conqueror who wades through slaughter to the throne.

Mr. Calwell: We all appreciate that address of Senator Gore's. It has been practical. We are very glad to be in closer touch with the service the Government is rendering and is going to render the country in that farm extension work it is going to make in every state. That sounds like a very good idea to me. I would like to ask if Senator Gore would let us have some information about that bill, the number of the bill or what the bill is called, so that this organization and the bankers of Pennsylvania, New Jersey, Delaware and Maryland will be able to get together and request their senators and representatives to take an especially active interest in that work. The Senator also mentioned the waste in cotton of $\$ 25,000,000$ and said perhaps we had a sympathetic interest in that statement. We have a very active interest in that. Philadelphia is the cotton yarn center of the United States. We have a ticker in the bank, and more people come to see the quotations of cotton than come in to see the quotations of the stock exchange. Every manufacturer in Kensington and Manayunk is complaining today of the rise of the cost of cotton yarn. So we are just as interested in saving that $\$ 25,000,000$ as Oklahoma or any other state in the West or the South.

Dr. Carver was mentioned in connection with the Market Bureau. We are going to have Dr. Carver speak to-morrow morning, and I think 
it will be well to amplify that fact, so that you can come and hear what he has to say regarding this market bureau.

Time passes, and I cannot say anything more except to introduce here the president of the Pennsylvania Rural Progress Association. Mrs. Smith has been quite active in this movement and has had much to do in shaping the programme and the work of the conference. She knows, as few others, the actual conditions in the rural districts of Pennsylvania. I take great pleasure in introducing Mrs. Smith. 


\section{RURAL CONDITIONS.}

\section{By Edith Ellicott Sмith,}

President, Pennsylvania Rural Progress Association, Pennsdale, Pa.

The conference which is now beginning in this city is only another indication of the awakening of the business men of the United States to the need of concerted action on their part for the improvement of country life and agriculture, because of the close interdependence of city and country. To those who are in close touch with the rural districts the constantly growing unrest among the agricultural classes has been fully apparent. By city men, except as they are farm owners, this has only been faintly realized. The unrest which has been growing in the country has been brought about by many causes, both economic and social. A belief on the part of young people and women on the farms that country life is dull drudgery and that a brighter happier life lies in the city seems to prevail.

Farm labor has become more and more discontented. We have a man farming for us who has four sons; two of them as soon as they reached the age of eighteen left for the city to become mechanics; the other two have not a good word to say for farm life and are panting to get away. They will go as soon as they are eighteen. Nearly every day some farm hand appears at the office with complaints about his work, his wages, his hours. Adjustments in and out of reason are made, days off are given, a horse for going visiting, every concession to induce them to remain. Extra labor for pressing seasonal occupations, such as harvesting, filling silos, etc., is almost impossible to find. To solve this problem every rural community will have to co-operate in establishing some winter industry to hold the labor supply. The interchange of labor between farms has been tried and found to be wholly unsatisfactory, because a farmer must always return the favor at the time convenient for his neighbor and most inconvenient for himself.

\section{The Farmer as a Seller.}

The need for a closer relationship between the food producer and the food consumer and the elimination of the class which preys on both, is the talk of the hour, and will only cease when full knowledge regarding the market situation is in the hands of both producer and consumer. At present the farmer knows not to whom his product goes any more than the city man knows from whom his food comes. Neither does the farmer in a vast majority of cases know how to prepare his product for market. 
If only the Farmers' Institute force, which sends five speakers to nearly every village and town in each state to talk on technical agriculture, would advertise one demonstration meeting for each of these villages showing how to prepare chickens for market, how to pack apples, etc., farmers would attend these meetings and the state's funds would not be wasted in holding large numbers of meetings which are but poorly attended. It is no longer a problem of the first importance how to make two blades of grass grow where one grows now; the problem is where and how to market what the farmer has already grown.

If a prosperous and contented class is desirable on our farms and if a reasonable priced food supply is essential to city dwellers, some closer touch and clearer knowledge must be brought about. At present there is a strong belief on the part of the consumer and producer that a sinister and malign influence is at work in hidden ways to rob both parties. Public knowledge of the subject will undoubtedly show that the devil is not as black as he is painted. Ignorance raises barriers which knowledge might level. The expense of transportation and handling the farmer's product is large. But at present it is made out to be so large that neither the man who grew it nor the man who eats it is considered. After an investigation of five hundred dairy farms in western New York, Dr. John R. Williams, of Rochester, discovered that the average investment required for operating a dairy farm in western New York producing 160 quarts of milk daily was $\$ 9,000$. One dealer in the city can easily deliver the milk of three such farms. His total investment rarely exceeds $\$ 2,500$. Thus three farmers in the country with an average investment of $\$ 27,000$ receive no more for their product than one distributor in the city with not more than one-tenth the investment, and the risks and labor of the farmer are really much greater.

\section{The Farmer as a Buyer.}

In the country districts where the farmer is a wholesale buyer he is treated as if he were a retail buyer. He buys thousands of pounds of wire fencing, horse shoes, hardware of all sorts, feeds and fertilizers by the hundred tons and agricultural implements of expensive sorts. But his local dealers treat him as if he were the housewife who is buying a pound of sugar or a quarter pound of tea. He gets very little more consideration for a big order than for a small one. As a result, when he has cash he is buying of the mail-order houses rather than deal with his local merchant, and his local merchant when he has no cash and wants credit sells him a poor article at a high price. A state of anger and resentment exists between himself and the local merchants. This summer we had oceasion to buy fifty window-sash for a dairy barn. We got an estimate from three local planing mills for this work. Their price was $\$ 1.75$ per window. We asked them if they could not consider some reduction on account of the size of the order. They said it was impossible. We 
ordered the windows from Sears, Roebuck \& Co., Chicago, and got them for $\$ 1.25$ a window, including freight. The local planing mills have one price for local orders and another price for orders from nearby cities where they have more competition. The farmer can buy southern pine lumber at $\$ 8$ to $\$ 15$ a thousand and it costs him less even paying freight than to buy lumber from the local dealers who would charge him $\$ 25$ to $\$ 30$ a thousand for the poorest.

The question of feed in the farming districts is also serious. The following instance in Tioga County has come to my knowledge. At the present time the farmers are selling off their cows for almost anything they can get, whole herds going for a song, because the dry weather last summer killed the pasture and hay, and the corn crop is almost a failure. The local mills are selling feed for not less than $\$ 30$ a ton. Consequently the farmers must sell off their herds, as they cannot buy at this price. It will be at least five years before they can regain their present status. Even supposing this matter only concerned the farmers themselves, such a condition is tragic. What makes it right that the mills should charge $\$ 30$ a ton for feed? I sell my wheat for 85 cents a bushel, and out of that wheat the miller gets flour, bran, middlings and shorts to double and treble his profits. Pennsylvania farmers are in many places so hard pressed for cash that they must sell all they can at the lowest price when the markets are glutted in the fall and buy back on credit at high prices in the spring.

\section{Protection Needed.}

The seed situation is worse in the rural districts than almost any other. Such a thing as good seed is unknown. If the farmer sends away to the big seed houses he is just as likely to get more weeds than good seed, or to get seeds ten years old, which may or may not germinate. Much has already been done in guaranteeing fertilizers, yet much remains to be done. Misleading labels are still seen on fertilizer bags. On account of scientific knowledge necessary for the proper using of fertilizers, the average farmer is at a disadvantage in any case. Analysis of feeds is of the highest advantage to the farmer, and the more upright a state government is in this matter the more it can serve the farmer and through him the state. There is great possibility of graft in the whole matter as it stands at present.

These are only a few instances of the unprotected situation of the farmer, the situation which he cannot remedy and from which, if he is worth conserving and is a useful citizen of whom the country has need, he must be delivered. That he is a desirable citizen and belongs to a more essential class than any other has been realized by all the countries of Europe and by none more so than by Denmark.

Here I wish to pause to recommend to the careful study of this municipality and of its large seed houses the work done in Denmark by 
a seed house in putting on the market seed which had been tested and whose viability and purity could be vouched for. The work of this firm obtained such significance that the government took over its plants and farmers are planting only first-class, weed-free, tested seed. Now, since the various farm crops and products are of far more value to the nation than all the organized dealers of all sorts, taken severally or taken together, it stands to reason that it is the business of this nation to see that the farmer gets fair play and a square deal. It should be impossible for any foul seed or seed which is diseased or bad to be put on sale in even the smallest country store. Fines can be imposed and seeds tested by government inspection which will soon make it impossible to furnish low grade seed at high prices, as is now too frequently the case. By testing cabbage seeds State College, Pennsylvania, has found that varieties sold as early are frequently late, that vast quantities of early cabbage do not mature until late, which will often rob a market gardener of his whole early cabbage crop. This is equally true of all other truck and farm seeds.

After all, we are perhaps asking why should the farmer be protected more than any other class? The answer is very simple. He operates on a small scale; his profits are small as compared with many other businesses. He must have ready to his hand when the seasons come round a reliable source of supply for all his needs. He cannot rush about the country hunting up his seeds, fertilizers, feeds, etc. He must accept what he is sold by dealers. If he alone suffered when the crops failed there might be some who would decline to protect him, but since we are all dependent on him it is our duty to conserve the farmer.

\section{Farm Credit.}

Of the bitter need for a better system of credit for farmers I shall leave it for those more expert than I to speak. That this need exists I am well aware. That better facilities for it must be brought about I am very sure. In the meantime, I want to point out that the righting of these wrongs is up to the cities. The farmer can scratch along somehow, he can still feed himself and his family, but if the city food supply is scarce and dear, remember that at present there is no inducement for the farmer to increase it. With fair conditions and a comprehension on the part of the municipalities that they can better existing conditions, there is no reason why the eastern United States should not become as prosperous an agricultural section as, the West. For one thing is pre-eminently true, that we have but barely scratched the surface of our agricultural possibilities.

Mr. Calwell: My attention has just been called to the fact that the Pennsylvania Railroad has on exhibition at Broad Street Station a train of agricultural and dairy cars. You are all invited to inspect them some time during the next two or three days. 
We have heard some slight criticism of State College, that it was not getting into this work as broadly as it should. I am not a State College man, and we are some distance from State College, but I can appreciate the handicaps that State College has had. State College has had practically no consideration from the legislature of Pennsylvania up to this last session. I think that our state representatives and senators now are fully awake to the state needs of agricultural development. The appropriation at the past session was very much increased, and I hope at the next session it will be five times as much.

Dean Watts, of State College, Pennsylvania, is with us today and is going to talk on "Market Conditions." . The criticism of Mrs. Smith was not directed towards Dean Watts at all. He has labored under handicaps and has done a remarkable amount of good. I believe the time is coming now when he is going to get a great deal more money and a great deal more help, not only from his own college, but from the representatives of Pennsylvania and from other associations down here in Philadelphia. I take great pleasure in introducing Dean Watts, of the State College. 


\title{
MARKET CONDITIONS.
}

\author{
Dean R. L. Watts, \\ State College, $\mathrm{Pa}$.
}

Ladies and Gentlemen: I can assure you it is a great pleasure to appear in this conference as the representative of your agricultural college. This institution does not belong to President Sparks, his faculty or the trustees, but it is your college. While we have almost 1,200 students studying agriculture, we feel that one of the most important lines of work of the School of Agriculture of the Pennsylvania State College is to take the College to the farmer. We know that an exceedingly small percentage of your sons and daughters-the young people of this state-will ever find it possible to come to the College. There are 225,000 farmers in Pennsylvania and we have in the College over 1,000 of them, but this is a very small percentage of those who must have help. So that we realize that our great problem is to take the College to the farmer and help him solve his problems right on his own ground.

I have been requested to speak on market conditions and I wish to discuss this topic with special reference to Pennsylvania. The interests of the city and country are mutual. Whatever is beneficial to the farmer will usually help the city man. We hear a great deal in the country about the high cost of living in the city. Occasionally, when we drift into the city restaurants, we wonder how in the world the city man can make both ends meet; and when you talk to the farmer, he will in all probability tell you that his profits are not any larger than they were a few years ago. We realize that city consumers are paying more for food than they have paid for many years, but producers are not realizing very much larger profits.

I want to congratulate the Corn Exchange Bank, Rural Progress Association, The Philadelphia Society for Promoting Agriculture and everybody who has had any part in this meeting, on the idea of having a get-together conference in Philadelphia. I am glad that the framers of the programme have barred out all questions relating to production. It is high time that the producers of this district and the consumers in our cities get together for the purpose of discussing market problems.

There are certain factors which contribute largely to the high cost of food, and I shall view this question largely from the standpoint of one who lives in the country and who has had experience in producing for city markets. In the first place, those of us who live in the country believe that too many people in the city are making a living off the farmer. We 
believe there are too many middlemen. We believe that fewer middlemen could handle our foodstuffs and make a good living, perhaps a better living than the farmers who produce them.

A few years ago I spent some time in the Kalamazoo celery district. I found that a dozen plants of celery were delivered at the packing house in Kalamazoo for ten cents. I found that these packers were shipping to State College, and upon inquiry at State College I learned that the retail price was five to ten cents a plant. In other words, a single plant at State College was worth as much as a dozen plants at Kalamazoo. Many illustrations might be given to show that products often pass through the hands of three or four men before they reach the consumer. This condition should be corrected.

There are transportation difficulties and many of them are hard to solve. We must have better country roads everywhere in Pennsylvania before the farmer can haul his produce to market or to the shipping station in first-class condition.

Thousands of bushels of apples went to waste under the trees in Center County last fall. I presume one of the main reasons for this loss is the fact that the farmers of Center County are not organized. The growers who had a large crop were not acquainted with Philadelphia dealers. Very few of the farmers had sufficient apples to make up carload lots and no one was sufficiently interested to collect the apples and make shipments in carload lots. In this particular instance, it is readily seen that a city organization, which would have furnished the necessary information to the growers relative to city buyers, and a rural co-operative association, might have made it possible to ship the apples at a profit.

The students of the Department of Horticulture of the Pennsylvania State College have been making some experiments in shipping tomatoes by parcel post. The best cardboard packages available were secured to contain the tomatoes. They have been shipped to Philadelphia as well as to other points in various parts of the country. In very few instances have the tomatoes arrived in good condition. As a rule they have been more or less crushed in shipment and the juice has been oozing out of them when received. This single experiment proves that the present method of handling perishable and easily injured products by parcel post as now managed is unsatisfactory. It indicates that the postal authorities will find it necessary to provide hampers for the handling of farm produce before we can expect satisfactory results.

There is a great diversity of opinion on the various questions relating to storage of farm products. All of us are ready to admit that there must be facilities for storage, both in the country and in the city. Ample storage facilities are essential to the equal distribution of farm products throughout the year. If we do not have liberal storage facilities, farm products will be dumped on the market in great quantities at certain seasons of the year, causing market slumps and depreciation in prices, which are usually 
followed by abnormally high prices. The great need then, so far as storage is concerned, is larger and better regulated houses for both city and country storage.

The question of supply and demand deserves special consideration at this time. We all know that the importation of certain important foodstuffs has increased greatly during the past few years and that our exportation of important food articles has decreased. This is a comparatively new country and yet we are failing to feed our own population. At the present time both corn and beef are being imported from South America; while our own country and our own State of Pennsylvania are pre-eminently adapted to the production of corn and beef. We have hundreds of acres of land in Pennsylvania which are practically nonproductive and which might provide excellent grazing for large numbers of cattle and sheep. The Pennsylvania State College is very much interested in the problem of increased beef production in this state. A large herd of registered beef cattle is maintained at the College with the idea of determining the cost of breeding and raising beef cattle in Pennsylvania. We believe that it is possible for this state to compete successfully with the West, provided the most approved and economical methods are employed.

Both city and farm wastes are enormous. You will notice that I said city as well as farm wastes. We hear a great deal about country wastes. It seems that almost everyone you meet in the city has something to say about the wastes of the country. They declare that the owners of rural properties are not using their lands as they should; that they are not properly conserving soil fertility; that they are not utilizing their crops to the best advantage. Most of our farmers are willing to admit their wastefulness, but we should also take into account in connection with the high cost of living the enormous waste of the cities. How about the milkmen who chase down the city alleys every morning, dozens of them perhaps, when three or four wagons might deliver the milk in the same territory at a very much lower cost? There is also an enormous waste in the delivery of groceries in the city. How about the consumer who 'phones to his grocer and asks for a quarter of a peck of apples or potatoes to be delivered at his residence several miles away? Who pays for this heavy expense? You pay for it, but the farmer gets most of the blame for the high cost of living.

My attention has been called to a vender's wagon which operates in West Philadelphia during the fall and winter season. The wagon is substantially built and tastefully painted, and the team, with brasstrimmed harness, is kept in a city stable. Every morning two men with the team and wagon drive to Dock Street and purchase a load of apples. They then drive to West Philadelphia and the entire day is spent in peddling the load of apples. It is seen at once that the apples must be sold at a very great advance of the price paid on Dock Street in order to 
meet the wages of two men and to meet the expense of keeping the team and wagon in the city livery stable. The consumers who purchase the apples must pay, of course, the excessive cost of distribution, but the apple growers are in no sense to blame for the high cost of apples in West Philadelphia.

Frequently we hear of a consumers' league which is rendering most excellent service in reducing the cost of living. This often means the elimination of a certain number of middlemen. In order to accomplish this it is necessary for residents to be provided with ample and satisfactory storage facilities. Every city residence should have sufficient space to store a barrel of potatoes, a barrel of apples, part of a crate of celery, a basket or two of tomatoes, a barrel of sweet potatoes and other products which are enjoyed by the family. It would then be possible to have shipments made direct from the farm, or perhaps wholesale houses could deliver to the residences without the products going through the hands of several middlemen. This is a thoroughly practical proposition and should receive attention by city consumers. There is no reason why every new house erected in the city should not contain approved storage for the foodstuffs that are used in every home.

There is need of a greater number of rural co-operative associations. We can not expect to realize the best results from either the city or the country man's standpoint until the producers are better organized. Cooperation, however, is impossible in any community unless the people of the community want to co-operate. This is the great trouble in most of the rural sections of Pennsylvania. Our people have not learned the real value of co-operation. There is also need, of course, as previously indicated, of city organizations which may be linked with the country organizations. Our farmers want to know where to sell and the city consumers want to know where to buy. I am well acquainted with many reliable growers of apples in Pennsylvania who would like to do business direct with consumers in Philadelphia. When such growers inquire of my office at State College regarding consumers in Philadelphia who would like to buy direct from the farm, we are unable to give them this information. You see at once the need of city organizations which will link with the country organizations. It seems to me that the function of the city organization will be largely an informational bureau, which will be welcomed by farmers who desire to do business in the city.

There must be increased production in Pennsylvania. The need in order to secure increased production is not more farmers but better farmers. We want more farmers who are able to grow 30 bushels of wheat to the acre instead of 15 bushels. We want more farmers who average 75 bushels of shelled corn to the acre instead of 35 . We want more potato growers who can produce from 200 to 300 bushels of potatoes to the acre instead of 100. We want more poultrymen who are able to produce 150 eggs per year instead of 100 . In other words, better farming on lands now culti- 
vated will materially increase production and also the products might be sold at a lower figure and the profits of the producers will be materially increased.

In this connection it is interesting to note that large numbers of city boys are studying agriculture at the various agricultural colleges of the country. A survey was made last year of the students in the School of Agriculture at the Pennsylvania State College and it was found that 70 out of every 100 boys at State College had entered from towns and cities of the state. In other words, three-fourths of the students studying agriculture at State College are town and city bred boys. This fact is significant and it indicates that there is a real "back-to-the-land" movement in Pennsylvania.

There is need of more economic production in Pennsylvania. Thousands of farmers are spending unnecessary energy in growing their staple crops. The more skilful use of approved machinery will help to solve the labor problem of Pennsylvania farmers. Some farmers are able to grow an acre of corn with 60 hours of human labor; while others spend 160 hours of labor per acre and do not get any better results. It is seen at once that the more skilful use of labor would mean time saved, which might be used in cultivating an additional area or perhaps in rest and recreation. The statement is often made that the farmer is overworked, and this is often the case, although it is frequently due to mismanagement. Uniform distribution is an exceedingly important matter in connection with.Pennsylvania market conditions. It is a very common thing for a certain product to be selling at a very low price in one city and at very satisfactory prices in cities three or four miles away. Co-operative organizations will solve this problem.

The standardization of farm products in the various communities of the state should not be overlooked. This is highly essential to the successful operation of a co-operative association. We need communities which will produce all white or all brown eggs; communities which will grow only two or three varieties of apples; communities which will produce certain garden products or small fruits. Such communities would soon become well known for the high standard of the products placed on the market, and would attract buyers, thus making it unnecessary for the community to seek the best markets. In this connection, regional adaptation is exceedingly important. It would be foolish to attempt to produce apples in a section which-is not adapted to apple culture or the varieties selected. Some of our mountain sections, remote from the railroad, are especially well adapted to animal husbandry: land is cheap, pasture grasses thrive and water is abundant. The stock could be driven on hoof to the nearest shipping point. In the hill sections of the state, less intensive methods of agriculture should be practiced. There is too much of a tendency to plow and cultivate steep hillsides which are subject to washing. These lands should be put into permanent pasture, reseeding as often as may be necessary. 
Our producers of fruits, vegetables and other farm crops should learn how to place the produce on the market in the most attractive condition. There are tricks in all trades and this applies to farming as well as to other industries. The manufacturers of toilet articles, such as shaving soap and powders, would not be able to show a profit in this business if they exercised no more care than many of our farmers when marketing the various foodstuffs. The whole problem of putting up the produce in a more attractive form demands the most careful consideration. I remember the time when all the oatmeal sold in country stores was put up in kegs and barrels. The manufacturers have since learned that it is more convenient and that the oatmeal sells better when put up in attractive packages. An extensive grower of potatoes at Norfolk has learned that he is able to sell his potatoes at a higher price if the hoops around the barrels are painted red. A Long Island strawberry grower claims that he gets two cents more a basket by first placing fancy tissue paper in the basket, which is folded over top of the baskets after they have been filled with berries. A sweet-corn grower of New York has materially increased the price received for sweet-corn by packing in attractive paper cartons.

The problem of placing food at the door of the consumer must be solved very largely through co-operation. There must be co-operation among the farmers of the state. The institution which I represent stands ready to help the farmer in every way that is possible. Our bulletins are sent free to all applicants. The County Agent movement is taking hold and in the course of a few years will probably be organized in every county of the state. There is no more efficient means of taking the College to the farmer. The College proposes to meet the needs of the farmer by furnishing him the best literature on farm topics, by holding Farmers' Weeks and other special meetings, by demonstrations, co-operative experiments, corn clubs and other club service, and by the advice of experts who will visit farms upon request, and by whatever service máy be necessary in order to bring to the attention of our producers the information which is needed for the successful management of farms.

Mrs. Sмiтh: We have about ten minutes. If anyone wants to discuss Dr. Watts' talk, he will be glad to answer any question and give any help the State College can give on any matter having to bear upon his address.

Mrs. D. C. LeEDs: I think the fact that there are not more profits is due to the fact that the farmers as a rule do not think it is necessary to have the chickens picked just right or the fruit packed right. There is the reason the farmer loses.

DR. WATTS: The lady has remarked that the reason the farmers are not more successful in realizing profits is that as a rule they do not realize 
the importance of picking the poultry or putting their products on the market in a proper condition; they feel the people in the city do not demand that. There is therefore need for co-operation along that line.

Mrs. H. M. Garrett: As a farmer, I do not have much to sell, but I found out this thing about the asparagus business: When the stalks are the same size all the way through the bunch, you can get a great deal better price, but when there are smaller stalks in the bunch, they do not get the price. The same way with eggs. If you send eggs of uniform color and size, you can get a better price, but if they are mixed up you do not get the same price. It is just the same with potatoes or apples or anything else that you are apt to sell.

Mrs. Sмгтн: Mr. Critchfield, the secretary of the Pennsylvania Department of Agriculture, is here, and I will call on him to give us a few minutes talk today.

Mr. Critchfield: I think you are taking advantage of my youth. I do not think I can say anything except to express my gratification at being here and to say that I have listened to the address with a great deal of pleasure. I am delighted to be here and glad to see that the people in the cities are waking up and taking an interest in this important question. The farmers want some co-operation along this line, and I am glad to know that the day is coming when they are going to get it. I shall not detain you by any further remarks.

Mr. Calwell: The meeting this afternoon will be held in Witherspoon Hall. All the other meetings of the conference will be held in this same chamber, except on Saturday afternoon, which is a meeting for bankers. All the other meetings are open for the public. The Corn Show is at the Bourse, which is a building which runs from Fourth to Fifth Street between Chestnut and Market. I assure you every one of these meetings will be just as interesting as the one that we have had this morning. Every speaker has been picked out because he represents a definite idea.

[The meeting adjourned until 2 o'clock P. M.] 
Afternoon Session, Thursday, December 4, 1913, 2 o'Clock.

Witherspoon HaLl.

Honorary Chairman, Antonio Sans, Esq., President, Commercial Exchange.

Mr. SANs: It is an honor, ladies and gentlemen, to preside temporarily over this meeting. The honor is tantamount to the pleasurable duty that I am to discharge. In the year 1912, from an acreage of $107,083,000$ we raised $3,124,746,000$ bushels of corn. If the same acreage had been made to produce three bushels more to the acre it would have given us over three bushels per capita of the population of our country.

Agriculture is a subject which ought to be in the minds of every citizen of this country. The present generation may not suffer, but our posterity, unless we take means to increase the production and to educate the people who inhabit the cities in their development and growth, will feel the pinch of poor crops. Our population increases at the rate of over twenty million every decade. It will not be a very long period before we shall have two hundred million inhabitants in this country, instead of one hundred million, or nearly so, that we have today. Think of it, gentlemen! What a subject this is! I think that it is paramount to any that has come before the American people for many and many a year.

In the year 1909 there were landed in the port of Philadelphia about twenty-five thousand immigrants. Of this number, but fifteen hundred went to the country. The rest remained in Philadelphia. Think of it, gentlemen! They remained so as to become consumers. We don't want consumers. We want producers. We want to bring the producers to the point where they can supply the consumers. The effort must be made, be it strenuous or otherwise, to get these people who center in our cities to go to the country, to farms. In order to do that, we must make farming life more easy and pleasurable. There ought to be a movement started to make the farmer comfortable on his own farm through means of entertainment and means of libraries and other means that would make his life an easier one.

The gentlemen who have undertaken this corn show and conference are entitled to our thanks. The present officials and board of directors of the Corn Exchange National Bank are entitled to our sincere thanks for having given momentum to the movement. 
May I refer to an incident which I read in a slip today in a newspaper in the City of Philadelphia stating that a magazine called the Banker Farmer has begun its career as a monthly magazine-this month, I believe. The effort is to establish better relationship between the controllers of the credit of the nation in the interest of those who create and need credit. I think that is a movement in the right direction, but if we, individually, do not put forth all our efforts toward making this movement a success it will avail but little.

I am deeply interested in this movement, gentlemen. The commercial body I represent and over which I have the honor to preside, handles generally corn, wheat, oats, flour and everything that pertains to cereals. There is not any trouble about the marketing. We can take care of that. The steamship lines are adequate, and when they are not, tramp steamers come in and take their place. Our exchange gets information from all over the world, with quotations, and everything is ready to be marketed when we once get it. So the marketing, in my opinion, is not as essential as teaching our agriculturists how to raise more and better products.

I have seen corn at the Philadelphia Exchange today, or rather, at the Corn Show in the Bourse Building, that could not be beat. I have seen ears of corn there that could not be improved upon. There was not the waste of that much space where I could even put the end of a pin in. Not a bit of waste. It was just as full at the head as it was at the end of the ear. That is the thing that tells. That is what we want to encourage. We want to encourage these people to select their seed, and if they plant good seed, outside of weather changes and weather conditions, we are bound to raise good corn.

I do not want to detain you further. I will now turn you over to Mrs. Smith, who will act as permanent chairman. I take pleasure in introducing Mrs. Smith. [Applause.]

Mrs. Sмiтh: The next speaker on the programme is Mr. C. L. Logan, who is in charge of the farm bureau of the Binghamton Chamber of Commerce. Many of you know that this piece of work is undertaken by the Delaware and Lackawanna Railroad, the Chamber of Commerce of Binghamton, the State College of New York, and the Department of Agriculture of the United States; but the pioneer work, so far as is known in this country, is the undertaking of the Chamber of Commerce. The story of the inception of that work and of its present state of progress will be told to you by Mr. Logan. I take pleasure in introducing Mr. Logan, of Binghamton, in charge of the farm bureau of the Chamber of Commerce. [Applause.] 


\title{
CITY TRADE BODIES AND AGRICULTURE.
}

\author{
C. L. Logan, \\ Secretary, Binghamton Chamber of Commerce, Binghamton, N. Y.
}

There cannot be any doubt in the minds of men who have given the question of agricultural conditions in the States any consideration as to the advisibility of making an earnest attempt to improve those conditions and to give the tillers of the soil every encouragement possible to make their yields greater.

We have here a problem which year by year takes on an increased importance, for in it are bound up the prosperity, the happiness, the existence of our nation. The farm is truly the basis of human life; all the vast enterprises of men have their beginnings in the food which the soil supplies, and progress is hampered or accelerated by the forces which decrease or increase agricultural productiveness.

History shows us again and again the truth that a nation's political stability as well as its economic growth is founded upon its soil and the use made of it. It is imperative that our people turn to the lessons of history, study them carefully and seek for remedies to overcome them, for as yet we have not learned to evade them.

Men of vision, particularly those who have studied these lessons, see the peril and warn against it. Guglielmo Ferrero, in a masterly study of the Roman Empire's fall, points this parallel: "In no country is this condition more apparent than in the United States. What nation might more easily be borne along by the marvelous abundance of its treasures? It lacks neither territory, nor capital, nor labor. Yet in no country of Europe are the wails over costliness so loud and so common as in the United States. Why? Because in America the disproportion between the progress of the fields and that of the cities, between that of industries and that of agriculture, is still greater than in Europe."

We have men and women of vision here in America, many of them, who are studying these conditions and helping each in his or her small or large way to solve them. I am not going to attempt to go over the field and name any individuals, but wish to speak to you from the viewpoint and activities of the city business man. The mere fact that you have gathered here in Philadelphia to discuss these conditions shows an awakening on the part of your business man for the need of an intelligent cooperation between the city man and his country brother in meeting the problems of country life and an increasing interest in the possibilities of 
that life. To my mind the fact that our men actively engaged in commercial pursuits are now anxious to study agricultural conditions and help solve the problems there presented, is one of the most helpful signs of the times in which we live. Because I believe, regardless of the splendid work of our Agricultural Department in Washington, and state agricultural departments, and agricultural colleges, and our experimental stations, we need the viewpoint and the initiative of the business man and his co-operation is bound to be very helpful in giving to those various agencies his advice and in carrying to them his enthusiasm in meeting and working out large problems.

Now as to one of the methods lately employed to raise the standard of the business of farming; and right here I wish to say if any of you have an idea that farming is not a business, disabuse yourself of that conception, for the elements that go to make the successful farmer are those found in the life of the successful merchant, professional man or manufacturer.

I presume you wish to have from me a brief résumé of the "Binghamton Idea," not that we were the originators of the Farm Bureau Idea, but so called by the Department in Washington because the Binghamton Chamber of Commerce was the first commercial organization to co-operate with the other agencies in the field and lend its financial and active support.

The Binghamton Chamber of Commerce, like similar organizations, had until two years ago occupied itself with efforts to make Binghamton a better place to live and do business in. To locate new industries, to develop local industries, to assist employers in getting labor, to develop the trade of local merchants, wholesale and retail, to secure cheaper and better transportation facilities; all with the object of making Binghamton a larger and more prosperous city. With this programme we believed our activities complete.

A little over two years ago the secretary of our commercial organization and a few of its members began to realize the importance of developing the territory tributary to Binghamton. Only the most casual observation was necessary to convince us the organization was neglecting the most important industry upon which the prosperity of Binghamton depended - the industry of farming, which gave employment to more people in the territory tributary to Binghamton than any other industry or group of industries in the city, and needed our careful consideration.

Upon investigation one of the appalling conditions discovered was the fact that the population of the entire section, exclusive of the cities and growing villages, was less in 1895 than its recorded population in 1865 . To a commercial secretary nothing is so serious, nothing counts so much as population.

It only required a presentation of these facts to the Board of Directors of our Chamber of Commerce to have them authorize the appointment of a special committee to investigate this subject and to report back its findings with recommendations as to the action which should be taken by 
our organization. Only two members of the Binghamton Chamber of Commerce were appointed as members of this committee, a wholesale grocer and a producer of certified milk. Three other members were selected from the adjacent farming sections, men who were known as successful farmers, one a general farmer, one a truck farmer and one a leader in the Grange.

This committee took some time to work out what seemed to them the best solution of the problems presented. This committee found a great need of, first, an application of sound business methods; second, a more general use of the practical results of scientific experimentation. They found much work already being done in the field by the U. S. Department of Agriculture, our state department, our agricultural colleges and experimental stations. In some instances duplication of work was evident and in nearly all instances the field men were attempting to cover four, five or more counties and it was clearly evident it was impossible for one man to do efficient work unless his territory was restricted so he might get in personal touch with the man tilling the soil,

One of the first things which suggested itself to the committee was the establishment of a demonstration farm. It was found at this time the Lackawanna Railroad was thinking of establishing such a farm along its lines. We immediately got in touch with the Lackawanna people and the two organizations co-operating went so far as to get options on several farms near Binghamton which could be used for such purposes. When the committee had a meeting with Prof. W. J. Spillman, then and now in charge of the office of Farm Management, Bureau of Plant Industry, Washington, Prof. Spillman discouraged the demonstration farm idea because it had not given the results for which it was operated, except in a few instances. Many would not even come to see the farm, a large majority of those who did would say, "If I had the money of the government, the state or the railroad I could accomplish as good results." Instead of encouraging them with possibilities of greater attainments, they went away discouraged by their own handicaps, feeling the things necessary for their success were out of reach.

Then too each farming community already has its demonstration farm because of the successful operation by some individual.

At this point the committee concluded to attempt to interest all the agencies working in the field or interested in the work to co-operate with the Binghamton Chamber of Commerce with a view of having its farm bureau considered the local agency through which all the other bodies would work. This plan met with an enthusiastic reception from the officials of all these various agencies. Secretary Wilson, then the head of the Department of Agriculture, said, "We have spent years in inaugurating campaigns of education, frequently entering territories where our efforts were not welcomed by the farmers whom we aimed to assist. It is indeed most encouraging to have a community come to us for our co-operation." We now know a large number of people interested vitally in country life 
problems who believe this plan the most effective ever devised, inasmuch as it advances the local interest through its work and financial support.

The next move was for the various bodies interested to sign an agreement covering the objects and policy of the work and the financial share of each necessary to carry it on. To quote from the agreement:

"The object is to undertake propaganda work in the agricultural district in the vicinity of Binghamton, N. Y.; to make an agricultural survey of the territory; study the farmer's problems, find their solution by a study of the practices of successful farmers; study the relations of types of farming to local conditions of soil, climate, markets, etc. To demonstrate systems of managements used by successful farmers in the district and conduct experiments with the farmers, educational work through the media of institutes, etc., advising with the farmers individually and otherwise as to the best methods, crops, cropping systems, stock, labor, tools and other equipment."

Shortly after signing of the agreement an agent was appointed to take charge of the work, and took up his duties March 20, 1911. Since that time the work has been going on effectively and quietly. In the three years we have not revolutionized the conditions as found in the beginning, but we have accomplished many things for the betterment of country life in our section, and we are arousing an enthusiasm as to the possibilities of agriculture which is bound to make its force felt in the future. We have never had the idea we could turn over the old prejudices or tendencies, or change the lines of thought, operation and management in one year, three years or five, but we have felt by steadily following certain lines of work we would eventually get the impression in the mind of the man whom we wished to reach, of a real enthusiasm for his work and its possibilities for himself, his family and their children.

We are today beginning to see some of these impressions taking hold. We can see general evidences along certain lines of better management, many evidences of individual co-operation which have been successful. Our merchants in the city, especially those dealing directly with the farmer, have already felt the new force, all showing the effectiveness of the work.

We have now twenty counties in New York State with Farm Bureau Agents in the field, all under the able direction of Mr. Lloyd S. Tenny, State Leader. These organizations are financed in different ways and until the present the work too has followed different lines, the local conditions sometimes making this necessary; and on the other hand the office of Farm Management and the State Leader have been groping to a certain extent to find the most efficient methods for the farm agent to follow.

In the beginning our local agent's salary and expenses were paid by the U. S. Government, the Lackawanna Railroad and the Binghamton Chamber of Commerce. These three bodies were the active signers of the original agreement, the New York State Department of Agriculture and the Agricultural College, Ithaca, agreeing to co-operate whenever 
possible in advancing the work. In 1912 the County of Broome appropriated $\$ 1,000$ for the work and this year the State Department of Agriculture contributed, so we now have five agencies actively helping to carry on the work. The Chamber of Commerce receives all moneys and pays out same on vouchers, which are regularly audited and the books or accounts are at all times ready for the inspection of any of the interested parties to the agreement. The office of Farm Management has charge of the man in the field and he is directly supervised by a State Leader.

You will notice in our local organization the farmer was not represented in the agreement by any organization. Largely through the experience and advice of our State Leader we now see this is a mistake and early in November called a meeting of farmers to perfect such an organization among themselves which would become a party to the agreement and have a representation on the Farm Bureau Committee. Such an organization was perfected and, while small at present, we believe it will grow rapidly and become a vital force in the work. I have a copy of the constitution and by-laws of the Farmers' Organization with me for any one to look over who may be interested.

It took our Chamber of Commerce five years to arouse a genuine widespread enthusiasm among its members, the business men of Binghamton, to a point where they are willing not only to dig down into their pockets for money, but to give very liberally of their time in helping develop a greater and more prosperous city.

When we started the conditions were not more discouraging than those confronting us in the work of our Farm Bureau. We are hopeful of arousing the same widespread enthusiasm over its work and opportunities among the farmers that we have succeeded in arousing among our own members. Indications are multiplying; this enthusiasm is gaining a strong foothold in our county.

In the end we will have a city of wide-awake, aggressive and progressive business men, and Binghamton will be the center of a farming community of wide-awake, aggressive and progressive farmers. This result will not be accomplished by the city man alone, nor by the farmers alone, but the result of both working together for the greater prosperity of the whole community.

Mrs. Smith: I think you will all agree that this sort of movement between the city and country is ideal, and it is a movement that is undoubtedly given force as the city dweller suffers more and more from the high cost of living.

I am very glad that Mr. Logan presented to you in a very clear form exactly what they have done and the way they do it. To me it was an interesting history and a story that was very dramatic-very dramatic in the way they discovered where they were falling behind and the way they set about remedying it. I want to say this is only an 
instance, and we have duplications of these instances all over the world, for no city can afford to go along in its career without taking an account of stock as to its environment and find out whether the situation is really a wholesome one or not, or whether the farmers who supply the city are in a discouraged or encouraged state of mind; whether the market conditions are what they are cracked up to be; whether there is something the matter; if there is dissatisfaction, where is the dissatisfaction. Where there is unquietness, naturally the inference is that there is some influence at work that is not wholesome, either for the producer or the consumer. That is the sort of thing Binghamton inculcated, and it is for the good of everybody concerned, and I thought in presenting to you the work of this Binghamton Chamber of Commerce we could not have possibly offered you anything that was more to the point as regards the present situation than that. The thought that lies back of this afternoon's programme is, first of all, the marketing. Marketing is put down as the general topic, and we are going to have some people here with us who will solve the question of marketing, and we have with us this afternoon two experts on the egg question and the poultry question. As we all know, there are no two questions today that occupy the public more.

We have picked out to illustrate the question of the handling of eggs and the marketing of eggs a young man who is in charge of the market bureau started by Cornell University to benefit the farmer, and which has given great satisfaction to the local farmers. Mr. Benjamin will tell you what they have done, how they do it and what conditions they found, and he will follow his talk this afternoon by showing a few slides this evening, as the lantern is not here now. The lantern, unfortunately, is at City Hall, and he will have a chance this evening to show you some slides to illustrate his talk. I take pleasure in introducing to you Mr. E. W. Benjamin, of Cornell University, the head of the marketing department, who will talk on "Problems in Marketing Eggs." [Applause.] 


\section{PROBLEMS IN MARKETING EGGS.}

\section{Mr. E. W. Benjamin,}

Department of Poultry Husbandry, College of Agriculture, Cornell University.

Mr. Benjamin: Madam Chairman, Ladies and Gentlemen: First I might say I do not know how to express my appreciation for this opportunity of being here today. I am very glad to be here at a conference of this sort, as this conference, it seems to me, is one which will really aid in bringing the important questions of distributing food products to a focus. It marks a very distinct stepping stone in improving many of the chief faults in our systems of food handling and in connecting the producer with the consumer in a better way than we have been connecting them in the past.

My subject is "Problems in Marketing Eggs." I consider that the problem in marketing eggs. is the problem of making both the consumer and the producer better satisfied. One is just as important as the other. Both the consumer and the producer should be better satisfied than they are at present if we are going to in any way solve this problem of marketing eggs, or as a matter of fact, the problem of marketing any food product, since the principles involved are always essentially the same.

I presume that eggs are thought of about as much as anything at this time of the year. It happens once a year that everybody thinks that eggs are away out of sight and it appears that there is a great deal more trickery with the marketing of eggs than exists in the marketing of other products. Regularly every year, at this season and a few weeks earlier, everybody's hens have stopped laying. If you go out into the country and try to get some fresh eggs, you will see how hard it is to get them. The hens have stopped laying entirely and the farmers have not seen an egg for a long, long time. We are now just beginning to get fresh eggs, and in two or three weeks the number of fresh eggs will increase and the price will gradually go down. Just at this time, however, it is almost impossible to get fresh eggs from the American farming communities. Some who specialize in poultry farming do have eggs the year round and can afford to properly take care of the birds for the purpose of supplying a few consumers, but it is almost impossible to get fresh eggs on the general market at this time of the year. As a substitute we have the cold storage product or product that has been held for a varying length of time, coming in to supply that need.

In making both the producer and consumer better satisfied, I might enumerate the things that the consumer wants, and the first one of these 
is lower price. No consumer wants to have the prices any higher than they are at present. What they want is a lower price for the product. Along with lower prices, the consumers want better quality. They want to pay less for better goods, and along with that they want to have the marketing at least as convenient as it is at present. These are the three things they want: lower prices, better quality and convenience.

The producers, on the other hand, are looking forward to receiving higher prices, with the maximum degree of convenience. They are looking forward to having higher prices, while the consumers are looking forward to having lower prices. The consumer also wants better quality, and both want to have things just as convenient as they are now, or more convenient if possible. These then are the factors that we have to consider.

The methods of attacking this problem which are open to the consumer-and I think most of the people to whom I am speaking today are consumers or are interested in the consumer's end of the game-are, first, encourage the farmers to improve the method of producing the product, both by lowering its cost and improving its quality. If the farmers could produce their products at less cost and also produce better products, then they would really be getting better pay for their labor after all. If they really did not get any more per dozen, but they produced more dozens of eggs at the same price per dozen, they would be able to make more profit than now.

Thus, one method of attack is simply by improved methods of production. You can talk a long time about improved methods of production. You can go out among the farmers and tell them that they ought to do this and ought to do that, and it is the easiest thing in the world to tell them how much better you could do if you owned the place, but you have never been in their place probably and cannot appreciate their viewpoint. If many of us were to put ourselves in their place, possibly we could talk more sensibly than we can now, and this is probably the reason that it is so commonly said that "you can talk and talk and talk to the farmer, and yet when you go back you will find that the farmers have not changed their method a bit." No matter what you tell them, they will not change their methods, because their methods are better, they say, and they have been trying it for a long time. There is naturally competition among farmers, and we would indeed expect that in any certain community after generations of experiments, very good methods of farming have already been adopted. These farmers have been doing the same thing for many years, and have adopted just exactly what they have thought to be the best methods.

We have found incidentally that the only way to really change the farmer's methods of production, the only way to improve them rapidly, is to actually show the farmer that there is a better method, if there is any such better method-actually show them that there is a better 
method, either by doing it ourselves or by getting them to try it. So what I am going to speak of this afternoon particularly will be the co-operative organization that we have started at Ithaca, in connection with the New York State College of Agriculture, by means of which we have to some extent shown farmers better methods of marketing their products, and we have hoped not only to show them that, but also to show them how to produce better products than they were producing, and the results have been phenomenal.

We have been talking to the farmers around Ithaca for a long, long time-sent speakers out to them, and they have not changed much. Then we started this organization and attempted to handle the products for the farmers, and showed them that we could get more money for their fresh eggs than we could for their stale eggs. Previously we had told them that fresh eggs were worth more than stale eggs, but that did not make any difference when they could get as much for a stale egg as they could for a fresh egg; but when we took their eggs and returned to them a check at the rate of sixty cents a dozen for their fresh eggs and only forty cents for eggs which they had held over from the week before, then the next week nearly every egg received was fresh. That is the way to get them interested and that is what we have been endeavoring to do around Ithaca.

I will pass on, first, with another method of attack, and then return more definitely to this co-operative association. After improving the method of the production of the products, we have then to deal with the method of the distribution of these products, or carrying of the products, just as we find them, from the farmer to the consumer. I will be able to take this up a little better with the lantern slides, but I might say that the closer we can get the consumer to the producer, the better off they both are. When we have the producer over here and the consumer away over there, we are not going to improve the quality of these eggs and this produce by carrying them from this producer over to the consumer. The farther off the consumer is, the poorer the quality will be by the time the produce reaches him. We also know that we are not going to carry this produce over there for nothing. We have got to charge something for that work. The farther off a consumer is the more it is going to cost to get the produce to him. If we can get the consumer closer to the producer in any possible way, the better will be the quality of the produce which the consumer will receive and the lower will be the price that he will have to pay for it. That, on the face of it, seems like cutting out the middleman. We have heard a lot about that, but I do not intend to infer that we should in any way cut out all the middlemen. We think, in a good many cases, there are more middlemen than are desirable, but under most conditions the middleman is necessary. If the producers try to send their products to the consumers by parcel post or by any other direct means, they would get into a very complicated proposition. Every 
producer would have to deal with many consumers and every consumer would have to deal with several producers. There is a method and means of organization whereby the consumer shall deal with a man who understands their needs and their wants, and then that man shall deal with the producers. I shall be able to show this method better with the lantern slides tonight.

We believe, as a rule, that some man is needed between this producer, who just specializes in producing the best stuff he can in the cheapest way, and this consumer, on the other hand, who should endeavor to buy more economically than he does at the present time.

So we go on to the third phase of this question, which is a matter of importance, and that is the buying of the product. That can be improved. We can make an improvement in the methods of production, methods of distribution and also improve the methods of buying on the part of the consumers. The high cost of living is undoubtedly due to a great extent to the extravagant wants of the consumers, who are becoming more and more exacting all the time, and the housewife's problem is that of learning to buy more economically. They do not buy the very cheapest grade of eggs which they can get and still have eggs which are suitable for their various purposes. The housewives do not have to buy strictly fresh white eggs to make cake with. They do not have to buy the very best eggs for that purpose. You do not have to have white eggs instead of brown eggs. Brown eggs are just as good as white eggs. The difference in price between white eggs and brown eggs in the New York market is not based on the relative quality of these eggs, as a rule, but is based on the foolish tastes of the consumers who buy those eggs and who are willing to pay more for the white eggs; consequently there is more of a demand for the white eggs. There is no difference in the interior quality of a white egg and that of a brown egg. The consumers of New York and Philadelphia should use brown eggs instead of white eggs if they want to lower the cost of living. It is said among cold storage men that brown eggs even keep better in cold storage than white eggs. That is supposed to be due, I believe, to some difference in the shell, but I have never been able to find out just why a brown egg keeps better than a white egg. If brown eggs are worth more than white eggs for storage, then they should be higher in price than white eggs, but that is not the case at this time. It is just the other way; white eggs are higher and the consumers have the idea that the higher price for white eggs indicates that the white egg is better. That is especially so in New York City, due to the fact that most of the large farms around New York City have White Leghorns and other Mediterranean breeds which produce white eggs, while the majority of the brown eggs come from the Middle West and from the South, where the farmers have more of the larger general purpose breeds. In Boston the brown egg usually brings more than the white egg, and this condition is caused by a reversal of the conditions around New York City. 
Now, I have given you in substance the methods that we have followed in attacking this problem of improving conditions in the vicinity of Ithaca, and I will go into it more fully later in connection with what we have done. If any one has any questions to ask relating to this, I will be glad to have you come back at me as soon as I am through.

The idea of organizing a co-operative association in the vicinity of the College of Agriculture occurred to us, especially after we had endeavored to connect up the individual farmers with the consumers in the larger cities. Very few producers in the vicinity of Ithaca had any idea of how to get connected with the larger consumer or with the city consumer. I do not know of any who sold direct to the city consumers. I went down to New York, went around visiting the purchasing agents of many of the large hotels. I must have visited twenty-five or thirty of the larger hotels and retail stores. I also visited Mrs. Heath of the Housewife's League, and tried to get in touch with all the larger consumers that I could, and I told them that we were planning to connect them up with some producers. The first trouble with our plan seemed to be that we did not have any single farmer large enough to produce enough eggs to supply any single customer. The large consumers wanted to get a large number of eggs, and they wanted to be able to depend on that source for a regular supply. Most of them got eggs from some wholesale dealer, who could furnish a few dozens or several cases per day. In other words, they were in the habit of ordering daily just what they wanted. That was not only the case with one, but seemed to be very common, and I could see that we had to offer big inducements to get them away from their common dealers in the immediate neighborhood and influence them to get their eggs direct from the producers, in spite of the fact that this method would probably enable them to get better eggs.

So I went back to Ithaca with the idea of getting in touch with bigger farmers, better products, and getting a lot of the producers together. It was with that idea that we started in.

I went back and we talked it over with the farmers of the neighborhood and we tried to get the farmers to organize with the idea of getting enough eggs so we could get a certain trade established and to hold this trade by supplying it the year round; during the winter when the consumers were unable to get eggs anywhere else, as well as during the spring and summer when eggs were very plentiful. We immediately started to organize these farmers. They all realized that it would be a good thing to do and yet nobody was ready to make the start. They did not want to go into anything unless their neighbors did. So we set a certain day about the middle of February and told them that from that time on they might bring their eggs to the College, and the College would look after the marketing, and then would return to them all that the eggs were sold for, less the actual expense the College had undergone in handling them. This expense included every operation. We did not charge for 
our energy spent as promoters, but we charged for all the actual expense of marketing the eggs. We hired special assistants to do the candling and grading of the eggs. We started out by receiving only a few cases the first week and we shipped those eggs, first, to a commission man. We did not have any special trade established. This commission man paid us a cent above top wholesale quotations. We sent all the eggs that were brought to us, the best as well as all other grades, and then as soon as returns were received, we in turn forwarded to the farmers our checks, simply taking out so much per dozen for handling, which amounted to approximately two cents per dozen, and the farmers were getting one and one-half or two cents per dozen more than they had been receiving before. Gradually the farmers began to bring in more eggs and we were able to establish a trade with some New York hotels for the best grades. This hotel trade gave us much better returns for our best grades of eggs than the wholesalers could, and so from this time on our markets were considerably improved. This last fall we have had difficulty again in getting eggs enough to supply the trade, because the farmers were not in the habit of trying to produce many eggs during the winter, because the price had never risen over about thirty-five cents per dozen, and they could not afford to produce eggs for that. We had to start sending out wagons to collect eggs from the farmers, and it was a difficult proposition to find them, but we did find a few and the prices received were away beyond what the individual producers could have obtained by themselves for their small lots. The last returns paid to the farmers were at the rate of about sixty-seven cents per dozen for the fancy white eggs. The brown eggs were fifteen cents less per dozen. Fifteen cents per dozen difference between white and brown eggs. Of course, it is up to the farmer to produce white eggs if he can get more for white eggs than he can for brown eggs, but the consumer, on the other hand, who uses white eggs pays more than she needs to for the desired degree of freshness. Here are two counterbalancing forces. If we turn to the consumer we should advise him to use brown eggs, and if we turn to the producer we tell him to produce white eggs and he will get a higher price for them, and eventually the prices of brown and white eggs will be more nearly equal.

Conservatively speaking, the farmers who cared for their products were able to average about fifty cents per dozen for their eggs, white or brown, while last year these same farmers during the same season of the year were not getting more than thirty or thirty-five cents for their eggs. This year eggs are about five cents higher than they were last year, but this fact comes far from offsetting the advantage of organization. Next spring, if we get for the farmers two cents more per dozen than they. could otherwise have obtained, we can call our work very successful.

The organization is not binding on the farmers at the present time. We are simply holding the farmers by reason of the benefits which they get from the organization. We do not ask them to become members yet, 
but we expect to get everything definitely organized in due time. It is not much use asking farmers to become members of an organization from which they are deriving no benefit, so we are just asking them to bring in their eggs or send them if they want to. If they bring in their eggs, we try to sell them. If they don't want to bring in any eggs and are not interested, we don't care.

As further information relative to our work, I will read now from a recent report from the Poultry Department to the Director of the College:

"The co-operative marketing association project, organized during the year and which has now been in operation about seven months, developed more satisfactorily even than we had anticipated. The department has supervised the organization of the Ithaca Producers' Association. This project is under the immediate supervision of Mr. E. W. Benjamin, who reports that the association has been handling the poultry and eggs produced by 168 patrons within a radius of approximately ten miles of Ithaca. The number of eggs handled by the association for its

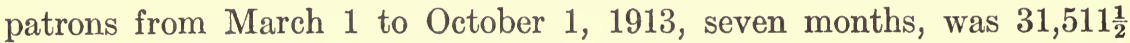
dozens, equal to 1,050 cases of thirty dozens each, or approximately two and one-half car loads. The amount of poultry handled during the same time was $6,538 \frac{1}{3} \mathrm{lbs}$., or approximately three and one-quarter tons. The total net returns to the patrons were $\$ 7,753.86$. It is estimated that the patrons have been aided in receiving about three cents per dozen more for their eggs and two cents per pound more for their poultry than they would otherwise have been likely to receive; or, expressed in money value, the patrons have received about $\$ 130$ more for their poultry and $\$ 945$ more for their eggs, or a total of $\$ 1,076$ more than they would otherwise have been able to secure by the usual methods. This increase in profits is due, primarily, to greater care in testing, grading and packing, which has resulted in higher prices being received. The educational value of the project is a stimulus to greater production of a better quality of poultry and eggs. More systematic care and accounting is of even greater advantage to the patrons than the increase in their net profits, due to the sales. The project is of benefit not only to the producer, but also to the consumer, and has resulted in securing close co-operation with persons who otherwise might not be in touch with the college."

This educational feature is one of our strong points. At certain intervals we send out circulars to these farmers telling them how to market their products, at what particular time to sell; how to pack their poultry when they bring it up for sale; how to keep their eggs; that is, in a cool or rather moist place; not to allow the eggs to heat nor to getchilled; not to allow the male birds to be with the laying hens, and many other timely suggestions.

The fertile egg is probably one of the greatest troubles we have at the present time in the handling of market eggs. The germ of the fertile egg will start to develop at a temperature of about $72^{\circ}$ Fahrenheit, and if 
kept for a very long period, it will rapidly decompose. The fertile egg is very undesirable for use as a market product. We tell the farmers of these things and help them to decide which breed to pick out, if they are going to enlarge their poultry business, and they appreciate the information. They realize that if they do not produce the right sort of products, they cannot demand a high price for it.

We believe that the association is working on a fairly efficient basis. Of course, just as soon as we have a co-operative organization, there is a tendency for the operator to use less efficient methods than he will if it is his own private enterprise.

One of the great drawbacks in getting an organization started is that when many men are banded together, responsibility is liable to rest upon no one person and the efforts become slackened. In my work with this association I have found that the margin of profit between the producer and the wholesaler is usually very small. There is not such a large margin of profit as is often represented. There are many producers who have enough eggs so that the benefits of co-operation are very slight and they are able to send their eggs direct to the consumers. They have enough products to send direct to the hotel or large consumer, and it is not our purpose to handle them now. We just handle the products from the smaller producer, and if he does not have enough to send to us direct we collect them with many others and thereby save the countless delays occurring when the eggs pass through the ordinary "huckster-country store" route. The more producers who furnish products and the more produce they can furnish, the less will be the cost of handling and the lower will be the cost of this produce to the consumer.

My time is limited, and I will be able to tell you more about this problem, with the lantern slides which will be shown this evening.

Mr. Felix Albright: I would like to ask the rate of charge for a day's board at the hotel that pays sixty-seven cents for eggs. What would they charge me a day for a day's board at that hotel?

Mr. Benjamin: Of course, these eggs go to one of the largest hotels in the city.

Mr. Albright: I would like to know the cost of board for one day.

Mr. Benjamin: Of course, the hotel furnishes other services than that required in the preparation of eggs. While the labor itself may be nominal, there is a lot of other things necessary in a hotel in order to satisfy their customers.

Mr. Herbert P. Brown: I would like to ask why there is this difference in the price of eggs. You say the farmers got thirty cents last year, and this year they got about sixty cents. What made that difference so much as that? 
Mr. Benjamin: The difference is due to the fact that last year the farmers sold their eggs to country peddlers, who went around and who picked up the country stock, and by the time it got to the wholesale man eggs were not worth any more than that. The farmer does not think his eggs are better this year than last year. He does not believe in holding his eggs, and disposing of them promptly; they are of a better quality, and that is the reason they are getting greater prices. The improved manner of distribution in getting these eggs from the farmer to the market is the reason he is getting more.

Mr. Brown: Is it a fact that in Boston brown eggs are worth more than white eggs, and a man there pays as much for brown eggs as a New Yorker pays for white eggs?

Mr. Benjamin: That is a fact; he pays about five cents more for brown eggs than for white eggs. That is due to the fact that around Boston they have more hens laying brown eggs. The product in the immediate vicinity of Boston is usually brown eggs.

Mr. John J. Macdonald: I was very much interested in the address of Mr. Benjamin, and he brought out something I am very much interested in, and that is the middleman. I happen to be one of those who have been robbing the people for the last thirty or forty years, according to the newspapers. I am glad to see the Agricultural Department of New York is back of our plan and standing up for us. Another thought has been brought to our minds and that is, that the agricultural colleges of New York are authorizing their customers to ask sixty-six cents a dozen for eggs, and Mr. Benjamin says he was down in New York and consulted with Mrs. Heath. The other day I saw an interview in the World of New York, in which she said she only got thirty cents a dozen for eggs. There is some discrepancy here somewhere. Mr. Benjamin has made the best argument for the middleman I have ever heard made. The middleman will be here with us when you and I are in our graves. You can't do without him. I will say right now that this thing has gone on until the people begin to believe that the man between was getting eight or ten or fifteen cents a dozen profit on eggs, and now we have Mr. Benjamin declaring that the farmer gets it all.

Mr. Benjamin: I think, perhaps, you may have misunderstood me. I told you, in the first place, that I believe the middleman is necessary to connect up the producer with the consumer. What we have done is simply to get the producers together, and in this particular we are in the shape of middlemen. These people are not large producers, but we get enough together in order to be able to send enough eggs direct to the wholesale dealer or-large consumer.

Mrs. Sмith: I do not want to interfere with this discussion, but the next speaker on this afternoon's programme will speak on the question of 
poultry, and that is something we are very much interested in. I am not as personally acquainted with him as with 'Mr. Benjamin, but I have known so much of Mr. Opperman, and his wonderful work, and I have read so much of his work in the country, that I consider him one of the greatest specialists on the subject he is going to talk about. He lives at Three Oaks Villa, Berwyn, Md., and there isn't a question, from the number of notches there should be in a White Leghorn's comb to the kind of eggs that a White Leghorn or Plymouth Rock should produce, that he can't answer. It is a question that he is familiar with and I take pleasure in introducing to you Mr. Charles L. Opperman, who will now speak to us. [Applause.] 


\title{
PROBLEMS IN MARKETING EGGS.
}

\section{Charles L. Opperman,}

\author{
Berwyn, Md.
}

\section{Madam Chairman, Members of the Conference, Ladies and Gentlemen:} I fear that your chairman has given me a reputation which I may find rather hard to fulfill. If I knew all that she claimed for me, I am sure I could entertain you in a most satisfactory manner. However, even though I cannot promise to furnish all the information she claimed, I shall attempt to leave with you a few of the vital points connected with the handling of the nation's egg supply.

Before developing this subject I wish to add just a few words to what Prof. Benjamin has had to say concerning a co-operative plan of marketing eggs now in operation at Cornell University. Prof. Benjamin has very ably discussed this phase of marketing eggs and I may say, if he will permit me, that he has presented the strongest argument I have recently heard in favor of the middleman. We have heard so much during the past few weeks about the terrible middleman and the cold-storage robbers that I am really almost afraid to express myself on the subject. I think, however, that Prof. Benjamin's remarks open the way for me to say a word or two about these much berated and little understood business men. To my mind they are as much needed in the handling of eggs and produce as the producer himself. Without the middleman in one form or another, be it a co-operative concern or commission house, it would be practically impossible to properly prepare eggs and many other products of the farm in such a way as to be presentable to the buying public and without the cold-storage man I do not dare to suggest to you how much you would now be paying for fresh eggs and many of the other very important commodities of life.

The middleman and the cold-storage man are not, in the main, the ones who are responsible for the present high price of eggs. If a few of the women who are making such a to-do over this matter, would look into the proposition more closely they would find that the retailer and not the parties now being condemned, are in fact the ones who are robbing the public pocketbook. By way of illustration, permit me to say that I know of several large grocers who make a point of storing eggs in the spring and then withdrawing them the next fall and winter as fast as their trade demands. These men, as well as other grocers, who buy from large egg dealers having holdings in storage houses, take eight or ten cases of eggs, which have probably been purchased around twenty-five 
cents, and grade them over to supply the requirements of their trade. In other words, in the hands of these men, ten cases of storage eggs may produce as high as five cases of nearby henneries retailing anywhere from fifty to seventy-five cents a dozen, two or three cases of so-called fresh eggs selling at a slightly lower price than the former and finally, what are left are then classed as storage eggs. Is it any wonder that the good housewife of the country objects to buying storage eggs and demands what she is led to believe is the fresh product? If this conference and organization wants a problem worthy of its consideration I would like to suggest that they do everything in their power to see to it that storage eggs are sold as storage eggs.

Returning to the co-operative idea which has been so well discussed by my colleague, I want to say that my experience along this line has been that the personal element which naturally enters into these organizations has been the greatest setback to their progress. I firmly believe, however, that the idea is right and that ultimately the vast majority of our agricultural products will be handled along some such lines. To cite an instance of the great disadvantage of the personal element, let me tell you something about the greatest co-operative state in our union. Minnesota has somewhere in the neighborhood of 900 co-operative creameries and she also has several large private centralizing concerns. Naturally these centralizers are after all the business they can get and in order to undermine the co-operative associations, in which they know this personal greed for gain is bound to help them, they conduct a station in the town where there is a co-operative association and boost the price of butter fat until those managing the co-operative concern can no longer compete with them. The result you probably already know. The members of the co-operative organization, as soon as the price of the centralizers exceeds that of their own office, immediately become suspicious of their manager and take their products to the competitive house. After the co-operative concern is completely disorganized the centralizer, who has now secured the bulk of the business, gradually reduces the price until it again strikes a normal level. This may not be the exact plan that is always followed in such cases, but from my observation it presents a fairly accurate picture of the usual situation. While I regret to say so it is nevertheless true that there seems to be no limit to which American business may stoop today in order to crush out a competitor.

I again repeat that the co-operative idea is a splendid medium through which the farmer or producer may buy or sell his products. To be successful, however, it is absolutely essential that the men in charge be competent, command the respect and confidence of patrons and have at heart the welfare and betterment of the community in which they are operating. A great many of the failures of the various co-operative organizations can be traced to the fact that the men in charge of them have little or no knowledge concerning the handling and selling of the 
products in which they deal. Too often a community becomes enthused over the co-operative idea and proceeds at once to perfect an organization, elect officers and formulate rules and regulations with little or no regard as to the fitness of the various people assigned to different branches of the work, to buy, grade, pack and sell the eggs or other commodities which they may propose to handle. There can be but one result to such methods and that, as you know, is failure. The broker, commission man or business man in the city stand but little chance of being successful today unless they thoroughly understand every detail of the business with which they are connected and this applies equally as well to the officers in charge of a co-operative association. Not only must the officers be competent and proficient, but it is of vital importance that the patrons of a co-operative association have implicit confidence in their officials. This latter thought is to be connected primarily with the prices paid and received for products handled. With our wonderful twentieth century development of mail service, telegraph and rural free delivery, every patron is enabled to procure first-hand information concerning the wholesale market quotations, retail selling prices of practically any product that is produced on the farm and, if he makes good use of this information, there is no reason why he should be misled by competitive quotations which have as their object the undermining and disorganization of the independent co-operative organization. He can tell at a glance whether or not the officers of his particular association are returning to him the proper per cent of profits as manifested by public quotations. If they appear to be doing this, it is only fair to the officers and other members of the association that he consult with them before going over to any competitive buyer who is offering. more remunerative prices. The pursuance of such a policy will, in the main, be conducive to a vigorous, healthy growth of the co-operative idea.

I feel that I should ask your pardon for digressing from the main theme of my talk, for while co-operative organizations are more or less closely affiliated with the general problem of marketing eggs, they are, so to speak, only a drop in the bucket when we consider the enormous quantity of eggs that is consumed each year in the congested centers. In time their influence is bound to be felt, but at present our attention should be directed mainly to the vast problem of properly handling the ordinary farm egg which composes over ninety per cent of the commercial egg trade. Let us then, for a few minutes, direct our attention to this general problem and attempt to ascertain whether or not some methods of procedure may be evolved which will have as their final object the elimination of the present $\$ 45,000,000$ yearly loss in the production, handling and marketing of the nation's egg supply.

In order that we may make pertinent suggestions we must first know something of the present conditions surrounding the commercial egg trade. The production is naturally the first factor which demands our 
attention and knowledge covering this subject must be obtained first hand from the farmer himself. A survey of this field reveals to us shiftless and haphazard methods of management and no particular attention is paid to housing, feeding and breeding. The care and handling of the egg itself, which is the question we are most deeply interested in, appears to be the last consideration of the producer, and as we follow the egg in its journey to the ultimate consumer we shall $\mathrm{I}$ hope realize in a measure the reason for this apparent indifference on the part of the farmer.

The most striking reason for this indifference is to be found in the absurd methods of handling this perishable product, which have been and are still in vogue in many states. Explained in the briefest form, this method calls for the payment of a fixed price, which happens to be current at the time, for each and every dozen of eggs which may be offered for sale, regardless of whether the eggs themselves are good, bad or indifferent. In other words, the only requisite necessary in order to consummate a sale is for each egg to have an intact shell. Under such a system is it any wonder that when John Doe brings a case of clean, fresh eggs to town and receives the same price that his neighbor is paid for rotten eggs, he soon becomes indifferent and cares little or nothing about the quality of future products?

Without a waste of further words, we can sum up the situation with the adage, "Whatsoever a man soweth, that shall he also reap." Egg men, commission men and all others who deal in eggs have only themselves to blame for existing conditions. The standard which they have established has been well lived up to by the farmers. All this, however, is past history and I take it that this conference is mainly interested in suggestions and plans looking to the betterment of existing conditions, therefore let us leave this portion of the problem and consider remedies which may help to alleviate it.

We know without further consideration that methods of production on the farm are anything but what they should be and the first problem then for our attention is the improvement of these conditions. This improvement may be accomplished through our agricultural colleges and experiment stations with the co-operation of such organizations as we are now participating in. The colleges and experiment stations are doing everything in their power to help along these lines, but it will not be until the city business man, who makes his money by handling eggs, puts his shoulder to the wheel and helps by inaugurating progressive, common sense methods of buying eggs that we may look for substantial progress. The agricultural worker may talk higher quality eggs until he is black in the face, it will have little effect until the city egg man offers dollars and cents inducement for the producers of the same. Let him also help in disseminating knowledge concerning better methods of housing, feeding, rearing and breeding poultry. Elementary knowledge is what is needed and not dope about the 250-egg hen. Let us first endeavor to improve the 70-egg farm hen before we tackle this rainbow. 
In conjunction with whatever efforts may be made to improve production conditions, there should be tremendous agitation along the line of improved methods of buying. The old case-count system must be discarded and substituted by the quality or loss-off system. The merchant or business man who purchased a bill of goods simply on the guarantee that it would be shipped in a substantial box would be quite likely, as has been the case with the egg man, to get nothing but the box. Just as soon as every egg man insists that all eggs purchased be candled and payment made only for such eggs as are fit for human consumption, are we going to begin to make a marked improvement in the quality of the commercial egg. I am glad to say that this is now being done in several large egg producing states and what we want to do is to continue the good work in the State of Pennsylvania.

The infertile egg is without doubt the most important factor in eliminating the present $\$ 45,000,000$ loss in handling the nation's egg supply. Carefully conducted experiments show that this class of egg is fifty per cent more resistant to unfavorable environmental conditions than the fertile egg. Egg men in Philadelphia and every other city in the United States should take as their slogan the production of infertile eggs. Advocate the elimination of the male birds as soon as the hatching season is over and, presto! the desired result is obtained. At first thought it appears too simple and absurd to be worthy of serious consideration, but I am willing to go on record with the statement that if we can induce the farmer to produce infertile eggs, and leave out all other considerations as to the improvement of general conditions, the present $\$ 45,000,000$ loss will be cut in half.

In closing I leave the following suggestions for your consideration.

See to it that storage eggs are sold as storage eggs.

Encourage the inculcation of better methods of production on the farm.

Demand that the loss-off or quality system of buying replace the present absurd case-count system.

Advocate through whatever channels may be available the production of infertile eggs.

There are many other problems connected with this vast egg industry, but those touched upon will, I think, provide sufficient work for some time to come.

Mr. Herbert P. Brown: Last spring cold-storage men had eggs that were worth only twenty cents right from the farmer.

Mr. Opperman: Yes, I think eggs were only twenty cents, but the great trouble is they do not come to the cold-storage men in the right condition. If they had been sent there direct, I think they would have come out of cold storage just as fine and just as fresh as the day they went in there. Cold storage is a great blessing to humanity, to agricul- 
ture and to humanity, too. Without cold storage we could not buy eggs for a dollar a dozen. We could not do without cold-storage facilities.

Mrs. Smith: We will now be accused of taking sides with the coldstorage people or with holding stock in the cold-storage houses. What we want to do is to get all the information that we can possibly get and to have a square deal for the farmer and a square deal for the consumer. We want to get intelligent light thrown on all these questions, and that is why we are having this conference. I am a farmer myself, and anything about a farm that a farmer's wife has done I believe I have done, and anything that a man has to do about a farm, my husband has done, but nevertheless we have to acknowledge that these charges against the farmer are more or less true. I had a very good farmer's wife on our place last summer and she and I were particularly partners on the chicken question. She came from New York State and she had been under the impression, as Mr. Benjamin mentioned to us, that just any egg was a good egg. On this day in question she brought a basket of eggs and said, "Isn't that splendid; twenty eggs." I said, "Yes, where did you find them?" She said, "Back of the pig pen, and I know they are all perfectly good." I said, "Very well, if they are perfectly good, we will have them for supper." I can only tell you they were unspeakable. That is what happened. The location of the egg basket in the farm kitchen is another item. These are some of the many points that we have got to have information upon. That is what we are here for. Are there any questions 'desired to be asked? I will ask those who are present at this afternoon's meeting to be present tonight, and we can talk to these gentlemen this evening when we meet.

Prof. C. L. King, of the Wharton School, University of Pennsylvania, has a very valuable contribution to make to us on "City-Country Unity Through Market Bureaus." I take pleasure in introducing Prof. King. 


\title{
CITY-COUNTRY UNITY THROUGH MARKET BUREAUS.
}

\author{
Dr. Clyde Lyndon King,
} Political Science, Wharton School, University of Pennsylvania.

\section{Marketing-Its Significance to Farmer and Consumer.}

The cost of living agitation has turned the active minds of many men in all parts of the country and in all trades and occupations to a scrutiny of our existing producing and distributing systems, with a view to finding out what programme may be adopted for the permanent lowering of living costs. These numerous inquiries and studies have clearly established the following general facts as to food products:

1. Production costs will increase.

2. Lower living costs, or even present price levels, are to be maintained if at all only through lowering distribution costs.

Numerous potent factors are making and bid fair to continue to make for increased production costs. The first of these is the fact that population has increased more rapidly than the available food supply. While the population of the United States increased practically thirty millions from 1890 to 1910, the number of cattle in the United States decreased four millions. Such facts as these as to the ratio which the increase in population bears to the food supply meet one at every turn. Moreover, there has been a most significant increase in land values. In the last decade timber lands in the United States have trebled in value, farm lands have doubled in value, and city lands have increased from 20 to 200 per cent. And there is every indication that farm and urban land values will continue to rise; they certainly will so long as they are capitalized, as at present, not only at their productive value, but at their possible earning value in future years when population will be greater and food demands heavier. An increase of 300 per cent in the supply of gold from 1890 to 1910 together with an equal increase in the amount of credit has without doubt caused a lowering in the purchasing power of the dollar. This is not the only factor in higher costs, as some would have us think, but it is one of the factors. And as there is no indication of a change in either gold supply or credit supply, this force also joins in boosting prices. There has likewise been an increase in the cost of raw materials and in labor costs.

All of these factors seem to show that without a doubt production costs will increase. This does not mean, to be sure, that nothing should be done to prevent an undue enhancement of production costs, but it 
does mean that every urban community especially will have to meet a very grave crisis unless food costs can at least be kept at existing levels. The avenue through which this can be done, it appears, is in simplifying and in making more economic and efficient the marketing of food products.

At the present time the consumer pays over two dollars for the same produce for which the farmer receives one dollar. In other words, it costs much more to get our food products from the farmer's gate to the consumer's table than it does to produce them. Such are the facts that have been given winged publicity throughout the past year. The result of the dissemination of information of this character is that certain definite steps are being taken and certain demands are being made by farmer and consumer, transportation and business interests alike, for lowering distribution costs. Let us see what these activities are.

\section{What Are the Farmers Doing?}

The activities of the farmers may be grouped in three classes: (1) their attempts to sell directly through municipal markets, hampers and similar methods; (2) the organization of producers' co-operative societies, and (3) careful scientific studies, assisted by experts, to determine exactly what can be done to return to the farmer a greater proportion of the price paid for food by consumers.

The farmers' attempts to sell directly have led to a demand for open air, curbstone, water-front and terminal wholesale markets. Hon. Cyrus C. Miller, of New York, has done much to show the need and value of a wholesale terminal market which will allow not only direct sales by farmers but also sales to retailers at minimum costs. European cities have long made use of this method, and by keeping in each of their wholesale markets a bonded city-appointed agent who sells at auction any goods consigned to him, have not only reduced distribution costs but also given facilities for the preservation of foods and for quick and inexpensive sales of produce from all countries of the earth. Municipal markets have recently been adopted in many cities throughout the United States, and in certain cities where municipal markets already exist, there is a growing demand for additional ones. The hamper method of sales has, within the last year, received a great deal of careful attention, and, combined with the parcel post, promises results of significant though limited character.

The formation of producers' co-operative associations is deeply significant because it is essential to minimizing and simplifying distribution costs. A prime essential to any trade is that the goods be reliably sorted, properly packed in a way fitted to the trade, and honestly branded and marked. When these three things are performed, the risk that must now be assumed by the wholesaler, jobber and country buyer can largely be eliminated - a risk that has necessarily been expressed in higher prices for consumers. Producers' co-operation not only accomplishes these ends 
but also brings better returns to producers through better business management; eliminates waste and decay by better preservation and more direct shipments; assures economies in marketing and promises better and fresher goods to consumers at prices shaved of unnecessary costs.

Because producers' co-operation does these things, the State of Wisconsin has made it the main duty of its state market bureau to aid the organization of farmers' co-operative societies, and show the farmers how most economically and effectively to sort, pack, grade and market their goods. In May of this year an Office of Markets was established under the national Department of Agriculture to perform a similar service. The work of this newly established office, in the words of its chief, Mr. Charles J. Brand, "will include a study of existing marketing organizations and compilation of laws, state and national, affecting organized production and distribution, and the promotion of new marketing organizations and consumers' leagues, in so far as these activities may be carried on within the authority of the department," with a view to establishing direct dealings with organized producers and to extending more direct sales from producer to consumer.

The third activity of farmers is of special significance. It is the creation of county farm bureaus with the co-operation of agricultural colleges, and the United States and state departments of agriculture. These farm bureaus will not only make a study of the different systems of farming, live stock problems, the needs of the soil and farm management problems, but they will also keep general information bureaus and try to co-operate harmoniously with farmers, with producers' societies and with all the agricultural agencies in the county, to further marketing and the direct sale of farm products. This is most significant indeed as it promises that the farmer is going to solve his market problem by securing reliable data and by going about it in a thoroughgoing systematic manner.

\section{What Are Business Interests Doing?}

Transportation carriers especially have long since recognized the poignant value of having market bureaus that will assist the farmer in finding a market for his goods and in teaching him how best to prepare his goods for sale. The Pennsylvania and Long Island Railroads are among the railroads that have had virile market and experimental bureaus that have done yeoman service in marketing. The Lehigh Valley Transit Company has also done a work of inestimable service through its marketing system. Wells, Fargo \& Company has recently created an Order, Commission and Food Products Department, the aim of which will be to study the food products problem from various viewpoints, and to encourage and assist growers and producers by aiding them in finding suitable markets among dealers and consumers, and in securing, at minimum cost, suitable sanitary packages or containers in which to ship. "It is the intention of the department," says its organizer, "to gather 
information that will enable the producer, the distributor, the consumer and the carrier to keep more closely in touch with each other, to the very material benefit of all."

To be sure, those bureaus have been organized primarily for the purpose of furthering the business interests of the concerns affected. In furthering their business interests, however, they have also furthered without doubt the prosperity of the farmer, the business interests of the city, and remotely, no doubt, the interests of the consumer as well.

\section{What is the Consumer Doing?}

But what is the consumer doing, he who pays half his income for food? We certainly would expect him to be alert as to exactly the channels through which his food products are reaching him.

Quite to the contrary, he has done practically nothing. $\mathrm{He}$ is not even thinking, he is just wondering-wondering because he does not have the data with which to think.

Some consumers, to be sure, have voiced their demands through Housewives' Leagues, which have done much to give needed publicity as to certain ills in the food distribution world, to certain abuses by retailers, to certain types of misrepresentation, to needless costs to consumers through underweights and false measures. Other consumers have united in blindly groping for some kind of curative legislation that they hope will cure all the ills to which they have been subjected, though ofttimes, through this very legislation, their ills have been increased rather than diminished.

I have said that the consumer was doing practically nothing. But there is one thing he is doing. He is making up his mind that something must be done and that he is going to see that something is done. And that something will be done, no one can doubt. That it will be wisely done is utterly unthinkable, unless by sheerest luck, for the consumer does not have at hand the information essential for wise action:

\section{What is the City Doing?}

In the nineteenth century urban prosperity was linked closely with the growth in land values and the returns that came from exploiting the virgin soil. This source of wealth has passed away. The city must now rely upon the productive power of its average citizen. That productive power depends primarily upon how and at what cost that citizenary is fed. One would naturally think, therefore, that the city would certainly have been busied in formulating methods whereby food prices might be kept at a minimum.

But such is far from the case. Philadelphia is spending $\$ 100,000$ a year-and more is being spent in other cities-in studying the needs for a facile transit system that will get the wage-earner to his work; she is paying one market clerk $\$ 1,000$ a year in order to solve the problem as 
to what that worker can get with his money when he earns it. In other words, we are one hundred times more interested in getting the laborer to his work than we are in the purchasing power of his wage. The city must now choose between fortune building and citizen building.

\section{The Situation in the Cities.}

The New York Market Commission found that practically 60 per cent was added to the cost of food products from the time it landed in the New York City Terminal until the time it got to the New York consumer. In other words, the greater part of food distribution costs occur within the city's limits. We have talked much about the need of scientific management on the farm; it is time now to talk about scientific management in the city. The city is the place where there is the greatest waste and inefficiency in marketing food products.

What are some of the elements in this waste and inefficiency? To enumerate all of the elements in this waste and inefficiency would far exceed the possible limits of this paper. In the first place there has been no proper co-ordination between water terminals and land terminals. At least 5,000 vehicles in Philadelphia are used for haulage and cartage purposes. At five dollars a day for 300 days in the year, this totals an expenditure of $\$ 7,500,000$ annually. Would a better situation of terminals and a proper co-ordination of terminal facilities do away with many of these needless costs? Chicago is just now studying anew its terminal question. What of our water fronts? Herbert Knox Smith, Commissioner of Corporations, in a special three-volume report on "Water Transportation," has said: "Water-front warehouse space is inadequate, except at a few important ports. Modern trans-shipping machinery, except for bulk freight, is almost entirely lacking." Terminal facilities, though as important as channels, have been neglected; our harbors are not properly organized or controlled; railroads largely control water terminals often to the disadvantage of general water traffic; there is almost no linking up of the rail and general water systems at the water's edge, but rather the opposite tendency; there is little co-operation by localities with the Federal Government which improves their channels.

Do not these facts alone indicate that there is something very vital for the city to do?

Our cities are not planned for minimum distribution costs. If they were (1) the main depots would be so located as to be efficiently related to rail and water lines; (2) steam and rail lines would be co-ordinated in ample terminal facilities in harbors efficiently organized, with adequate trucking facilities at every terminal; (3) like attention would be given to good through roads, to local water routes and to trolley lines and terminals that local freight might be sent to just the section of the city where it is wanted; (4) there would be a public belt line railway co-ordinating transporting, manufacturing and distributing agencies; (5) the main centers 
of distribution would be connected by conveniently located streets, paved with special reference to their traffic. It is primarily in the city that inefficiency and waste exist, inefficiency and waste that affect food costs, standards of living, citizenship.

Then again the increase in transit facilities coupled with the growing demand for suburban homes and country residences has withdrawn from farming to speculative purposes countless acres near urban centers. Thus the farming country has been beaten back farther and farther from the city's gates, to the end that the farmer's marketing problem has become increasingly more complex. To bridge this chasm and to link city and farm as they were once linked require alert, constructive activity by the city, activity of just the kind a market bureau can render.

The problem of efficient marketing is essentially a city problem and the city has left it to take care of itself.

\section{What Can a City Market Bureau Do?}

There are primarily two points of view to be considered in getting at lower food costs through economic and efficient distribution. One of these is the point of view of the farmer; the other is the point of view of the consumer. A city market bureau can very definitely further the interests of both and thus administer to the needs of nine out of every ten of our population.

When the farmer in the country or the county agent himself comes to study the marketing problem, he finds that he is practically helpless on account of distance from the city. None of his own questions can he answer; none of his measures can be effectively adopted from without the city. European countries and cities have thought it wise to make it possible for the farmer to get public moneys in order to buy lands, and have lent financial assistance to farmers' co-operative societies and individual farmers as well. The American city, quite in contrast to these methods, can effectively help the farmer not only in marketing his output, but also in adapting, sorting, standardizing and packing that output to suit the city trade.

The question as to what a municipal market bureau can do can be answered in large part by reference to the author's own letter files. One farmer writes that he would like to market butter by parcel post, and wants assistance for finding consumers in Philadelphia. Another would like to find a good public market stall where he can sell his goods. Another would like to be recommended to a reliable wholesale jobber. Still another feels he can by the hamper method get in direct touch with many consumers if he can get a list of city dwellers who might care to consider the hamper method. Another writes that his freight rates are exorbitant and unfair. Still another holds that the freighting facilities offered at his station are wholly inadequate. Another finds need for the completion of a certain street within the city in order to have a thorough- 
fare from city to country. One farmers' co-operative association asks whether or not facilities could be made so that one of their boats could leave the New Jersey shore and find ample marketing facilities in Philadelphia. Many others have questions as to their output and marketing methods.

These are but examples of the kind of practical service a municipal market bureau can render. Here is a work which a city farm bureau, and a city farm bureau only, with thoroughgoing information, could properly and adequately handle. Without such co-operation, the county agents, producers' co-operative societies, farmers themselves will be relatively helpless after all when it comes to finding newer and better marketing channels.

Mr. R. B. Dunlap, County Agriculturist, with offices at Altoona, Pa., speaking of the value of such a bureau in rendering assistance to farmers says:

"Of course we are taking for granted that it would be 'competently manned;' to the County Agent it would mean that his time and efforts could be devoted more largely to the production end, because if a market bureau were to be of any value, it would have for one of its main purposes the standardizing of all products shipped from the farm for consumption in the cities.

"We are greatly in need of such a work. There are so many standards, so many varieties of ideas in regard to first, second and third classes of products that producers feel as though they have the right to ask firstclass prices. On the other hand, the retailers and consumers, in this city at least, are not demanding graded articles. First, second and cull apples may be found in the same lot. Eggs and butter are not graded, although good butter is receiving the premium.

"This state of affairs perhaps comes, in this section, from the way in which most of the country produce comes to market, mainly through hucksters. From these general statements I think we can see some of the big things a marketing bureau might do."

The consumer likewise has no means of knowing what the farmers are doing and what the farmers would like to do. No retail bulletins are issued in this country as in European countries stating to farmers what retail prices are. Farmers near Philadelphia have not the slightest notion as to what Philadelphia consumers are paying for their produce, nor do Philadelphia consumers have the slightest notion as to what farmers are receiving for their goods. This intelligence is essential to wise co-operation between farmer and consumer.

Such a market bureau could stimulate the formation of market bureaus in outlying counties, could render distinct assistance in regard to the sorting and packing of goods so as to fit them to the particular needs of the city's own market. In this way selling at home could be furthered. 
Where we are adding one to our rural population, we are adding three to our city population, and this city population is spreading rapidly in all our states. By furthering selling at home, therefore, national forces will be put to work that will bring sooner or later a shorter route from producer to consumer.

\section{Stable Business through Stable Costs.}

In the last fifteen years the retail prices of the fifteen main food articles for which the average workingman's family spends two-thirds of its income increased 57 per cent. During this time agricultural wages have increased not over one-third, railroad wages perhaps one-fourth, wages in the manufacturing industry from one-fifth to one-fourth. In other words, the purchasing wage of the laborer is rapidly decreasing. If the money wage continue to increase from one-fifth to one-third, while food costs increase from two-fifths to two-thirds, does it take a mathematician to tell that the American laborer will soon be on the poverty line?

This situation has ominous meaning to every business man in the city especially. Just so long as this situation exists there must be a discontent-a discontent justified by facts. The discontent, as all observers know, is already to the breaking point. While it exists business stability is simply unthinkable.

And yet the business man seems indifferent to a programme for lowering living costs. Were it not so tragic, if written to music this indifference would make good comic opera. Only through lower or at least stable living costs can there possibly be business stability or urban prosperity. In such a situation the worst radical is the one who urges that nothing be done lest it "disturb business." In such a situation only the one who does something is the conservative.

Is it not worth the business man's while to support staunchly a movement that will make possible urban welfare and country welfare? That will make possible the increasing of purchasing power in the country round about? That will unquestionably have its effect on living costs and the wage-earner within the city?

The establishment of a virile, competently manned city market bureau is a good first step in such a movement.

Mr. Felix Albright: We hear a lot about the high cost of living. Why, those men don't know anything about the high cost of living. These old white-haired men who took part in the Civil War know that wheat sold for $\$ 3.40$ a bushel; corn $\$ 1.60$; rye $\$ 1.50$; poultry about twenty dollars a hundred; sugar twenty-five cents a pound, and all the rest. Now, today, we have wheat at ninety cents. The great trouble is, they talk about educating the farmer. The farmer knows more than the city man does. The city people don't know how to pick out an apple. They can't pick out an apple to eat. 
Mrs. Sмiтн: They pick out a Ben Davis every time?

Mr. Albright: Yes. Now, the city people can learn something. If they are willing to come out to the country we will educate them. We hear a lot from these city men about farming. If they would come to us, they would know something. I know a man who bought a farm, over two hundred acres, and I was near enough to recommend a first class man to him to manage it. No, he didn't want that; he came over here and employed a scientific farmer, graduate of a college, to manage it. $\mathrm{He}$ managed it three years, and it cost that man fourteen thousand dollars over what he produced, and he quit in disgust. I live in the sand-hills of New Jersey-

\section{Mrs. Sмiтh: Have you got any boys?}

Mr. Albright: I have four of them, all farmers. I have had some experience with graduates from agricultural colleges. One of them spent half his time studying and he never amounted to anything. It was not in him. The Board of Health in Philadelphia and New York require milk to be delivered at a temperature of fifty, instead of sixty. Dr. Neff, in his every-day bulletin, says we have killed so many babies by shipping hot milk here, simply because the temperature was sixty, instead of fifty, but friends, the rest of your lives read the North American. If anyone reads the North American, he is all right. They said last spring about having milk come in refrigerator cars, which costs the farmer three cents extra for refrigerating, and Dr. Neff stated that there was such a high rate of mortality among children in June, 1913, I made up my mind that these babies must have been killed by having milk come in too cold. Now, that North American editorial comes next to the Bible with me. Now, we hear a lot about saving babies. I heard there were three hundred had died and yet they insist upon cold milk coming in. How are you going to save them? Cold milk won't save them. One of our members of Congress wants to have a law passed that we must not kill our cattle under two years. What are you going to do for veal? I think the people want education, and if they will stay with us farmers a while, we will educate them. Then talking about eggs; we have people come over to Jersey and buy up these sand lots and only stay a month or two. One party came and bought a big piece of land, and out of five hundred eggs they got eighteen chickens. We had seven hundred eggs, and were going to raise broilers, and I was going to supply hotels, and we only had one chicken which represented seven hundred eggs. I tell you it is worth a good deal to be a farmer, and there is nothing as green in the world as a city boy in the country. I think I have said enough.

Mrs. Sмiтн: I would like to hear from others.

Mr. Douglas: I am a city man born on a farm. I have brought eggs down to a wholesale commission dealer in eggs in Philadelphia, who 
candled them, and evidently the candler knew his business, for he said they were extra eggs, were laid yesterday. That was true and he showed his skill, but he would not take them. He said he didn't want them; they were too good. I went to another commission man and he said he would be glad to have my eggs, but he would only allow me five cents less than the market price quoted in the papers. The result is, I don't know what to do with my eggs, except to eat them myself. Then I went to another place, a fancy grocer, and I gave him a commission of five cents a dozen for all the eggs he sold, to be guaranteed on my part that they were delivered to him within thirty-six hours of the time they were laid, and he sold a few cases, but he said his customers really did not care for that kind of egg.

Mr. F. R. Stevens: I simply think that I ought to say, with all respect to our friend from the sand-hills of Jersey, that $\mathrm{I}$ have met in my years experience a great many farmers who take the same view of life that our friend does. I am willing to admit to him that a city man with only city training is as much out of place on a farm as a man is from the country who had never gone off his farm before and was suddenly called to a bank or clothing store or something like that. Both are absolutely out of place.

Now, we have progressed along lines of scientific training and original work. We know more of scientific training through schools of agriculture, and land is getting better tilled since. I have during the seven or eight years I have been in extension work made it a fundamental principle never, when I met a farmer, give him any kind of advice, unless he first came to me and asked me for my advice. Men typical of our friend from the sand-hills of Jersey have asked for the assistance of the agricultural department of our railroad and the agricultural department of the state and the Federal Government and other experimental and extension stations. Men have applied to me for assistance from among our present practical prosperous farmers, along our lines, and in the country. These men realize, as our friend has said, that there is a great deal that is practical, but they also realize that there is as much to be gained from a knowledge of the scientific end of it as anything else. I saw one man being told certain things to do by a man who is a graduate from an agricultural college. I said to him, "Why, that fellow is telling you things that would take you fifty years to learn." We have met with the experience of that gentleman and others of his type, in that it takes them fifty years to learn how to do a thing, but that is not the sort of a graduate agricultural colleges are sending out today. The colleges could not do without you, and yet they are going to assist you.

Mr. Eavenson: There is one thing I can't understand, and possibly some of you gentlemen can explain it to me, and that is: Why the railroads charge for refrigeration eight months of the year and only give four? The only reason I have heard advanced is that it averages the cost. 
The farmer should ask the consumer to pay for that, and it is no more than right that the consumer should pay for the refrigeration when they insist upon having cold milk.

Mr. Stevens: That may be due to local conditions. The line which I represent does not ship milk to Philadelphia. We do ship milk to New York. We start a train from Geneva which carries milk into the City of New York. The cars are arranged for refrigeration, and it is a special train, used for nothing else, and the charge from Geneva to New York, about 350 miles, and taking the empty cans back, and refrigeration all the way, is seven-tenths of one cent per quart.

Mr. Eavenson: That is charged for the whole year?

Mr. Stevens: The whole year.

Mr. Eavenson: We are charged eight months.

Mr. Stevens: At present we are icing the cars, and you must remember that you have ice eight months of the year, and that milk is brought out at three cents a quart in Geneva and delivered at New York at seventenths of a cent, which makes the cost in New York three and seventenths cents a quart, and it sells for nine. That is where to find the leak. The leak is somewhere between three and seven-tenths cents and nine cents.

Mrs. Sмiтh: If there are no further questions the meeting is adjourned. 


\section{Thursday Evening, December 4th, 8 o'Clock.}

\section{Counčll Chamber, City Hall.}

Honorary Chairman, Charles S. Calwell, Esquire, President, Corn Exchange National Bank, Philadelphia.

Mrs. SмiтH: We have a long programme before us and a very interesting one. Mr. Benjamin did not use his lantern this afternoon. He is going to run over briefly some of the slides that he has brought with him, which I am sure will prove very instructive. Then we are going to have the milk question and I hope we will have a very interesting meeting and that everybody will say anything that is in their minds. Being a farmer myself, I have a great weakness for the Egg Association at Cornell, because I cannot raise more than about fifty chickens. I would like somebody to come in my neighborhood and show me how to handle the situation, the output; get it to the markets, and all that sort of thing.

Mr. Benjamin: This afternoon I talked on the subject of "Marketing Eggs" and dwelt to quite an extent with the co-operative association which was started at the Cornell University among the farmers. This evening I have a few slides dealing with this co-operative organization on general marketing principles. If there are any questions I shall be glad to have you bring them up within the limited time that I have. The organization which we have at Ithaca, while it is purely local, we are organizing it with the idea of its being adaptable to other parts of the state. The organization is simply an organization among producers and is designed for the interchange of ideas, and deals with conditions where we have small farms, with very small flocks, in most cases 35 to 50 hens on a farm. We have some farmers who specialize with 75 to 1,000 or 2,000 hens, but what we have to do is to help the small farmers with 25 or 50 hens, help them in getting the eggs together and getting them to the consumers either through the wholesale dealers or direct to the consumer. We have various dealers: the country huckster, the country store and the small city jobber. Most of those are superfluous and should not be needed.

[Mr. Benjamin at this point used his lantern slides in a practical demonstration of the work of the association at Cornell.]

D. H. Steffans, Baltimore: I would like to ask a question. This afternoon you said that, as compared with six independent dealers in a certain field competing for the eggs of the farmers, there was a tendency to co-operate because of the lack of efficiency. Is that correct? 
Mr. Benjamin: Yes, sir.

Mr. Steffans: Mr. Opperman said that this lack of efficiency under the present methods cost us for eggs about $\$ 45,000,000$ a year. I so understood him. I can't understand why, in a co-operation of farmers to deliver their eggs to one point, there should be any lack of efficiency, providing they use part of their profits to pay the manager and secure efficient management in that way. How should there in that case be a lack of efficiency?

Mr. Benjamin: The manager's salary depends on the profit which is made.

Mr. Steffans: Or give him a share of the profits as salary.

Mr. Benjamin: Yes, that would be a very good way of overcoming that to some extent. What I meant to bring out was that when we hire a man to do a job, he is not going to be as vitally interested as though he had got to do that to get a living, but if his salary depends on the profits that he makes in the business, his efficiency is going to increase.

Mr. Steffans: But the situation at present is this: Your six independent dealers purchasing from the farmers inevitably form a combine to fix the prices. The farmers form a small combine and do business through one agency. You put six dealers into a field and they inevitably will combine to fix prices and grades.

Mr. Benjamin: I do not know of any such combination in our particular locality, although that perhaps exists. Perhaps there is no actual combination, but possibly there is an understanding. There may be something like that, although I do not know of any regular agreement. Of course, we have lack of efficiency due to duplication work, when we have several competing firms. There are six people doing the work which one organization might do, yet perhaps each one of them is working harder than one manager would, but one manager might be more efficient in the end.

Mrs. Sмiтн: We will now hear from Dr. Williams. Dr. Williams is a member of the Rochester Chamber of Commerce. He has made a very close study of the economics of milk. 


\title{
THE ECONOMICS OF THE MILK QUESTION.
}

\author{
By John R. Williams, M.D., \\ Secretary, Milk Commission, Rochester, N. Y.
}

For twenty-five years or more cities have been struggling to get pure milk and thus far few have succeeded. Why have they failed? The answer to this important question is the theme of this discussion. Since the very beginning of community life to the present day, the business of producing and marketing milk, with few exceptions, has been in the hands of a large number of men, each carrying on his share of the industry in his own way, duplicating in every detail all the labor and equipment of his fellow workers, with no thought of co-operation or co-ordination of effort, paying little heed to the laws of economy and efficiency and frequently subordinating the needs of the community to his own gain.

For years the community has been oblivious, utterly unmindful of the treatment it has been accorded. It has left the solution of its health problems, particularly the milk question, to a few sanitarians and the sanitarians have thus far failed to solve it. The ever-increasing cost of living and the frequently reported epidemics of disease and deaths due to bad milk are rousing the consumer from his lethargy so that today the doctor is being pushed to one side of the stage, the mother, the business man, the professional man, the mechanic, indeed the whole community are coming on the platform. They are demanding to know what is the matter. Hence this conference of diversified interests and the many similar conventions which are being held throughout this country. The failure of the individual to meet fairly and adequately the needs of the community, more than any other reason, is responsible for the rise of socialism and similar political philosophy. Hence if we, as individuals, wish to preserve our identities as such, if we wish to continue the milk industry as a private enterprise, we must get our ears to the ground, we must accept the challenge of the community, we must solve the milk problem.

What is the milk problem of the community? Briefly, it is securing an abundant supply of pure milk at a reasonably low cost. It is not enough to secure pure milk; it must be so low in cost to the consumer that it may be plentifully available in every home. The water problem of the city is not solved when the rich drink the bottled waters of the distant springs while the less fortunate are compelled to use the contaminated waters of the community. No more is the milk problem solved when certified milk is made available for the well-to-do, while the poor 
must use questionable market milk. Milk must not only be pure but it must be within reach of the man in average circumstances. The milk problem, therefore, has economic as well as sanitary importance. Indeed, since I have been studying the question, I have come to believe that it is mainly an economic question.

For years we have been wrestling with the problem in Rochester as you have in Philadelphia. We had always looked at the problem from the standpoint of bacteria and infant mortality and we made little headway. A year or so ago we began to view it as a business proposition; and because of our failures along sanitary lines, we made an economic survey of the entire dairy industry as it affected our city, and this is what we found. We discovered that upwards of 800 farmers were producing milk for our city, many of whom were shipping milk to you also, so that we have a mutual interest in this investigation. Most of these men are dissatisfied with the business. In a study of western and central New York we found that a large number of farmers had given up wholly or partly the milk business. Of 674 farms offered for sale, 439 were dairy farms. We found the farmers complaining of scarcity of labor, and as a result they were not cultivating their tillable land. We found them buying expensive cattle feeds instead of raising them. We found them breeding low-grade stock, using scrub bulls which never should have been permitted to live. We found them taking no pains to keep disease, particularly the dreadful tuberculosis, out of their herds. We found them each one drawing a few cans of milk down the same road to the little railroad stations for shipment to the city. We found many other wastes and duplication of effort.

Why were these farmers doing these things in such a poor and unsatisfactory way? The answer invariably was that the business from their point of view was not sufficiently profitable to make it worth while for them to do it in any other way and that they could not do otherwise than subordinate dairying to their other farm work. The results of our investigation gave support to these contentions.

At the present time the producer does not receive for his product a due proportion of the revenue paid by the ultimate consumer. At least this would appear to be the case when his risk, investment and labor are contrasted with that of the distributor in the city who takes for his services one-half of the proceeds derived from the sale of the milk. The average yearly price paid the producer for milk is four cents per quart; the average retail price received by the distributor is eight cents per quart. The average investment required for operating a dairy farm in western New York, producing 160 quarts of milk daily, is $\$ 9,000$. One dealer in the city can easily deliver the milk of three such farms. His total investment rarely exceeds $\$ 2,500$. Thus, three farmers in the country with an average investment of $\$ 27,000$ receive no more for their product than does one distributor in the city with not more than one- 
tenth the investment. Furthermore, the risks and labor of the farmer are correspondingly greater.

There are some points about dairying, however, which the producer cannot afford to overlook. The milk business is an all-year-round occupation for him. It keeps his labor constantly employed. It is a continuous source of income; and when properly conducted, it adds to the productivity of his farm. If milk producers, instead of acting as a large number of individual competitive units, each duplicating the labor and equipment of his neighbor, were to co-operate and co-ordinate their efforts, they could lessen both the cost of milk production and make it more profitable.

This can be done and, to a limited extent, is being done by the formation of cow-testing associations, co-operative associations for buying feed, bedding and by the breeding of high-grade stock. Another material saving could be made by establishing co-operative milk receiving stations at convenient railroad points where milk could be received, tested and paid for on the basis of quality and purity, where cans and pails could be sterilized, thus doing away with expensive equipment of the farm, and by the collection of milk on one or two trucks instead of each producer hauling his fraction of a load to the railroad. In short, the producer must study the economics of his business, he must check the waste and the losses before the community will listen sympathetically to his plea for more remuneration.

In the city we find the business of distributing milk in the hands of a large number of small dealers. There is a different dealer for every 200 families and a different milk wagon, horse and driver for every 125 families. If milk were economically distributed, one horse, wagon and driver should be able to supply at least 400 families. On most of our city streets we have a different milk company for every two to ten homes. In many cases several milk men will be found supplying one home. In one small home we discovered that nine peddlers were each leaving one pint daily.

This overlapping in routes means a tremendous waste in labor and equipment. By actual computation we determined that the total travel of these dealers is from ten to twenty times further than it would need be were a single dealer to supply a given section in an economical manner. The same wasteful method of delivery is employed in most of the cities of the United States, as was determined by the writer in a recent investigation of this subject. In the few very large cities of this country where great milk companies are to be found, this waste is not so evident, but in the smaller cities and towns it is quite common. (See Tables I and II.)

The waste in milk distribution is by no means confined to street equipment. Each of these small dealers operates a small milk room or depot in which will be found the apparatus necessary for the bottling and storing of milk. As a rule, these milk rooms are located in one section 
of the barn or in a wing attached to the family dwelling. The apparatus is usually of the crudest character, and yet in the aggregate it represents an investment far in excess of what would be needed to equip a sufficient number of model sanitary plants were the business of distribution centralized. It is scarcely necessary to refer to the unsanitary character and unfitness of the majority of these milk depots. For most of the small dealers the margin of profit is so slender and the risks and losses so great that it may be said to be a most precarious business. (See Table III.)

When a milk business is unprofitable there is a great temptation on the part of the dealer to repair his losses by adulterating his milk, abstracting cream from it, selling left-over milk as the fresh article, stealing bottles and so on. Milk dealers, as everyone knows, sometimes yield to these temptations, and they should not be too severely censured therefor because they are the victims of a badly organized industry.

The loss from the present uneconomical and wasteful method of milk distribution in the majority of American cities is very great. It is safe to say that in Rochester it amounts to at least half a million dollars yearly, which means that the consumer pays nearly two cents per quart more for his milk than he would need to were sensible methods employed. Were this great yearly loss to benefit even a few individuals in the community, it might, in a measure, be condoned. However, except in the instance of the very large companies, the business has not proven to be very remunerative.

It may be said that the present system of milk distribution has a three-fold evil effect on the municipal supply:

It leaves the business of marketing milk in the hands of a lot of untrained men who have no idea of sanitation, no adequate sanitary equipment, all of which is directly reflected in the quality of the milk.

It affords such a meager living to the majority of small dealers that it tends to make them dishonest and to employ unscrupulous methods in their business operations.

It imposes an unnecessary tax on the whole community.

If this extravagant method of delivery were to be supplanted by one in which a single efficient agency were to have control, it would bring about three desired ends.

It would make it possible for the consumer to get pure milk for at least one cent per quart lesis than he now pays for questionable milk.

It would enable the farmer to get a half cent more per quart for his product, and this additional half cent to the farmer would make it worth while for him to rid his herd of tuberculosis and to do many things which are now neglected because of the scanty profits in milk production.

It would make a profitable business for one distributing agency, besides giving it a dignity and standing in the community that would not be exceeded by any other public utility service. 
The consumer has a responsibility in the milk problem which should not be overlooked. Dairying is the only business which is not compensated on the basis of merit. Every other commodity in use is valued according to its quality. This is true of sugar, meat, fruit, vegetables and so on, but it is not true of milk. Practically all milk is sold on the same basis. The community does not distinguish in either price or patronage between the producer who makes clean milk, rich in butter fat, under sanitary conditions, and that of the farmer whose milk is of uncertain quality. Nevertheless the cost of milk production, like other commodities, varies according to the diligence of the operator and the care which he bestows on his work.

A milk which contains five per cent of butter fat is much more nourishing than is one which contains only three per cent and is therefore more valuable. At the present time the community makes no distinctions on this basis and pays as much for a milk poor in cream as it does one which contains a high percentage. Certain types of dairy cattle produce large volumes of milk of a low fat percentage. Other types produce smaller quantities of milk with higher fat percentage. Under the present method of buying and selling, the farmer is encouraged to propagate the first-mentioned type of cattle. The obvious conclusion from this is that milk should be bought and sold on the basis of its nutritive value and not according to its mere bulk. It may be said, therefore, that the community by its method of purchasing milk without reference to its food value, and without discriminating between the different grades of milk, puts a premium on bad methods of farm management and inferior products.

Those seriously interested in the milk industry and who have its welfare at heart can ill afford to much longer delay attacking these fundamental evils. As before mentioned, if the individual interests cannot or will not make pure milk possible at a reasonable cost for all the community, then the community itself will take it in hand. This would not be a revolutionary thing to do, for nearly every city in the United States at the present time is engaged in doing this very thing. Milk stations operated by the city for the benefit of the poor are now nearly as common as schools. The establishing of milk depots for the benefit of the whole community would not mean the adoption of a new form of government, but rather a question of arithmetic; not one of abstract political philosophy, but rather a matter of self-defense and simple numbers. I repeat, the question of pure milk is of vital public concern. Those engaged in the industry should solve it with the aid of the community. They can scarcely afford to do otherwise.

[From this point on, Dr. Williams illustrated his remarks by the use of the stereopticon.] 
Table I.-Showing the Excessive and Unnecessary Traffic by the Present Mrlk Distributors in Rochester, N. Y.

\begin{tabular}{|c|c|c|c|c|}
\hline Sections of City Studied. & $\begin{array}{l}\text { Number of } \\
\text { Homess } \\
\text { Supplied by } \\
\text { Distributors. }\end{array}$ & $\begin{array}{l}\text { Number of } \\
\text { Distributors } \\
\text { in Section. }\end{array}$ & $\begin{array}{l}\text { Miles One } \\
\text { Distributor } \\
\text { would Travel } \\
\text { in Supplying } \\
\text { Section. }\end{array}$ & $\begin{array}{c}\text { Miles Present } \\
\text { Distributor } \\
\text { Travels in } \\
\text { Supplying } \\
\text { Section. }\end{array}$ \\
\hline 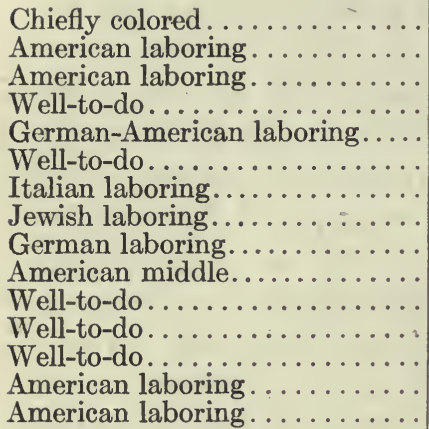 & $\begin{array}{r}165 \\
432 \\
340 \\
273 \\
508 \\
120 \\
353 \\
363 \\
145 \\
443 \\
166 \\
91 \\
216 \\
167 \\
786\end{array}$ & $\begin{array}{l}23 \\
55 \\
40 \\
27 \\
39 \\
14 \\
51 \\
57 \\
39 \\
26 \\
25 \\
17 \\
34 \\
31 \\
62\end{array}$ & $\begin{array}{l}2 \\
3 \\
3 \\
2.6 \\
4.4 \\
1.2 \\
3 \\
1.7 \\
1.7 \\
2.4 \\
2.5 \\
2 \\
2.5 \\
1.7 \\
5.4\end{array}$ & $\begin{array}{l}20 \\
45 \\
30 \\
24 \\
61 \\
12 \\
36 \\
30 \\
20 \\
48 \\
21 \\
14 \\
38 \\
21 \\
57\end{array}$ \\
\hline
\end{tabular}

Table II.-Showing Amount of Milk Used, Number of Dealers and Milk Wagons Employed in Distribution in Various American Cities.

\begin{tabular}{|c|c|c|c|c|c|c|}
\hline City. & Population. & $\begin{array}{l}\text { Milk Used } \\
\text { Daily, } \\
\text { Quarts. }\end{array}$ & $\begin{array}{c}\text { Total } \\
\text { Number } \\
\text { Dealers. }\end{array}$ & $\begin{array}{c}\text { Total } \\
\text { Number } \\
\text { Wagons. }\end{array}$ & $\begin{array}{c}\text { Average } \\
\text { Number } \\
\text { Quarts } \\
\text { per Wagon. }\end{array}$ & $\begin{array}{c}\text { Average } \\
\text { Number } \\
\text { Families } \\
\text { per Wagon. }\end{array}$ \\
\hline Chicago... & $2,000,000$ & $1,024,000$ & 1,300 & 3,000 & 270 & 135 \\
\hline Philadelphia. & $1,632,000$ & 500,000 & 450 & $1,500^{*}$ & 265 & 215 \\
\hline Boston....... & 735,000 & 271,000 & 257 & 641 & 230 & 230 \\
\hline Cleveland. & 600,000 & 100,000 & 441 & 641 & 125 & 185 \\
\hline Baltimore. . & 570,000 & 121,000 & 204 & 487 & 195 & 235 \\
\hline Buffalo...... & 445,000 & 140,000 & 260 & 450 & 250 & 200 \\
\hline Rochester. . & 225,000 & 90,000 & 220 & 360 & 200 & 125 \\
\hline Syracuse... & 150,000 & 42,000 & 78 & 194 & 170 & 155 \\
\hline Youngstown. & 100,000 & 48,000 & 170 & 185 & 210 & 108 \\
\hline Erie..$\ldots \ldots$ & 71,000 & 25,000 & 59 & 90 & 225 & 160 \\
\hline Harrisburg. & 67,000 & 20,400 & 195 & $195^{*}$ & 85 & 69 \\
\hline
\end{tabular}

NoтE.-The data for this table was supplied by the departments of health of the various cities. At least 20 per cent of the total milk supply of each city is used in wholesale trade or for manufacturing purposes. This allowance is made in computing domestic distribution.

* Estimated. Data not obtainable. 
Table III.-Showing the Total Accounting of Milk Distributors in Rochester, Grodped According to the Volume of Business Done.

\begin{tabular}{|c|c|c|c|c|c|}
\hline \multirow[b]{2}{*}{ Schedules. } & \multicolumn{4}{|c|}{ Distributors Selling Daily - } & \multirow[b]{2}{*}{ Total. } \\
\hline & $\begin{array}{l}\text { Not More } \\
\text { than 150 } \\
\text { Quarts. }\end{array}$ & $\begin{array}{l}\text { From } 151 \\
\text { to } 300 \\
\text { Quarts. }\end{array}$ & $\begin{array}{l}\text { From } 301 \\
\text { to } 1,000 \\
\text { Quarts. }\end{array}$ & $\begin{array}{l}1,000 \\
\text { Quarts } \\
\text { or More. }\end{array}$ & \\
\hline Distributors........... number & 25 & 101 & 44 & 3 & 173 \\
\hline $\begin{array}{l}\text { Milk, retail............ quarts } \\
\text { Milk, wholesale....... quarts }\end{array}$ & $\begin{array}{r}2,887 \\
129\end{array}$ & $\begin{array}{r}21,368 \\
2,411\end{array}$ & $\begin{array}{r}17,180 \\
3,415\end{array}$ & $\begin{array}{l}8,900 \\
6,000\end{array}$ & $\begin{array}{l}50,335 \\
11,947\end{array}$ \\
\hline Total milk sold....... quarts & 3,016 & 23,799 & 20,599 & 14,900 & 62,314 \\
\hline 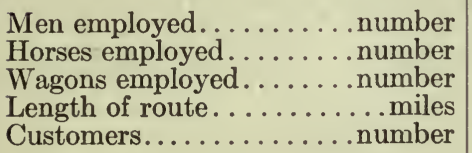 & $\begin{array}{r}29 \\
34 \\
26 \\
199 \\
1,885\end{array}$ & $\begin{array}{r}133 \\
160 \\
137 \\
1,053 \\
13,915\end{array}$ & $\begin{array}{r}99 \\
101 \\
92 \\
616 \\
9,490\end{array}$ & $\begin{array}{r}95 \\
65 \\
50 \\
641 \\
9,800\end{array}$ & $\begin{array}{r}356 \\
360 \\
305 \\
2,509 \\
35,090\end{array}$ \\
\hline 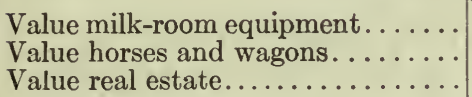 & $\begin{array}{r}\$ 2,407 \\
8,815\end{array}$ & $\begin{array}{r}\$ 17,295 \\
45,105\end{array}$ & $\begin{array}{r}\$ 16,750 \\
28,495 \\
\ldots\end{array}$ & $\begin{array}{r}\$ 38,450 \\
25,035 \\
96,700\end{array}$ & $\begin{array}{r}\$ 76,902 \\
107,450 \\
96,700\end{array}$ \\
\hline Total investment.... & $\$ 11,222$ & $\$ 62,400$ & $\$ 44,245$ & $\$ 160,185$ & $\$ 278,052$ \\
\hline 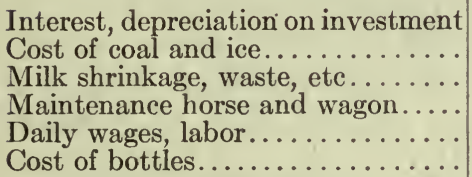 & $\begin{array}{r}\$ 6.17 \\
8.92 \\
4.35 \\
25.30 \\
5.60 \\
7.38\end{array}$ & $\begin{array}{r}\$ 34.17 \\
42.25 \\
36.59 \\
152.50 \\
48.95 \\
77.36\end{array}$ & $\begin{array}{r}\$ 25.16 \\
39.03 \\
28.55 \\
101.00 \\
74.20 \\
74.89\end{array}$ & $\begin{array}{r}\$ 45.15 \\
17.20 \\
14.55 \\
100.00 \\
193.06 \\
21.00\end{array}$ & $\begin{array}{r}\$ 110.65 \\
107.40 \\
84.04 \\
378.80 \\
321.81 \\
180.63\end{array}$ \\
\hline $\begin{array}{l}\text { Total cost distribution......... } \\
\text { Amount paid producer.......... }\end{array}$ & $\begin{array}{l}\$ 57.72 \\
128.71\end{array}$ & $\begin{array}{r}\$ 392.82 \\
999.55\end{array}$ & $\begin{array}{r}\$ 342.83 \\
880.44\end{array}$ & $\begin{array}{r}\$ 390.98 \\
886.40\end{array}$ & $\begin{array}{r}\$ 1,184.35 \\
2,895.10\end{array}$ \\
\hline Total cost to distributor. & $\$ 186.43$ & $\$ 1,392.37$ & $\$ 1,223.27$ & $\$ 1,277.38$ & $\$ 4,079.45$ \\
\hline $\begin{array}{l}\text { Milk receipts, retail............ } \\
\text { Milk receipts, wholesale } \ldots \ldots \ldots \\
\text { Cream receipts.............. }\end{array}$ & $\begin{array}{r}\$ 213.31 \\
1.00 \\
6.75\end{array}$ & $\begin{array}{r}\$ 1,535.05 \\
138.26 \\
60.84\end{array}$ & $\begin{array}{r}\$ 1,254.67 \\
195.87 \\
106.20\end{array}$ & $\begin{array}{r}\$ 682.00 \\
314.50 \\
67.51\end{array}$ & $\begin{array}{r}\$ 3,685.03 \\
548.63 \\
241.50\end{array}$ \\
\hline 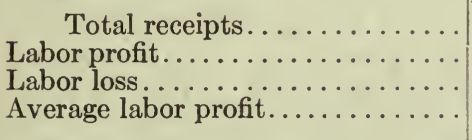 & $\begin{array}{r}\$ 220.06 \\
37.59 \\
3.96 \\
1.34\end{array}$ & $\begin{array}{r}\$ 1,734.15 \\
341.78 \\
\ldots\end{array}$ & $\begin{array}{r}\$ 1,556.74 \\
333.47\end{array}$ & $\begin{array}{r}\$ 1,366.01 \\
78.58\end{array}$ & $\begin{array}{r}\$ 4,876.96 \\
791.42\end{array}$ \\
\hline
\end{tabular}


Mrs. Sмiтh: We would like to have some discussion on this question by the milkmen present and the consumers. Dr. Williams would be glad to answer any questions asked of him.

Mr. Pile: Instead of 173 dealers, if there were only one dealer, what would they pay for the milk in Rochester?

Dr. Williams: One of the large distributing companies that have followed this question very closely and assisted me in following this investigation put at my disposal their equipment. They told me that if they could secure any part of the city which would enable them to operate satisfactorily, they would be willing to sell their very best milk for seven cents a quart. They would make a one cent reduction in the cost of distributing the milk and give the consumer something he is not getting now. That is the answer this company made to me and that is the proposal they made to me, providing I could find a market for their milk.

\section{Mr. Pile: Would they not take the cost off the producer?}

Dr. Williams: No, I am not in favor of that. I think the producer ought to get more for his milk.

Mr. Pile: Would that not be the rule?

Dr. Williams: If that phase were not safeguarded in some way. I find this, that in the competition between the producers and the distributors, I do not believe this problem will be solved until some harmony is developed. The Western New York Shippers' Association meets several times a year for the main purpose of conspiring how to get the better of the distributors; and the distributors meet once a month for the same purpose. It would not be necessary to overthrow any existing government to introduce harmony. Nearly every city in the United States is engaged today in the, milk business. We have almost as many milk stations in Rochester run by the city for the sale of milk for the poor as we have school houses. So it would not be a question of abstract philosophy.

Mr. Felix Albright: A number of years ago there was an organization of farmers to raise the price of milk. What did dealers do in Philadelphia? They went 400 miles into the State of New. York to get milk down here to destroy the organization. It cost them more money than it does now. They paid six cents a quart for New York milk and won't give us but $4 \frac{1}{2}$. They tried to kill us all. They have gone to work and got an ordinance passed that the milk must come down here in a refrigerator car. One of our committee bought a quart of milk of a dealer in Philadelphia and he had the doctor look at that milk and it looked very pure. No doubt he had extracted some of the cream, and it generated enough gas in fifteen minutes to blow the cork up to the ceiling. I was introduced to one of the best chemists in Philadelphia. Afterwards the government secured his services. I was introduced to him and he said, "I will show you what the people are buying for evaporated cream, which is nothing but four per 
cent milk, thickened with starch and chrome yellow." If you can get better milk than you did out of the small dealers, handling three or four small dairies, I do not know where it is going to come from. We have some good particular farmers who have good cattle and are taking good care of them, and then we have great big dairies that do not get much care. One of the best milk producers, a man in Burlington, where Mr. Supplee gets milk from, is going out of business because he cannot get help. He bought milk machinery, yet he can't get help. The greatest problem in the world is to secure help. Men are going out of the milk business because they can't get enough to produce the article that the Board of Health wants sent to the city. They require too much of the producer. They will send a man out on your farms who will talk about tuberculosis. A cow that is affected with tuberculosis does not give enough to pay for her feed, and away she goes. We don't want her. We are just as particular to keep away from tuberculosis as anybody. We don't want to see it. If you let the wind blow on a cow for six hours, she will not give the proper yield - they require so much. You might think we would have to spray the cows with rose water and cologne. They speak about better cattle. I have some of the finest Jersey cattle that stand on the ground. Burlington County had the reputation of sending the best iced car milk to Philadelphia some five years ago, and George Abbott secured the majority of that milk. He and Supplee are the best men in Philadelphia and pay the best price for the milk that they get. Some men get it and just keep inside the law. They talk a great deal about milk. We had a man who was paid about fifty dollars to come down and talk the money side of the milk pail. There is no money side for the producer and that is the reason he is going out of business.

Mrs. Smith: We have got about two minutes for one or two discussions.

Mr. Steffans: I have made a little study of the milk question. As was so very correctly put by the speaker, the production of pure milk at such a price as the city can afford to pay is the problem, and it will be solved only when the city producer and the country producer co-operate. To illustrate the point, we in Baltimore have an immense tobacco warehouse, in which the tobacco from the entire state is sent, graded and sold. We make our milk producers ship in milk, put it on an ordinary uncovered platform, and very often these cans stand out in the sun. The city inspector is running from can to can with his thermometer, and if it is above 60 degrees, he dumps it out in the gutter and the man has no redress. When we come to realize that we owe to the milk producer to take as much pains with the milk that he sends us as we take with that tobacco, then we shall have taken the first step at least towards helping him in getting pure milk. The ordinary municipal health department, with all its milk legislation, says to that man, "Thou shalt not do that; we will fine you. Do that, and 
we will dump out your milk." When did they ever try to co-operate? When did he ever erect a municipal receiving station at which the utensils could be properly sterilized before they are sent back to him? Where is the municipality that attempted to do that? Where is the municipality. that ever erected a municipal receiving station out in the country to try to organize the milk business and try to co-operate with the farmer so that the man could profitably sell milk at four cents a quart? Where is the municipality that will pay a premium for a low bacteria count and a high butter count? We owe it to the milk producer and farmer to try to cooperate with him, instead of simply saying, "Thou shalt not." Sending inspectors chasing around the farm, trying to tell him that he must do things which he often himself does not fully understand!

Mrs. Sмгтн: I would like to hear some of the milk dealers tell us whether they think it would be feasible to simplify the delivery of milk in cities having it delivered from one wagon. That proposition has been offered in some of the cities. Do the milk dealers think such a scheme would be feasible?

Mr. Harbison: We think it desirable but not feasible. Where you have 173 retailers, how are you going to eliminate 172? According to the figures quoted, the delivery of milk in Rochester amounts to about 63,000 quarts a day, and 90 teams could deliver the milk. That is approximately 700 quarts on a wagon. I presume in Rochester you have pint jars as well as quart. We know that 700 quarts of milk to a wagon, if you serve every day, is not practical, speaking from a practical standpoint. If you will ask every one of those 173 dealers whether they would like to have all the business, each fellow will tell you yes, I would request the other 172 to retire. Of course it is more economical if we serve at every doorstep, but how are you going to eliminate them? How is it feasible to eliminate the other fellow? If you people from Rochester can let me know how to make some money on the distribution of milk, we will be obliged to you.

Mrs. Sмітн: The figures Dr. Williams gave are very interesting. It requires a $\$ 9,000$ investment to have a plant which will produce 150 quarts a day. It is very interesting to know that. I would like very much to hear what the milk dealers have to say of the comparison between the farmers' investment and other investments. I have no doubt that some of the gentlemen here tonight have tremendous investments.

Mr. George Аввотt: I think I can best illustrate the point by calling attention to the ice dealers. They invest about $\$ 5,000$ or $\$ 4,000$ on an ice plant, gather the ice, and the ice dealer comes along with a $\$ 400$ team, horse and wagon, and takes that ice to the city and distributes it. We know perfectly well that in the house it is worth about $\$ 1$ a ton, and about $\$ 2$ a ton hauled in the city and retailed. He asks at least $\$ 8$ a ton, 20 cents a hundred. He retails it in small quantities at $\$ 12$ a ton. The difficulty of 
the situation is he is conducting a very bulky and a very wasteful business, and notwithstanding the fact that he is collecting from the consumer five times in that case what the ice costs in the house, and notwithstanding that is only one-fifth the investment, he still does not get rich. That is the point. With regard to the general proposition, I think we need consolidation, as the large dealers and the small dealers should get together and have a central plant. When we get to that happy condition, where the public will let us work out our own salvation, we will try to work it out, but the moment that we consolidate and come together, some newspaper charges us with conspiracy and we are threatened with prosecution under the antitrust act, and consequently we are debarred from a combination. It is not popular in these days to combine. We must go on in the old expensive way, and perhaps in the course of fifty or one hundred years it will all work out satisfactorily, but by that time some of us will be under the ground, I fear. There is no question but what it is a great work. It is well said that the farmer does not reckon his cost as he should. There is no doubt about that. He does not reckon his cost as the manufacturer does. The manufacturer who would produce upon the loose methods that the farmer does would go to the wall very soon.

In the matter of the distribution of milk there has been very great waste. There is no question about that. In running a dozen wagons in one block there is great waste. When all these factors are reduced to a good economical shape, the farmer will get more for his milk and the producer will not pay more for it, but will pay for what it is worth. They will learn to distinguish, as was drawn out here tonight, between milk of low bacteria count and high fat and a high bacteria count and low fat. The buyer does not discriminate and consequently we have a condition that it is very hard to get along with or to get results from.

Mrs. Smith: Professor C. W. Larsen, of Pennsylvania State College, is now going to speak to us on the "Cost of Milk Production." 


\section{THE FEED COST OF PRODUCING MILK.}

(In place of subject announced on programme as "Market Problems of the Milk Question.")

Carl W. Larsen, Dairy Department, Pennsylvania State College.

There are at the present time 933,640 dairy cows in Pennsylvania, as compared with 943,773 ten years ago. In spite of this decrease in the number of dairy cows, there has in the same period been a marked increase in the demand for milk. The population has increased from $6,302,115$ to $7,665,111$ in the corresponding years. Millions of gallons of milk are being made into products almost unknown ten years ago. The question naturally arises, "Why is this decrease?" Certainly the farmers of Pennsylvania are not selling their cows unless there is more profit in other lines of agriculture. Will this condition continue, or what will be the solution of the difficulty? There is no other product of the farm that is more important or more necessary. Milk will continue to be produced.

If dairying does not pay, why is it that almost without exception the dairy farmers of a country are prosperous farmers? The dairy localities, the dairy states and the nations in which dairying is carried on extensively are usually prosperous. Some will answer that the dairymen made their fortunes when feeds, labor, etc., were cheap. Others contend that by working 365 days in the year and by having the women and children assist with the milking and other work about the dairy, the combined labor income has accumulated until they have more wealth than their neighbors.

I am not prepared to offer a solution for this important problem. I suggest, however, that it will be met by both an increase in price and a more economical production. Milk, on the average, is not paid for in proportion to its actual food value when compared with many of our other food products, and when the consumer learns this he will be willing to pay a reasonable price for it. In actual food value a quart of milk is equivalent to three-quarters of a pound of sirloin steak.

One of the reasons why some dairies are unprofitable is because a wrong system is being maintained for a particular locality. For instance, an intensive system is many times practiced where the cost of feed and labor is high and the price of milk low. A dairy farm, on which the practice is to feed all of the grain to the cattle and at the same time purchase additional concentrates also to keep the cattle in the stable nearly 
all the year, besides hiring men to devote all their time to caring for the herd, cannot be profitable unless a good price is secured for the milk. Many dairies are over-capitalized. It should not be expected that cows worth $\$ 100$ should return a profit when kept in a barn worth from $\$ 400$ to $\$ 800$ per head.

The feed cost of producing milk is rapidly increasing. Bran that a few years ago was dumped into the Mississippi River by the carload is now almost too expensive to feed, while cottonseed meal, which, not many years ago, could be had for about the cost of transportation now sells for more than $\$ 30$ per ton and at that price furnishes protein cheaper than any other grain feed. Careful feeding and a study of the feeds available are necessary.

The dairy cow is a machine and a marvelous one. In nature she was intended to furnish enough milk to supply her calf, but by careful breeding, feeding and selection man has developed a machine that can produce enough milk to feed ten calves. A cow must be fed a balanced ration. She must be given a sufficient amount of the necessary elements to maintain her body and produce milk. A certain amount of protein and energy is necessary to maintain the animal and a definite additional amount for milk in proportion to the amount produced. A wheel maker with enough steel for ten wheels and enough wood for fifteen could make only ten wheels. In the same way a cow with enough protein for ten pounds of milk and enough carbohydrates and fat for twenty would only produce ten pounds of milk. She does not make milk deficient in protein, but is actually limited in production by the lack of sufficient protein. An excess of this constituent, however, would be used. Protein should be fed in sufficient quantities, but not much in excess, for it is more expensive than the other constituents. Recently a dairyman noticed an excessive feed cost, and when his ration was studied it was found that he was feeding enough protein for a cow producing four to five thousand pounds of milk more than his cows were producing.

A dairyman can no more feed a cow intelligently without a scale than a fireman can a boiler without a steam gauge. As a cow goes up in production she should be increased in feed allowance, and as she goes down she should be decreased. The more milk that a cow will produce the less will be its cost. The maintenance required is the same for cows of the same size.

The fewer cows necessary to produce a given amount of milk, the less will be its cost. Table I shows that the feed cost of 295 cows in Pennsylvania was 92 cents per hundred, or 2 cents per quart. These cows averaged 6,000 pounds per year. The cost of feed here was figured at $\$ 1.50$ per month for pasture, $\$ 10$ to $\$ 14$ per ton for hay, grain at about $\$ 30$ per ton and silage $\$ 5$. The hay item is a bit lower than market price for many parts of Pennsylvania, although much of the hay was only worth $\$ 10$ to $\$ 14$ in the mow. Had they been 9,000 pound producers, the 
cost would have been decreased to 78 cents per hundred, or .0167 per quart, and 12,000 pound producers to 71 cents per hundred, or .0154 per quart. In order to produce milk more economically, a larger number of high-producing cows must be maintained. Too many cows that only milk during a short period of the year and only produce a small amount of milk are kept in our herds. It is almost impossible to buy cows that will produce these larger amounts. It is, therefore, necessary that more dairymen raise their own animals. It is only by so doing that we will be able to secure good herds at a reasonable cost.

In Table II the feed cost of milk production was based on the sale or market price of the feed, except in the one case in which the New

\section{WHAT BECOMES OF THE FEED EATEN}

\section{When Fed Too Much}

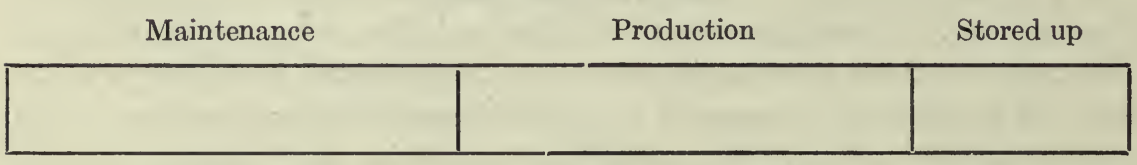

$1000 \mathrm{lb}$. Cow

$20 \mathrm{lb} .4$ per cent Milk

as gain in weight

JUSt ENOUGH

Maintenance

Production

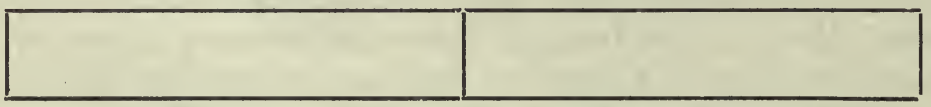

$1000 \mathrm{lb}$. Cow

20 lb. 4 per cent Milk

Too LitTle

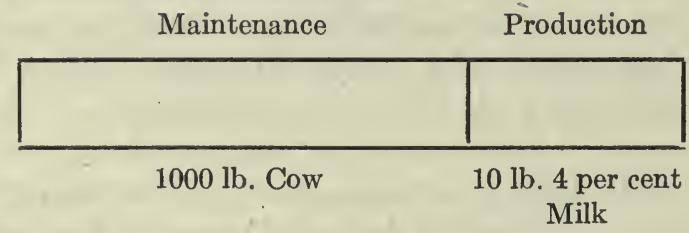

Jersey costs were based on both. The question of which figure to use has been discussed considerably, but it seems to me that unless the differential or difference between the cost of production and market price is considered, a fair comparison of farming methods cannot be made.

It should also be kept in mind that the feeds, although given as market value, in some cases they could not all be sold. For example, corn stover, although it has a good market in many localities in Pennsylvania, still in some sections it could not be sold to advantage. It is difficult, therefore, to determine just what should be charged for some feeds. 
What of the costs other than feed? I regret to say that my records of this study in Pennsylvania have not been completed. We are making a careful study of this subject from the standpoint of various practices and will within a few months have definite figures for these costs under Pennsylvania conditions. It will, however, be interesting to discuss the costs as found in some other states. Do they compare with our conditions? It will be seen by the following table that the cost of keeping a cow a year varies from $\$ 65$ to $\$ 74.70$, with an average of $\$ 70.77$. This figured in terms of cost, other than feed, is as shown in Table IV.

It is obvious from Table IV that it is even more important that our herds contain good producers in order to keep down the cost of producing milk. According to the above figures the feed cost per quart of milk is two cents for cows producing 6,000 pounds per year.

Let us now return to some of the main items of cost.

The labor item is a large one and one that is difficult to reckon under various conditions of farming. It must be kept in mind that the labor cost is greater on a farm where the man devotes all his time to the herd than where the herd is simply depended upon to furnish part of the income and other cash crops are sold. In the latter system the dairyman often makes a better division of labor. During a large part of the year a hired man may be used in milking cows without an additional expense, while at other seasons of the year the boys on the farm would be home from school and could contribute their share of work. I am not in favor of child labor, as it is generally considered, but I do believe that the physical and mental development for boys working on the farm under wholesome conditions is desirable. It is good training for the boys and at the same time helps to decrease the cost of labor, but when you consider farms where the practice is to employ a man for each ten to fifteen cows to devote all his time to them, there the cost per cow for the year reaches a large sum. At the present cost of labor, $\$ 30$ per year per cow。 is a reasonable figure. .

The items of housing and depreciation, although they vary considerably, are not small. As was suggested above, many herds are over-capitalized. The milking periods of cows are also often shorter than some suppose. If six years is considered as the milking life of a cow, $\$ 100$ animals would depreciate $\$ 10$ per year, figuring that she would be worth $\$ 40$ for beef. If less expensive cows are kept, of course the depreciation would be proportionately more. Some cows, however, will milk for ten or twelve years, while others fail to breed regularly and others have udder troubles and only have a short period of usefulness.

The cost of bedding as found in other states is about as we find in Pennsylvania. Where cows are kept in the stable the greater part of the year, I know of no system of bedding that costs less than $\$ 4$ to $\$ 5$ per year per cow.

Let us discuss briefly the returns other than milk. The largest of these is the manure. A cow will produce about twelve tons per year, and 
the results of the experiments at State College show that manure is worth on our soil about $\$ 1.50$ per ton as compared with commercial fertilizers. When the cost of hauling is considered and the losses taken into consideration, the manure per cow per year is worth approximately $\$ 12$. On some land deficient in humus the manure would be worth slightly more.

The other item of income is the calf, a variable factor. Calves from the average cow in the above herds would be worth from $\$ 3$ to $\$ 10$, or perhaps a little more, but not all cows breed each year; some calves do not live and accidents of one sort or another decrease the actual returns from calves. Bull calves from the grade cows are worth only a little.

My conclusion is not that you should sell your cows, but rather keep the good ones, feed a balanced ration, study feed costs and feed analysis, produce a clean, wholesome milk, and you will in most cases secure market prices for home-grown feeds and make a satisfactory interest on your capital invested and a fair compensation for your labor.

Table I.-Feed Cost on Eleven Pennsyluania Dairies.

\begin{tabular}{|c|c|c|c|c|c|c|}
\hline Number. & $\begin{array}{l}\text { Number } \\
\text { of Cows. }\end{array}$ & $\begin{array}{c}\text { Cost of } \\
\text { Roughage. }\end{array}$ & $\begin{array}{l}\text { Cost of } \\
\text { Grain. }\end{array}$ & $\begin{array}{l}\text { Total } \\
\text { Cost of } \\
\text { Feed. }\end{array}$ & $\begin{array}{l}\text { Pounds } \\
\text { Milk } \\
\text { Produced. }\end{array}$ & $\begin{array}{l}\text { Cost to } \\
\text { Produce } \\
100 \text { Pounds } \\
\text { Milk. }\end{array}$ \\
\hline 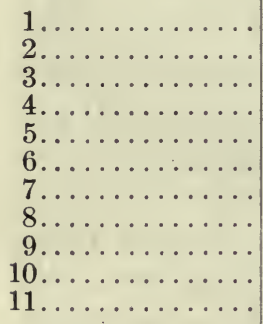 & $\begin{array}{l}18 \\
22 \\
53 \\
49 \\
13 \\
30 \\
16 \\
10 \\
19 \\
32 \\
33\end{array}$ & $\begin{array}{r}\$ 354.01 \\
708.25 \\
1,592.67 \\
1,501.83 \\
470.34 \\
1,194.45 \\
631.45 \\
332.35 \\
587.06 \\
1,057.31 \\
890.55\end{array}$ & $\begin{array}{r}\$ 749.11 \\
671.22 \\
677.90 \\
1,345.83 \\
297.32 \\
483.30 \\
388.47 \\
311.72 \\
617.70 \\
824.52 \\
909.47\end{array}$ & $\begin{array}{r}\$ 1,103.12 \\
1,379.77 \\
2,270.57 \\
2,847.27 \\
767.66 \\
1,677.75 \\
1,019.92 \\
644.07 \\
1,204.76 \\
1,881.83 \\
1,800.02\end{array}$ & $\begin{array}{r}110,391 \\
149,998 \\
288,397 \\
274,396 \\
79,695 \\
160,130 \\
125,203 \\
80,335 \\
117,451 \\
193,211 \\
199,294\end{array}$ & $\begin{array}{r}\$ 0.99 \\
.92 \\
.79 \\
1.04 \\
.96 \\
1.04 \\
.81 \\
.80 \\
1.03 \\
.97 \\
.90\end{array}$ \\
\hline $\begin{array}{r}\text { Total............ } \\
\text { Average....... } \\
\text { Feed cost per quart }\end{array}$ & $\begin{array}{l}295 \\
\ldots \\
\ldots\end{array}$ & $\begin{array}{c}\$ 9,320.27 \\
31.59 \\
\ldots \ldots\end{array}$ & $\begin{array}{c}\$ 7,276.47 \\
24.66 \\
\ldots \ldots\end{array}$ & $\begin{array}{c}\$ 16,596.74 \\
56.26 \\
\ldots \ldots\end{array}$ & $\begin{array}{c}1,778,501 \\
602,885 \\
\ldots \ldots\end{array}$ & $\begin{array}{l}\$ 0.93 \\
\ldots .02\end{array}$ \\
\hline
\end{tabular}

Table II.-Feed Cost of Milk-Other States.

\begin{tabular}{|c|c|c|c|c|c|}
\hline$\cdot$ & $\begin{array}{l}\text { Number } \\
\text { of Cows. }\end{array}$ & $\begin{array}{l}\text { Average } \\
\text { Pounds } \\
\text { Milk } \\
\text { Produced. }\end{array}$ & $\begin{array}{l}\text { Cost of } \\
\text { Feed. }\end{array}$ & $\begin{array}{l}\text { Cost per } \\
100 \text { Pounds } \\
\text { Milk. }\end{array}$ & $\begin{array}{l}\text { Cost per } \\
\text { Quart. }\end{array}$ \\
\hline 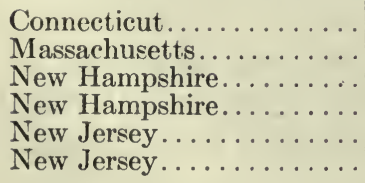 & $\begin{array}{r}124 \\
131 \\
203 \\
325 \\
31 \\
\ldots\end{array}$ & $\begin{array}{l}6,378 \\
6,036 \\
6,934 \\
6,463 \\
8,561 \\
\cdots\end{array}$ & $\begin{array}{r}\$ 84.07 \\
90.04 \\
74.35 \\
73.03 \\
* 121.60 \\
+95.73\end{array}$ & $\begin{array}{r}\$ 1.32 \\
1.49 \\
1.06 \\
1.13 \\
1.42 \\
1.12\end{array}$ & $\begin{array}{r}\$ 0.028 \\
.032 \\
.022 \\
.024 \\
.030 \\
.024\end{array}$ \\
\hline
\end{tabular}


Table III.-Cost Other than Feed in Other States.

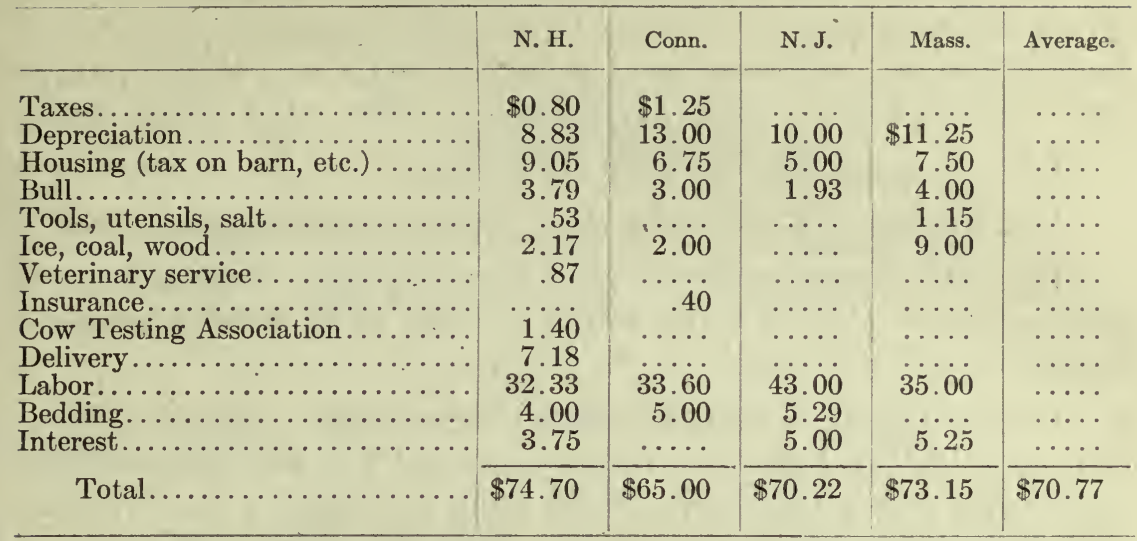

Table IV.-Cost Other than Feed

Computed From Table III.

\begin{tabular}{|c|c|}
\hline Pounds per Cow per Year. & Cost per Quart Milk. \\
\hline & \\
\hline 3,000 & $\$ 0.052$ \\
6,000 & .026 \\
9,000 & .017 \\
12,000 & .013 \\
\hline
\end{tabular}

Mr. Dulles: I would like to ask a question. You have the cost of delivery at 17.18. I figure the cost of delivery at about 21 . The freight is half a cent a quart within 25 or 30 miles of Philadelphia. That alone will figure more than 17.18 .

Prof. Larsen: As I tried to explain, these were not my figures, but they were collected from different cities.

Mr. Dulles: I was speaking because the figures are presented. Then I think there are two other items of the cost of delivery. One is the cost of hauling and another is the cost of shipping in cans, from the loss of cans.

Prof. Larsen: They are supposed to be included here.

Mr. Dulles: If that is included, I figure that the cost will be $\$ 22$ a cow instead of 17.18 , which is quite a difference.

Prof. Larsen: If you have got an 8,000 pound producer, you can pay that.

Mr. Dulles: No, you can't afford it.

Prof. Larsen: As I started out, a statement like that is absolutely out of place, saying you can't produce it for $4 \frac{1}{2}$ cents, without saying what the price of the feed is. 
- Mr. Dulles: Let me say that I have taken the feed at exactly the figures you have given us, because I have figured silage at $\$ 5$ a ton and hay at $\$ 18$ a ton, cottonseed meal would cost $\$ 34$ a ton, which is a little more than you figure it (at an average of about $\$ 30$ ), which is your figure.

Prof. Larsen: The dairymen are doing it.

Mr. Dulles: I do not think they do that on an 8,000 pound cow.

Hon. Mr. Critchfield: You said something about the great value of milk as a food. Which is the better, the milk which is rich in casein or rich in butter fats? Which has the best value?

Prof. Larsen: I cannot answer that question. Men who know more about it than I do, do not agree on it, and men who know as much as anybody, do not agree on it. Some claim that casein is more valuable and others claim that butter fat is. They are entirely different. It depends on what you are consuming with it. If you need fat to balance up with some other food you are eating with the milk, then it would be desirable to have fats; or if you are having fats in some other form, then casein would be desirable. I can't answer that question.

[The conference at this point adjourned until 10 o'clock Friday morning.] 


\title{
CORN DAY
}

\author{
Friday Morning, December 5, 1913, 10 o’Clock. \\ Council Chamber, City Hall.
}

Chairman, Clarence Sears Kates, Esquire, of the Philadelphia Society for Promoting Agriculture.

Mr. KATES, after calling the conference to order, made the following remarks:

With the enormous amount of extremely valuable information on agriculture collected by state institutions and our national Department of Agriculture, a constant effort has been made to render the data available to the man on the farm. Publicity in general was comparatively easybut to get the information to the particular individual requiring it was the problem. A number of methods were worked out; some were adaptations of older means, some quite new.

The bulletins of the state colleges, state experimental stations, State Department of Agriculture and our National Department, even city dwellers are familiar with; the farm journals and the general dailies were of course used, and will always be invaluable.

The next step was to send a properly informed man to lecture on his specialty at some chosen locality, the farmers of a neighborhood choosing the subject and the College or State Department of Agriculture providing the man.

A further advance was made when the agricultural educational train was evolved, an important point in its favor being that even if a farming neighborhood had not requested information-or halls were unavailablethe train itself was the lecture room, and advance notice was spread broadcast that on a certain day the train with a staff of lecturers would be on such and such a siding. This obviated waiting for initiative - and that was indeed an advance, as lack of leadership is a great drawback in rural progress as yet. But a serious disadvantage to all these sincere efforts was the lack of knowledge as to the conditions peculiar to the locality, limiting therefore the recommendations of thelecturers or experts to general directions; whereas if they could know the specific needs they could largely recommend a specific practice.

What was to be done?

The answer is found in what is termed the Farm Bureau and its County Agent. And too, it is at that point where the interests of the city 
can be connected up with the farms. Hence the Farm Bureau and County Agent as a topic for this morning's session.

But in addition to getting helpful information to the men who knew they required it, how about the still larger number who didn't know they needed it or lacked initiative to make some effort to get it?

And by way almost of interpolation at this point, the query made by some is, Why should such efforts be made to get information to people who have not gumption enough to try to get it for themselves? Let them go. Why should such backward fellows be helped or pursued? The answer to that, expressed in the lowest, most primitive terms is-it is not done for the benefit of those individuals but because the world must be fed-and that means you and me. And until we reach ideal farming, we must work with what we have that you and I will not starve during the period of reconstruction.

I hasten to say I do not subscribe to that answer as completely covering the reason, but it is an answer to "carping critics" or "knockers," whether the "knocker" is farmer or city-dweller, and some are found both in country and city. The opinion I have formed of the actual workers in this field of rural regeneration is of the highest-as a class or profession, their disinterested, unselfish work is quite equal indeed to the spirit animating our clergy missionaries, and I am extremely glad to have this opportunity to pay my humble compliments to them.

But to return to the programme. I have indicated that the Farm Bureau brings the city into direct relations with the country - the method for so doing will be explained to you by an expert later on. And I am very proud that the expert is a Pennsylvania man who has evolved ingenious, original and, of course best of all, absolutely practical plans.

By referring, to the developing of plans to reach the individual farm with such a bureau or organization, you should know that there are many other kinds of development required and many plans proposed. It has therefore become necessary in a territory so large as the United States to collect and study in a central place their many lines-hence its title, the Rural Organization Service. And the chief of that new work we are to have the pleasure of listening to and hearing at first hand somewhat of his plans.

Pure seed, true to type, is a matter of fundamental importance. The man who devotes himself to the improvement of seed through breeding is therefore serving mankind (which I would remind ourselves-means serving you and me) very directly and we will be privileged to hear (again at first hand) from one who is of the highest authority and a practical and scientific worker of the first rank, and who has paid us the honor of coming more than a thousand miles to fulfil his acceptance of our invitation. His address will add greatly to the value of our conference.

I believe that the Farm Bureau and its County Agent is destined to be the principal avenue for the rapid introduction of guaranteed true to 
type and pure seed, hence the appropriateness of that subject in connection with the Farm Bureau.

And lastly - an unexpected and unique use by a distinctly city institution of the highest standing has been observed in relation to the County Agent and I am happy to state that a great trust company sends to us an able and enthusiastic officer to describe their method.

You will please bear in mind that these topics are brought to your attention from the limited point of view of their advantage to the city, with the hope that the people of the city will be more alert to the necessity of their taking active steps in facilitating the introduction of more satisfactory methods of increasing their food supply, infinitely bettering the quality of the food and perhaps lessening its cost to the consumer.

And now it is but right, as it is indeed my pleasure, to express my sense of the honor that has been conferred upon me by my colleagues of the conference in inviting me to open this session. To President Calwell I extend my thanks for the honor and beg to have him accept my congratulations on the fine, broad-minded way he has developed this Corn Show and Agricultural Conference. And to the able and untiring president of the Pennsylvania Rural Progress Association, whose management of the programme and discussions is another example of her ability. I ask Mrs. Smith to continue her services at this significant session, significant because it is my hope that from it will eventuate a Philadelphia Agricultural and Marketing Bureau.

Mrs. Smith: I want to refer to an expression that I heard from Dean Russell, of Wisconsin. When the Wisconsin exhibition was out there last summer, somebody spoke to him about a certain meeting, an agricultural meeting, which took place, and said, "Was there anything accomplished by the meeting, or was it just a hot air fest?"

That is exactly what Mr. Kates wants to indicate, that this meeting is not to be a hot air fest.

Now, the Pennsylvania State Grange News, in its last number, quotes resolutions which were passed by the National Grange, and among others was this: "Resolved, That the excitement of holding agricultural meetings in various parts of the country, for no purpose whatever except an apparent desire on the part of people to uplift those who do not want uplifting" I am not quoting it exactly, but that is about the gist of it- "is to be discouraged."

Now, you see it is to be discouraged that people should get together with no object in view, but, as Mr. Kates pointed out, there is a very definite object in view and there is to be something left over from this conference. There is a real object before us and that is to assist in the solving of these problems, and there is very reasonable hope that the object will be attained. 
We have with us this morning a list of very distinguished speakers.

On the programme, first of all, you will notice Prof. T. N. Carver, who is chief of the Rural Organization Service, United States Department of Agriculture. He is an economist of great fame. His work on the economics of agriculture is well known, and what he has to tell us this morning with regard to the future plans for rural organization in this country will be of great interest to us and will give us the hope that something at last is.to be accomplished in a national way to promote the welfare of the farmers and, through them, the whole nation. I take great pleasure in introducing Dr. Carver. 


\title{
THE RURAL ORGANIZATION SERVICE.
}

\author{
Dr. T. N. CARver,
}

Director, Rural Organization Service, United States Department of Agriculture, Washington, D. C.

Ladies and Gentlemen; The problem of the economic distribution of the products of the farm is, as I presume has been stated several times already in this meeting, largely a matter of getting the city consumer and the country producer on a basis of mutual understanding and co-operation, but it is not a very profitable expenditure of time to discuss co-operation in the air until you have some definite scheme or plan according to which you are going to co-operate or upon which you are going to co-operate. All co-operation, which means merely working together, is, of courseand this is elementary-based upon mutual concessions and accommodations. People who will not concede anything or accommodate themselves to the requirements of other people, of course cannot work with other people and must work alone and, therefore, inefficiently. There is nothing to be accomplished by talking either to the farmers or the city consumers about the other fellow's faults. Leadership in this world has always been divided into two main types. One tells the people about their own rights, their wrongs, their grievances, but he never accomplishes anything except getting himself a little popularity at times. Nothing that is worth while is ever done by that method. There is another type of leader who tells the people nothing about their rights or wrongs or grievances, but tells them about their opportunities and their obligations. While this type of leader is not always the most popular, his is the leadership that is really constructive and that accomplishes results. The best illustration that we have at the present day is in the condition of the southern negro. There is a type of leader who sets up a fiery cross and tells the people about their grievances and their wrongs and tries to excite them into some kind of concerted action to get their rights and redress their wrongs. Then there is Booker T. Washington telling them nothing about their wrongs or their grievances, but telling them a great deal about their opportunities and obligations. We all believe that is the type of leader that is going to help the southern negro.

That is a mere preface to what I want to say about mutual accommodations and concessions which the city and country people must make. All moral principles, in fact, begin by getting the other man's point of view. The child cries and asks, "How would you like it if you were in 
my place?" That is elementary. All theories of justice and equity result from putting yourself in the other man's place.

Before a more economic method of getting the farm produce to the city consumer can be inaugurated the city consumers must be willing to spend a little more time and take a little more trouble in their marketing. So long as the city consumer expects to use the telephone a few hours before dinner and order the things which she forgot to get in the morning, she will never be able to trade directly with the farmer. So long as the farmer insists on dumping his produce in a nondescript and unstandardized condition upon the market, the city consumer will never be able to buy of him. The middleman will continue to be necessary, and there is no occasion for attacking him under those conditions. So long as he is a necessity, so long as the goods must go through his hands, he can charge whatever toll he chooses to charge. It is like goods on one side of the river and a demand on the other, but only one bridge and one man or one group of men controlling that bridge. So long as the goods must pass over that bridge and in no other way, the people that control that bridge can charge what they like. But if another bridge is built, and even though it is not so good, then that is a new channel that is opened up through which goods can go from one side to the other, and that will limit the toll which can be charged on the first.

The city consumer must, therefore, be willing to buy intelligently and take some trouble, and that means, first, to buy some time in advance and not expect to get instantaneous service. In the second place, the city consumer must be willing to buy standardized goods in standardized packages. So long as one consumer insists on having two eggs, another half a dozen, and another a dozen, and there is no uniformity, it is very difficult for the farmer to sell eggs to individual consumers in that way. But if they will get in the habit of buying standardized packages, then the farmer may be able to meet their needs, but not until then. That is not only true of eggs, but other produce as well.

On the other hand, as I indicated a few moments ago, so long as the farmer takes the easy way of selling his products in a nondescript condition, the city consumer cannot use the goods in that condition. $\mathrm{He}$ must have what he wants. He is not going to buy a nondescript lot in the hope that he may get something that he wants and throw the rest away, but the farmer must grade and standardize his own product; otherwise the city consumer will never buy directly in large quantities. If the farmer will grade and standardize his products, not only as to quality but as to package, so that it is marketed in uniform packages about the size that the average consumer can conveniently handle, that in itself will make possible the bridging of that gap between the two and therefore of reducing the toll which can be charged now by those necessary agencies through which the goods must be transmitted. 
As I said a few moments ago, so long as the middleman, particularly the commission man, is a necessity, nothing is to be gained by attacking him. He is a necessity. He is here to stay so long as conditions remain as they are. When conditions change so as to make him unnecessary, he will disappear automatically and you will not need to attack him at all. I have recently spent some little time in the best organized country in the world, I suppose, agriculturally speaking, Denmark. A distinguishing fact in Denmark is the way in which the farm products are standardized at the farm. We imagine sometimes that they have a great marketing association, but they have nothing of the kind, because when they standardize their own products at the farm they do not need to do much marketing. The buyers come and take the produce off their hands because the product is uniform in quality and absolutely standardized, and the buyer anywhere can order from any part of Denmark and get what he wants. For example, I will take one bacon-curing establishment at Frederickssund, in which I spent some little time. They were receiving orders daily from small grocerymen in New Castle and other English towns, besides selling large quantities to large buyers. The small groceryman in an English town can order from any of these co-operative bacon factories, because he knows that every hundred pounds of Danish bacon is like every other hundred pounds. The secret of it is not discovered until you get back to the farms themselves. You may ride a hundred miles through rural Denmark, visit a thousand farms, and look at ten thousand pigs, and you will find them all alike, of one breed and as nearly alike as animals of a standardized breed ever are. In the second place, they are all marketed at about the same weight. They figure that a pig from 180 to 200 pounds makes the kind of bacon which the English consumer wants. So the pigs are uniform not only in breed, color and quality, but in size. The curing process is standardized. One hundred pounds, as I said, of Danish bacon is like every other hundred pounds and the quality is guaranteed.

Mr. Egan, our Minister to Denmark, said that within a short time before we were there, the report came back from London that a couple of shipments of Danish butter had been below par. It was made a national issue. Apologies were sent around to the different legations, not that they had bought any, but because the people thought that somehow it was a stain on the national honor. Is there any mystery or magic about the fact that Danish butter sold well? The people have been told their own obligations and opportunities, but they have not been taught to lay the blame on the other fellow. They have risen to their opportunities under this teaching, and the world comes to them for its products. That is one case, at least, where godliness is profitable.

Let me summarize what I have said thus far. If the farmer will grade and standardize his own products, make them uniform in quality, put them in uniform packages, standardized in such form that the average 
consumer can buy it; if the consumer on the other hand, is willing to take a little trouble and not expect instantaneous service from the nearest store, but buys a little in advance and will buy in uniform, standardized packages, then the gap is bridged.

The next point is that not all the produce, or any large proportion of it, is likely to be sold directly to consumers. I should expect that a great amount of farm produce would continue to go through agencies of one kind or another. The first effort would be to substitute the jobber for the commission man. So long as the handling of farm produce is largely speculative, as it must be, if farm produce is nondescript, ungraded and unstandardized, the middleman does not like to assume the risk; he does not want to do the speculating and he throws it back on the other fellow. He merely receives it on consignment and the farmer must take the risk. When the farmer himself standardizes his product, so that there is a little less risk in handling it, then the jobber or the middleman ceases to become the middleman and becomes the jobber. That is the history of the development thus far. He buys it outright, takes it off the farmer's hands and distributes it himself. I should expect the man who makes that his specialty would probably continue to be distributing more economically in the mass than the farmer himself. But the fact that this other avenue is open, that the consumer can go to the producer without having to go through the intermediary of the middleman, or the producer can get his stuff past the middleman to the consumer, that in itself will limit the toll which a middleman, who will then become the jobber, can charge for his services. I should expect, as I said, the man in that business who makes it a specialty can do it far more cheaply than the co-operative society or any other society who tries to market directly, but he is compelled to do it cheaper by reason of the fact that it is possible for them to get along without him.

The same principle is involved here as in the theory of railway rates where a railroad has to compete with water transportation. Railroads in the neighborhood of the great lakes, for instance; it is well recognized that they keep their rates down by reason of the fact that water transportation is still a possibility. It is not necessary that the bulk of the freight shall go by water; it is not necessary that a very large percentage shall actually go by water. The mere fact that the channel is open limits the toll that the railroad can charge.

So, in this situation which I am describing, it will not be necessary that a large proportion of the farm produce shall be actually marketed through parcel post or any other direct method. The mere fact that that method is open and possible will force the surviving middlemen to do their business economically. If they can do that, it will force efficient methods upon them. I do not know that middlemen are different from other people. So long as conditions are easy we are certain to profit in a way, no matter what the methods are. The farmer, the middleman, the merchant and others are inclined to be a little slipshod in their 
methods. No economical society is interested in preserving a type of business after that business ceases to be necessary. When the consumer finds that he can get along just as well without certain products, the farmer that produces that kind of product becomes unnecessary and must go. The same will be true of the middleman whenever his services are unnecessary. There is no use in complaining about that. It is a law of the universe. Possibly some other kind of universe might be run on a different principle. That is not our concern.

I have mentioned grading, standardizing, getting a direct market and the effect which this will have on indirect marketing, which will be the principal method of getting the goods from the producer to the consumer.

Then there is the question of transportation. The chief difficulty is not with railway rates. I have recently been in Alabama and I have in mind the experience of a co-operative society in marketing strawberries. They have no complaint to make against railroad rates. They are willing to pay good rates for good service, but what spoils the business is the frequency with which a carload of strawberries fails to reach its destination. It is properly started on its way, it gets off on a side-track somewhere, is three or four days late getting to market, and the loss of one or two cars of strawberries is a pretty severe one to a group of co-operators. They would much better sell on the spot than to undertake to do their own marketing. They cannot afford to stand the risk. This particular co-operative strawberry growers' association has lost in the last two years several carloads of strawberries just by that method.

As I have said, they have no complaint against the railroad rates; they do complain against the inefficiency with which those goods are delivered. This is not meant as an attack upon the railroad.

I have not named any railroad. It happens that all these losses have come through the inefficiency of one particular railway system. It might be interesting if I should name that system, but I will not. I say this for the general benefit of the railway men who are genuinely interested in this problem of farm economics and the improved methods of distribution. One of the first things they ought to do is to see to it that perishable freight is delivered promptly. Perhaps they think they are doing it. The specific cases which I have mentioned, which I can vouch for, show that there is still room for improvement. I believe the railroads can do more for this problem by getting efficiency in service than by engaging in any kind of an educational campaign, although educational campaigns are always valuable.

Mrs. Sмiтh: What we need is this sort of a clear explanation of where we stand, what the condition of the country is, what we have to face and how these things can be remedied. We need to understand each other. We at these meetings represent so many different interests, the farmers, the commission men and the business men who are handling this food problem; also the people of the city, the consumers-all sides 
of this question are represented at this meeting. Consequently we need a clear explanation and a perfect understanding of where we stand. We had some misunderstanding and a little difference at the meeting yesterday, but I do not know but what it added to the general interest. That reminds me of a story that I am very fond of. I think the best storyteller is Booker T. Washington. He tells a story of when he was first starting to school, when he had great difficulty in getting a class room. Finally he had to resort to using a chicken house. He went one morning to a neighbor and he said, "Uncle Rastus, could you help me clean out that chicken house?" Uncle Rastus, a little confused, said, "Say, Brother Washington, don't you know any better than that? You can't clean out a chicken house in the daytime." [Laughter.] He misunderstood him, and that is the point here; we want to understand each other. We want to get together. That is what this meeting will certainly bring about.

We are now to hear from Mr. A. B. Ross, in charge of the Farm Bureau of Bedford County, $\mathrm{Pa}$. He has done a most unique work there and is often spoken of as the expert missionary, because of the fact that Mr. Ross is the first man, perhaps, to realize that this matter of training the farmer could only be done in the farmer's kitchen, with personal interviews, close touch with the men, and not through lectures, pamphlets and things of that kind. A farmer is like all the rest of us-he wants to be shown, and showing how he did it is what Mr. Ross is going to talk about this morning. We feel that this is a very significant talk that we are going to have from Mr. Ross. The thinkers of this country feel that Mr. Ross, more than any other man in the United States, has solved the question of how to bring the farmer to see this question of standardization, which Dr. Carver spoke of just now, and he has shown it to the farmer as a money-making proposition. I want to say this: we all go to Pennsylvania State College and state colleges and attend agricultural meetings. I am not going to knock Pennsylvania State College again, as I was accused of doing yesterday, for I feel anything but that way. I have the most sincere regard for State College, but I think that Dr. Watts would back me up in saying that the farmers could not see any better things than I did the other day, when we were taken through the food industry of this city, down on Front and Dock Streets, and see what these city people want to eat. I am a farmer, but I did not know they wanted chickens packed in white pine boxes, wrapped in paraffine paper. I did not know that the minute I washed an egg on my farm, that I spoiled the egg. How many farmers know that eggs do not have to be washed? How many farmers know that? They think they are extra careful because they wash the eggs, and they told me in the commission house that a washed egg is about half gone before it gets here. The worst thing to do to an egg is to wash it. Those are the kind of things that Mr. Ross is teaching in Bedford County, and I now take great pleasure in introducing Mr. A. B. Ross. 


\title{
THE FARM BUREAU; WHAT IT IS AND WHAT IT DOES.
}

\author{
A. B. Ross, \\ Assistant Agriculturist, U. S. Department Agriculture, \\ County Agent, Bedford County, $\mathrm{Pa}$.
}

Ladies and Gentlemen: I find I am down for three distinct talks. The programme says I am to speak about "The Farm Bureau; What It Is and What It Does." Mr. Calwell has asked me to tell something about the co-operative method of buying we have put into operation in my district. So, if you will send out for lunch for me, I hope to get through by evening.

The Farm Bureau is comparatively new. I think we can date its start only three years back; it has really started practically within two years.

We are just commencing to find ourselves and to realize what the thing means.

The bulletin was not successful; it did not reach the men we were trying to get at. It seemed that the possibilities of getting with the farmer, on his own farm, and working there, were worth going into. Anyhow, to make a long story short, we have found out that this method of approaching the farmer is the method, I believe, of the future.

The work must be done with the farmer on his own farm; there must be intimate touch between the agricultural expert and the farmer; there must be the consciousness that the work being done belongs to the man who is doing it, that the results of his toil are going to come to him, that the experiment belongs to him, is his absolutely, in order to stimulate better production, larger production and better methods on the farm. I believe in the long run we are going to carry to the farmer enormously valuable agricultural knowledge.

We have been working with the farm as the unit of our work. The county agent goes to the individual farmer and works with him on his farm and tries to reorganize his entire method of working and of accounting. He suggests better methods; he gets rid of antiquated implements, so as to make operations more profitable. And he sees that the plowing, harrowing and cultivation are done along modern lines.

But we have been working with units, single farmers. We are commencing, I am glad to say, all over this country, to realize the possibility of assembling these units into larger units, of co-ordinating them for co-operative work in our districts. And an even broader view is already commencing to show itself in various sections of the country, as shown by 
the communications that are being received at Washington. There is on foot an effort not merely to have the men within the several districts co-operate among themselves, but to assemble them into larger units of co-operation. For instance, in our own state, it has only been within two months that one of our county men originated the idea of our communicating with each other, so that each would be informed of what the other had to sell and what he needed in the way of agricultural supplies. So that our work will not in the future simply relate to the individual county man nor to the development of the individual county, but we will work together, will help each other out. This is brand new in agriculture; its significance is hard to measure.

I say that we are just beginning to find ourselves. It is suggestions of this sort that satisfy me that we are, in fact, just commencing to find ourselves. And this county agent plan, which Senator Gore said yesterday had extended rapidly and would be extended in the future as rapidly as possible until every county in the United States had its man, is going to mean a tremendous agricultural development.

But the county agent himself is only commencing to realize his opportunities; and in the natural development of his county he is going to find opportunities which it is impossible to measure in their ultimate outcome.

Take my own county, for instance. It normally divides itself into: (1) farm units; (2) then community units; (3) then larger marketing units. We have the community unit in Bedford County topographically divided into valleys and coves. Each valley and cove represents a certain type of soil, with possibilities varying from the very highest to the very lowest found in Pennsylvania.

In some of the sections, because of the topography, or on account of the conditions of soil, or both, the agricultural opportunity is about as poor as can be found in the state. On the other hand, some sections offer quite as good an opportunity as anything that can be found within the state.

The county man, working through his county and studying it, can find out these conditions; and he will also find an opportunity to develop each particular district along normal producing lines.

He will find that in a certain district somebody many years ago attempted to follow a line of farming that is not the best line for that particular district; and others followed his example. He will find communities in a tremendously hilly district, where the water problem is difficult and grass scarce, attempting to follow dairying, whereas they should be producing beef, pork and sheep. He will find other sections working in a regular rotation where dairying is the very best opportunity,

As he gets, from his travels and observations, a comprehensive view. he will be possessed of information which will enable him to work out a synthetic plan for the organization of the units within his county. And 
his influence in changing production, in diverting it to normal and profitable lines, is going to be enormous.

All of his field work is going, gradually but surely, to force that synthetic view upon him and enable him to do the work most needed by each community.

In my district, originally consisting of six counties, there are probably 400,000 acres of land today that is non-productive. All of this land is adapted to but one or two types of farming at a profit. One is meat production on lands which today are as bare of grass, almost, as this carpet, but which can be gotten into grass at small expense; the other is fruit, and fruit of the highest quality grown anywhere in the country.

It is possible to swing that land back into production, to compel it to bear its share of the burden of feeding this nation. It is possible to do it, and we are going to do it in the long run.

It is possible for the men in the more fertile districts, such as Chester County, who are not holding up their end of the game, to get their hills into grass. And where today there are practically no animals there could be raised animals to ship into Philadelphia and help supply Philadelphia with meat.

There is there as elsewhere a tremendous synthetic possibility that today is not understood but will be tomorrow; and it is going to have a direct bearing on the total food supply of the nation.

The Farm Bureau, as usually organized, is supported by three or four institutions, one the United States Department of Agriculture; another, State College, representing the agricultural side of the work; and the third, almost invariably, a chamber of commerce of some city that is located within the county. There is sometimes a fourth, the railroad or the railroads of the particular district.

The county agent, when he takes hold of the county work, is promptly swallowed up by the farmers. They absorb all his time. Yet he is partly paid by the chamber of commerce of the city.

What value is he giving to the city today for the money it is spending for his service? We have not found ourselves, but we are going to, on this proposition, too.

The average county agent is not seriously undertaking to supply his local city with wholesome perishable products and to so standardize food as to make it a certainty in the markets; which it is just as much his duty to do as it is to increase production on the farms.

He has not been doing this because he has been absorbed by the farmer. The farmers have been so anxious to avail themselves of his services that they have taken all his time; but he is going to realize, sooner or later, that part of his time must be devoted to the problems affecting the city; and for this reason. Go to any of the interior secondclass cities in Pennsylvania in the summer time, and you will find the average produce and fruit exposed for sale in the groceries is stuff which 
we in the country would hardly feed to a self-respecting hog. Altoona, Johnstown, Wilkes-Barre and other cities in our state today are supplied with food that has long since passed the state in which it is thoroughly wholesome. We must get the county man to help supply, in place of that, stuff which reaches the market in first-class condition.

I have spoken at some length about the Farm Bureau and what it is doing. What it is going to do is another matter. It must reach out and cover this food supply proposition, not simply for its own district, but help to supply food for Philadelphia and other large cities.

The question which confronts us today in Philadelphia is not simply the high cost of living, as that problem will solve itself when we have followed out the suggestions of Dr. Carver to standardize our stuff and ship it by more direct methods and procure from the present distributing agencies the service they can give us if they will. We have another and quite as serious a problem, that of supplying the laboring man, who is the backbone of all our city institutions - of supplying him and his family not simply with cheap food, but with wholesome food; and we must give him what we might call a wider selective ration. His food must not be confined to a few articles, eaten day after day, but, so far as it is within his means, he must have a choice of a number of things from which to select his daily food. And this is not only because it is a question of health but also a question of efficiency in his work.

He must have wholesome, palatable food, properly varied, to be contented; because a man, unless he is in a contented state of mind, unless his interior machinery is working smoothly, humming like a motor at its best, cannot do his best work.

So the food supply reaches to the very foundation of things, involves the manufacturing efficiency of the unit and, for that reason, affects the commercial supremacy of the city.

It is a question of such importance, viewed in this light, that every manufacturing interest in the city should take a strong interest in any effort to better the food supply of the city. They simply cannot afford to do otherwise.

At the request of $\mathrm{Mr}$. Calwell I want to describe to you briefly a method we are using in buying supplies for the farm.

Our present system of agricultural education is strong in the middle and weak at both ends. We are training the farmer along lines of better and more economical production, striving to increase his crops; but no provision is made for training our men so that they will go into the field and teach the farmer how to buy effectively in order that he may produce more economically; and, at the other end, we are not training our men so that they can show the farmer how, when he has produced stuff for the market, to market it so that it will take its proper standing in the market and the farmer will get out of it what he is entitled to. We are not teaching him how to standardize and grade and pack and handle his stuff so that it will bring what it should. 
We must find some means to educate the men in the field for this work, because the farmers are commencing to demand that this phase of their work be looked after. That demand is going to grow, and we are going to have to meet it eventually.

I don't believe very much in making new commercial machinery. I do not believe in experimenting where there is already machinery adapted for the work in hand. I do believe that there is now in existence plenty of machinery to handle all our problems both in buying and selling.

The machinery that we use in our buying operations is perfectly well known to every merchant in Philadelphia, but as equally unknown to almost every farmer in the state.

In our buying operations we use what is known as the negotiable bill of lading.

When goods are shipped by the wholesaler they are always shipped in one of two ways. He either ships direct to the consignee, expecting to follow with a bill, so that the consignee can go to the freight station and get his freight the moment it arrives; or he ships to his own order, at destination, and draws on the consignee for the value of the goods, attaching to that draft the bill of lading. And in this latter case he uses the negotiable or order form bill of lading. To this bill of lading and draft he attaches an invoice or bill of the goods showing what has been shipped.

The order form bill of lading represents the ownership of the property, and it must be endorsed the same as a promissory note and turned over to the buyer before the latter can get that freight.

So the shipper sends the draft to the buyer's bank, with the bill of lading, representing ownership of the property, the buyer pays for the goods, secures the bill of lading and takes it and goes to the railroad and lifts his freight.

It is extremely simple machinery. It protects the shipper because he receives from the buyer's bank the money to pay for the goods before the bill of lading, representing ownership of the property, is surrendered to the buyer. It protects the purchaser because the purchaser need not pay the draft, under our present system, until the freight arrives. Then, if he desires, he can inspect the property. And we buy on guaranty.

It further protects the purchaser in the matter of his money to be paid for the purchase because that money never leaves his own home bank. Our local farmers' exchange 'will not handle any money; the member must deposit it in his own bank and that bank notifies the exchange, when sending the order, that the money has been deposited. So our plan offers the valuable service of bringing together the wholesaler and the consumer. The operation carries with it almost no overhead expense, because we keep no books; we simply bring the wholesaler and consumer together.

Last year we purchased under this plan, from March 1st until fall, 
about $\$ 6,000$, and this year about $\$ 12,000$ worth of goods; and the work has gone through in splendid shape.

We have not confined our work to Bedford County nor to the original six counties of my district. We have shipped, for instance, to Chester County. As a matter of fact, we have shipped stuff under our plan, or arranged for shipment of it, as far west as Kansas and as far south as Alabama.

The plan is simple, direct, absolutely clean and economical to the last degree. We keep no books, because none are necessary.

We have also a system of keeping track of all shipments made by wholesalers, a postal card advice from wholesalers giving the details of shipments, the car number, bill of lading number, date and all other information necessary to start a tracer in case the shipment is delayed in transit. This postal card is mailed to us by the shipper at the time shipment is made. That same information is repeated by us on a postal card to our member, with instructions that if the freight has not arrived at a definite time stated on our postal, he is to notify us. Where such notice is received we start a tracer at our end and advise the shipper to start one at his end of the line.

Two or three times we have had delayed shipments brought to book by tracers, and once we had a lost shipment that was never found.

In case of lost shipments the exchange handles the claim, and also in case of damaged shipments. We have always had prompt adjustment of these claims.

That, briefly, is our draft-attached-to-bill-of-lading plan, which we think is the best and most economical method of co-operative purchasing devised up to the present time.

No such seed has ever been received in our district as that bought under our plan. I want to say that the cleanness of our plan has brought out of the wholesaler absolutely the best that is in him. Last year houses with which we had dealt for the last five or six years refused to quote the exchange prices on alfalfa seed, because they said it was not up to what they knew the exchange required. We have had that occur with three houses, a refusal to quote us prices on material which fell below the high standards we require.

We never quote prices to our members on seed except it is the best the market offers, because the best seed is the cheapest. The question of price we regard as secondary. That is our purchasing plan.

We are now at work on a development plan, using the Bedford Division of the Pennsylvania Railroad as a unit for the plan. We propose to develop each part of the territory tributary to this division along normal and profitable lines of production. Our proposition is to standardize all products from the very ground. We propose even to select the seed with a view to uniformity of product; and we propose to standardize everything shipped. That plan is not in shape yet to talk very definitely about it. 
Yesterday I was in conference with Mr. Kates, chairman of this meeting, and with several other gentlemen; and I was authorized to say that the outlet so essential to our plans for production and standardizing products will be furnished in part through the earnest efforts of the best people in the City Hall, city officials, who have an earnest desire to forward a movement which means wholesome food, brought here and delivered by more direct methods.

This outlet, together with that to be furnished through the new bureau now under consideration, we believe will ultimately mean a serious reduction in the high cost of living, The furnishing of an adequate and safe outlet should stimulate production and curtail waste and thereby effect this reduction.

MrS. SMITH: I have such an advertising kind of a mind that when a gentleman presents a fact that I feel ought to be shouted, I want to get up and shout. Last summer we were exactly in the position of these farmers that Mr. Ross told us about. He has not told you just exactly how serious a need the farmer has with regard to these seeds and fertilizers at better rates, owing to the fact that they cannot get them. Many do not want such stuff that the houses that furnish them will consider wholesale rates for. That time we were dealing with the problem for ourselves, having gone to a farm of our own which had always been a tenant farm, where the weeds had been grown along with the crops. We had not a bushel of oats, and we had not even any hay then and had to go to the mills, and there we found just what exists all over the countrythat the big mills have the farmer by the throat and that is a fact. If there are any farmers here they will tell you so, and to many of you business men it is a matter too deep for me to explain. Really, the man you like very much, your local miller, perhaps, has nothing to do with it. $\mathrm{He}$ is under the dictates of some larger scheme, but in some cases he is a very fair-minded man and discusses it with you, and sometimes puts up a trick as he did with me last summer, when I went to him and asked how much corn was a bushel. He said, "80 cents." I said, "How much do you want for cracked corn," and he said, "90 cents." Wasn't that kind to me, selling me cracked corn and only charging me ten cents for it? I said, "Just what do you do with the corn meal?" He said, "Nothing." A kind of a red glow went up over his face and he looked at me with a serious eye, I guess saying, "She is a deep one; she certainly gets me into things I didn't know I was going up against." He thought that I thought that the whole corn was there. Some of us do think that. They sell whole corn at 80 cents and sell cracked corn at 90 cents. What do they sell corn meal for? $-\$ 1.60$ a hundred.

We have with us Mr. Lardner Howell, of the Girard Trust Company, who is going to speak to us for a few moments on the "Trustee-Landlord and the Farm Bureau." It is interesting to those who own farms to know 
what the trust companies who have charge of their estates can do with farms. I am glad to testify personally to the fact that the Girard Trust Company has taken a novel and constructive attitude towards the whole farm question. It is very pleasant to know they are using experts, and I take pleasure in introducing Mr. Howell. 


\title{
TRUSTEE-LANDLORD AND THE FARM BUREAU.
}

\author{
Lardner Howell, Esquire, \\ Assistant Trust Officer, Girard Trust Company, Philadelphia.
}

Girard Trust Company appreciates the courtesy of the invitation to join in the movement to bring to a better understanding the relationship between the country and the city, and not only the privilege of taking part in this programme, but the opportunity afforded to its tenant farmers by the Corn Exchange National Bank to participate in the corn contest. Six entries have been made by its tenant farmers.

The company, in its fiduciary capacity, is steward of several farms, of which fourteen are located in the immediate vicinity of Philadelphia. In fulfilling its duties as steward, it has had Mr. John M. Okie, of its Real Estate Department, co-operate with its tenant farmers for the past six or seven years. Bulletins issued by the government and state colleges have been distributed, and, by the able assistance of Professor Hayward of the Delaware State Experiment Station, practical demonstrations on several of its farms have been made, which have been of material assistance, not only to the farms visited, but as well to the adjoining properties; and, in addition, by these demonstrations a community interest has been awakened. Last spring Mr. Okie escorted a delegation of six or seven of the tenant farmers to the Delaware Experiment Station on Farmers' Day.

With the advent of the county agent, it is felt that many vexing problems may be met, and the farms further developed by the close cooperation of the landlord, tenant farmer and county agent.

The tenant farmer has many responsibilities, and has not at his command, as has a president of a bank or trust company, the assistance of its officers and corps of efficient bookkeepers to work out the problems arising from day to day. He alone meets the situation. In his position he is independent and, by the fact of his independence, is very dependent.

Efficiency is one of the largest assets a farmer can accumulate, and with the assistance of the farm agent this efficiency may be obtained. For example, much time and labor are lost in tilling small fenced-in fields, and it may be shown that part of this work is unnecessary and could be avoided under proper direction, and also that, by making conditions sanitary, the dairyman may be able to obtain a higher price for his products. The landlord, in co-operating with his tenant with this end in view, is thereby not only more certain of the collection of the rent, but is, by this co-operation, aiding in the producing of the rent and assisting in making his tenant of value to the community. 
Mrs. Smith: The point of view presented just now was exceedingly interesting, especially as it is suited to the city man who needs broader points of view on the farm question. As you know yourselves, nobody but a man who is used to farming and handling farms all the time can very often work out these problems regarding the farm.

We have got some farmers here today, and I would like to ask them what they think of the Six County Farmers' Exchange that Mr. Ross spoke about. We have a few moments for discussion, and I would like to hear some of the farmers say a word on the need of "buying-associations" in farm districts. We have got some men here who are actual farmers, who know all about the ins and outs of farming. I would like to hear from those gentlemen. What do they think-that the farmers need to get together on the buying proposition?

Dr. J. Russell Smith: I cannot pose as an expert farmer, but I happened to get to a place where the Six County Farmers' Association was doing business. I wanted to get some beans and I wanted about eight bushels. I did not know what kind I needed and I did not know where to buy them. I asked them to tell me what kind and where to buy them. I signed a slip, paid a quarter, got good beans and I saved about two dollars on the transaction besides the saving of time. It was a very profitable transaction to me.

Mrs. Garrett: I am not a farmer. My husband, who is a farmer, has gone out and I wish he were here to tell you this. I wish somebody had bought our alfalfa seed last summer. I think if we had advertised through the farm bureau, it would have been a very good thing for the Garrett family.

Mrs. Sмiтн: I understood that the farmers all over the state can join and that arrangement can be made whereby carloads of fertilizers and seeds can come to our local districts.

Mr. Ross: It is all a wholesale business, no matter what we order. There are two advantages: in the first place, by getting enough to buy in carload lots you get the carload rate; in the second place, when you buy them they are all shipped together. Where a number of neighbors get together, one man can go and bring it all back instead of all of them.

Mrs. GARrett: Can we get lime from your organization?

Mr. Ross: In Chester County they have their own lime.

Mrs. Sмгтн: The lime as a community proposition is one of the things we hope to take up at the meeting, because it is a question of development and transportation. Mr. Prouty, of the Interstate Commerce Commission, was to speak on that question, but the sudden death of a member of the Commission placed added duties of the Commerce Commission on him, and he could not get away from Washington. I am very sorry. 
I have been closely in communication with some of the lime dealers, because I am interested in knowing the length of time it takes to make it right. I was born right next to a lime quarry, so I do not know what other people do who do not have lime quarries next door to them. I find in several sections of the country they send hundreds of miles for lime. It seems to me that it is a terrible condition to be without lime. It takes a railroad about a year and a half to make a rate on lime for a certain section. It seems to take all the red tape that there is in the railroad business - that is, with some railroads. Some are more efficient. I have been waiting to find out how long it would take a railroad to make a rate between our section of the country and Poughkeepsie, N. Y. I think they have been at it about eight months now. That is one of the questions that we want to take up here, but I hope there will be time later. Time is moving on and we have got to cut this short. We want to hear Mr. Don Blair speak to us on the question on increasing grain production.

Mr. Kates will offer a suggestion at this point.

Mr. Kates: I want to read again the two closing paragraphs in the editorial that I read to you this morning. In view of what you have heard, I would hope that some action might be expressed in the nature of a resolution, which I have here. I believe that if this resolution was endorsed by those that are present here, that we could establish a foothold for the work in Philadelphia such as has been indicated by Mr. Ross in his able presentation of the work he has in hand, which, as you will remember, has the endorsement of the United States Department of Agriculture. What I said early this morning I thought was a challenge.

Editorial referred to and read by Mr. Kates earlier in the session is as follows:

\section{The Conn Show: Will It Help Producer and Consumer?}

(Public Ledger, December 5, 1913)

"President Calwell and the Corn Exchange National Bank are to be congratulated upon the initiation of what is called their Corn Show. This conference and exhibit is much broader in its activities than the attempt to stimulate farmers to grow two ears of corn where one grew before; it is the beginning of a movement to make the food supply plentiful and cheap; to help the farmer by aiding him to help the consumer; to bring the two classes together with directness and to eliminate, if not all middlemen, at least some of the intervening profit-takers.

The originators of the Corn Show have enlisted the hearty co-operation of the great educational institutions of the state, practically every trade body and commercial instrumentality of the city, the Pennsylvania Railroad Company and improvement and other public spirited organizations. They propose to form a plan of action which shall provide better marketing 
facilities, for quick transportation, for the uplift of the producer of food stuffs, for market bureaus to help along the produce from the farm to the household and, finally, as specific instrumentalities to those ends, to institute a farm bureau in this city which shall act as a clearing house for the farmers of this and the two contiguous states.

The consumer is to have the means of dealing with the farmer. The Corn Show and its eventual bureau are not to be agencies to teach farmers how to grow crops; other agencies are engaged in that work, but they propose to help the farmer by bringing him into instant and profitable contact with the consumers and from that profitable conjunction the farming interest will receive its stimulus and ample reward.

Let us hope the projectors will actually accomplish something. The meetings are instructive and interesting; but there have been so many meetings and so many pamphlets, speeches and prospectuses that an anxious and suspicious world has arrived at the point of demanding some concrete result.

The Corn Show and the activities of its public-spirited, enthusiastic supporters will prove a failure if the project shall not be pursued to the logical end of attaining some practical result, but if only a beginning shall be made in bringing a few farmers with their butter and other produce to the doors of a few consumers they will perform more than scores of similar movements which ended in mere talk.

Let Philadelphia try one experiment; let it open the way from the farm to the city household; let it make one successful step in quickening and cheapening transportation; let it institute one new market or cajole one little band of genuine producers into dealings with consumers, and then it will actually prove of benefit."

I therefore present this resolution, which I very much hope will receive your endorsement.

"That the officers, who have presided at the Corn Show and the Agricultural Conference, form a committee of eleven to bring before the appropriate city department and the consuming public the means or possible method of taking some action towards bringing the farmer into better and closer relation with the city consumer."

While I recognize the informality of an endorsement such as you will give, I wish to say that if you will endorse this, it will be of extreme value towards carrying it to a definite conclusion. I see Dr. King here, who is an authority on these matters, and I know he has carried on some investigations for one of the departments of the city somewhat along these lines. Will Dr. King be good enough to indicate whether the appropriate department we would propose to approach with this committee would receive us with satisfaction, or would it be distasteful? An answer from you would probably guide us towards a closer solution. 
Dr. KING: I have undertaken several studies of giving help to the Philadelphia consumer, and every indication seems to point to the fact that a bureau such as the chairman suggests would be of inestimable value, if it did nothing more than give the farmer the information that the farmer wants in marketing his produce, and to get to the consumer some of the information the consumer would be glad to receive. I am very sure that any department that would be approached on this subject by such an assemblage as this would receive such a suggestion most heartily indeed.

Mr. Kates: Mr. Ross, have you anything to say in relation to this resolution?

Mr. Ross: I would like to carry something of that sort to my people. They are ready to produce, but they feel that the outlet for what they produce is hard to find. If such a step as this were taken in Philadelphia, I am satisfied that Philadelphia would be the objective point for the produce.

Mr. Kates: It would also serve New Jersey, Delaware and Maryland, as well as Pennsylvania and even a wider radius. I now will present this resolution and ask your endorsement to be indicated by raising your hand. I really feel that this is a somewhat serious moment, and if you take it seriously I trust that you will endorse it. I will repeat the resolution:

[Resolution again read.]

Does this resolution meet with your endorsement? If so, will you kindly express it by the uplifted hand?

[The resolution was unanimously adopted.]

Mr. Kates: I thank you very much in the name of all of us who have been concerned with organizing this conference.

Mrs. Smith: You will remember the allusion yesterday to the remarkable seed work being done in Denmark for the protection of seeds. I want you to know that Mr. Don Blair is one of the few men of this country who is carrying on, on his own hook and through his own endeavors, the seed-breeding work in Illinois. That is one of the most remarkable pieces of work being done along these lines in this country. It has been known to only a few people, but he is a man of great experience along these lines and has a remarkable work to show you this morning and has slides illustrating his work. I take great pleasure in intro. ducing to you Mr. Don Blair. 


\title{
INCREASING GRAIN PRODUCTION.
}

\author{
By Don Blair,
}

Sugar Grove, Ill.

There is but little question that the matter of increasing grain production is of vital importance not only to the agricultural public but to the commonwealth as a whole.

Our farmers in the Middle West, especially, have been exceedingly worried in the last few years, in the endeavor to make the owning of two and three hundred dollar per acre land a paying investment and to do this from year to year by practicing general farming. The failure in this has resulted in a widespread movement towards better farming. More net returns per acre tilled is the one thought uppermost in the minds of both the thinking farmer and his city cousin. This tendency towards better agricultural practice has become so widespread that it is being taken up by all classes, from the richest in the land to the poorest, and in no other period in the growth of this country has such an interest been taken in the farmer and his results.

Naturally there is the usual following of faddists and as a result, unfortunately, people of this class often occupy more of the limelight than the more serious, conscientious workman. Hearsay utterances based on plausible theories have done much to retard systematic development. Many theories have been built on a veritable foundation of sand and by constant repetition have been calmly accepted as proven facts. Thus, the farmer who ultimately tries them all out is becoming somewhat skeptical of things new. However, I believe that we are rapidly passing through this stage of theoretical fancies and are now reaching the second stage of agricultural improvement or that of practical common-sense bettering of conditions, based on proven facts. Consequently, there will be fewer theories advanced and more practical results obtained.

Increased grain production is essential and is comparatively easy of accomplishment. System is the greatest need. It is the little things that will make the difference. If the average farmer could have as clear an understanding of the business of farming as the manufacturer has of his business and, further, if the farmer would pay as strict attention to details as the same manufacturer, a wonderful increase in net return would be the result.

It is true that very little is known by the average farmer relative to the plants grown commercially on his farm; taking this as a department practically no attention has been given it as compared with the 
Livestock Department. We recognize that plant and animal life are identical and the laws that govern one must necessarily govern the other. We further believe that the chief object of the parents living is to produce offspring and to give these offspring a fair start in life. The simple little things have not been understood by the average farmer such as the flower, structure of the different plants, their method of reproduction and the interior structure of the plants. Such knowledge is in order that he may be sure of the adaptation of different plants to different soils and climatic coniditions.

I am very much afraid that we have been endeavoring to teach a more complicated system of practice before a systematic foundation has been established. We should start at the beginning with agricultural advice much the same as a child is started in the primary grades and not with the latest theories of any accepted authority.

The factors most essential in increased grain production are the seed, preparation of the seed bed, crop rotation and the chemical and physical condition of the soil.

The matter of seed: each variety must necessarily be adapted to the soil and climatic conditions where it is to be grown. Every condition favorable to the growth of the plant must be provided for and this can only be done from intimate knowledge with the qualifications and needs of the various varieties, as adapted to each and every kind of soil and climatic condition. In grains our variety classification at the present time is uncertain, one variety is found masquerading under any number of names with no system whatsoever. The farmer in the northern part of the country may be growing a variety of oats which he presumes to be the Swedish Select and adapted to his particular section but for some reason or another the variety he is growing will not produce successfully and upon investigation it may be found that he is growing a variety quite different from that which the name implies and not in any. way adapted to his conditions.

The first essential thing then in the matter of seed is a systematic classification of varieties. This classification when made should be published repeatedly and widely, together. with a complete description of each variety and the soil and climatic conditions in which it is best adapted. This is fundamental and no systematic development can be made until this is done. Allowing then that we have a known variety adapted to soil and climatic conditions under which we are operating and knowing further the weaknesses and strength of the particular soil on which the crop is to be grown, the first step is accomplished and next comes the preparation of the seed for seeding.

We have found from our own experience after repeated trials that the matter of grading seed is not of such great importance as many believe. While it is an important thing that seed be graded in order to eliminate weed seeds and immature grains, there is not the large difference 
noted in the relative productivity between the largest, plumpest kernels and the smaller or medium sized kernels of the same variety.

That which is most essential, however, is that the exact parentage of the seed be known, in other words, ancestry is of far greater importance than the relative size of the seed itself. The germ plays a greater part in the ultimate commercial worth of the plant than the amount of plant food contained within the seed. Therefore, while we like to plant nice large kernels, they need not necessarily be the plumpest or the largest, but they must be free from weed seeds. There is no use whatsoever in repeatedly planting the same weed seeds year after year, they come easy enough without planting.

The preparation of the seed bed should be given much attention; conditions differ, of course, in different parts of the country, but in the main the more finely pulverized, the more mellow the seed bed the better the chances of a maximum crop. Harrow and re-harrow repeatedly, for every harrowing will add to the crop.

The matter of seeding is also of importance. We have preferred using a single disk drill, although it is not necessary. Just as good results have been secured from broadcasting, but drilling will give a greater advantage in a dry season owing to a more even placing and covering of the seed.

The rate of seeding is essential; it is always our practice with oats in particular to plant rather thickly, from three to four bushels per acre. We do this largely to prevent stooling or tillering. Although large heads are generally secured on the stools, still the berry produced on the stool will in turn produce a weaker plant than the berry from the parent stalk and ultimately will result in deterioration of the crop from year to year. Further, by elimination of stools, early ripening, more even growth and a less proportion of by-product or straw, a greater proportion of salable product or oats is secured. We would much prefer the complete elimination of stooling if for no other reason than to secure a practically complete control of the crop. From so many berries planted of a certain germination so many plants will be secured and only so many, and the matter of uncertainty with reference to stand would be done away with.

With wheat we prefer planting from one and a half; to one bushel and three pecks and barley from two to two and a half bushels per acre.

One of the main difficulties with oats has been that plants are caught in the so-called milk stage by warm dry weather and the filling of the berry is seriously interfered with. But by using a variety adapted and planting early in the spring the plants will be over this stage before they are injured by the hot weather.

Crop rotation and intensive farming are as important as any other departments. It is useless to presume that we can secure maximum returns by continually cropping year after year without a change. One crop must follow another in such a way as to leave the soil in the best 
possible condition for the succeeding crop. This naturally varies with each section of the country but in its essentials is much the same all over. A cultivated crop should be followed by small grain and this in turn followed by a legume or nitrogen restoring crop.

Intensive farming can never be practiced until the acreage operated by the individual is cut down to smaller size. We try to farm too much by scratching it over rather than doing a little and doing it well.

As a matter of illustration of the results to be obtained from following carefully the above-named points I have in mind two farmers living side by side who this last year secured the same seed from the same source and one by "slipshod rule of thumb" methods secured thirty-two bushels of oats per acre and the other, a wide-awake up-to-date business farmer, secured seventy bushels per acre. The reason for the difference is simple and is accounted for from the systematic intelligent business methods of one as compared with a haphazard trust to Providence methods of the other. I could give numerous illustrations to the same thing but my contention is, merely, that the simple things, such as the seed, preparation of same, seed bed and condition of soil can all be easily governed by the individual operator and will make the difference between farming at a profit and farming at a loss.

One point that I wish to make most emphatic is the classification of varieties. This alone will result in astounding increase in production. Provided no other way for this classification could be evolved I would be in favor of placing it under government supervision and that no new variety of grain may be allowed introduction to the American public without being accompanied with a guarantee pedigree.

This same principle should not only apply to small grain but corn as well. The selection of seed, adaptation to conditions under which it is to be grown and seed bed are as thoroughly fundamental in this as in small grain and we cannot hope to secure maximum returns until a systematic form of educational campaign is carried on. The principles of instruction should be agreed upon by all known and accepted authorities. It is useless for a dozen theories to be advanced on the same subject by a like number of authorities. It confuses the farmer, as he is not in a position to recognize the standing of one authority against another and is more liable to follow the teaching of the wrong one. Those who have the little knowledge are generally the loudest in advancing their theories. It results in further harm by antagonizing the farmer against future development. We will take for example the rate of seeding, it does not require a diligent search to find every possible rate of seeding advised and after reading some of the suggestions it is difficult to believe that the theories are established on actual results.

Among other things incident to increased grain production is the seed plat. Every farm big or small should have a few acres set aside for growing the seed for the coming year. By this means it is possible to 
secure the very best seed obtainable and by looking ahead one year maximum production seed for the crop to follow is obtained. Change seed frequently. This year the seed patch may be used for corn, next year for oats and so on every year procuring a small amount of some kind of seed; thus keeping the seed patch constantly busy.

Seed should, by all means, be tested for germination before planting, not only must "test your seed corn" be a motto but test all seeds; this is the only way that we can definitely decided the rate of seeding.

Another great field for increased grain production and one which has been touched but little is that of plant breeding; from results so far obtained we can see a wonderful future to be accomplished by this work. Only a beginning has been made, the varieties now grown can be compared with scrub livestock and when one stops to consider the wonderful stride made in livestock breeding we can realize the future ahead for the plant breeder. With this in view, twenty years from now we will expect to see double the production per acre as now obtained.

The work of breeding for a convenience of classification has been divided into four divisions; namely, selection which is not in its truest sense breeding but is purely the selection year after year of heads or ears whether grain or corn with the idea to increase the productiveness of the particular strain grown. No blood lines whatsoever are interfered with and but very little progress can be made.

Second division is known as regeneration or breeding within a variety and consists of the selection of two strains of the same variety which have been grown under different soil and climatic conditions and combining the blood of these. The idea involved is that of regenerating the particular variety bred.

Third is known as simple crossing and is the crossing of two distinct varieties. Considerable improvement can be made with the practice of simple crossing. The results have been limited in favor of the fourth division or composite crossing, which is the infusing of the blood of three or more varieties into a single berry by a series of simple crosses. In the second or third generation from the berries so procured a maximum number of types are secured to select from by the breaking down of the blood lines of this multiple of varieties.

For example, we will start with eight varieties of oats the first year, we have four simple crosses and in the next stage two simples crosses and finally but one cross and the blood of all the original eight varieties are combined into the result of this last cross. By planting this any number of new and distinct types are ready for selection purposes. Breeding, once understood, is comparatively easy of accomplishment but takes considerable time and patience to produce results. However, bearing in mind again the enormous stricles that have been made with animal breeding, to say that plant breeding is worth while is to say but little. It will be but a short while until the plant breeder, given time, can fill almost. any order. 
In a brief résumé then, there are really three forms of increasing grain production: one is following the simple common-sense rules already known relative to selection of seed, seed bed, rate of seeding, etc.; second, of which little is known, is the improvement by means of breeding, but most important and our greatest need at the present time is system.

[The morning session at this point adjourned until 2 P. M.]

Friday, December 5, 1913, 2 P. M.

Honorary Chairman, Alba Johnson, Esquire, President, Baldwin Locomotive Works.

Mr. Johnson: Whatever draws the city and country closer together makes for the welfare of both, and also means for the farmer more money, for the railroads more traffic, and for the community lower prices.

The broader problems connected with the production, transportation and distribution of food products, will bring about more intelligent laws, and will conduce, therefore, to the welfare of both the producer and of the consumer.

That in a general way as I understand it is the underlying thought which prompts this conference.

The first speaker upon the programme for this afternoon is the Honorable Charles A. Prouty, of the Interstate Commerce Commission, who was to have spoken upon the subject of "Agricultural Freight as a Means of Rural Development." Commissioner Prouty is a man of such ripe knowledge upon the freight subject, pertaining to transportation, that it is a serious disappointment to us that his official duties in Washington, caused by sudden removal by death of certain members of the Interstate Commerce Commission, has made it impossible for him to be present, and therefore we shall not have the pleasure of listening to his address.

Chairman, Mrs. Smith: The first address of the afternoon will be one upon the subject of "Municipal Markets" by Hon. Cyrus C. Miller.

Hon. Cyrus C. Mrluer, Chairman, Mayor of New York's Committee on Municipal Markets and President of the Borough of the Bronx: I propose to talk to you on the subject of "Municipal Terminal Markets," amplifying the thought that our intensive farming, and the larger areas which are now planted with fruit trees and crops, foretell a very serious danger not only to the people who are doing the planting but to the people in the cities who ought to get the results of what is planted. In other words, we are threatened with overproduction unless we increase our terminal and distribution facilities, as well as our production.

I shall be very glad to answer any questions if time allows after I have finished my address. 


\title{
THE NECESSITY FOR TERMINAL MARKETS.
}

\author{
By Hon. Cyrus C. Miller, \\ President of the Borough of the Bronx; Chairman of the Mayor's Market \\ Commission of the City of New York.
}

A witness before the Mayor's Market Commission of New York City recently testified that there were enough peach trees in the orchards of western New York to produce a crop of 10,000 carloads of peaches in five or six years. Fifteen years ago Delaware shipped out 9,000 cars of peaches in one year and a few years ago Georgia shipped out 7,200 carloads.

In a recently published newspaper article I read that the apple crop in the Northwest for 1913 was approximately 10,000 cars of fruit; by 1916 they estimate that the output will be at least 30,000 cars, and by 1920, a total of 60,000 cars. At present prices this will mean finding a market for $\$ 51,000,000$ worth of fruit. Other districts throughout the country during the past ten years have been planted in large areas with fruit and other food products which must be distributed among the cities and towns. The population of the cities has grown apace in the same period, but their markets have not kept pace either with the increase in production nor the potential increase in consumption. Producers' associations, railroads and middlemen are effecting the best distribution of crops possible with the means at their command, but in the cities the best means available today are the makeshifts that survive a simpler system. There is a great necessity for modern terminal markets if the distribution of food products in the cities is to be helped. What is the use of raising vast quantities of foodstuffs if they cannot be distributed? Bankruptcy confronts owner and consumer alike unless our distributing facilities keep pace with our production. The farmer, the banker, the railroad man, are interested in the first part of the problem; namely, getting the food to the cities. The city man is interested in bringing the food into and distributing it within the city.

The question of city markets is a vital one not only to people in the cities but also to the farmers of the country, for all production must have an outlet or it ceases to be profitable, and cities must be supplied with food at reasonable prices or cease to exist. In many cities today the channels of marketing are so badly clogged that they offer obstacles rather than inducements to shippers. On the other hand, we hear constantly of good food spoiling on the farms of the country because it does not pay to market it by our cumbersome and expensive methods. 
The railroads of the country are confronted with a constant increase in freight traffic for which they have great difficulty in providing the necessary terminal facilities. A report of the forty-nine railroads of the northeastern section of the country, published in the New York Times of December 4, 1913, says that between 1903 and 1912 "railway traffic, both freight and passenger, increased much faster than the facilities for handling either. . . . The freight traffic increased 53 per cent, and the passenger traffic, 42 per cent, as compared with an increase of 17 per cent in population," of the section served by these lines. In 1903 these roads were operating 55,706 miles of line. From 1903 to 1912 they increased their mileage $6 \frac{1}{2}$ per cent and their double trackage, $15 \frac{1}{3}$ per cent. Daniel Willard, president of the Baltimore and Ohio Railroad Company, in commenting upon the situation said, "The immediate and all-important question is: How shall these railroads obtain the new capital necessary if they are to provide the needed facilities and furnish the high-class service which the public interest demands, and to which the public is properly entitled?" In the distribution of food products to the cities, in which the railroads play so large and so increasingly important a part, it is not only a question of the "service to which the public is entitled," but of pressing public necessity, that there should be in the cities terminal marketing facilities for the receipt and speedy distribution of foodstuffs.

The interest of the city in terminal markets is identical with that of the country and the railroads, the function of a proper market being twofold-to distribute foodstuffs within the city, and to encourage the growth and transportation of foodstuffs to the city. Unimpeded distribution to and within the city will cause greater consumption of food products because prices will be lower. It will encourage the farmer to produce more because he is sure of a good market. The unit price of what he sends to market will be lower, but there will be no waste and the aggregate return for the larger quantity grown will net him a larger profit.

One of the greatest benefits of good markets to the farmer will be that they will change his occupation from the hazardous guesswork it is now to a steady business at moderate prices upon which he can rely. It is of no benefit to a farmer to get a high price for a part of his crop and nothing for the rest of it. It will pay him better to sell it all at a comparatively low price. With the hit-or-miss methods of marketing now in vogue, a farmer must guess from year to year whether his product is to find a ready market or whether there will be a glut or whether there will be a scarcity. His business is speculative in the extreme. On the other hand, if the demand could be estimated and supplied through adequate distributing facilities, the danger of gluts would be minimized greatly.

Our recent studies of market conditions in New York have disclosed the fact that the city draws its supplies from world-wide sources: for instance, potatoes, from various parts of this country, Scotland, Ireland and Belgium; onions, from our own farms, Bermuda, Italy, Spain and 
Egypt; oranges, lemons, melons, cherries, etc., from California, Florida and other states, the West Indies, and Mediterranean ports, and so on. And it is more or less the case with every large city of the country. As an example of conditions, Mr. Frank Andrews, of the United States Department of Agriculture, states that in 1912 Kansas City's lettuce supply was taken from nearby fields, from California, Florida, New York, Louisiana, Colorado, Texas and Arkansas, and possibly other states.

The initiative that the railroads take in widening the distribution of crops is perhaps not generally appreciated. They do a useful work in finding new markets for producers, even going so far as inducing merchants in cities to import new commodities. An increase of distribution of North Carolina strawberries was made, from 400 cars to 12 markets in a year, to 3,200 cars to 82 markets, nine years later, due chiefly to the initiative taken by a railroad in suggesting markets and helping to widen the distribution of the crop. 'It is of course to the railroad's interest to do this, but it is equally to the interest of producer and consumer.

Because of the insignificant supply of foodstuffs grown in the vicinity of New York, that city is perhaps an extreme example of a city which depends altogether upon distant sources for its food supplies. Other cities are supplied to a greater degree by nearby products, but it may be stated as a rule that all American cities depend largely for their supplies upon distant sources. This may be because of location in an unproductive area, or a short season of local production, but chiefly because all American cities demand a greater variety of food than the local area can produce.

The possibility, which is of comparatively recent development, of shipping highly perishable articles under refrigeration, by fast freight, to distant markets, has lengthened the seasons when vegetables and fruits are in market. The farm produce of South Carolina and Kansas can reach New York as easily today as could that of Long Island and Westchester County a few years ago. There was a time, as was stated by a witness before the Market Commission last spring, when the season in New York for strawberries was only six weeks long. Now we start in with Florida strawberries in February and have them until the middle of July from northern New York. In July the same cars after refrigeration are taking berries south from northern producing states that in May were taking them from North Carolina to those same points. Such things as string beans, tomatoes and lettuce are in market practically throughout the year.

With the shipping of perishable goods long distances by rail, the carload has come to be the recognized shipping unit, because of the ease of handling unbroken carloads with dispatch, as compared with less than car-lot freight. Mr. Andrews has collected data from 42 cities showing that from 1900 to 1910 there was an increase of 40 per cent in the number of car-lot markets for highly perishable fruits and vegetables. "Practically every city in the United States," he says, "of 25,000 population or more, 
and possibly many smaller ones, can consume within a few days a carload of one or more kinds of highly perishable fruits or vegetables. According to the report of one of the large merchant shippers of Jacksonville, Florida, in 1912 car-lot shipments of Florida produce were made to 210 different cities, located in 46 states. This number includes most all of the cities of this country having a population of at least 25,000 ."

This being so, it may be seen at a glance that the real problem before the country today is not so much the growing of foodstuffs as their economic collection, transportation and distribution. In some ways the development of good methods of cultivation has already gone ahead of the development of good methods of marketing. From the moment the goods are placed on board the cars or boat, the question is one of distribution. In most of our cities the distribution of foodstuffs is primarily a railroad question, so that the market best fitted for the assembling and marketing of provisions in the city is the wholesale railroad terminal market, into which and out of which run as many railroad lines as possible.

Such markets should be large in size so that there will be provision for a considerable expansion of the present trade, and so that as large a number of buyers and sellers as possible may meet in them. They should be supplied with refrigeration, so that goods arriving in refrigerated cars may not suffer from exposure to harmful temperatures, and so that surplus may be kept without deterioration. They should have ample unloading platforms and storage space, as well as exhibition and selling space. In each market one or more licensed city auctioneers should be stationed to dispose of goods consigned directly to the market.

The object of any market should be to facilitate distribution by bringing producer and consumer a step closer together, and though the form of market may differ widely according to the conditions in the city it is to serve, the principle of the thing is everywhere the same: the best type of market for any city is the terminal market, adapted to the nature of the carrier which brings the food products, whether such carrier be farm wagon, freight trolley, railroad or boat. The market at the terminal makes for the elimination of waste in handling and for a better articulation of all the processes of distribution. Such a market in a city should be in the control of a market department or official, to publish daily bulletins of the quantity, quality and prices of foodstuffs in the market and in other ways make the system efficient.

It must be recognized that the best methods of marketing our crops requires the co-operation of our farmers, shippers, railroads and market men. No one of these forces, no matter how well organized, is sufficient in itself to effect the desired end. The Federal Government has realized the necessity of the co-ordination of these various forces. 'The last session of the Sixty-second Congress made an appropriation of $\$ 50,000$, of which $\$ 10,000$ was available immediately, "to enable the Secretary of Agriculture to acquire and to diffuse among the people of the United States useful 
information on subjects connected with the marketing and distributing of farm products, and for the employment of persons and means necessary in the city of Washington and elsewhere."

At a meeting held in the Department of Agriculture on April 29, 1913, Mr. G. Harold Powell, general manager of the California Fruit Growers' Exchange, made the following valuable suggestions for the work of the department:

"(1) Determine the principles on which farmers' business organizations can be successfully founded and operated.

"(2) Work out the principles of law which should be incorporated in state and federal legislation and which would permit the proper organization and conduct of farmers' associations.

"(3) Study the distribution of farm crops as practiced by farmers' organizations and other agencies in order to determine the weaknesses, the wastes in distribution, the abuses and extravagances of the distributing system, and illegal practices, if such exist, and as a result set forth the principles of state and federal legislation which would define the functions of the various distributing agencies, correct such abuses as legislation can reach, define and set forth the principles of co-operative organizations, and assist the farmers in the formation of their organizations.

"(4) Help the farmers after they are organized to develop a system by which they can secure for themselves better information regarding crop conditions, the movement of crops, the supply in different markets, and the daily prices, this information to supplement the general data which the department may furnish the public.

"(5) Investigate the methods of handling, grading, packing and preparing farm crops for market, to bring about a greater uniformity and to correct the abuses which now cause a large proportion of the trouble in the dealings of the producer with the distributing agencies."

When this is done the work of co-ordinating the forces outside the cities may be said to be under way. Important as this work is, it must fail unless the distributing facilities in the cities are co-ordinated so that they may take care of the produce which the farmers send to them, without uncertainty, waste and loss.

Producers' associations are likely to be successful where the country in which they operate produces a single staple crop, their efforts being to market their products and to see that they are graded and packed properly. It is somewhat difficult for a producers' association to flourish in a locality where many different sorts of crops are produced. It might be well, therefore, for studies to be made in different localities for the purpose of finding out the most profitable crops for the neighborhoods and urging the farmers to confine themselves to them. Co-operative associations among the consumers in the cities have not been very successful in this country because of the individualistic tendencies of the people, which prevent them from co-operating easily, and the fact that cash payments are displeasing to 
many of our city dwellers. Nor does it appear necessary that there should be co-operative buying in the cities if proper facilities can be given in the primary wholesale markets to the retailers who do the final distributing.

The increased cost of food is causing alarm, and there appears to be no likelihood that meats will decrease in price for some years to come, if ever. This will necessitate a greater consumption as time goes on of farm produce. The danger will be, unless means are taken to distribute all that is raised, that there will be over-production and consequent gluts. The Secretary of Agriculture has suggested that the market service in the Department of Agriculture should include a "marketing news service, the work along this line for the time being to consist mainly of an investigation of the practical methods and cost of conducting such a service, and later, if found feasible, to include the daily collection and distribution of information relating to the supply and demand in the leading markets, progress of planting and area planted, and condition of growing crops." Such information cannot help but be of the very greatest value as it will tend to curb over-production and at the same time point to new channels of consumption. The farmers must aid the work by skilful growing of crops and through proper grading and packing for the market. The railroads and boat lines must help by quick and cheap transportation. The cities must help in the first place by the primary wholesale terminal markets, and in the second place by scientific methods of transportation and distribution within the city after the goods have left the primary wholesale markets.

Mrs. Sмітн: We are anxious to have the gentlemen present take part in discussion with Mr. Miller. You have before you one of the most expert men along this line in the country, and we would like to have all take part who wish to.

Delegate: Why can't we have a larger distribution in a market like this?

Mr. Miller: I don't know of any marketing city that does not suffer from lack of proper distribution. There should be an opening up of the channels of trade and the making of a central marketing place whereby parties furnishing products could come, but I do not know of any such place. Last winter in one section, cabbage was selling for 3 cents a head, right on one of the town's streets, and yet the people in the adjoining block didn't know it was in the market. If there was a regular center there where the housewife was accustomed to look for any particular supplies this condition would not exist.

DeLEGATE: Where information on quotations is not available on the various market products, where can we be informed? 
Mr. Miller: By our bureau service. He can subscribe to it and get what information we have.

Delegate: But maybe they won't subscribe.

Mr. Miller: I won't say they will, but if the housewives were anxious for that information they would get it. But the supply now is too uncertain. You can never look forward to getting certain supplies cheap this week and cheap next week. There must be a variation. We have onions raised in Orange County, two hours distance by passenger train, and it takes a freight car eight to fourteen days to get in a lot of onions from Orange County. A dealer told me last year he tried the experiment of putting baskets of onions in retail stores at five cents a basket; because the consumer hadn't any idea they were coming into the market they did not meet a ready sale. In other words, their eyes were not attracted to it, and you must keep things before the consumer constantly if you want to make them buy.

\section{Delegate: How are you going to regulate that?}

Mr. Miller: By studying the supply. The housewife will do that herself. As it is now, we have low prices this week, high prices next week, and she doesn't know what she is going to do, and even the retailer doesn't know what he is going to do.

DeleGate: Recently on account of the weather we have had poultry go bad, probably one or two birds in a box, and the rest salable. How would the Municipal Market handle that?

Mr. Miller: You would have an inspector for those who would determine whether they were fit for food or not.

DELEGATE: Instead of condemning it he would sort out the bad and sell what was good?

Mr. Miller: Yes.

Mrs. Sмітн: There are so many here who know something about this part of the discussion we would like to have all of you take part.

Delegate: Why is a carload lot necessarily the unit?

Mr. Miller: For the reason you can get better freight rates with carload lots than a fractional lot.

Delegate: What is the difference in carload lots and fractional lots?

Mr. Miller: It depends on the distance and the amount you carry. It is different on different railroads.

Delegate: That is the key to the whole situation.

Mr. Miller: I think we will both agree there is a difference in freight rates.

Delegate: Yes, and in numerous instances unjustifiable difference. 
R. C. Wright: If this gentleman will call at Broad Street Station we will discuss the matter with him.

Mr. Miller: I think we will agree there is a difference in the rates. I think it is up to you farmers to send in carload lots wherever you can. Why not get together on it?

Delegate: I think it is better for you to get into your cities what they are trying to get in the town of Boston where you have a freight delivery from house to house.

Mrs. Sмттн: We have some representatives here from railroads. How about Mr. Wright?

Mr. WRIGHT: I was just going to ask this gentleman to talk on this subject if he will talk statistics. Carload lots and less than carload lots are two different phases of the question, and you get nearer the truth when you take it on that basis. I hand the gentleman my card and hope he will come over to see me.

Delegate: I am not a railroad man now, but was for a number of years. I am connected with the Chamber of Commerce in Baltimore. Our friend who has spoken here doesn't look with approval on the difference between rates in carload lots and less than carload lots. I was very sorry to hear at this conference one word of criticism on railroads, about the question of freight rates, but it all came merely through Mrs. Smith alluding to the fact that it took a long time to make some rates. And it does. The railroad traffic is a very delicately adjusted affair, and anything that looks to the better serving of its patrons and better revenue. would be done tomorrow, and adversely, such criticism cannot but help having a most deleterious effect on the community, besides. Railroads have their limitations and they must at all times act with care and caution as to what will be for the best interests of the railroads themselves and the people whom they serve.

There are unfortunately, usually one or two kickers, and a disposition to criticise the railroads for what they do, but they have not a clear understanding of the limitations and reasons of the railroads. But we are now getting closer and closer to the proper relation between the carriers and their freight patrons, and the producer and consumer. I wish I had time to give you many specific illustrations of the many, many improvements in service the great railroad carriers have added towards the communities they serve. They are anxious to have them prosper. As an illustration I would ask you to see the magnificent exhibit the Pennsylvania Railroad has, of its efforts along this line here in the eastern cities. They have industrial agents. They are doing everything they can to build up the country, and why shouldn't they if they are to benefit by it and it is the wisest course to follow? I know in my long railroad service criticism is bound to follow no matter what you do. If you do a thing one way you are blamed for it and if you do it the other way you 
are also blamed, and I believe, in a meeting of this kind, we should approach this question of transportation fairly, honestly and unbiassed and impartially, before criticism is made, and I am frank to say that I believe nine hundred and ninety-nine out of the one thousand instances of complaints that are made, could be satisfactorily explained by the railroads.

Mrs. Smith: Mr. Nathan, of the Pennsylvania Railroad Company, is here and will speak to you for a while.

Mr. Nathan: This is rather a surprising call, as I was not on the programme, but I am always glad to speak of our efforts in behalf of the milk question. I have been very much interested in the discussions at this conference as far as I have been able to attend, and I want to take the liberty of saying I was somewhat disappointed last night in seeing the subject of milk handled as it was, and possibly there was a great deal of misinformation spread among those who were present as to the care and effort which milk dealers, like those with whom we came in contact last night on the stereopticon, are claimed do not exercise. Most milk dealers are deserving to a degree and understand the care and quality of milk. It is unfortunate perhaps that I didn't say this last night, although the hour was very late. It is unfortunate that the conditions existing as shown, would be such as they are, or that they would be permitted to conduct the milk business in such a way, and if they still exist the city authorities of Rochester ought to take some method or measures of overcoming it. But it isn't true. At least we haven't found it so, if those conditions were stated to be facts as being conditions typical in every large city in the United States. As a matter of fact, in the cities of New York, Baltimore, Philadelphia, Washington, and more especially in New York and Philadelphia, as he tells us there have been spent hundreds and thousands of dollars in plants calculated to put milk on the market in the very best condition. It may be true, as it no doubt is, that in every city there are some undesirable milk dealers, but on the whole every effort is being made to raise the standard and quality of the product to the greatest maximum possible, and the methods we are perfecting in large cities for handling milk, as well as in the country, run into the hundreds and thousands of dollars. Since the organization of the Milk Bureau there have been plants on lines of the Pennsylvania Railroad, and particularly on this entire system, whose value exceeds one-quarter of a million dollars, and would before the end of 1914, or at least when the plants are finished, be worth half a million dollars in real estate and equipment. These enterprises are spending these vast sums of money in the country to secure a good product and our railroad company is spending a large sum of money daily, weekly, monthly and throughout the entire year, in service which is calculated to place this milk at points of consumption in as good condition as it is possible to do that. We have inaugurated service starting at the city of Buffalo at 7 o'clock in the morning, picking up milk within a 
distance of twenty-seven miles from Buffalo, connecting with Philadelphia and New York and various towns along the line until it reaches to the extent of eighteen cars. Much of that milk is for Philadelphia and New York. We deliver our milk in Brooklyn, through the tunnels under the East River and under the North River to Manhattan. Milk shipped 8 o'clock this morning is in Brooklyn at 1 o'clock, and on the tables at 7 and 8 o'clock the next morning. To accommodate this traffic we have equipped ourselves with steel refrigerator cars, well constructed. Refrigeration is secured by the salt being put into tanks at the end of the car. We can demonstrate to you that the temperature is $36-37$ degrees now existing in those cars at Broad Street Station and can be maintained at that temperature for forty-eight hours without re-icing.

I might mention an incident connected with this railroad. It has been the custom of all milk operators to place their ice directly on the cans and bottles. We consider our system is a great improvement, as in that way it does not bring the ice in contact with the milk in any way. If you ice it the old way and ship it in cases, these bottles are covered with cracked ice, which brings it in close contact with the milk, but separated from the milk by the cap on the bottle only. But in this particular refrigeration system we have, this last method is entirely unnecessary but we have considerable trouble to convince the dealers it is efficient, and one dealer in New York City has been skeptical of our efforts, until the other day we received a letter to the effect that their entire shipment from Williamsport arrived in Brooklyn frozen, and after an interview we instructed our people not to use so much salt, as the milk arriving in a frozen condition is unsalable. It, however, convinced the people of our system of refrigeration, and they had no further complaint.

I don't know that I can say anything further, except that our activities are well understood along this line at every point, and if there is any one here who is in the dairying business, we are glad to confer with him and glad to see him at this conference and hope you will all take advantage of seeing our dairy and agricultural cars in Broad Street Station, and on your way out of this conference you can procure one of our pamphlets explaining to you about our agricultural work.

\section{Delegate: What are your rates?}

Mr. Nathan: Our rates are standard rates established some years ago by the Interstate Commerce Commission and maintained by all lines on a parity with New York and Philadelphia.

Mrs. Sмiтн: We will now hear from Dr. Pennington. I want to say here, that Dr. Pennington has a remarkable personality because there are few people who are pleasant to everyone, and in Washington they tell me she is one of the ablest women they have, and think a great deal of her. She is not going to speak on the laboratory or cold storage, but railroad co-operation this afternoon, for she is of the impression we have a pretty fine system in this country if we only make use of it. 


\title{
CO-OPERATION OF RAILROAD TRANSPORTATION OF PERISHABLE PRODUCTS.
}

\author{
Dr. Mary E. Pennington, \\ Director, Food Research Laboratory, Bureau of Chemistry, \\ United States Department of Agriculture.
}

The day of the farmer's market wagon is passed. The broad zones of suburban residences surrounding our cities preclude extensive food production within feasible hauling distance of the market. Here and there a small gathering of wagons dispense goods to a limited section of the town, but as a source of provender for the city's population it is of but small moment. We must depend upon steam or electricity to bring the food supply from the region of production to the region of consumption, and the producing center for this eastern country seems each year to be more remote. Even what we term "nearby produce" must come by rail; therefore, the farmer as well as the consumer is dependent upon the railroads.

This traffic in the transportation of perishables has grown with startling rapidity and has far surpassed in volume and efficiency any precedents furnished by the old world. Its very newness and strides make for unrest, because conditions are changing with such rapidity that neither the shipper, on the one hand, nor the carrier, on the other, can continue one mode of business long enough for the methods involved to become perfected by routine use and the unconscious absorption of details by the human part of the machinery involved. There is a very detrimental amount of ignorance on the part of both shipper and carrier concerning their respective business. This is partly because the whole subject of the handling of perishable products has been neglected until recently, when the pinch of high prices has made us look for wastes and extravagances.

As a part of the investigation of the handling of perishables, the United States Department of Agriculture has been studying, co-operatively with the railroads, how foodstuffs can be best and most economically transported. This is not a problem that can be worked out at the office desk; neither do experiments with small quantities and prepared conditions suffice. The goods must be by car-lots and the observations must cover hundreds of routine shipments, month after month, that the influence of seasonal weather and seasonal freight may be taken into account. Because refrigeration plays so important a rôle in the preservation of foodstuffs, a large part of the work of the department has been to 
determine the temperatures prevailing in refrigerator cars in transit and what temperatures are necessary in order to transport the goods in prime condition. The department could readily provide instruments which would give a record of the temperatures prevailing throughout the entire haul, be that long or short; but it was necessary to know also the construction of the cars, their insulation, bunker system, icing methods and a hundred and one details that could be obtained only with the co-operation of the railroads. This matter was, therefore, laid before railroad after railroad as the work extended, and in every case it has met with universal courtesy and a willingness to give the help or privileges asked.

We have taken long journeys on freight trains in company with the carload of the perishable product under observation. Every agent in every yard has been notified by the railroad officials of our coming and has done all in his power to make the trip profitable and the observers more comfortable - not an easy matter, when running through a blizzard or on a fast schedule. We have also been made welcome in every freight yard, transfer station, dock, pier and terminal, and every facility in the possession of the carriers has been put at our disposal.

We have in this way gained an intimate, first-hand knowledge of the problem of transporting perishables from the railroad viewpoint; and because we have studied with the shipper or producer every detail of the origin and preparation of the product to be shipped, tracing it step by step to the consumer, we have absorbed his point of view also.

We have found a woeful lack of a mutual understanding of the difficulties confronting both parties. Each is ready instantly to disclaim responsibility and to place blame on the opposite party. Such a condition of affairs can only work hardship to all concerned. Litigation is a far greater expense to the nation than the money actually spent indicates, because it seldom results in fundamental reforms, and many of the conditions which the decision is expected to remedy remain practically the same. The fact that very frequently the well-being of the railroad makes for the success of the shipper, and vice versa, is too often lost sight of.

Without in any way trespassing on either the peace commission or the judiciary, we have had the satisfaction many times of seeing mooted questions between railroads and shippers clarified and more efficient work done as a result of the knowledge gained. This principle has progressed to such an extent in the poultry, butter and egg industry that a joint committee has been appointed by the shippers and the railroads to discuss transportation problems in their broadest sense, to acquire information and to encourage more intelligent packing and handling, that losses all along the line may be avoided. A representative of the Department of Agriculture meets with this committee in an advisory capacity, thereby keeping its work in touch with the newest findings of the department. From time to time the committee issues reports which are published in trade papers as well as separately. 
The work so far has been very largely on the breakage of eggs in transit. The general investigation has been undertaken by the department, through the Food Research Laboratory of the Bureau of Chemistry, co-operatively with this committee and the industries which it represents.

The investigation of such a question as the breakage of eggs in transit would be an impossibility without co-operative work. No amount of detective ability.would compensate for the free opening of records and frank statements of facts that are ours for the asking. Of necessity we receive many confidences that never go beyond the laboratory staff or the laboratory files. Our success depends on respecting such confidences. It is our custom to take the results of our work back to the shippers or the railroads individually, if they are directly applicable to individuals, just as promptly as they become facts. Later they are available to all parties in a publication which is strictly impersonal.

Whatever activities this committee may undertake, it will always be of great value as a clearing house for questions and a promoter of a better understanding between people who are gradually learning that, when all is said and done, the greatest good is mutual good, the surest progress is mutual progress.

We realize that anything which undertakes to bring about railroad co-operation is skating on pretty thin ice. Perhaps, however, the ice is fixed for Uncle Sam because we have no axes to grind and therefore can hardly be accused as a party to that. This question must be worked out along practical lines, as Mr. Miller has ably laid out in his statement concerning market terminals.

\section{Delegate: How long does meat keep in cold storage?}

Dr. Pennington: We do know it will keep at least. a year. How much longer than that we don't know.

Mrs. Sмітн: A gentleman told Dr. Pennington he always froze his turkeys and kept them at a temperature of three degrees below zero. Dr. Pennington said, "Take them out and keep them at a temperature of sixteen above." I thought that was a good point, because the BellevueStratford and other such well-known hotels are glad to have such information from such good authority.

Delegate: Don't get Dr. Pennington started on the cold-storage question. She is going to talk on that subject later.

Dr. Pennington: I fully intended at the time the carload lot discussion was on, to say something, but I forgot it. Not on the subject of rates, but on another question quite as important. It is of just as much importance to the nation to get products from the farmer to the consumer in good order - every single egg, every head of cabbage or whatever it may 
be-as it is to have a rate which is favorable to the shipper or consumer or whoever may be interested in rates, because if you do not handle your goods under proper conditions and deliver them to the markets in good order, there is no doubt but that the expense all along the line will be increased, notwithstanding any effort you make to adjust the rates. We also know from the experience gained in our work in the department at Washington, that maximum efficiency can be better attained in the handling of products in carload lots. It is even hard enough handling it under that method, and I think every railroad man will bear me out in that statement, and those who handle refrigeration will say so too. But to do it on the odd lot basis, a few cases here and a few barrels there, one sort of package here and another there, with nothing fixed, nothing uniform. How can you do this and bring your products in to the markets in good order? We are a higgledy-piggledy disjointed nation in the matter of distribution of food supplies. We must learn to do it better. I do not know in just what direction we are going to develop in this matter. Take such a period as we have just gone through in our Thanksgiving market, where our poultry came in by tons unfit for use; and during last summer when in the big poultry-producing territory south of the Missouri and along the Mississippi we had a loss, an actual loss, of thirty-five per cent of the eggs that were produced, representing a loss in money hard to estimate, and which conservatively estimated during that period would amount to $\$ 12,000,000$. That sort of waste we must take steps to stop.

We do believe that the carload-lot unit is a means of stopping a great deal of this waste. But you cannot keep a car cool-and refrigeration is a prerequisite in the handling of a great deal of our shipments-you can't keep a car cool if you open the door at every station and put in something that is hot. You have to start out with your carload cool and keep it cool. It must be done efficiently, whether carload lots happen to agree with our own particular ideas or methods of doing business, is quite aside from the national question. The national question comes first, for whatever is best for the nation is best for us too.

Delegate: If you can keep meat for a year, as you have said, how long can you keep milk?

Dr. Pennington: I never tried it. Do you mean for $a^{\bullet}$ short or long period?

Delegate: Is there any method of keeping it until carload-lot quantities were had?

Dr. Pennington: There are ways of doing that by co-operation among the farmers. Up until now it has only been a possibility, but in the future it will be a reality. Then we will ship such articles as milk by carload quantities.

Mrs. James (of the Civic Club, Philadelphia): Is there any known method of taking care of small shipments? I know a great many farmers 
around who are giving away their surplus products because they have no way of shipping at a distance twenty miles. from the city. For instance, if I want to ship a basket of apples for that distance it becomes too costly. Isn't there some way of handling that produce from the farmer to the consumer so that he would receive a certain amount of money for that rather than giving away their product?

Dr. Pennington: I would consider going to the neighbors who give away their excess produce, have some method of collecting the excess material they are giving away, then see your railroads and try and get together and talk the matter over and see if you can get those who are giving away their products to handle it to the advantage of all. For my part, I do not believe in asking a railroad to haul a quart of milk or a basket of apples or anything like that. They can handle a carload of apples with much greater efficiency.

Mr. Reynolds: I was going to answer the gentleman's question regarding milk. I had some experience in the milk business. A customer complained about the milk because I was delivering milk in the morning that was milked the night before. I gave him two bottles of milk, one a week old and one the morning's milk, and he couldn't tell me the difference. He kept on testing it, but he chose the oldest milk as being the fresh milk. If you will keep milk at a temperature of forty degrees, you can send it from New York to Japan by way of San Francisco, and that has been done to my knowledge. But there is one thing I believe should be seriously considered. I happen to know some farmers who have gone out of business because of this experience: They put their milk on the railroad at under fifty degrees and it is landed in the city at over seventy degrees; the milk is inspected, thrown out and the shipper foots the bill and the railroad doesn't do a thing as a result of that sort of method, just as if the milk was thrown in the sewer, and the farmer loses it. $\mathrm{He}$ paid his share also to the railroad and he has no come-back.

Delegate: It seems conditions are changing. We need refrigeration now, but didn't need it or didn't think of it ten years ago. And we are paying for refrigeration but don't get it. We get an attempt at it, but inasmuch as it is impossible to successfully keep the temperature down at all times of the year, why should we pay for it? We are charged with refrigeration rates, yet it is impossible to get it, and we shouldn't be charged refrigeration rates if we don't get the service. If we got any benefit out of it or if our milk was helped we would pay it. Unless conditions change it means we must go out of business. In my own territory, which was formerly a milk-producing territory, we must either change our occupation or do something else.

Dr. Pennington: The railroads are undoubtedly trying to handle your product in such a way as will procure not only for you but for them- 
selves the maximum efficiency, and they are no doubt endeavoring to give you the best service.

Delegate: We have been charged refrigerator car rates for six months and there hasn't been any ice in them, and we pay the same charge as when there were no refrigerator cars.

Dr. Pennington: You are so close to the Interstate Commerce Commission I believe you will have to go to them about that. All our shipping questions have their problems. They are hard knots to unravel and the railroads as well have their tangles. These are knotty knots and which side of the fence are we going to be on? Maybe we are all wrong in this matter, but let us do the very best we can. We honestly think this work we are doing in the matter of investigation should be carried out along this line as to methods of doing it, then take that information to work out a system for production and distribution, to give the very best thought on the subject that we are able to give. That is what the Agricultural Department must do now to help us in this food problem. What to do with that information is right up to you. We are doing the very best we can and the very best we know how, to get the best results.

Mr. Yearsley: We have it on the authority of H. B. Fullerton, also on the authority of Professor King of the University, that there exists a systematic destruction in throwing away produce, on the railroads on the way to the big cities. I would like to know to what extent that has been and what the government has done towards investigating it.

Dr. Pennington: So far as the work comes under our supervision and so far as we are concerned, we have never made any nor do we make any investigations. I don't know anything for or against that question.

Delegate: Assuming a poultryman in Texas wishes to provide for his shipment to the eastern states, would that probably be by co-operation with the railroads?

Dr. Pennington: Do you mean what we are doing with regard to a shipper in Texas?

\section{Delegate: Yes.}

Dr. Pennington: We have gone down into the storage districts. Sometimes we have put our inspectors into packing houses to work with the packer to show him how to kill his poultry, to load his car and get his stuff out. We have a department connected with that where practical men who are looking after this phase of the work are engaged in the producing sections all the time. Just now this "field station" is down in Missouri. It has been in Kansas, Iowa and Tennessee, going from one packing house to another, answering questions and demonstrating the 
work, how it should be done. When the car is loaded and registered, a thermometer is put aboard and the car is shipped through and met by one of our own men at its destination, wherever that may be. When the car is opened we look at the goods tested under very definite conditions at the shipping point, and we take the report of the thermometer.

When we look back four or five years at the general methods of handling our products and compare them with the general methods we have today, there is a general big improvement. The National Poultry Association in 1909 had a meeting of about ninety members where much interest was shown. At their meeting last year there were three thousand members at that meeting and they are working for good ends. This kind of interest is being shown all over the country. It means we have to handle our products better all along the line, and the department, both state and federal, has to send its men out into the highways and byways, out among practical men and take the scientific work they acquire in the laboratories and experimental stations to the people who are actually using them. That is what we are trying to do.

Mr. Kates: What did the gentleman understand who spoke a while ago as to Dr. King's article?

Mr. Yearsley: I have in my desk a written report that Professor King wrote on markets of Philadelphia, in which there is the statement that there is a systematic throwing away of produce in the city, in order to maintain prices.

Mr. Kates: The sense of that, I believe, is that the railroads throw away those consignments only under instructions from the shipper and is not a destructive interest on the part of the railroads.

Mr. Yearsley: I didn't say a word against the railroads.

Delegate: I would like to ask if you can realize how hard it is to get together with the railroad company. We farmers in South Jersey have been shipping goods to Philadelphia and New York markets that take two hours to reach. These goods are ready between three and five o'clock in the afternoon, and have to be here by one or two o'clock the next morning. Frequently these goods don't get into market until between five and six o'clock the next morning. Of course the market is over then and each individual farmer may lose from $\$ 10$ to $\$ 50$ on his shipment. We take that up with the railroad company and all the satisfaction we get is that the shipment was delayed. And you have no redress. They say they can't get it in there. We farmers try to get with them, but we get no satisfaction out of them. They say, "If you can't get them there by freight, ship them by express."

Mrs. Smith: We know that is the crying evil. We would like to hear from Mr. Horne. 
COLD STORAGE.

Frank A. Horne, Esquire,

President, Merchants' Refrigerating Company, New York City.

Before beginning a discussion of the topic assigned to me, I desire to succinctly state a few facts concerning the present agitation touching the relation of the refrigerating warehousemen to the price of eggs and other commodities.

First: There is no cold storage trust or combination of any kind.

Second: The public cold storage warehousemen do not own the goods stored.

Third: These products are owned by a large number of competing dealers all over the country.

Fourth: Market reports show a big decrease in the receipt of eggs in all the leading cities and an increase in the trade demand and output.

Fifth: On November 1, 1913, there was a shortage of 664,016 cases of eggs (thirty dozen each) in forty-five of the leading public cold storage warehouses in the country.

Sixth: During October this year there was a reduction of 635,792 cases of eggs in the holdings of these forty-five houses representing eggs going into consumption.

Seventh: These eggs are now being withdrawn in large quantities, regardless of boycotts and newspaper agitation, to meet the demand.

Eighth: The stocks remaining in the warehouses are insufficient to meet the prospective demands of the market on the basis of last year's output until the new crop arrives next March.

The subject that I am asked to present to you today is a topic very greatly misunderstood and concerning which many erroneous impressions have been formed in the popular mind, largely because of the position taken by a part of the press in the discussion of the high cost of living. It is unfortunate that sensational and unreasonable allegations and attacks are freely published in an agitation of this kind, while sober facts and true statements offered in contravention are generally neither desired nor welcomed.

During the year 1910, in spite of the fact that the range of prices of nearly all articles entering into human consumption had been advanc- 
ing, there began an agitation blaming cold storage for high prices. It was asserted that cold storage facilities were used to artificially control markets and increase prices; that foods were carried for long periods of time and that the process was detrimental to the public health. Thereupon there were held a series of investigations and hearings to determine the facts, such as the Massachusetts Commission to Investigate the Subject of the Cold Storage of Food, the Hearings before the Committee on Manufactures of the United States Senate, the investigations of the Food Research Laboratory, U. S. Department of Agriculture, the study of Cold Storage Business Features and Prices by the Bureau of Statistics, U. S. Department of Agriculture and the report of the Chicago Chamber of Commerce on the subject. Without exception, all these investigations pronounced in favor of cold storage as a valuable modern public utility in performing the function of conserving our perishable foods, preventing deterioration and waste and affording a highly developed method by which the great surplus products of the flush season could be wholesomely preserved for consumption out of season, during nature's scant period of production.

For a time the attitude of the press was much more favorable and the laws pássed by quite a number of states were fair and reasonable in regulating the business, with the exception of the law passed in Pennsylvania, which is extremely drastic, and the New York law, which is burdensome in some of its features.

At the time of the meeting of the Third International Congress of Refrigeration in this country at Chicago, as recently as last September, the newspapers and magazines, quite generally, paid tribute to the science of refrigeration in all its modern applications. But how fickle is public opinion as reflected in the daily press, and how quickly the passing currents of discussion sweep us from our bearings and conclusions.

Now that Mrs. Hen has curtailed her activity and Mr. Man has increased his demand for her product, these economists of a day settle it all in a single editorial, the politicians attempt to solve the problem in his legislative panacea, and the cold-storage man is the "goat" of the situation.

The cold storage industry is between the "upper and nether millstone" in the politics of the agitation. The Republicans said it was cold storage and not the high tariff that did it, and now the Democrats claim it is cold storage in spite of the low tariff that makes our living high.

Let us now consider the facts in the case as established by market statistics, government investigation and the testimony of experts, and attempt to correct popular misconceptions by getting at the demonstrated truth of the matter.

The extent of the facilities for the conservation of foods by refrigeration is indicated by the following figures from the Ice and Refrigeration Blue Book: In 1911 there were 860 public cold storage warehouses having 
about $169,541,000$ cubic feet of storage space and representing an investment of about $\$ 75,000,000$. It is estimated that the value of goods stored in one year ranges from $\$ 500,000,000$ to $\$ 700,000,000$. It is, however, calculated that not over from five per cent to ten per cent of the annual production of such foods as eggs, butter, poultry and meats are placed in cold storage for periods of over thirty days. This corrects the popular notion as to the quantity of products held in cold storage, but another error is in reference to the length of the period of storage. The U. S. Department of Agriculture, Bureau of Statistics, made an exhaustive study of this subject, based upon reports from the warehouses of the country for the years 1909-1910. In stating the proportion of foods remaining in storage for ten months, the report (Bulletin No. 93, page 30) says: "Let the percentages for the deliveries of ten months be stated. These are represented by 99.9 per cent for fresh pork, 98.9 per cent for dressed poultry, 97.8 per cent for butter and 99.9 per cent for eggs. The important observation to be made is that the receipts into cold storage are entirely or very nearly exhausted by the deliveries within ten months." The same report gives the average length of storage as follows: Fresh beef, 2.28 months; fresh mutton, 4.45 months; butter, 4.43 months; poultry, 2.42 months; eggs, 5.91 months. This is the answer to the exaggerated stories of the long holding of these products.

We come now to a consideration of the effect of cold storage on prices, especially of eggs, which is the essence of the present controversy. Let me introduce here in chart form a statistical review of the New York egg market from March, 1912, to November, 1913, together with a summary and comparison of the figures. This review was prepared by Mr. F. G. Urner of the New York Produce Review. (See next page.) 
Statistical Review of New York Egg Market, March, 1912, to October, 1913, Showing Receipts, Movement to and from Storage and Range of Prices.

\begin{tabular}{|c|c|c|c|c|c|c|}
\hline \multirow{2}{*}{ Month. } & \multirow{2}{*}{$\begin{array}{l}\text { Receipts, } \\
\text { Cases, }\end{array}$} & \multirow{2}{*}{$\begin{array}{l}\text { Stock in } \\
\text { Storage, } \\
\text { First of } \\
\text { Each } \\
\text { Month. }\end{array}$} & \multirow{2}{*}{$\begin{array}{l}\text { Net Input to } \\
\text { Storage ( } \\
\text { and } \\
\text { Output ( }\end{array}$} & \multirow{2}{*}{$\begin{array}{c}\text { Calculated } \\
\text { Total } \\
\text { Output } \\
\text { from } \\
\text { Wholesale } \\
\text { Market. }\end{array}$} & \multicolumn{2}{|c|}{$\begin{array}{l}\text { Range of Prices for } \\
\text { the Better Grades. }\end{array}$} \\
\hline & & & & & $\begin{array}{c}\text { Fresh } \\
\text { Western. }\end{array}$ & Refrigerator. \\
\hline 1912 & & & & & & \\
\hline March & 459,859 & None & Negligible & 450,000 & $21 @ 27$ & None \\
\hline April. & 742,893 & Negligible & $+307,000$ & 416,000 & $19 @ 22 \frac{1}{2}$ & \\
\hline May. . & 923,261 & 307,000 & $+599,000$ & 349,000 & $17 \frac{1}{2} @ 22$ & \\
\hline & 561,402 & 906,000 & $+177,000$ & 384,000 & $18 @ 21$ & \\
\hline July & 435,16 & $1,083,000$ & $+71,000$ & 364,000 & $18 \frac{1}{2} @ 22$ & \\
\hline Aug & & 1,1 & $-20,000$ & 387,000 & $18 \frac{1}{2} @ 24$ & $22 \frac{1}{2} @ 23 \frac{1}{2}$ \\
\hline nber. & & 1,13 & $-48,000$ & 357,000 & $22 @ 30$ & $22 \frac{1}{2} @ 24 \frac{1}{2}$ \\
\hline October & 256,69 & $1,086,00$ & $-171,500$ & 428,000 & $24 \frac{1}{2} @ 34$ & $22 \frac{1}{2} @ 24 \frac{1}{2}$ \\
\hline Noven & & 91 & -25 & 421,000 & $26 @ 38$ & 21 @, 24 \\
\hline $\begin{array}{c}\text { December.... } \\
1913\end{array}$ & 157,406 & 662,000 & $-312,000$ & 469,000 & $25 @ 38$ & $18 @ 23$ \\
\hline January.... . . & 194,642 & 350,000 & $-218,000$ & 423,000 & $23 @ 30$ & $18 \frac{1}{2} @ 21$ \\
\hline Febrt & 257, & 132,000 & $-117,000$ & 383,000 & $19 \frac{1}{2} @ 26 \frac{1}{2}$ & $15 \frac{1}{2} @ 21$ \\
\hline Mar & 447,25 & & $-15,000$ & 440,000 & $18 @ 23$ & $15 @ 17 \frac{1}{2}$ \\
\hline & 6 & Negligit & $+225,500$ & $454, \mathrm{C}$ & $18 \frac{1}{2} @ 21$ & $\ldots \ldots$ \\
\hline May & 742,862 & 225,500 & $+367,500$ & 365,000 & $18 @ 22$ & \\
\hline & & 593,0 & $+225,000$ & 347,000 & $18 @ 22$ & \\
\hline & 5,36 & 818,0 & $+54,000$ & 401,000 & $18 @ 23 \frac{1}{2}$ & $23 @ 24 \frac{1}{2}$ \\
\hline & & & $-53,000$ & 396,000 & $20 @ 27$ & $23 \frac{1}{2} @ 26$ \\
\hline & & & $-133,000$ & 450,000 & $24 @ 32$. & $24 @ 27$ \\
\hline October.......... & 288,851 & & $-148,500$ & 437,000 & $27 @ 35$ & $25 @ 28 \frac{1}{2}$ \\
\hline November 1 to 15 . & 107,078 & 537,500 & $-109,500$ & 217,000 & $31 @ 44$ & $27 \frac{1}{2} @ 30$ \\
\hline
\end{tabular}

SUMmary.

Cases.

Receipts, March 1 to October $31,1912 \ldots \ldots \ldots \ldots \ldots \ldots \ldots \ldots \ldots \ldots$ 4,056,159

Receipts, March 1 to October 31, 1913.................. 3,859,911

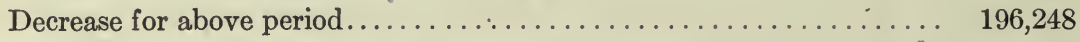

Average monthly trade output, March to October, $1912 \ldots \ldots \ldots \ldots \ldots \ldots$. 391,850

Average monthly trade output, March to October, $1913 \ldots \ldots \ldots \ldots \ldots \ldots \ldots \quad 411,250$

Deficiency in greatest storage accumulations, August 1, 1913, compared

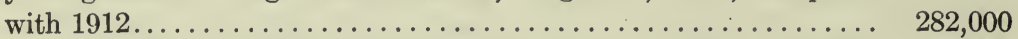

Deficiency in storage accumulations, November 1, 1913, compared with $1912 \quad 377,000$

As bearing upon the reasonableness of present holding prices for storage eggs particular consideration should be given to the following:

Prospective needs, November 1 to January 31, based upon average

Cases.

output since March $1 . \ldots \ldots \ldots \ldots \ldots \ldots \ldots \ldots \ldots \ldots$

$1,233,750$

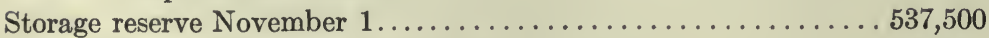

Receipts November 1, 1912, to January $31,1913 \ldots \ldots \ldots \ldots \ldots \ldots 11,000$

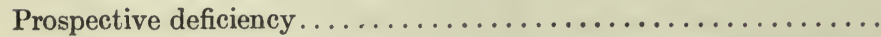


This table demonstrates the entire theory of cold storage and ity economic aspects. It shows the heavy receipts in the market during the spring months, for example, 923,261 cases in May, 1912, and 742,862 cases in May, 1913. Likewise it shows the light receipts in the market during the fall and winter months, for example, 157,406 cases in December, 1912. At the same time it exhibits how the surplus receipts of the spring enter storage; for example, the storage input of 599,000 cases in May, 1912, and 367,500 cases in May, 1913. The fact that the movement into and out of cold storage is regular, seasonable and in exact reference to the receipts in the market, is clearly shown, indicating an obedience to the law of supply and demand and disproving any assumption of control or corner. A study of the prices shows the heavy losses of a year ago and the natural profits of this year because of the shortage.

The summary and comparison is illuminative, disclosing a decrease in receipts in the market of 196,248 cases, an increase in the trade output of 155,000 cases and a deficiency of 377,000 cases in the storage holdings on November 1st, compared with last year. It should be remembered that the reserve stocks have to serve the market until next spring, and that under the same receipts as last year, we face a prospective shortage of 185,250 cases to carry us through, unless by reason of price or decreased demand the average is changed. New York is an absolutely open market and is typical of the whole country. The New York Produce Review says, in commenting on these figures, "The unfortunate difficulty is that the facts of the case are so plain and so simple that they can hardly be believed by agitators and others who are saturated with the conviction of monopoly, combinations, price control or other underhanded and mysterious manipulations."

The Massachusetts Commission on Cold Storage has this to say on the effect of cold storage on prices and increased production:

"The per capita receipts of the chief food products subject to cold storage handling, namely, eggs, butter and poultry, increased greatly in Boston and New York markets during the decade 1901-10 as compared with the decade 1881-90, prior to the general adoption of cold storage methods. This fact appears to indicate that cold storage has contributed to increase the volume of production. . . . The average prices of butter and poultry were lower in the second decade than in the first, the average price of eggs was slightly higher, but this fact is explained by peculiar conditions affecting the egg market."

Mr. F. G. Urner in testifying before the U. S. Senate Committee on Manufactures stated: "The per capita consumption of eggs at New York has increased largely since ample cold storage facilities became available." Again he says: "The average price of fresh gathered and storage eggs taken together were lower during the season of scarcity since cold storage has been available than were the prices for fresh gathered eggs before cold storage was available, notwithstanding a well-known 
advance in the prices of nearly all commodities." (Chart exhibited containing comparisons and conclusions as above from Mr. Urner's figures.)

Mr. George K. Holmes, Chief of Division of Production and Distribution, Bureau of Statistics, U. S. Department of Agriculture, thus concludes Bulletin No. 93, issued April 5, 1913, on Cold Storage Business Features: "The reader must be aware that this investigation has negatived some popular misconceptions with regard to the cold storage business and has substantially sustained some of the assertions made by cold storage warehousemen." The same authority in Bulletin No. 101, issued April 5, 1913, says: "The cold storage situation, as it has presented itself to some writers, has been assumed to be one in which the cold storage interests have combined to raise the price of commodities. Evidence would need to be presented to sustain this contention and to indicate the feasibility of the combination of an immense number of wholesale dealers in all parts of the country for the purpose of regulating prices through the use of cold storage warehouses. Perhaps it is not generally known that the owners of the cold storage warehouses do not store commodities for themselves, but, on the contrary, let cubic space in their warehouses to customers, who place therein such perishable and other commodities as they please." Again this report states: "It is by no means to be admitted that the cold storage business is responsible if the prices of its commodities have increased or if the price levels of its commodities have increased. Let the fact be what it will with regard to the effect of cold storage on prices, the fact remains that cold storage has been of incalculable benefit to consumers in providing commodities for consumption out of the natural productive season." (Charts exhibited from Bureau of Statistics.)

As to the new inquiry now suggested by the Attorney General regarding conspiracy in restraint of trade, or of the House of Representatives as to the economic effects of cold storage, we are willing to submit our facts, knowing these departments of the government will come to the same conclusion as the Department of Agriculture, if the investigation be honest and thorough.

With respect to the alleged injurious effect of cold storage on health, there is an abundance of scientific testimony to the contrary. This phase of the subject has not been attacked in the present agitation as it was several years ago. The Massachusetts Commission declared itself on this side of the question as follows: "Instead of being a menace to the public health, cold storage has, in the main, exhibited itself as a great agency for the conservation of the vital resources of the population. It has enlarged, diversified and enriched the food supply of the people. Without cold storage the crowded masses in the urban centers would be obliged to subsist on a dietary at once more meagre and more costly than that enjoyed at the present time." 
Dr. M. E. Pennington, Chief of Food Research Laboratory, U. S. Department of Agriculture, testified before the U. S. Senate Committee in reference to poultry as follows: "There would probably be a greater change in twenty-four hours if the temperature was from $65^{\circ}$ to $75^{\circ}$ Fahrenheit, than if the temperature was $10^{\circ}$ Fahrenheit for twelve months." Dr. Pennington also makes this statement in one of the government bulletins: "It is a comparatively simple matter to keep birds in good condition from one season of production to the next, in a well-constructed cold storage warehouse, provided those birds are received at the warehouse properly dressed, chilled and packed, and with such promptness that decomposition has not obtained even a slight foothold."

In conclusion, it may be pertinent to the topic to briefly consider cold storage legislated, adopted and proposed. Eleven states have passed laws regulating the cold storage business, and while many of the provisions of these laws are unnecessary and non-effective, for the most part they are reasonable and workable. As the time limit is apt to be the most oppressive and restrictive form of regulation, it is of interest to note the provisions in this respect in the different acts. Twelve months limit, with privilege of extension, is provided in the laws of California, Iowa, Louisiana, Massachusetts, Nebraska and North Dakota. Ten months, with power of extension, is the rule in Jersey. Ten and twelve months, without extension, is the law in New York. Nine months storage is permitted in Indiana. Delaware requires a limit of six months, which may be extended to eight months, and Pennsylvania has a law which is the most drastic as to time limits yet adopted. It provides that no foods can be offered for sale which have been stored beyond the time mentioned, which runs from four months on beef to ten months on undrawn dressed fowl and there is no provision for extension. It is past finding out how such periods were selected, when twelve months is the only logical and natural limit if one is to be imposed, so that products can be carried from season to season, and then providing for extension of time, if proper and necessary. The next step should look to uniformity in this type of legislation, and it is a good sign that the Association of State and National Food and Dairy Departments has prepared a model, uniform bill, which, while not all that could be desired, is a step in the right direction and a number of states have adopted this bill. It is reported that the Commissioners of Uniform State Laws are also working on a measure which promises to be reasonable and fair.

After this discussion, it is needless to say that the bill proposed in Congress by Representative McKellar, providing for a time limit of ninety days, is perfectly absurd and impossible. It would destroy the entire cold storage industry and take from the people this modern and efficient agency of food conservation and distribution.

Mrs. Smrth: We would like to have some discussion on this subject of cold storage. 
Delegate: Is there not some danger in a time limit of twelve months?

Mr. Horne: The producer storing these products will take them out when he has the call for them. He will not take them out when he is to compete with the fresh product. That is not done at all.

Delegate: For example, if the time limit was twelve months, wouldn't he be compelled to do that?

Mr. Horne: As a matter of fact he is not asked to do that. It is unnecessary.

Delegate: I think the time limit in the law construed to mean that anything is unfit for food after it has passed the time limit, is vicious and unreasonable in every particular, and should be repealed.

Delegate: Don't it make any difference what time the goods are put in? Are not goods put in in May better at the end of nine months than when put in at the end of July or August?

Mr. Horne: An April egg I should say ten or eleven months in storage, would be better than an egg stored in July or August. I should say that eggs shouldn't be kept so long.

Delegate: Why wouldn't a ninety-day bill reduce the cost of these prices? I would like to know why it wouldn't.

Mr. Horne: The product would be in excess at a time when there was not the demand for them. The farmers would go out of that line of business. There would be a dearth when wanted, and an increase in prices for a long time. It would be perfectly illegal, and as a matter of fact wouldn't be feasible, couldn't be done.

Delegate: Do you mean the farmers would stop raising the product? Mr. Horne: Yes.

Delegate: You spoke of seasonal storage. If you put in April eggs, the prices are the same to remain there to January? But if you take out the April eggs and put in others in August you got two seasons' storage to pay.

Mr. Horne: Eggs stored in August would command a monthly rate.

Delegate: When does that rate cease or begin?

Mr. Horne: That is purely a matter of private contract between the cold-storage man and the dealer. A large amount of storage is done in the spring. Summer storage is another matter.

Mr. Brown: In regard to the statistics about material being marketed, substantially all of it within ten months, what was the starting month?

Mr. Horne: Those figures begin with the egg year in the case of eggs. These figures were reported by the Department of Agriculture. That is, I assume, where we got those figures. 
Mr. Brown: Wouldn't it make a difference what month it began with?

Mr. Honne: Certainly it would. It would have to begin when it went in.

Mr. Brown: I notice you mentioned one thing which I think was important, that the storage man was an ill-used man, that he doesn't buy the stuff himself from storage. I think that is the story. Another point which should be brought forth, something in which every city is interested in, Do packing houses use their house for the storage of other products than meats?

Mr. Horne: Yes.

Delegate: Will you discuss the preservative efficiency of cold storage? There has been a popular impression, for instance, that a coldstorage egg was a bad egg. Will you tell us something about the preservative efficiency of cold storage?

Mr. Honne: May I answer your question by asking this of an expert on this topic? I would ask that Dr. Pennington answer this gentleman's question.

Dr. Pennington: I really think I occupied enough of your time previously.

Mr. Horne: No, we would like to hear from you because you are an expert.

Dr. Pennington: The department in the keeping of eggs and poultry under refrigeration, both in the cooler temperature which is ordinarily about $32^{\circ}$, and freezing, which is $10^{\circ}$ below zero, we find that chickens will keep for at least one year, absolutely wholesome and in a desirable condition and salable condition. At the end of nine months of storage, if the fresh well-handled product is cooked side by side with storage well handled, the most expert chicken tasters we have, have been unable to tell the difference. At the end of twelve months, these expert chicken tasters, by considering it carefully, can mostly tell the difference. Sometimes they can't. After twelve months or sixteen months we can always tell them by taste. When it comes to a laboratory analysis, the scientific side of the question, there is a difference in the chemical composition, so small, however, it can be found in the laboratory but not large enough to make any difference so far as we are able to detect any difference in food value or wholesomeness of the product. At the end of six months or a year we have never been able to detect from our bacterial and chemical analysis, anything that is of absolute importance or anything that it is necessary to consider, up to the storage period of one year. Therefore we say, and we think we have abundant evidence to justify 
our so saying, that poultry will keep in perfect condition for a period of one year or from season to season. Eggs, if in good condition, will certainly keep for a period of nine months, and many will hold up to ten months. For our own consumption I put them in in April and use them well into January.

Mr. Horne: Can you tell us what in your judgment would be the effect of any limit of time under, we will say, ten months on eggs, or twelve months on butter. What would be the effect on the consumer if such a law was in effect?

Dr. Pennington: So far as we can judge as to the situation, the production, supply and distribution and demand are some of the various factors entering into this question. To limit the time of the storage period beyond a certain period is decidedly against the consumer in serving his demands.

Delegate: At what temperature are eggs and some of the other leading commodities kept?

Mr. Horne: Eggs are carried at from 29 to $31^{\circ} \mathrm{F}$. and apples are carried at from 30 to $32^{\circ} \mathrm{F}$.

Delegate: Then all things could be kept in one room?

Mr. Horne: By no means.

Delegate: Different temperature for different things?

Mr. HoRne: Yes.

Delegate: Would you say the high cost is due to refrigeration?

Mr. Horne: Lack of refrigeration.

Mrs. Sмiтh: The question has been asked as to what Dr. Pennington thinks as to a nine months' limit on cold storage. Is fish fit to eat after being in storage nine months?

Dr. Pennington: I know of no reason why, if fish was good when it was put in, but that it should be fit to eat. I wouldn't say as to much beyond that time, but I know that at the end of a year it is good to eat.

Mrs. Sмiтh: Will Dr. Pennington tell us how she supplies her family, in the way of pure food?

Dr. Pennington: My family lives entirely on food from out of cold storage. I told this tale at Atlantic City last night, and I have told it so many times, everybody must know it now. We buy in large enough quantities to last the family a long period of time, being desirable both from the standpoint of cold storage and also convenience. For instance, our eggs go in in April and we use them into January. In between that time our cold storage product is exhausted and a fresh supply is available, and we have pretty good ways of getting fresh products. We also use canned eggs. In other words, we start out in the spring when eggs are good, put them in a two-pound can, and do them up just as the packers 
are doing them in a wholesale way. The supplies of course are fresh. When the butter supply is best, we buy it. About 300 pounds it takes for our family for a year, in three-pound tin cans. The butter this year came in from Minnesota. We have a year's supply. We buy every three or four months. The housekeeper in our family is a woman who looks after that part. I am not a housekeeper. She goes to the wholesale meat butcher, she knows how to handle beef, having studied the question carefully, and she buys the meat in wholesale quantities,-carcasses of mutton, sides and loins or ribs or whatever we want, in regular wholesale prices. Then it is cut into household quantities-steaks, chops, meats for stewing, soup bones, suet and all the rest of it. These cuts are made up in small quantities as our household demands them. They are put into the freezer, sealed, each package being packed and numbered and our household ledger -instead of attending to these things over the telephone we run our house by means of our household ledger-will show for instance "No. 7," which means so many chops, "No. 5," which means a certain weight of roast, and so on. We buy apples by the barrel, put them in coolers. We buy cranberries, 32-quart cases, hold them for a year if we want to. We also put in baskets of corn. We are having corn off the cob just as fresh as you have it from the stalk. We are getting the benefit of wholesale prices and we are getting better food than we ever did in our lives, because we are going back to the very first source of production of handling. We put in the best food we can get. We are running the household account on an economical and efficient basis. We are getting our money's worth out of it, and it has made housekeeping a very fascinating experiment indeed, and a business proposition. Whereas, from the ordinary telephone point-ofview, whether it is 2 cents' worth of something you want, it takes 5 cents to supply it and you don't get what you order at that. Our way is much better.

Mrs. Smith: I asked Dr. Pennington if I could do this and she said "No, I couldn't." But, for instance, if a number of women clubbed together to learn what our households wanted-I am not at all scientific myself-we could put into storage our particular packages, and follow out the storage system as she has outlined. In that way we could have a supply that would reduce the high cost of living to a minimum.

Delegate: Has she different departments for different things at different temperatures, or are they all at the same temperature?

Dr. Pennington: Yes. You can divide into the necessary temperatures. You can hold all your vegetables and your food-stuffs that don't have to be frozen, ordinarily at 32 , and what is ordinarily to be frozen is held at 10 . So the arrangement of temperatures is not so great for ordinary purposes. The larger the unit the greater the efficiency.

Delegate: Refrigeration, especially for a private home, is rather expensive, isn't it? 
Dr. Pennington: We are using public refrigeration houses.

Delegate: Isn't it one of the difficulties of cold storage taking care of the stuff after it leaves there? It seems to me it wouldn't keep very long after it comes out of cold storage.

Dr. Pennington: I might say that in modern cold storage plants they are never out of the proper temperature.

Mr. Horne: In Atlantic City yesterday, in discussing the question of apples, it was stated that apples after being taken out of cold storage kept better than apples kept in common storage, and after being taken out of storage they showed up better than apples kept in common storage for a like period.

Delegate: How about peaches?

Mr. HonNe: Peaches in cold storage are not kept for a long time, generally or usually only for several weeks or a month.

Delegate: I notice the skin usually falls off.

Mr. Horne: I have been in the business for quite a number of years, and peaches never kept over a month or six weeks; that is the limit.

Mrs. Sмiтн: Is it the consensus of opinion among cold-storage people interested in cold storage, that there should be a cold storage law?

Mr. HonNe: There is a law which provides for selling cold storage goods for what they are. They passed a measure restricting the time limits.

Mr. Brown: How would you remove the prejudice from the consumer's mind that the price is established through cold storage houses?

Mr. HonNe: That is quite a problem. I think our friends are reasonable men whom we have had listening to us, and who will study the subject honestly and deliberately. I am sure when we get a fair chance at them, and I believe I am stating a fact, that the reporters who are here representing the newspapers are not responsible for what is contained in the newspapers, but the city editor's fault who is looking for sensation, for something that is unusual. The usual, regular, wholesome news is not the stuff they want to print, or put in their headlines.

Delegate: You are right on that.

Delegate: How do you provide for your marketing?

Dr. Pennington: We market twice a week, make our menus ten days ahead. We take out a basket load of meats each week. Of course, butter and eggs, peaches and fruits, are easier to handle. It is your fish and poultry you must start on time. The basket comes out Thursday because we have fish Friday, and fish is the first thing you must use Friday night, thawed out and ready to eat. Always leave it thaw out where it is cool and dry. Fish, Friday night, Saturday night, chops, and on Sunday, roast. In the summer time you place your meat in the refrigerator so it ripens 
gradually in your ice box, and by Sunday your roast is ready to eat. Mutton ripens first. If you have roast chicken it takes considerably longer to ripen. They are picked well, then put in the ice box where they are cooled. I know it takes three or four days for a roaster to ripen properly; it takes about three days for a broiler to ripen. It takes, of course, from 24 to 48 hours for a chicken to thaw. It comes to the house frozen. These are some of the problems of supplying your own home and family. Besides, a man is needed to help out in the work generally. This is how your menu is made up and carried out from the time it leaves cold storage until it is served in the form of a meal on your table. The basket goes out 14 miles by railroad, and then returned and delivered to the house from the station by the ordinary carriages.

Delegate: Can you soft boil an egg after it has been in storage a year?

Dr. Pennington: Yes, you can boil it, but whether you can eat it or not I don't know. I never tried it and I don't think I would.

Delegate: Yes, certainly it can be done. I tried it after 14 months. We just tried it for an experiment, after 14 months. I represented the storage house and the egg dealer.

Mr. McDonald: I move that we offer a vote of thanks to Dr. Pennington, Professor King, and Mr. Miller and Mr. Horne for their able addresses here this afternoon.

[Motion seconded and carried by unanimous rising vote.]

[Adjournment until the evening session.] 


\section{Council Chamber, City Hall, Friday Evening, 8 o'Clock.}

Chairman, Charles Z. Tryon, Esquire, President, Hardware Merchants' and Manufacturers' Association.

Mr. Tryon in opening the meeting spoke as follows: $M r$. Calwell, Ladies and Gentlemen: I take it that the problem of all civilization is to devise ways and means whereby men may live together in communities with a just proportion of comfort, convenience and happiness to all. The savage was never hampered with any such conditions. He killed his enemies without legal complications, he found his own food in the forest without the necessity of the railway or the store, he grew his own corn and he carried his skins to the nearest trading post and swapped them for such articles as he needed in the way of powder, shot and simple clothing without recourse to any medium of exchange.

Now all the varied complications of the civilized life of today-the great storehouses, great banking institutions, our railways and granaries, are simply complications that have arisen because we are now endeavoring to live in greatly congested communities. We are all trying to solve, under very difficult conditions, the problem of civilized life, that is, to live together in some measure of harmony, comfort, justice and happiness to all.

Men have discovered and invented many things. They have experimented with the great forces of nature with wonderful results. Some things have been tried so many times that we may feel positively sure of definite results. Others are still uncertain, but I ask you to remember that there is at least one thing about which we may be absolutely sure, and that is the unchangeable and positive law of nature. There is nothing quite so positive and sure as agriculture.

Engineers may build wonderful structures, and up to a certain point the accumulated wisdom of centuries tells them that a structure will stand a certain amount of weight or pressure; beyond that point these engineers are uncertain. A man may build a twenty story building, but he is not sure that he can rent the rooms. A railroad can project its lines into a new country, but many of them have failed before that country could sustain the railroad. But when we come to mother nature in her primitive form, we are at once upon a sound foundation with absolutely no uncertainty. You may lose faith in mechanics, in science, in philosophy, and even in religion, but there is one solid rock upon which you can always stand no matter who you are or where you are, and that rock is natural law. Under certain given conditions, nature will always do the same thing.

When you take a seed that is living and put it into the ground, give it proper natural surroundings and conditions, it will grow and you cannot 
stop it unless you root it out and kill it. We know the sun will rise tomorrow. We know that next spring crops will grow. It is upon this basis which every man actually lives, whether he recognizes the fact or not.

If, therefore, agriculture may be considered the basis of all life, and we find ourselves in congested communities, detached of necessity from close contact and association with this foundation of life, it is at once evident that the greatest problem of modern days is to get the proper adjustment between the producer and the consumer, but in making this statement, dividing the producer from the consumer, we make a statement which is not exactly true, because as a matter of fact all are producers and consumers.

This convention is for the purpose of determining whether or not the present arrangements between the producers and consumers is the best that can be thought out, but whatever our deliberations may lead to, we must recognize the fact that the present methods are the result of slow progressive changes, society adjusting itself at each point as new conditions have arisen, and no radical and completely successful rearrangement can possibly be adopted in any short space of time. Let me diverge for one moment. I happen to be personally one of those terrible middlemen that we now hear so much about, who stands between the producer and the consumer. I happen to be a jobber, but I represent tonight the Hardware Merchants' and Manufacturers' Association of Philadelphia, composed of the great manufacturing industries of Philadelphia and the great hardware distributing houses.

It is not my purpose to go into a discussion of the question of jobbers. You probably have discussed that at many of your meetings. I believe the jobber is a necessity, otherwise he would not exist, and so I believe the middleman and the distributor of agriculture is a necessity.

Now what do we do in the hardware business in the effort to adjust ourselves to the complicated conditions of trade? We have formed this association of manufacturers and jobbers, and we get together once a month in friendly intercourse, and there we thrash out in a spirit of good fellowship our differences. This I claim is the difference between modern trade and that of a few decades ago. People who have interests that are divergent or partially in harmony and partially divergent, instead of standing off at long range and fighting out the battle by correspondence, meet face to face and talk the situation over.

In a larger sense that is just what world's fairs are for, so that people from the rural districts can see how shoes are made, how clothes are made, what thought has been required in designing them; and the man from the city sees the great agricultural products there exhibited. So this convention is for the same purpose of bringing together the man that produces the great natural wealth of the country and the man that produces other things, so that each shall have an intelligent appreciation of the other's viewpoint of life. 
I understand that this evening is to be very largely devoted to an illustrated lecture upon the education of our boys and girls in relation to the fundamentals of life. How simple, and yet how vastly important; as a matter of fact it is just exactly what every parent is trying to do. I can look back upon no experience in my life which I consider of more value than three summers which I spent as a boy upon a farm, harrowing corn, working in the truck garden, picking potatoes, making hay, thrashing, milking and a hundred and one things incidental to that life. I learned then, as I should never have learned since, the language of every barnyard fowl and the practice and customs of the men who form in reality the backbone of our nation-The American Farmer. [Applause.] Now this advantage is rarely given to the city youth; just as the problems of city life are rarely exhibited to the agriculturist. Consequently the proper adjustment has been long delayed, but such meetings as these will rapidly clear the ground for an intelligent understanding of the whole situation by all parties.

What is the condition in Pennsylvania today regarding these men upon whom every one of us in the city depends? What has the farmer done that his children may know how, intelligently, to get the very best of mother nature,- - she is bursting with good things, if they but know how to gather nothing less than the best.

We have agricultural colleges which are doing a magnificent work, and many of our young men are attending these institutions, but what we need are agricultural schools that will charge a nominal price for the proper education of the youth of our farming districts. There is perhaps too much head and tail to our system of agricultural education today and not enough body. This is the trouble with too many of the projects today which are launched at the hands of our legislatures. I repeat, it is this secondary education that is desired in this state, and what we want is men who can get back into the country and teach the people what is the best modern method to pursue in the raising of their crops. That I take it is a part of what is hoped to be accomplished by these conventions, together with the equally important matters of agricultural banking; relations to the railroad, middlemen, warehouse companies, etc.

In closing may I say that the boys' camps which are now being instituted in our mountain districts, where young men and boys are sent in the summer time rather than to our fashionable hotels, are a splendid course in the line of healthful education, but if I had the opportunity to choose between sending a son of mine to one of these camps or of sending him for the summer months to a farm, offering him the opportunity of getting into the closest possible touch with nature, I would decide to send him to that farm instead of to the boys' camp. [Applause.]

Mrs. Sмrтh: We have with us tonight Mr. A. P. Sandles, President of Ohio Agricultural Commission, who is responsible for the work along 
secondary educational lines in Ohio. Mr. Sandles can be of the greatest benefit to us and to this State in saying a few words to us on the work he has been doing out there. Almost all the states are doing better work along this line than Pennsylvania. This Ohio trip shows us what they are doing in Ohio in that direction. I am only too sorry that I am obliged to limit him in his remarks to about eight minutes.

\section{Mr. A. P. Sandles (President, Ohio Agricultural Commission):} How many in this place tonight have at some time in their lives lived on a farm? [Hands raised.] How many now live on farms? [Hands raised.] I imagine that the conference you now have in progress is a good business to be in. I am sure that suggestions will be made here that will enlarge your view and your vision, and your power to do good where good must be done, if the wealth and strength of this nation are to continue and to be perpetuated. We come to your city today one thousand and five, boys and girls, who have accomplishment to their credit. Ohio is getting what it has long needed, and what other states need, and that is, enthusiasm right back in the cornfield and in the kitchen. [Applause.] We have 150 girls who have won prizes at baking, sewing and canning; girls who are emulating the housekeeping virtues of their mothers in the kitchen, and that kind of virtue means more than the Tango and Turkey-Trot athletics of modern days. [Applause.] The girl who can cook a meal and bake bread is making fewer divorce cases for the future courts.

We have with us boys who are working out their own problems, boys who in their eagerness to win are consulting the Director of the Experimental Station of Ohio, who is here tonight, Director Thorne. The boys who are getting licked in this contest are good soldiers. They say, "We will fight again," but before we do it we are going down to the College of Agriculture at Columbus, and we are going to get some scientific knowledge, and we will get the measure of that other son-of-a-gun who beat us last year. [Applause.]

We have here tonight Dean Price, who if he had time could stand up here and testify how the College of Agriculture attendance is multiplying every year, and we are doing something for the boy uniformed in overalls right back in the cornfield. Yesterday when we were in the White House, being royally received there, it was the Log House shaking hands with the White House.

We are giving to the boys of Ohio the conviction that they can win victories, can see something of the world, and win some of its honors and distinctions on the farm, as well as the boy and girl who lives off the farm. We are giving to the boys and girls in Ohio the opportunity to get their names and their pictures in the newspapers of the state of Ohio. Don't you know I would rather publish the name and picture of the boy who can raise 100 bushels of corn to the acre, or the girl who can win a domestic science contest-I would rather publish that kind of a picture on the first 
page of a newspaper than I would Jack Johnson or Harry Thaw. [Applause.]

My good friends, we have got the corn and dirt religion in Ohio working in every county, every township and every nook and corner, every school, every church, the Y. M. C. A., the Grange, the Chamber of Commerce, and the bankers and the railroad men are trying to get into good society in Ohio. [Applause.]

My good friends, we have an example never before equaled in the world, of $\$ 40,000$ being contributed in good money of volunteer subscriptions to pay the expenses of boys and girls to the national capital, and to the good old city of Brotherly Love. It is the public spirit in Ohio that is paying the bill, and not the public treasury. It has taken hold everywhere. We are learning out there that our government has been stimulating manufacturers, as well as many other lines, that at last, when the high-cost of living is a menace to the welfare and happiness of this country, our nation and people are turning the corner-stone and bed-rocked wealth and prosperity, and that is, agriculture.

My good friends, I wish I had a little more time, but I am going to cut it short, to tell you what a wonderful hold it has had, how much inspiration it has given to the boys and girls.

Don't you know that a lot of farmers are so stingy and narrow-gauged that they make little money-mills out of the boys, trying to extract every penny from their labor. They let them eat and sleep in the house, but make them work like horses, and they don't want the boy to get any more pleasure out of life than the horse is getting. That is just what is taking a lot of boys and girls off the farm, and it is this contest work, this encouraging the boy in the field that is making him fall in love with the dirt religion in Ohio.

My good friends, I want to place on exhibition here tonight three of our products, two of ours and one of Pennsylvania. Mr. Bright, I want you to stand up. Here is a manly young man, who went to work and put his head in the game, and by studying drainage and fertilization, and good seed-bed, won the championship prize as a wheat-grower in Ohio-54 bushels, 37 pounds, and that is a splendid victory not only for Earl Bright, but for humanity. This little gold badge was given to him by the boys and girls of his township because he won the honor for his community. Earl is a good fellow, and I have given him a certificate to pick out any young lady he wants in the who'e community.

Mr. Rose, stand up. This manly young fellow, unmarried [laughter], raised $131 \frac{7}{10}$ bushels on one acre. [Applause.] That is splendid. And when a boy puts a grain of corn in the ground and gets two ears, and contributes that to the wealth of the world, that boy is contributing more to the cause of humanity than Jack Johnson, the prize fighter, ever did. [Applause.] One hundred and thirty-one bushels stand to his credit, and our three thousand boys in Ohio this year in the corn contest will average 
eighty bushels. The ten-year average in Ohio is about thirty-five or thirty-six, and we have got a whole lot of boys in Ohio who are forty or fifty bushels better than a man, and that is good.

The next boy is John Robinson, a squire of Pennsylvania. This young man is the champion corn-grower of Old Pennsylvania in the year 1913. [Applause.] We learned about his little victory, and we are doing the same thing for the boys and girls in Ohio, and when we learned about this young man, we had him meet our train at Altoona, where we picked him up and he has been with us ever since. He is a manly little fellow, and Pennsylvania ought to be proud of him, because Ohio is. Three years ago he was out in Ohio, one of our boys, going to school there, you know. [Applause.]

I want you to give the boys and girls the right kind of encouragement, get them inspired with the desire to want more of the knowledge of farming. When we take these three thousand reports, we tabulate them, and put on the outside the boys who tested their seed and get their average per acre; then we take the boys over here who did not test the seed and get their average per acre, and then we have got the best proof in the world that it pays to test seed corn, and so forth with tillage and fertilization. Don't you know that it is just a splendid thing to have six trains start out of Ohio last Monday, stopping here and there picking up a car load of humanity. That was a splendid thing. Then, coming to the national capital, and standing at the tomb of Washington. It was the cornfield and kitchen that gave them that honor, and that opportunity, and when I asked the boys to give a vote of thanks to the old farm, you ought to have seen the lot of caps come off and the cheers that went up. It counts. That is what we are doing in Ohio.

I think I have talked about two minutes longer than your Chairman asked me to talk, but it is something that has got hold of Ohio, and it ought to get a hold of you. Go right back and give encouragement to the boy and girl who is doing the business. Much obliged.

Mrs. Smith at this point introduced Mr. Pierce, of Maryland, who said that he was a little ashamed of what they had done in Maryland after hearing some of the Ohio people. He explained the different processes of raising corn in Maryland and outlined the excellent results that have been obtained therefrom.

Mrs. Smith then introduced Mr. Thorn, Director of the Experiment Station, in Ohio, who spoke as follows:

Mr. Thorn: Mr. Sandles has told you that the average yield of corn in Ohio is 35 and 36 bushels. It was that fifty years ago. It has not increased in that period of time. Our average yield of wheat is $141 / 2$ bushels. Fifty years ago it was 121/2. We have gained two bushels of wheat in half a century, largely owing to the increased use of commercial 
fertilizers in our state during the last twenty-five years of this period. At the experiment station we have a splendid series of experiment, the most extensive series of field experiments in the western hemisphere or in the world. We have been showing for the last ten years that it was eminently possible and practicable to double, or nearly double the yields of corn and wheat in Ohio, and do it by measures within the reach of every farmer within the state. We have made an effort to reach the average farmer within the state. There are 275,000 of them in Ohio. Of that number, 65,000 have thought it worth while to waste a postal card in requesting the bulletins of the Experiment Station.' They will not come to us; they will not listen to us; and you have the same history in Pennsylvania. Mr. Sandles, however, has solved the riddle for us. He has cut the Gordian knot by getting past the farmer to the farmer's boy, and through the farmer's boy we are going to reach the farmers of Ohio; we are going to revolutionize the agriculture of our state within the next ten or fifteen years. I thank you.

Mrs. Smith: We have with us Mr. Agee, formerly of Pennsylvania State College, but now with New Jersey. We would like to hear from him.

Mr. Agee: Mr. Chairman, Ladies and Gentlemen: I would like to make the claim and a true one that I am a Buckeye, because I am very proud of my native state, Ohio, this evening. I am proud of the fact that in our state of Ohio we have such co-operation in all of our agricultural agencies, and that there is no overlapping, that the money is expended in the wisest way, and that the state is as a unit promoting the art of agriculture. I have a right to feel proud, as I spent my boyhood and many later years in my native state.

Now, my good friends, your Chairman has insisted that I appear before you, but really I have no special message. It seems to be a time for congratulation that we are awakening to the fact that we have the science that relates to agriculture; that we can interest our young people in it; and that they will naturally go back to rural life, because there is a science connected with it, because there is opportunity. I believe everybody in this world should work. Most people must work. I would like to see all of our boys and girls have an opportunity while in school to get some training to travel along the line of their natural bent. I believe onehalf of the boys and girls of this country would naturally turn to rural life if they believed there was opportunity in it. I believe the schools should use for training subjects some of the knowledge which shall enable that fifty per cent, if I guess aright, to grab a-hold of the world's work when they go out in the rural districts, rather than in the centers of population.

You talk about the drift to the cities, and you deplore it, but the only possible thing to do is to give that fifty per cent of our youthful population their rights, which is a knowledge of the science which is concerned with rural life. A little bit of knowledge will enable them to get hold of the 
work as they leave school, and most of them will get no further than the High School - a knowledge of the standing, a knowledge of the intellectual standing, and that it is possible for them, if they want to, to master the sciences that do concern the soils, plants and animals. You can stop that drift to the city, that should not occur, by letting those who are nature lovers have an opportunity for such development that they will naturally turn where they belong - to country life. You have many speakers. That is a distinguished row of talent on the front seat, every one of them almost, old friends of mine for 25 and 30 years back. You do not want to hear from me. Mrs. Smith has many speakers for the evening, anyway. I am glad of the chance of coming before you. I am part Pennsylvanian also. The happiest years of my life were spent in Pennsylvania, at Pennsylvania State College, where we had the fun of seeing the courses in agriculture grow, and a school of agriculture built up, that, if you Pennsylvanians will support aright, will become one of the greatest agents for good in all these United States. It is going to turn the youth of this state towards rural pursuits as they never have been before. I thank you.

Mrs. Sмгтн: I will ask Mr. McDowell, of Pennsylvania State College, to speak to us and tell what he is doing in extension work; and to tell you also what we could do if we Pennsylvanians got awake after the conference and support the extension movement as it should be supported. 


\title{
AGRICULTURAL COLLEGE EXTENSION SERVICE.
}

\author{
By Professor M. S. McDowell, \\ Pennsylvania State College, School of Agriculture.
}

Ladies and Gentlemen: Some time ago, when land was cheap and the cost of living was comparatively low, the farmer was a negligible quantity except possibly at certain seasons of the year. Today he is a very much sought-after individual.

I have been much interested in the splendid showing made by our friends from Ohio. I am sure that the young men and women they have brought here will be an inspiration, not only to Ohio people, but to we Pennsylvanians as well.

Mr. Agee referred to the fact that there has been developed much information along scientific lines. This information has been developed from many sources. The Experiment Stations have had a large part in developing that information. The problem of the extension work is to get this information before the farmers in an efficient way. In the extension work which we are doing at State College the aim is not only to assist in increasing production but to increase it at a greater net return for the farmer. Any business man, when he puts additional money into that business, is putting it in with the idea of reaping a reasonable profit on that extra investment. So it is with the farmer. If he makes two blades of grass grow where one grew before, he must do it with a greater net profit. It is not altogether simply a problem of growing more than had been grown before. The educational factor is a large factor in increasing those net returns. There are other problems involved, some of which have been discussed here. Even in connection with problems of distribution, the educational factor is a very large one.

I want to take a short time to tell you what we are doing in the agricultural extension work in Pennsylvania. In the first place, we have a winter course in agriculture designed for the young men and young women who do not have the time or money, and who are not prepared to spend four years or two years in training for their lifework, but who can spend twelve weeks during the winter months in getting some training.

We now have 176 students. Six of them are women. In three instances men and their wives are taking the course. The work is arranged by subjects so that the individual may get the things in which he is interested. If he is interested in dairying he can take work along that line. Those interested in fruit can take branches relating to horticulture. Some 
will be interested in general farming. They can choose the particular things that they need. The student is given some practical science which underlies his business that he can take back and put in use on his own farm.

It may be rather interesting to know that of the 176 pupils there this year in the short course, 15 of them were there last year taking the course and came back again this year to get subjects that could not be given to them a year ago. The increase in numbers this year is one-fourth to onethird more than it was last year.

During the year we have Farmers' Week. This is offered to place the facilities of the institution at the service of the farmers of the state so that the farmer himself may go to College for at least a week. It is necessary to hold this meeting at a time of the year when the regular students are away from the College in order to accommodate the people. The meeting the present year will be held December 29 to January 3. Over 150 lectures and demonstrations of practical interest and value to farmers will be given. The faculty will be assisted by well-known experts from outside the state. It gives me pleasure to state that one of them is a pioneer in agricultural research. He has done as much as any other man in this country towards the upbuilding of agriculture. I refer to the gentleman whom you had the pleasure of hearing from a few minutes ago, Director Thorne of the Ohio Experiment Station.

Last year we had 700 farmers in attendance and we hope this year to double that if possible. They represented 59 counties in Pennsylvania and we hope this year they may represent 67 counties of the state.

We also maintain correspondence courses. There are 36 different courses in agriculture offered by correspondence. These consist of a series of lessons. A list of questions accompanies each lesson. Another lesson is not sent until the list of questions which has accompanied the lesson is returned and the answers are corrected. The answers are marked wrong if they are wrong and if it seems necessary comment is made by underlining in red ink so that when the papers go back the student will see where there was error. This enables the instructor to keep in close touch with the students.

It may be interesting to know that 4,000 students are pursuing the work in these courses at the present time and 60 per cent of those who start the course finish it.

For a number of years we have been sending an exhibit to the county fairs. The county fair should be primarily an educational proposition. The exhibit that we send shows the result of some of the more important experiments conducted by the Experiment Station and the practical application of these results to farm practice.

In addition to the educational exhibit stock representing various breeds of dairy cattle, beef cattle, sheep and swine are exhibited. We have been sending within the last year accompanying each animal a card pointing 
out the good and bad points. The exhibit is prepared in duplicate. It is housed in a large tent 30 by 80 feet. Last fair season 14 fairs were visited and 500,000 people passed through the tents. Two men from the College accompanied the exhibit. These men met the people and answered inquiries. Thousands of farmers were gotten in touch with and thousands of questions were answered.

There are many requests for examination of farms and advice. These requests are met so far as possible. Within the last two months or two and a half months, thirty such requests have been met. In instances of this kind those asking the service pay the traveling expenses of the examiner.

Pennsylvania is a great dairy state. We try to serve the interests of the dairyman. One man gives practically all of his time to visiting individual dairymen of a community, discussing problems with them and trying to form a cow testing association. Such an association makes it possible for a dairyman to know what each animal in his herd is doing. They may be enabled to buy feed more economically and enabled to feed their cows to better advantage and reap a larger net profit.

There is not time, however, to go into the testing question.

We have had a number of excursions to the College. The Pennsylvania Railroad ran three in June of last year and brought 1800 people. That enables us to get in touch with the farmers in a manner that is not possible in any other way. It enables the people to see the direct relation between science on the one hand and practice on the other. By looking over the fertilizer plats they can see the remarkable differences. They could go out in some of the fields and see what the result of practical application of these results to those fields were. It enables us to get in closer touch with them and be of more service to them.

One of the movements that has been referred to in extension service is the county agent work. There are nine counties in Pennsylvania in which county agents have been placed. They are under the supervision of a state leader who is a member of our extension staff. There has been considerable discussion of the county agent here and I shall not take time to discuss it now except to say it gives personal touch which is necessary to do practical work.

I would like to take a minute to call your attention to one or two things that have been accomplished by the county agent. I have in mind one county agent where recently, in a public institution in that county, the feed bill was reduced fifty per cent at the same time the milk flow was increased. Another instance: An agent from one of the northern counties, where corn does not grow so well, sent some samples to be entered in the contest here this week. I would like right here to take this opportunity of congratulating the Corn Exchange National Bank for the work they are doing in organizing this corn contest. There is nothing that stimulates interest like competition. A county agent in one of the northern counties 
sent some samples of corn to be entered in this contest. They had in that northern county two classes of corn. This corn won one first prize and one second prize. That shows some of the things that it is possible to do. The College has had some little part in the organization of boys' corn contests in Pennsylvania. We have not been able to accomplish as much as Ohio but if all the boys engaged in such work were organized and gotten together there probably would be close to 1,000 of them. The county agent in Lancaster County was in touch during the year with 700 boys; Mercer County had 200. So while we do not equal Ohio we are doing something along that line.

There is a great demand for speakers at agricultural meetings and conferences and for judges at fairs and similar meetings. All these demands are met so far as possible.

The correspondence that goes through the Extension Department is very heavy. Thousands of letters are answered yearly in reply to inquiries. In a general way this covers what is being done in the Extension Department. As to what may be done we have found by experience that the most satisfactory way of accomplishing results is by direct contact and concentration upon the chief problems of a community. We found that we were reaching the farmers in eastern Pennsylvania to a greater extent than the farmers in western Pennsylvania. In order to get around that we decided to hold a Farmers' Week in western Pennsylvania. For four or five years we have been holding those meetings in western Pennsylvania. Some of the main problems have been persistently emphasized and practical results can be seen from these meetings. There is no reason why the same thing could not be accomplished in every county and in every district in the state.

Probably the thing that offers the greatest field for development is the development of the county agent work to which reference has been made. Nine counties have been organized and there is a demand from several additional counties to have county agents placed there. There are no funds available at the present time unless raised entirely by local people. This will mean eventually that Pennsylvania will be organized with agents in every county or district. It will mean that in addition to the present state leader there must be district leaders who will have charge of certain counties in order that the work may be properly supervised.

All of this work involves an immense amount of labor and patience, and I say the latter advisedly. I would like to strike this note here. There is a great demand all over the country today for county agents. This movement is not limited entirely by the lack of funds but just as much by the lack of men prepared to do the work. It is easy to get men but it is not easy to get men who will fit into the situation. It is unwise to put a man as a county agent into a county unless he is capable of carrying that work to a successful conclusion. They must be prepared to do it and it can grow only as the men are prepared to do it. All this is going to require a 
great amount of labor, patience and a large amount of money. The labor we can get; the patience we must have in any event; whether or not the money will be available depends upon those for whom this service is being rendered.

In closing I desire to call your attention to the fact that some of you may be of great assistance in the matter of the bill that is pending before Congress at the present time. This Lever Bill (House Bill No. 7951) provides for national funds for each state for carrying on this extension work; $\$ 10,000$ is appropriated outright to each state. In addition it provides for an initial appropriation of $\$ 300,000$ to be distributed among the several states in proportion that the total rural population of that state bears to the total rural population of the entire country. I think Pennsylvania's percentage would be a little over six per cent. This amount is increased annually for ten years. It further provides that each state must duplicate the appropriation before it becomes available. A word to your Congressman or Senator may assist in bringing the early passage of that bill.

And finally I wish to take this opportunity of expressing our appreciation to the bankers of the state and to all the others who are in attendance at this conference for the very valuable and helpful service rendered during the campaign before the legislature last winter.

Mr. Calwell: How much money did you get from Harrisburg previous to the last Assembly for extension work?

Mr. McDowell: There was no money appropriated specifically for extension work. The money used for extension work was taken out of the general maintenance, but last year was the first time that the legislature made a specific appropriation for extension work $-\$ 20,000$ for two years.

Mr. CALwell: $\$ 10,000$ for each year?

Mr. McDowell: Yes, that is what it amounts to.

Mr. Calwell: You cannot do very much work on that.

Mr. McDowell: No; supplementing that, in addition to the present funds, we will have to have about $\$ 18,000$, all told, because in addition to the half of the $\$ 20,000$ there has been some money taken from the general maintenance for extension work during the present year.

Mrs. Sмiтн: What did New York get last year?

Mr. McDowelL: I think New York is spending in the neighborhood of $\$ 500,000$ a year in extension work.

Mr. Calwell: How many counties have farm agents?

Mr. McDowell: Nine.

Mr. Calwell: How many counties have we?

Mr. McDowell: Sixty-seven. 
Mr. Calwell: We have sixty-seven counties and have but nine county agents in sixty-seven counties.

Mr. McDowell: Yes.

Mrs. Sмiтн: Our association fought a bitter fight last winter to get the legislature to take notice of this situation. The bankers also did something for the situation, and they are going to do a great deal more in this matter, I am quite sure, in the future, so it is up to the farmers to demand in this state, as they did in New York, that an appropriation shall be made. It is not the legislature that is at fault; it is the farmers. The legislature will do what you want it to do; it will not do anything else. If you don't care, the legislature does not care. It is up to us farmers. We need the things for our children and it must be done in this state. There is nothing more critical.

We are now going to call upon Mr. Benson. We have been stealing his time right along, and we are going to stay a little later to give him a chance to show his slides. 


\title{
BOYS' AND GIRLS' CORN AND TOMATOES CLUBS.
}

\author{
By O. H. Benson,
}

Specialist in Charge of Club Work, U. S. Department of Agriculture, Office of Farm Management.

Mr. Chairman, Ladies and Gentlemen: I have bəen delegated by the U. S. Department of Agriculture, and invited by your Program Committee, to appear this evening in further support of the boys' and girls' club work. My department at Washington will expect me to say and do enough to warrant the expense of sending me here, and your committee will expect me to say and do something. It is already late and time for most of us to seek our "trundle beds."

If I presume to keep you a bit later tonight than it is your custom to remain out, no doubt you will forgive me under the circumstances.

During the past few years it has been my duty to travel much out into the states in the interest of boys' and girls' club work. With the exception of Ohio, all of the regular and national club work has been in co-operation with and through the extension departments of the colleges of agriculture. We recognize that the state colleges are the legitimate institutions through which the regular state extension work in agriculture should be performed. In the support of this position the U. S. Department of Agriculture has been paying one-half the expense of one or more state leaders in each of the twenty states in club work. This leader is selected by the college authorities and is directly supervised by the head of the Extension Department; such arrangements have been perfected in twenty states in the Union; all the Southern and the following in the North: Massachusetts, Michigan, Indiana, Iowa, Nebraska, Utah and Oregon. In addition, we have tentative arrangements through the appointment of club collaborators in the following states, who are all ready for the Federal half-and-half plan, as soon as additional funds are available: Connecticut, Rhode Island, Minnesota, North Dakota, South Dakota, Idaho, Washington, Kansas and California.

We appreciate the fact today as never before, that if we are to have a constructive agriculture, a permanent and promising rural life, we will not make much headway by devoting all of our time, energy and money in talking to and in the instructing of the adult farmers. Unfortunately, many of the adult farmers now on the firing line have too many years of habit back of them. And second, they have too much of prejudice for a free and efficient use of the newer ideas in agriculture and farm management values. On the contrary, the average American boy is open minded, has 
an open heart and has a whole lifework ahead of him. When the follow-up instructions are furnished, they will be accepted as a whole, and not with the proverbial "grain of salt;" but earnestly and with all his heart, the boy translates the pages of instruction into action upon the acres and for the good of agriculture.

This is exactly the reason why the young people from the states in the past, as well as for the present year, have a record of real achievement, and these boys before you tonight, the one from Ohio with a report of over 130 bushels of corn to the acre, and the boy from a Pennsylvania county, with his yield of 144 bushels. I congratulate you, boys, for this achievement, and for what you have contributed to your community and state, for the good of agriculture. The Pennsylvanians will be interested to know that another boy, by the name of Charles Yohe, of Tower City, made a yield of nearly 200 bushels of corn to the acre during the past season, and that he will doubtless be the champion in the club work for the entire State of Pennsylvania. [Applause.] Charles Yohe has not only submitted his official report, but has had it properly attested by two disinterested witnesses, and it shows a handsome net profit on investment. It is necessary at this point to make an explanation-the two yields above reported from your own state were both made based upon field measurement of ear corn. Both of these yields will be very materially reduced when the airdry 56 lbs. of shelled corn per bushel rule is applied as the standard. The 144 bushels will probably be 100 or less, while the 200 bushel record, when thus reduced, will probably be in the neighborhood of 115 or 120 bushels.

Ladies and gentlemen, at the present time America is unfortunate in the fact that she does not have a definite American type of farmer. We have the German farmer, the Swedish farmer, the Dane, the Irishman (most of these, by the way, are farmer policemen), and from these various European countries we have been extremely fortunate in securing the types that constitute our most enduring and economical type of farming. But you and I will have to search the map over very carefully to be able to find even a small settlement or community of the enduring and constructive type of American farmers, to which I refer. There are perhaps a few small communities in eastern Pennsylvania that will come more nearly meeting the requirements of American farming than any other section of our country. The hope of a nation is in her youth. We must deal with them in the springtime of life, at a time when their hearts and minds are open, and when habits are being formed, and out of this type of childhood to develop the type of farmers and righteous citizenship of which a nation might well be proud.

Friends, in addition to the club work and splendid enrollment reported from the State of Ohio, and their splendid list of achievements in agriculture, you will be interested to know that for the past eight years the United States Department of Agriculture, in co-operation with the states, has been developing this club work from an enrollment of 162 
for the first year, up to an enrollment of over 200,000 for the current year. This enrollment represents the work from 32 states, and does not include the enrollment from Ohio. The enrollment from the State of Ohio has been cared for, and the club work conducted entirely from the office of Commissioner of Agriculture at Columbus, and we have had absolutely nothing to do with the Corn Club work of this state. This club enrollment in the 32 states has been receiving carefully prepared follow-up instructions throughout the year. The instructions are written for the child mind, and directed in small installments to the club members once a month, when the special instruction is needed on a particular phase of the work. In addition to the instructions sent by mail, 20 of the states have state agents in charge of club work, who co-operate with the county superintendents of schools, county agricultural agents and other local leaders, in giving the membership the necessary follow-up work in the field, such as holding monthly meetings, both in and out of doors, visiting the club plats and club members, commending and instructing them as necessity demands. The two most important factors in these activities are careful follow-up work and final results, which has most of its value, perhaps, in the business estimate, viz., the net profit on investment. You business men, I am sure, agree with me that every club plat should be a definite demonstration, and illustration of good business farming, and we should have a deeper desire than merely instructing the boy, giving him a prize for achievement, free trips, and telling his story through the public press. It seems to me that the greatest good to both the boy and his agricultural environment, is when the entire agricultural community can adopt his method of corn farming safely, and at the same time pay for baby's shoes, meet the grocery bills, and lift the mortgage on the farm.

It is indeed encouraging to see how many of the business men, grange organizations, commercial clubs, federated women's clubs, are not only giving of their money, but of their time and interest, in the promotion and conduct of this work in all the states. Some of the federated women's clubs have been very active in encouraging the Girls' Garden and Canning Club work, to the extent, not only of assisting in the enrollment, visiting the club girls at work, raising prizes for their encouragement, but in actually finding a market for their canned products, which are being sold all over the United States, under what is known as the 4-H Brand Club Label. The object of the label, of course, is to standardize the products of the club members, and guarantee to the public a sanitary, high quality, and full pack, and only club members who meet these requirements are entitled to its use. In addition to this, we have the 4-H Brand Seed Corn Label, the 4-H Brand Seed Potato Label, free use of which is offered to club members in these two lines of work who will meet the standardization requirements. These labels are available to the regular authorized state, district and county agents who represent the co-operative work of the Federal and State Extension work. 
One local secretary of a woman's club, when invited by the state agent, gladly accepted the charge of a group of 18 girls in her community. She visited these girls on an average of twice each during the year, provided the premiums and through her local club secured a market for all of the club products. Mrs. W. H. Gilbertson, wife of the county agricultural agent in Sussex County, mothered the girls' club work in the county, did practically all the work in the interest of the girls, and one of her girls was a champion of the state, in this particular line of work (her name was Miss Lucy F. Bale) with a production record of nearly two ton of tomatoes, from a one-tenth acre plat. Her net profit on this piece of ground was $\$ 70.00$. The most important part of her work, however, was the work with a little portable home canner. Through this little labor-saving device she was able to transform the cheap product of her garden into a staple product, capable of demanding on the markets of the world a uniform price throughout the entire year.

Mrs. J. K. Turner, of Cleveland, Ohio, a well-to-do and a leading society lady of that city, directed a letter to the Department of Agriculture, and asked for suggestions as to what she could do, of a worth-while character, for the girls of Geauga County, Ohio, and wanted especially some information in regard to the girls' club work, which she had read about in some of the papers. She asked for and insisted upon the United States Department of Agriculture giving her definite help in getting this new line of work started in her county. She agreed to do all of the work of supervision, organization, and encouragement, and furnish a liberal amount of prizes herself, if we would give the initial instructions in home canning to the girls, and to furnish to them the follow-up instructions throughout the year. This woman, without a dollar to reimburse her for several months of hard work, at considerable additional traveling expense, as well as the expense of banquets, picnics, receptions, prizes, etc., organized a c'ub of 126 girls. She not only organized them, but visited every girl several times during the year, invited them to her home, gave receptions to them, and paid the expenses of a free trip to Washington for the four champions. Mr. and Mrs. Turner and their two daughters, Nona and Norine, accompanied the champions to Washington. Mrs. Turner and her daughters played the game with the girls, from A to Z, walked to the top of Washington Monument with them, in order that they might understand more fully the distance from the base to the top, as represented by this Institution. I am narrating these facts in order to show you that there are a lot of people, who not only talk better agriculture, believe in it, but who are willing to render personal service, and spend considerable of their money in this regard. Mrs. Turner drew upon the bank to the extent of over $\$ 1,200$ in cash output for the encouragement of this work. I like folks who are willing to give of their time and money freely to a worthy cause, and I want to say right here, that there are some of your people in Philadelphia who have spent a great deal of money during the past year for the good 
of agriculture in the central East, and they are to be commended for this, and congratulated for their liberal support of constructive agriculture.

When we stop to consider, as reported by Secretary Houston, that at the present time only 12 per cent of our land in the United States is yielding in maximum production, and only 40 per cent of all of our acres is being farmed at all, and that 60 per cent of all the land in this country is practically idle, doing nothing for humanity, making no effort to reduce the high cost of living (a problem which concerns us all), and represents a waste in American rural life which cannot be easily computed in dollars and cents, and then when we stop to consider still farther that 50 per cent of all of the fruit and vegetables grown in this country from year to year is wasted for want of proper knowledge of grading, crating and marketing products, of a sure, efficient and labor-saving method of canning the surplus, and for the lack of appreciation and adequate means of refrigeration, I am sure that Dr. Pennington, from our own department, who has so ably discussed the merits of refrigeration, appreciates the fact that only a very small per cent at best of our people will ever have available the facilities for refrigeration work, and that for the other class of people it is important that we offer them substitutes that will work, and will help them relieve the situation for the present at least. I know of nothing better to offer at this time than this home canning work. Through the Girls' Garden and Canning Club work, the people are being taught to go into orchard, garden and field, and can the surplus. All kinds of fruit, all vegetables, greens, sweet corn, windfall apples, etc., can be successfully transformed into a canned product through this inexpensive home-made or commercial portable outfit, and can do the work as well as the commercial factory. There will be no danger of white mould, and the hard things to can, like sweet corn, beans, peas, greens, and even meats, can be successfully put up by the boys and girls, ranging in age from 10 to 18 years, with definite success. These little commercial outfits are of four distinct types - the hot water bath, the water seal, the steam pressure, and the aluminum presser cookers. The commercial outfits cost all the way from $\$ 3.25$ to $\$ 16.00$, according to the size and particular type required. A child can put up 300 cans of tomatoes with one of these little outfits in a single day. An adult can put up 600 cans in a single day. The average cost of producing a can of No. 3 tomatoes, including all the items of expense, such as labor, rent of land, cost of cans, label, etc., is only 4 cents, while this same can with a similar quality of product will command a price of from 10 cents to 18 cents a can.

Here is an interesting story of a can of tomatoes: While in Colorado last July, I visited a grocery and purchased of the merchant a No. 2 can of tomatoes, and paid 15 cents for it. I was so interested in this can of tomatoes that I reviewed carefully the label, made inquiry of the names and addresses of all of the companies, business concern, commission merchants, canners and growers, who had been identified with its evolution and migration from southern Maryland to this western state. When I 
had trailed it all out, I found much to my surprise, that this can of tomatoes had been the property in turn of all of the following concerns: the retail merchant, a jobber at Denver, a wholesale house in Chicago, a wholesale house in New York City, a commission agent, a canning factory in southern Maryland, whose label appeared on the can, another factory in Maryland who had actually put the product up in tin, and sold it without a label, and lastly the grower, who had sold the product at the rate of $\$ 8.50$ a ton. Now, I am sure that you people, like myself, appreciate the fact that we need, and always will, a few middlemen. They are legitimate, and as important as the almighty dollar, in the business life, but when it comes to identify a whole bakers' dozen of middlemen with one little measly, insignificant No. 2 can of tomatoes, it is swinging the pendulum too far, and there is no argument in its defense. It is possible that two of these were legitimate, between producer and consumer. The rest of them ought to engage immediately in farming, or some other helpful line of service, and help this country of ours to get a square meal at a reasonable price. This story offers a definite argument for home canning in every community. If the average cost of a can is 4 cents or less, and the retail price is 15 cents, you have a middleman's difference of 11 cents. Then the child who can can 300 of these cans in a single day, can actually earn $\$ 33.00$ cash per day, for every day spent in eliminating the waste of orchard, field and garden. An adult working at the rate of 600 cans per day can turn out a net profit of $\$ 66.00$ cash, for each day spent in this constructive line of work. You ask, does it pay? No one doubts the fact that there are but very few average people who are making a better cash return showing per day than is offered through this line of work.

When I say that children can do all of this canning, do it all successfully, with the saving of time, labor and yet do it more efficiently and at less expense than has been true in connection with the old open kettle method, practiced in most of the homes throughout the country, some of you will necessarily doubt the honesty of my statement, and for this reason, I regret that I am not invited and have not been given time to actually demonstrate with the outfits in the canning of the various vegetables and fruits. My usual method of demonstrating the facts in this home canning work is to bring the equipment before the audience, invite a few of the little girls and boys in the audience to come forward and be instructed in a few moments' time, and then in turn to demonstrate how easy it is to perform the operations in the canning of strawberries, so they will keep flavor, color and texture; beans, peas and greens, so that they will not only keep color and be fresh for service, but will be a part of the balance ration for every day of the year, and eliminate the necessity of patent medicine, so common in the American home, and that these same children can learn to successfully can sweet corn on the cob, by simply using a little water and salt, and have fresh ears of corn for Christmas dinner, to which friends and loved ones may be invited. This kind of canning is usually done in a 
gallon tin ean, which will hold from five to one dozen ears of corn, per can, and I take it that the average Pennsylvania family is not too large to get along very well with one can to the meal. Most of you have come expecting to see all the lantern slides to illustrate this work. Owing to the lateness of the hour, I am forced to leave out a large number of them, and to leave much unsaid, in connection with those that I use. My system is full of this club work, and I always regret that time is too short to get it all out and thus relieve my mental tension before I leave the floor. $\mathrm{My}$ first experience in this line of work was some 14 years ago in the State of Iowa, where I had my initial experience, in seeing the benefits of club organization work with young people, and its influence upon the adults of the community, and since that time, I have been doing more or less of this work every year, and the longer I work at it, the more of constructive value I see in this activity for a greater American agriculture.

The boys and girls during the past year have been at work in at least one of the following activities: corn club work on the acre basis, potato club work on the $\frac{1}{8}$ or $\frac{1}{2}$ acre basis, garden and canning club work, vacation canning and marketing work, poultry clubs, good roads, alfalfa club, sugar beet clubs, etc. And then some of them are engaged in what may be called a pig club. My idea of this line of work is that the best way to organize a pig club is to grow an acre of corn and raise a pig along with it. Otherwise, this boy's pig is liable to "sponge" on some of father's corn and feed rations. One very important thing in connection with this club work is to have these children understand that you are requiring of them a business undertaking, a job like that of the father's, or a man's job, and they will be proud of their work and will be glad to measure up to your requirements. The nearer we can come to this manly or womanly ideal, the more nearly we have the enduring thing to offer the boys and girls. Some people confine their efforts in club activities which are mere school exercises and to the making of a big yield, without any regard to economic production, and this usually encourages excessive use of fertilizers, and in many instances the yield has been made at a loss rather than on a net profit. While in county work in the State of Iowa, I had one experience of this character, that taught me a lesson that I shall not soon forget. The champion boy with a great big yield was severely criticised by all of his farmer neighbors, because he lost over $\$ 11.60$ in his business transaction. One very prominent and influential farmer of that same neighborhood came to me and said, "I, too, could make a great big yield of corn, if I did not have to pay for the bread and butter, clothing, schooling and general expenses of my family," and charged me with the thought that I had given the boys in the county the improper ideal, and had hindered rather than helped agriculture. From that day to this, I have been talking and working on the other basis, viz, the business unit, and with scme emphasis on the net profit on investment, and I find in this connection, that if I wish to secure the greatest benefit to the boy, culturely, ethically, or even spiritu- 
ally, it can be better done through the latter method, than by the slip-shod method of yield only. The basis of award in the corn club work, in the 30 states which have federated, is based upon the following points: yield, 30 per cent; net profit on investment, 30 per cent; exhibit and quality of products, 20 per cent; crop report and story of how I made my crop, 20 per cent. This standard was not the one set by the United States Department of Agriculture, but unanimously accepted by the state leaders of all of these states, as the best workable basis, for the good of the boy, as well as for the good of agriculture. This will encourage the very thing that will be accepted and appreciated by both business men and farmers.

While passing through an eastern town, not long since, a friend of mine hesitated on the street corner and said, "Do you see that group of boys over there? Do you notice that they are all using tobacco in some form? One little boy about twelve years old has a cigarette in his mouth, the others either pipes or cigars. I cannot understand why every boy in this town seems to have for his chief ambition the use of tobacco." I said, "This is easily understood. Those boys want to be men, and it is because the men of the community practically all use tobacco in some form, and they recognize at once that one of the easiest things they can learn to do that looks like a man's job is to smoke a pipe or learn to use tobacco. Get your men to quit and make it unmanly, and the boys will all quit, without a word of mouth, or special effort on the part of social workers." Understand I am not endorsing the use of tobacco, but I am pointing a general principle that should be followed in the teaching of girls and boys industrial activity. I know what I am talking about in this regard, as I once was a boy. My father's personal friend was a banker, and when my father came out of the bank, arm in arm with this banker, both of them with cigars in their mouths, and both of them were men that I believed in and admired, the first germ of "Oh, to be a man," dawned upon me on that particular day and my first manly effort with a cigar was tried back of the barn. Sick-yes, just a few times, but what does an American boy care for tribulations of this kind if it makes him look like a man, in the end! And for the encouragement of the boys present may I add that since I became a man I put away childish things. And since my twentieth year I have never used tobacco in any form. Boys, I want you to take a whole acre, and more if you can, for next year, and, like the best farmer in your community, prove that it is profitable to grow corn, select seed corn from the mother stock, string your seed corn and market it under the 4-H Brand Label.

I have a notion to close right here and not show you any more slides. I have enough of dope on slides and charts to keep you here all night, but I want to leave you in such a way that I may have another invitation to your gracious community. Let me urge that you all together put your shoulders to the wheels of agriculture and home economic progress in the State of Pennsylvania, and encourage the boys and girls to enter 
this work for next year. The most economical, as well as the surest and quickest way, to make of your state a great agricultural as well as a.commercial state, is through the boys and girls rather than through the adults. These young people with a lifetime ahead of them, all of them in need of vocational guidance early in life, furnish for you and your money unrivaled opportunities for great service. In addition to investment of money, put into this work some of your personal service. After all, this is our greatest contribution to any line of work. The Good Book says, "A little child shall lead them." And the truth of this was very ably illustrated by the child-Christ at the age of twelve, when He stood among the learned doctors in the Temple. When He was questioned by His parents why He had lingered behind, His prompt reply was, "Wist ye not that I should be about my Father's business?" In this statemenc, He sounded the serious message for the boys' and girls' club work of today, and $\mathrm{He}$ Himself went about doing His Father's business while but a mere boy. In serving as an apprentice in His father's carpenter shop, carrying the water from distant well to his mother's kitchen, hoeing the row in the back yard garden, clearing the rubbish from the dooryard, running the many errands, playing with the neighbor children, and doing the one hundred and one other things common to child life. In and through these activities the Christ-child became the Chrisl-man, equally trained in head, heart, hands and health. A four-square training to meet the foursquare needs of all time.

[This lecture was illustrated by the use of lantern slides and electric chart. The conference then adjourned until 10 o'clock Saturday morning.] 


\section{BANKERS' DAY}

\section{Saturday Morning, December 6, 1913, 10 o'Clock. \\ GENERAL TOPIC: "AGRICULTURAL CREDIT"}

Mrs. Smith: The first matter that I want to bring to your attention is a resolution put before the management of the conference, which I think we all feel interested in.

There has been some trouble about the importation of potatoes into this country. A potato disease is raging in Europe and we are anxious to keep it out of this country. Mr. Calwell feels that for the Corn Exchange Bank and for this conference to go on record as opposed to raising the embargo it would express the sentiments of a part of the country on this question. It is a very important thing to have an embargo on the importation of potatoes remain as it is. I will just read the resolution as it has been worded. It is open to change: "Resolved, That the Agricultural Conference and the Corn Exchange National Bank are opposed to the lifting of the embargo on the foreign potato importation now about to be discussed by the Department of Agriculture in Washington."

Mr. Wescott, you are acquainted with produce lines. Can you tell us why there should be any question of raising the embargo?

Mr. Wescott: I am sorry that our information does not relate to the scientific aspects of this question. Coming from a section, however, in which the production of potatoes is the chief industry, it would be extremely disastrous if any other burden were committed to the farmer in the way that would interfere with the production of his crop.

It seems a fair assumption that unless there were scientific probability of contagion through importation, the embargo would never have, in the first place, been put upon the importation. That being the case, it would seem unwise to take any chances that would result seriously, not only to producing sections, but to this country at large through the importation of any further potato disease. We are very heartily in sympathy with the purpose of this resolution.

Mrs. Sмiтh: Is there any one who feels opposed to that? I think that most all of us feel that it is a good thing to keep out. If there is any person who would like to say a word why the embargo should be lifted, we should like to hear from him.

A Delegate: Should not the resolution state why it should be kept on? 
Mrs. Smith: The reason is so well known, and as the question will be in the hands of the Secretary of Agriculture, it does not seem worth while to do that.

A Delegate: As I understand it, the trouble is in potatoes coming from a foreign country where they have a disease; that the spread of that disease would be very disastrous.

Mrs. Smith: All those who are in favor of passing this resolution will please say aye.

[The resolution was unanimously adopted.]

Mrs. Sмrтн: If you are willing, I propose that you make a motion that Mr. Calwell appoint a delegate from this conference to atten the conference before the Secretary of Agriculture next week.

[A motion was here made that Mr. Calwell be appointed to attend the conference in Washington, which was duly seconded.]

Mrs. Sмiтh: It has been moved and seconded that Mr. Calwell be appointed to attend the conference, and, if he cannot attend it himself, that he shall appoint an alternate.

[The motion was unanimously carried.]

(At this point brief addresses were made by Messrs. Lord, Perry and Pearce, from the State of Maryland, outlining the splendid results achieved by the Boys' Corn Clubs in that section of the country. The young men gave a practical demonstration of agricultural work from a scientific standpoint, utilizing for this purpose a large exhibit of corn which they had brought to the conference. They explained how heredity cuts an important figure in successful corn-growing. Other points that had to do with scientific corn-growing were brought out by the youthful demonstrators, and received close attention.)

Mrs. Sмiтh: I now take pleasure in introducing to you Mr. J. Clyde Marquis, a delegate of the city of Philadelphia to the American Commission on European Agricultural Credits; and Associate Editor of The Country Gentleman. 


\section{THE RELATION OF AGRICULTURAL CREDIT AND CO- OPERATION TO THE COST OF FOOD IN PHILADELPHIA.}

\section{By J. Clyme Marquis,}

Delegate of the City of Philadelphia to the American Commission on European Agricultural Credits; Associate Editor of The Country Gentleman.

The unrest among farmers has been gradually increasing since the Civil War, but it was not until the growing cost of food aroused the city consumer to the situation that any widespread notice was taken of the matter by public men-Congress, the legislatures and the public press. The agricultural press has been full of the discussion for thirty years and there is nothing new about it to those who have been studying agricultural economics closely. The trouble has been that until the present they have not been heard by the public.

Public agitation broke out during the Roosevelt administration and resulted in The Country Life Commission, which was the first popular propaganda directing attention to our agricultural situation. Then David Lubin went a step further. Believing that the trouble at the bottom was a financial one he urged the Southern Commercial Congress to lead a delegation of state representatives abroad to see how Europe had met the financial problems in similar situations. Lubin must have credit for having secured the appointment of the official Commission, which is soon to report its findings to the President and to Congress.

The city man asks, what has all this to do with his grocery bills? Let us analyze by stating a series of facts that are now generally accepted as facts:

1. Food costs have increased. The proofs are well known to every one.

2. The farmer has not gotten the increase in profits which the consumer has paid. Plenty of farmers are testifying to this point.

3. The increased cost for services by distributing agencies in the city now increases the cost of food over the prices received by the producer from $50,75,100$, and in some cases 200 per cent. For the city of Philadelphia the proof has been provided in the investigations of Dr. King, of the University of Pennsylvania, under the direction of Director Cooke of the Bureau of Public Works. 
4. The cost of food can only be reduced in one of two ways:

(1) reducing the cost of marketing.

(2) reducing the cost of production per unit or increasing production, which amounts to the same thing.

The cost of distribution must be reduced by

1. Eliminating duplication and unnecessary service, speculation, etc.

2. Direct selling from producer to consumer.

To reduce production cost involves more intensive farming and more intelligent farming.

Intensive farming requires more working capital-it is primarily a financial consideration at the outset because it requires

1. More labor and the labor cost is 25 to 75 per cent of the cost of production.

2. More fertility-commercial or natural manures.

3. More equipment and higher grade management.

These improvements hinge on making more capital readily available to the farmer and of promoting educational enterprises which will show him how to improve his methods without too great cost.

We can here see the relation of rural credits to co-operation and the food problem.

To reduce the costs of distribution requires co-operation.

1. Co-operation of consumer and producer to eliminate the marketing evils.

2. To introduce direct selling.

\section{What Europe Can Teach Us.}

The recent investigation and previous studies show us

1. That Europe has solved some but not all her rural problems.

2. Her experience is suggestive but her methods are not wholly

- applicable to our conditions.

European versus American Farm Production.-Europe views agriculture from the standpoint of total output per acre and on this basis she greatly excels us. America has viewed agriculture from the standpoint of the labor of the individual and on this basis our farmers are more efficient.

If the yield per acre of all crops were fixed as the standard of the world the average of the United States would be 108 and for Belgium 221 , but if we view it from the standpoint of production per person the figures for the United States are 1104 and Belgium only 508, which means that while intensified Belgium gets over twice what we do per acre the United States gets over twice as much production as Belgium per person, 
which means from the standpoint of the producer the Belgium farmer is much worse off than the American farmer and is by no means so efficient.

European farmers are regarded as a class, and in many cases a class of limited rights and opportunities. The American farmer is a citizen with equal rights with the consumer and cannot be controlled or forced to adopt methods which will improve the condition of the consumer.

European ideas are not new to us. We have successful co-operative creameries, farmers' elevators, breeders' associations, fruit growers' associations, rural credit associations, etc.

In America these reforms will be brought about by three agencies:

1. National laws which will give the farmers' assets standing in the financial market.

2. A favorable attitude on the part of banking interests toward these assets.

3. Co-operation with the consumer.

National laws are now underway and proposed reforms by the Federal Commission are before Congress.

Bankers are aroused and the present meeting is a result of their interest.

City and country co-operation is the keynote of this talk.

\section{Philadelphia's Food Situation.}

Few large American cities are fed from nearby lands. Philadelphia is particularly dependent upon food-stuffs coming from a distance. We must compete with other large cities, as New York, Boston, Baltimore and Washington for this food. To get it we must offer favorable markets and market conditions such as terminal facilities, storage, distributing agencies, etc. This phase of the question is fully realized by public officials and is receiving constant attention.

The lands adjacent to Philadelphia are in many respects not producing 50 per cent of their possibilities and in many cases nothing at all. The city is surrounded by a vast unused area only partially worked.

Suburban values make agriculture unprofitable in most sections within a radius of twenty-five miles and tends to check direct selling by personal contact with the consumer and producer in public markets. Many cities have large food producing sections. nearby, notably Paris.

Philadelphia is dependent upon

1. Encouragement of local production.

2. Direct selling, via parcel post, express, trolley, etc.

To encourage local production there is needed

1. The improvement of surrounding farms.

2. The encouragement of direct selling, which will give the nearby producer the advantage and profit which his location should justify. 
Direct selling, aside from the public market, is an innovation, untested, with many problems.

The farmer wants to know:

1. What the consumer wants.

2. When and how to ship it.

3. Who to ship to-dealers or private customers.

4. Market supplies and storage facilities.

5. Price standards.

The consumer wants to know:

1. What to buy.

2. When and where to buy.

3. His obligations in direct selling.

4. Prices, market surplus and production conditions.

There is no agency at present that can give the consumer this information. Dr. King and Mr. Kates suggested day before yesterday that the only possible solution of that problem was to have a municipal market bureau that would give out this information. It is not an expensive proposition. Under the present situation, the first step must come from the city. Then there should be co-operation of the city with the country. The farmer is on the defensive in this matter, because he can sell out his place. He is doing it in a great many cases. Why is it? Because of this unrest. They want to take a chance of getting increased values. The public is interested in the eastern farms, and getting close to market. We are building up a generation of younger farmers, who will take advantage of a place near a large city. We must have the support of the city in bettering these conditions, which will give the farmers assets and credit, the same as business men. Then we must have educational support, and direct co-operation of the city with the country, if we are to develop food production in this and in other cities.

Mrs. Smith: It now gives me pleasure to introduce to you Dr. J. Russell Smith, of the Wharton School, University of Pennsylvania, who will address us on "The Efficiency Movement and the Farm Problem." 


\section{THE EFFICIENCY MOVEMENT AND THE FARM PROBLEM.}

\section{By J. Russell SMith,}

Professor of Industry, Wharton School, University of Pennsylvania.

Mr. Chairman, Ladies and Gentlemen: Did any of you ever see a Dane? Well, I have, and I want to tell you something about him, and perhaps you will agree with me in it. It is this: A Dane is no smarter than the people of Pennsylvania. Now I have to admit right away that I cannot prove that by looking at our agriculture and at his, for the agriculture of the Dane is far and away ahead of ours. Still, I believe we are as smart as he is, but he has got ahead of us agriculturally in that he has applied the efficiency movement to crop production and selling. Dr. Carver told us yesterday morning how wonderfully they had succeeded in putting up uniform standardized packages of farm products that the world can trust and gladly pays for.

We hear a great deal these days about the efficiency movement, but it thus far has come almost entirely from manufacturers and the factory. It has four great fields, however, in which it must be applied. One is the factory, the second is the farm, the third is purchasing and selling, and the fourth may be called community activity.

What is this efficiency movement? Efficiency shows how. There is a right way and a wrong way, often a great many wrong ways, to do practically everything. The efficiency expert studies, and out of the many ways selects the best way. That is all. Mr. Frederick W. Taylor, of this city, well and widely known as one of the fathers of the new efficiency movement, tells us the story of the cleaning of an engine boiler: $\mathrm{He}$ found it took a lot of time as ordinarily done. He examined into the processes and found that men were lying on their backs, in cramped and awkward positions, with their tools disarranged and out of reach, getting dirt in their eyes, and generally making a hand-to-hand struggle with a bruising job. After carefully figuring out the way it should be done, he printed long and elaborate instructions for the workmen to follow. $\mathrm{He}$ made mattresses to lie on, so that they could put their energies into work rather than misery. The tools were arranged in orderly kits and the operations were systematized and definitely arranged in series, with the result that a saving of over two-thirds of the time resulted. This is typical of thousands of cases that might be mentioned. Factory production is rapidly being organized by the efficiency movement, which not oniy deals with the best way to do particular jobs, but copes with the much greater problem of organizing the various units into a harmonious whole. 
There is an equally great field for the efficiency expert on the farm. Thus far most of the scientific promotion of agriculture has been devoted to teaching farmers how to perform unit operations better. They have been told how to select seed corn, how it should be cultivated, how to fatten a pig, how to spray an apple tree; but a farm is a very complexly organized group of activities, and the problem of their interrelation is well illustrated by the case of Dr. Spillman's farm. Dr. Spillman, Chief of the Bureau of Farm Management in the Department of Agriculture, at Washington, took an old run-down farm in Missouri, got some very efficient units of operation, raised the corn yield from 20 to 80 bushels an acre, but found he was not making much money. Examination showed he had been so impressed with the good unit of corn production that he had little else, and therefore had a great pile of work to be done at the time of the spring plowing and corn cultivation and but little the rest of the year, with the result that the ten work horses ate up most of the profits of the farm. By rearranging his crop system so he had constant work throughout most of the year, the number of horses was reduced from ten to four, and, while the output was not increased, the profits were increased several fold.

There is a right way and a wrong way to do everything. The old way used to be, "get a good man and turn him loose. He'll come out all right." This dependence on genius is giving way before our increasing faith in the results of scientific work that arises from the careful studying out of the best way and then following it.

Just here I want to emphasize the fact in this agricultural conference that the application of the efficiency movement to the farm is more difficult than the factory, for the reason that the farm is often a more complex thing than the factory, using a greater variety of raw materials, turning out a greater variety of products, and using more sciences. Furthermore, this complex and scientific task must be carried on with a small staff, and subject to the restrictive operations of the uncontrollable weather.

But, after the efficiency movement is applied to the farm, what's going to become of the crops? What good does it do us to produce better potatoes if they rot in the ground, or increase their costs three-fold in getting to market? Our whole system is full of just such unadjusted production units. The student of industrial history, for example, tells us that in Revolutionary times the best hand-spinner could make two threads at a time, whereas now power-driven machines enable one spinner alone to make 12,000 threads at a time, a six-thousand-fold increase over the Revolutionary spinner, but does anyone claim that clothing is six thousand times as abundant? This improvement, while rather extreme, is suggestive of hundreds that have occurred in all forms of manufacture, and agriculture has not been neglected. A statistician for the Industrial Commission announces that in 1836 the production of a bushel of wheat required 183 minutes of human labor, while it required in 1896 but ten minutes, a ratio 
of 18 to 1 , but no one claims that bread is eighteen times as abundant. The truth of the story is that we have made mechanical improvements faster than we have learned how to use them. We have the units, but we have not correlated them, and like Dr. Spillman's farm, they are in need of readjustment. I have full faith that in the near future we will have a great increase of the efficiency movement which will enable us to better utilize so many of our new units. We have all of the machinery for a greatly cheapened factory production, a greatly cheapened farm production, and a greatly cheapened carrying of the goods between factory and home and farm and home. It is merely a task of organization and efficiency.

Transport and marketing afford us our present greatest and most monumental waste. We boast of the great speed of modern transportation, but one of its chief results to date has been to get consumers and producers so far apart that much or most of the crop is wasted. We have men telling us with good grounds that the farmer gets but 35 cents of the consumer's dollar and the goods the consumer gets for his dollar are somewhat deteriorated in transit. Here is a great work for the efficiency expert. We have railways and trolley freight, motor trucks and parcels post, and now to utilize all these things we must, like the Dane, standardize production and make marketing so honest that we can buy a package without looking at it. We all know what is inside of a package of Uneeda Biscuit, but most of us are afraid to trust an egg or a barrel of apples until we break it open, after which we take two looks and a smell. A Philadelphian now needs to be able to buy a package of Chester County Farmers' Association eggs and be willing to eat them with his eyes shut. We should buy Bucks County Association sausage and scrapple with equal confidence. We should be able to get Jersey beans in any of our houses before they have been picked twenty-four hours, and be perfectly sure of that fact. We should be able to take a package of oranges and apples from anywhere and know that the names on the outside of them were absolutely correct. Furthermore, we should be able to do many of these things at wholesale and cut out that wicked cost of the myriads of wasteful grocers' wagons that are fooling around the streets with quarter-pecks and half-dozens of things. Two ladies of my town, for one of whom I have the pleasure of paying bills, recently took three hours in the city, and spent $\$ 62.00$ each for groceries. In one hour and a half they were transferred from freight car to the family storerooms. The whole operation actually took less time than would have been consumed by the ordering of the same amount of goods piecemeal by telephone, and the total net savings for each woman were over $\$ 10.00$. We need to put in our cellars and pantries bushels of potatoes and know whether they are mealy or soggy, sacks of peanuts, sacks of pecans, sacks of walnuts, boxes of canned goods, and dried fruit, cases of groceries, etc. All these things should of course go straight from the farmers' and manufacturers' associations of producers to the city and country association of consumers. There is no reason at all why the 
housekeepers' league or even a labor union should not take full carloads of apples or potatoes or cabbages or beans arranged in standard packages, unload them at the nearest siding and have them delivered direct to its members within three or five hours.

It is evident, of course, that such direct dealings of producers with consumers would give better goods and better prices, and thus very materially reduce the cost of living. Naturally it can only come about as the result of organization, organization for marketing, transportation, and distribution. But why should not one of our greatest activities be organized rather than chaotic? What excuse has chaos to continue? It is chaos that helps make the cost of living high. The managers of factories have discovered that they must study and plan to use their machines and tools. The farmer is discovering the same thing in his new movement for improved farm management. Now the communities that are wailing about the cost of living must discover that there is such a thing as community efficiency and we have not got it yet. The tools which the community must use to make itself efficient are all the institutions and groups of people among us - the banks and bankers, currency, railroads, trolley lines, postal service, state experiment stations, the school, the college, commission men, the store, co-operative purchasing associations, co-operative selling associations. All these industrial factors which have been working along independently in a way that is about as orderly as a mob, must come to work together in a new way, which has the correlation of the good baseball play or the good football play. We must have organized activity and it will be quite as valuable as the work of the man who made two blades of grass grow where one grew before, because it will save us from wasting that second blade of grass, which we are now wasting most riotously and uselessly.

Study, reorganization and the elimination of waste motion and wasted time have marked the efficiency movement in manufacture. They must come to the elements of farm activity and to the elements of community activity.

Whose business is it to work out community efficiency? There's the rub. As long as it stays everybody's business, it is liable to remain nobody's business, and the groans about the cost of living will continue. As a matter of fact, it must become the business of the intelligent end of every community. I regard this conference being held under the auspices of a bank and various public bodies as exceedingly auspicious, for it will serve to call the attention of the people who know and have power to the fact that this desirable thing, like practically every other desirable thing, can only come as a result of, and live by the support of intellyent public opinion. This intelligence can make itself felt through the action of the national government, the state governments, county governments, and numerous groups and associations of private individuals working together to promote efficiency in the service of their members and the community. 
The wasters must step aside and the industrial organizer must enter a new field. His first pieces of handiwork promise to be groups of people buying, selling, dealing, directly with each other and rendering services that individuals have heretofore been unable to achieve.

Many desired reforms demand legislation which can only come as the result of years of agitation and perhaps the making over of the race. The application of the efficiency movement merely demands sensible work under existing law with human beings that are now here.

[The conference then adjourned until 2 Р. м.] 
Saturday, December 6,1913, 2 P. M.,
Ballroom, Bellevue-Stratford Hotel.

\title{
ADDRESS.
}

\author{
By Charles S. Calwell, \\ President, Corn Exchange National Bank, Philadelphia.
}

We are here to consider a new banking system. Not merely a system of getting deposits and making loans, but a banking system of helpfulness. This movement is not new. Some bankers in the West have been very active along these lines, but here in the East, until lately, we have been overlooking the farmer, notwithstanding Pennsylvania has the largest rural population of any state and that there is no better farming land than right here in our four states.

We are in this work because we expect it is going to pay us. It is going to pay by increasing the prosperity of this section, but especially it will pay by helping to remove what little prejudice there may exist against banks. It does exist and it will exist as long as we sit in our back rooms and only study credits and think of schemes for increasing deposits. We have long thought that a banker's duty was to hear everything and say nothing. But we have carried it too far. We have been straddling every question. If a Democrat comes in we try to think of some Democrat we once supported. If our customer is a Republican, we change the subject to the tariff, and to get a banker's name on a reform list requires action by the board. I don't believe in mixing in politics, but I believe in taking a decided stand on the questions of the day, especially those questions that affect the general prosperity. Banking business will have to be conducted in the future on broader lines. By helping others we help ourselves, and the sooner we learn this the better for all. Now, a mild and inoffensive way of showing the public that we are not altogether selfish is to help along this movement for the bettering of agricultural conditions. Just as I think that it will be but a short time before large city banks have on their staff an engineer or efficiency expert for constructive criticism of the plants and methods of their customers, so I think the country banks have just the same opportunity for guidance of their customers and their problems.

Mr. Calwell: I take pleasure in introducing Mr. Harris from Champaign, Illinois, who is chairman of the Agricultural Commission 
of the American Bankers' Association, and is measuring up to this great proposition.

W. Inving Walker: Before Mr. Harris takes the floor, I would like to offer the following resolution: "A vote of appreciation is hereby extended to the Corn Exchange Bank of Philadelphia for the inception and assembling at the Commercial Exchange, the exhibit of corn of an exceptionally high grade from the states of Pennsylvania, Maryland, Delaware and New Jersey, believing that by such exhibit there has been an awakening of a deeper interest for a greater and better corn production."

The resolution was seconded and unanimously adopted. 


\section{ADDRESS.}

By B. F. Harris,

Chairman of the Agricultural Commission of the American Bankers' Association, Champaign, Ill.

A little less than two years ago it was my privilege to address the Pennsylvania Bankers at Bedford Springs, and it is, indeed, a pleasure to be with you again. While there are four states represented at this conference, I presume Pennsylvania predominates.

There has been comparatively little trouble in getting the country bankers to understand the importance of this movement for a better agriculture and rural life, because the country banker is in direct and almost constant touch and contact with the farmers and has become interested in the work.

The city banker has shown some sympathy, not expressed in any concrete way, however, until Mr. Calwell and the Corn Exchange National Bank called this conference.

Some time after I addressed the 1912 Pennsylvania Bankers' Convention on the subject of "The Banker and His Relation to the Public Welfare," I was pleased to see the Logan Trust Company, of this city, exhibit its interest by printing a large edition of that address and spreading it broadcast, with the hope that it might prove of some practical benefit.

Too much cannot be said of President Calwell's effort; because the Corn Exchange National Bank, over which he presides, is the first bank in any large reserve city which has shown any active interest in this movement.

Speaking on behalf of the Agricultural Commission of the American Bankers' Association and the Conference of the Agricultural Committees of the thirty-seven Bankers' State Associations, I want to express their high appreciation of the impetus this conference gives this movement.

At the conference yesterday, a representative of the Girard Trust Company of Philadelphia demonstrated that his company was trying to be a real trustee in spirit and in fact, and more especially as to its agricultural trusteeship. Trying to properly develop their farm properties, trying in their capacity as trustee to build up the farms and rural conditions as well. It is wonderfully encouraging to see such wholesome and helpful work, and I am glad that Mr. Calwell was able to bring out that feature of trust company service in this program. 
The newspapers, of course, are most essential agencies in disseminating information as to the work in which we are engaged, and it is a pleasure to refer to them.

This morning I came into Philadelphia; I picked up a North American and found a two-column editorial devoted to and commending our work and our new magazine-The Banker-Farmer. The newspapers have given space to this conference, not as much as they should have given, but I believe the newspapers were taken unawares, as many of the rest of us were, for it is an unheard-of thing to have a bank, and a big city bank at that, attempt such a conference as that now closing. This conference is of great importance, as you must realize. I have been here three days and I don't know of any meeting, farm, conference or institute, I have attended where the program has been so wide and varied, as well arranged as this, with relation to the question of agriculture and rural life in its varied phases.

After the 1912 meeting of the Pennsylvania Bankers' Association, when its first Committee on Agriculture was appointed, they showed great interest in your State Agricultural College, and tried, as I understand it, to get a much larger appropriation than the $\$ 10,000$ a year appropriated for farm demonstration, and to which Mr. Calwell has referred. As I came down here the other day, I stopped off at State College to see what they were doing, and Dean Watts asked me to speak to the boys in the agricultural college. I found in talking with him that the college in 1910-11 had 437 young men in attendance. In 1912-13, two years later, this number had grown to 2,000. Think of that growth and the promise it offers. A five-fold increase in the last two years. It is indicative of what the bankers and business men may help to accomplish, and the Pennsylvania Bankers' Association has a great field before it.

Thirty-six Bankers' State Associations now have committees on agriculture and education. These committees are meeting in annual conference, having met recently in Kansas City, your State Association being represented by Mr. Stubbs, and Mr. James, whose untimely death we all mourn, was chairman of your Committee on Agriculture, one of the best known men in the American Bankers' Association. He was substantially the author of the new platform and constitution of the American Bankers' Association.

As an outgrowth of this conference of the various state bankers' associations, you have The Banker-Farmer monthly, some few copies of which have been distributed about the room.

The Agricultural Commission of the American Bankers' Association is publishing The Banker-Farmer to review the activities of the banker, and his State Association and Committees, looking toward a better agriculture and rural life, not simply as a matter of information, but with the idea that bankers will read it with the thought in mind, "In what way may I assist and co-operate in this work of agricultural and rural life 
development, and bring into effect in my state and my community the same sort of work."

Furthermore, the conference has developed the fact that one of the most important things a state can possibly do is to make a soil survey of the land and promulgate information as to its agricultural possibilities and requirements, showing what sections of the state are fitted for agriculture and what kind of agriculture, and what sections of the state are not so fitted. Thereby the present and prospective citizens of the state may be informed, intelligently directed, and may not be exploited by the unscrupulous real estate agent or otherwise misled through representations that cannot be fulfilled.

Then as to fertilization. Pennsylvania spends eight or nine millions of dollars in fertilizers annually, and it is the duty of the state, through proper agencies, to inform the people as to proper methods of fertilization, what method they should use and what they should not use. Farmers in many instances pay out large sums of money for types of fertilizer they do not need or could grow or buy cheaper in other forms. In other words, we want a system of fertilization calculated to serve the exact needs of a particular soil, at the least cost to the farmer, and without injury to his land.

Then, one of the next most important things is the farm demonstrator. The agricultural colleges have developed a remarkable store of information which does not reach the farmer, for the colleges are not in close touch with the farmer. There has not, in the past, been money or method of getting to the farmer on the farm. Thus the county agent or farm demonstrator has evolved with the idea that ultimately we will have such a man in every county of every state in this union who will go among the farmers and show them, right on their farms, the newer methods of agriculture and soil conservation.

You have several notable examples of this, notably in County Agent Ross, of Bedford County, who is doing a great work in his section, and Dr. Hurd, of Massachusetts, will tell us in a few moments details of this work in various sections of the country.

And the real achievement uppermost in our minds is improvement of the country schools. We feel that if not the largest measure, then a much larger measure of aid should be given to the country boys and girls, to the elementary schools; to the largest number of boys and girls who are in school for a short time.

We find in many states, in my own for example, 300,000 boys and girls attend the country schools, 90 per cent of them there receiving all the education they ever get, and many of these schools are poor enough at best. We frequently penalize the country children with schools a selfrespecting town would not tolerate.

In Boston we noticed the inscription on the facade of that great public library, "The Commonwealth requires the education of all the people 
as the safeguard of order and liberty." Yet we believe that the emphasis should be laid on efficiency and service for "order and liberty" grow out of efficiency and service.

It seems to me that on the three things: health, trained efficiency and the desire to be of service, hang all the laws of popular education and its regenerative influence on free government.

Then, another one of our planks is that of good roads. We have talked to the farmer about poor roads, but we have not laid stress on the social side; it has been more the matter of getting in and out to market more readily and all that sort of thing. Good roads are one of the greatest necessities of the country today, and they lead in more good directions than we can contemplate. You of Pennsylvania, and also of New Jersey, Delaware and Maryland, are doing each year more than ever along this important line of public improvement, but much more must be done.

We have few good roads in Illinois, and you are undoubtedly ahead of us in that respect.

Rural credits is another phase of the farm situation which the banker is interested in improving, because we are especially concerned in proper and economic and remunerative results on the farm. If the new currency bill is what it ought to be, it is going to make it possible to take care of the short-time credit needs of the farmer.

The other feature that the currency bill can't take up is the matter of mortgage credit. It seems to me that may be best handled through state legislation, because the requirements of the forty-eight states differ radically and then, too, the various states know their own needs better than the Federal Government knows them.

Marketing and distribution is one of the greatest problems, for markketing is just as necessary to production as is harvest.

The country. town must be maintained and made one of the rural centers, for farming is a life as well as an industry, and must be built up upon the social as well as the productive side.

This gives you a brief outline of some of the planks in The BankerFarmer platform, some of those with which we are most concerned. You know the story of the man who walked up to the bank counter and wanted to make a loan. After various propositions had been offered by the would-be borrower, the banker made his answer short by saying, "I can't make the loan; circumstances over which I have no control prevent my making the loan." "But," said the would-be borrower, "what are those circumstances?" and the banker replied, "Your circumstances." [Applause.] That happens very frequently, and we are apt to look at the agricultural proposition in the light that "We are not concerned with the farmers' circumstances."

We must, however, be concerned with his circumstances, and those of every man, woman and child in this country, because we are beginning to remember that the welfare and life of this nation depend on the 
well-being and prosperity of the average man, woman and child in the nation.

Mr. Calwell's splendid opening remarks bore on many of these points which we must lay to heart. I want you to have in mind, in connection with what I am saying on this subject, that I was born and bred both a farmer and a banker, in Illinois, and I have been exposed to both propositions from my earliest days. Earlier, I didn't appreciate the agricultural side as I have later. Now a large part of my sympathy is on the agricultural side. I am still in banking and farming, but above all things I try to bear in mind that man has two great concerns in life, one the conquest of his environment, the other is to express and interpret what life means to him. Most of the bankers have gotten well along in the conquest of their environment, and they, more than many others, have the opportunity and leisure and the wherewithal, and are rapidly and happily beginning, through public welfare work, to express "what life means to them."

In other words, the basis of banking, like the basis of the rest of life, is moral, not financial. We are all beginning to realize we must be progressive in order to be conservative. It has been my privilege to attend many state bankers' conventions, and this spirit undoubtedly prevails and grows amazingly.

The greatest feature of this movement is response, and the prompt response that has come to the call for help toward a better agriculture and rural life.

In the fall of 1914 the Agricultural Committees of the State Associations are to be the guests of the Chicago Clearing House, and you will see bankers there from all sections of the country, discussing the various subjects I have referred to in such a way as to inspire any man and the believers in citizenship.

The banker is misunderstood in a great many instances, yet if time is taken to properly consider his attitude he will usually be found to measure up to all that is for the public welfare.

The bankers in fine spirit are recognizing that the business of banking is not only the business of the banker but is also the public business, and they demonstrated that at the recent currency conference in Chicago.

The bankers for twenty-five years have wanted a new currency system, and have called for it, and when they called for it the people felt it was something the rest of the community didn't want.

As a rule, the bankers fear political control as much as the politicians pretend to fear the bankers in the matter of control of the banking system of the country.

The press of the country and the public of this country should feel, as they really know in their hearts if each individual answers this question honestly, that the banker in his own community is one of the most trusted of men, for the banker knows and feels he must have that community's 
interest at heart and that the prosperity of the community is likewise that of the banker. So it has been an inspiration to me to see the response which has come through the bankers in behalf of this movement.

The Saturday Evening Post some weeks since, referring to "The Banker-Farmer Partnership," said, "Why stop at the farmers?" The Banker-Farmer tried to answer that. I do not believe the bankers of this country intend to stop there. Of course, we know in any movement in this country, whether it be in public or private life, service rendered is simply casting bread upon the waters. There is no doubt when results are brought to pass that Mr. Calwell's efforts to do service in this community will be realized, and you will see the effect of it. [Applause.] In trying to bring out the best there is in the soil and rural life, the banker is bringing out the best in himself. We want to make The Banker-Farmer the Banker-Everybody.

In Illinois we have the reputation of being the greatest agricultural state in the union. I am not going to advertise Illinois, because that is not so. Illinois is not the greatest in actual results, but I have some figures on Pennsylvania Agricultural Statistics which I would like to read to you.

In trying to solve your farming problems, you may find some light in these census figures. While the figures I give you are rather disparaging to Pennsylvania, yet perhaps the best way to get Pennsylvania to take her proper place in the agricultural ranks of the North Central States is to read the comparative figures.

There are, of course, local conditions that affect or in part explain some of these figures, but in general they are as accurate as such broadly gathered statistics may be, and they are at least sufficiently correct to unmistakably show that you are due for a revival.

Of the nine North Atlantic States (Connecticut, Maine, Massachusetts, New Hampshire, New Jersey, New York, Pennsylvania, Rhode Island and Vermont) Pennsylvania has the largest number of farms $(219,295)$; has as much or more improved farm land than any of these states except New York, while four states average larger and four smaller acreage per farm.

While Massachusetts with her average farm of 77.9 acres, 31.5 acres (40 per cent) of which is improved; Pennsylvania's farms average 84.8 acres with 57.8 ( 60 per cent) improved acres.

The value of the land in the average farm in Massachusetts and Pennsylvania is almost the same $-\$ 2859$ and $\$ 2875$ respectively, though Massachusetts' improvements are valued at \$2401 as against \$1873 in Pennsylvania.

Massachusetts, however, leads all these states in the value of all crops and livestock products per improved acre with $\$ 51.42$; while Pennsylvania brings up the rear with $\$ 22.25$ per improved acre.

On improved acre basis, Pennsylvania's crops average $\$ 14.09$; live-stock $\$ 9.09$; while Massachusetts' corresponding figures are $\$ 27.44$ and $\$ 23.98$. 
On the basis of the entire farm, Pennsylvania farms average 4.3 cows each while Vermont averages 8.1, New York 7.

In these nine states Pennsylvania again brings up the rear in the average farm value of dairy products at $\$ 192.22$, while Massachusetts' farms average $\$ 411.40$, Rhode Island $\$ 390.39$, New York $\$ 360.89$.

Pennsylvania barely leads with an average of 4.5 hogs per farm, while, for example, Iowa has 34.8, Florida, 16.2.

All the nine states, except Maine, New Hampshire and Vermont, also lead Pennsylvania in egg and poultry production per farm, for Pennsylvania averages $\$ 117.56$, Massachusetts $\$ 251.43$ and Delaware $\$ 166.81$.

In the total value of crops per farm, Pennsylvania with $\$ 760.35$ is below all except Maine, New Hampshire and Rhode Island, and really below them on basis of cultivated acres.

More livestock and dairying would help Pennsylvania farm incomes and soil.

We are just beginning to practice in Illinois what Abraham Lincoln suggested fifty years ago. Abraham Lincoln put it this way: "Unquestionably it requires more labor to produce fifty bushels of wheat from one acre than ten bushels of wheat from one acre; but does it require more labor to produce fifty bushels from one acre than from five?" In other words, we want to raise our crops on fewer acres and devote the balance to livestock, because in so doing we are helping to maintain the farm by feeding the livestock and should thereby get two profits for our crops.

The movement of the banker in behalf of agriculture is not a movement simply for productivity, but also to up-build the farm-to make life on the farm worth living, and unless 'we make that life and all its conditions what it should be, we won't win on the productive side. We must make the farm more likable. There are two kinds of rural decay. We have it in various sections of the country. One is the kind that takes place under the ground that enriches the soil, and the other takes place on top of the land and impoverishes the people. The latter is the thing the bankers' committees are fighting against. We feel that the care of the soil and the care of its caretakers is the most important problem we face.

You have been very patient, and I wish to thank you and congratulate Mr. Calwell again on this auspicious event.

Mr. Calwell: We are in one of the richest agricultural sections of the United States, I understand. The last census gives Lancaster County as the richest county in the United States. In money value of farms, Chester County was No. 3, and Bucks County was No. 5. Here we are, right around us. [Applause.]

When you go over to Jersey, and down to Delaware and Maryland, all I know is the "Eastern Shore" [applause]; the ground is the best you 
can get for agricultural purposes anywhere in the United States. And it is not being developed. A banker told me (he is not here today) that right in this city he knew of ground along the creek or river that was twenty feet deep in red soil and nobody using it. He said you could get that ground for $\$ 5.00$ to $\$ 10.00$ per acre, and the richest kind of soil. Why doesn't New Jersey establish an experimental station on that ground? I think it would tone up some of these sections there in South Jersey.

We have found in what we have done in this corn conference that it is hard to get in touch with the farmer. He doesn't come to these meetings, only half of them, and he doesn't want to bother with reading about economics of the farm, so the best way we have heard of here as to reaching him is by direct work. The ablest man I know of, one of the very best in the country, is a man whom we have with us here today, Dr. William D. Hurd, of the Massachusetts Agricultural College, Amherst, Massachusetts. He has gone into this extension work right out on the farms and taught the people how to improve their farms and to encourage them in this connection.

Senator Gore was in attendance at this conference a few days ago. He said he had just introduced a bill in Congress which would authorize the establishing of a farm bureau in every county throughout the State of Pennsylvania. That bill is going to come before Congress. It has already been presented, and I think Pennsylvania ought to be very proud, and the Pennsylvania bankers, and the New Jersey bankers, the Delaware bankers and Maryland bankers should take some interest in the bill, because that is the best way of helping agriculture, by getting some one who can go out on the farm and teach the farmer right on his own ground what he ought to do.

I take great pleasure in introducing Dr. William D. Hurd, who will talk to us on extension work. 


\title{
THE STATE AND THE FARMER: TEACHING AGRICULTURE TO THE PEOPLE OF A STATE.
}

\author{
Dr. Willitam D. Hurd, \\ Director of the Extension Service, Massachusetts Agricultural College, \\ Amherst, Mass.
}

I have come to speak with some hesitation. I don't want anyone to get.the idea here that I have come to flaunt the work we are doing in Massachusetts, because I realize in the four states that are represented here today you have agricultural colleges which I presume are doing work of a similar character.

I thought you folks would look on agriculture in our state as a joke, but after Mr. Harris's figures which he gave us I think I need not make any further reference to his remarks on agriculture on that stormy and rock-bound coast.

When the Honorable Justin S. Morrill introduced into Congress, and Mr. Lincoln in 1862 signed the bill bearing the former's name: "giving land to support and maintain in each state at least one college, where the leading object should be, without excluding the classics and other scientific branches, . . . to teach such branches of learning as are related to agriculture and the mechanic arts . . . in order to promote the liberal and practical education of the industrial classes in the several pursuits and professions of life" there was no doubt in the minds of these men that these colleges should make themselves useful to all the people who supported them as well as to the few hundred students fortunate enough to be able to receive their benefits within the walls of the college buildings and campus limits.

For twenty-five or thirty years these colleges confined their efforts largely to two lines-the teaching of college students, and research and experimental work provided for by subsequent acts of Congress-both lines absolutely necessary to future agricultural progress.

But as time went on, economic conditions changed in this country. A popular clamor was raised, demanding that the knowledge possessed by the scientists in our colleges and the results of the research work of our experiment stations should be carried out by practical demonstrations to the man on the land. Today the great problem in our agricultural education is not the teaching of college students, nor the conducting of the research work in our scientific laboratories, but rather the devising of sane, dignified and systematic methods of extension teaching whereby 
the best scientific knowledge and the most improved farm practice may be carried out to the American farmer in things that he can see and methods that he can use.

The agricultural colleges, then, are fulfilling the ideals of their founders, Mr. Morrill and Mr. Lincoln, when they teach, when they experiment, and when they help all the people who support them through the taxes which they pay.

I have been asked to tell you what our college is doing and the contribution it is making toward building up the agriculture and rural life of our commonwealth. In doing this I make no apology for the frequent reference to our work. I recognize fully that several other institutions are doing a similar and even greater work than are we.

For lack of time I say nothing about our academic and research work, but we must recognize clearly that the latter is the fountain head from which we secure all facts to be used later in our teaching and extension work.

I would say in passing that the organization of our college is as follows:

1. Academic. Four years. Graduate.

2. Experiment Station.

3. Extension Service. All except above mentioned.

Only the briefest mention of our different activities is possible.

Like many other colleges, we offer short winter courses for mature men and women who can come to the college only for a short time. Hundreds come each year to our "Annual Farmers' Week," the programme of which is full to overflowing with the newest ideas on agriculture and country life. We teach apple packing and grading in a special course on this subject. We try to instruct special groups like the tree wardens of the state, fertilizer agents, seed dealers, milk inspectors, and others by offering courses especially adapted to their needs.

We hold annually a summer school, not so much to teach practical agriculture as to instruct and inspire rural clergymen, librarians, grange officers, county Y. M. C. A. workers, boards of health, town officials, and others who should be the leaders in their several communities, with the new country life movement in order that they may return to their communities with the knowledge of how a better community life and finer public spirit may be brought about.

We bring boys from the smaller towns to the college during the summer to an agricultural camp and teach them agriculture, clean sportsmanship, recreation, photography, clean living and other interesting things. By this we turn their attention to their own towns and create in them a genuine sympathy for these things. We acknowledge, of course, that many country boys should turn their attention cityward. We hope, however, to help stop the general drift in this direction.

People from all walks of life gather at our institution each summer in conference to discuss problems of community building and planning. 
All over our own and other states we find inspired leaders carrying out the suggestions received at our conferences in their own towns.

We are not unmindful of the foreigner within our gates. We hold each year, both at the college and in different sections of our state, special days for the Poles, Italians, Jews and Portuguese who are colonizing certain sections. We teach them English, civics, agriculture, and strive to plant in them high ideals of what American citizenship should be.

We encourage all sorts of agricultural societies and organizations to meet at the college and arrange helpful and entertaining programmes for them.

For those who cannot come to the college at all, sixteen correspondence courses in as many agricultural subjects are offered at small cost.

The members of our faculty gave during the past year more than 500 free lectures and practical demonstrations. These were given before men's and women's clubs, granges, church societies, Y. M. C. A.'s, boards of trade and other organizations. Courses having as many as twenty-six lectures were given in some communities.

When it is impossible for an instructor to go for one of these meetings, we send a written lecture and a set of lantern slides.

In such communities as may request and where proper interest is shown, we hold extension schools of agriculture and home-making lasting five days each. Soil fertility, dairying, fruit growing, poultry raising, and home economics subjects are taken up. Ten exercises in each subject allows of quite thorough instruction being given. It is really a college short course transferred to communities all over the state.

We do not limit these schools to the productive side alone. Next week an extension school, devoted to problems of community development, is to be held in one of our small towns. Such subjects as the following are included in the instruction given:

Town planning for rural Massachusetts.

Methods of managing town improvement work.

Improvement of home grounds.

Co-operative buying and selling.

A new movement for local taxation.

Better methods of marketing.

Law enforcement.

New methods in education.

Labor saving appliances for the home.

Relation of right nutrition to general welfare.

Making up a community programme, and others.

We co-operate with steam railroads and trolley lines in the operation of so-called "Better Farming Trains" and believe these to be an efficient means of introducing farmers to adopt more up-to-date methods. We have pretty well-defined plans for fitting up cars permanently, lengthen- 
ing the time of stop to a half day or day, instead of an hour or two, and going out on these trips for a month or more at a time.

We find that many managers of agricultural fairs are anxious to abandon the questionable midway and "fakirs" row" to a large degree and are desirous of making these exhibitions more educational in their nature. We have prepared extensive educational exhibits and supplement these by five or six short practical talks and demonstrations each day. Our men also act as judges at these fairs, usually giving a judging demonstration in connection with the work. That this work is appreciated is shown by the eagerness with which our exhibits are sought by fair managers and the ever increasing attendance at the educational features.

Massachusetts is a natural fruit state but our opportunities in this direction have long been neglected. We are trying to build up the production of better fruit by planting demonstration orchards in all good fruit sections. These are handled under the direction of our trained men. Spraying, pruning, grading and packing meetings, to which the whole neighborhood is invited, are held annually. Thus the orchard, being a practical demonstration of proper practices, becomes the center for the dissemination of information on this subject for that entire region. There are, of course, other activities, such as lectures, apple campaigns, fruit shows, demonstrations, advice, etc., also carried on.

We are trying to build up the dairy industry of the state by the organization of dairy improvement, and community breeders' associations, by the conducting of milk campaigns in which producers, milk handlers, peddlers and consumers all come in for a share of the instruction. The opportunity of reaching large numbers through the public schools is not neglected. Boys' stock judging contest, milk shows, substantial prizes for clean barns, healthy animals, and the elimination of flies are all a part of our programme.

Two hundred and forty-eight graduates and former students of our college have banded themselves together into an agricultural improvement association. They pledge themselves to develop higher producing strains of crops and animals and to work for a better rural life. High grade strains of corn and potatoes are being developed for seed purposes; pure bred animals are being more generally introduced.

We lack in our state reliable information about our agricultural resources, present farm practices, costs, profits, the conditions of our schools, our social life, etc. To secure this we plan extensive comprehensive surveys which we hope will in time cover the entire state. Using the data thus secured we feel that we can make pretty definite recommendations as to what changes are needed.

Efficiency methods in business management and even in the administration of city governments have been generally accepted as desirable. Rural communities are still plodding along in well-beaten paths of past years. Through our community service work towns are advised, after a 
careful examination has been made by our experts, as to what their needs are. The people themselves usually set about by means of committees to study the agricultural, educational, civic, transportation, recreative, and religious needs of their own communities. I have time to give you the results in only one community where such a movement has taken place. The farmers have co-operated in buying fertilizers, feed stuffs, spraying materials, and in selling their fruit, thus saving money at both ends of the transaction. Appropriations have been increased for roads. Experts have been called in to advise them as to how the schools may be improved, landscape architects have advised them on town beautification, and two struggling churches have decided to unite into one strong, useful body. Petty jealousies have been wiped out, and there is a "get-together" spirit in that community which has not been known there for generations.

We teach agriculture to more than 20,000 boys and girls through corn, potato, tomato canning and poultry clubs, each year. Trips to Washington, Boston, and the college furnish ample reward to the state winners. Girls performing household duties are in the future to have the same opportunities in this competition as their brothers who are in the crop and poultry contests. This club work has well been called "the kindergarten of agriculture." Surely it will have a greater tendency to interest boys and girls in plants, animals and things agricultural than any other movement that has yet been started.

In co-operation with the Bureau of Plant Industry, United States Department of Agriculture, we make farm management field studies and investigations. Farm records, showing profitable and unprofitable enterprises, labor income, etc., are taken; accounting systems are introduced; farms are reorganized; advice is given as to equipment, buildings, cropping systems, rotations, etc.

We have a demonstration auto truck equipped with spraying apparatus, pruning tools, dairy appliances, stereopticon and slides, books, pamphlets and other appliances, in charge of a competent demonstrator. This man goes from town to town meeting small groups of farmers for conferences, and then visiting individual farms to demonstrate any of the things on which information is desired. This is the most effective means of getting close to the individual farmer that we have yet tried.

In all of this practical instruction of the farmer we are not overlooking the farmer's wife, his daughter, or the problems of the home. The balanced ration for the family is now to receive as much attention as the balanced ration for the cow. Our instructors in home economics and domestic science work through the granges, women's clubs, extension schools, teachers' associations, and other organizations for women, giving instruction in problems of food, sanitation, labor saving equipment, home beautification, textiles, clothing, etc.

One of our recent developments is the taking on of a man trained in landscape architecture and thoroughly imbued with the civic improve- 
ment spirit. He goes to towns where he is invited and assists in town planning projects, the beautification of the town commons, the planning of school and church grounds, the care of cemeteries, home improvement, the acquiring of land for play grounds, and other things of this nature.

We assist the smaller libraries of our state to develop the habit of reading agricultural literature by loaning them for certain periods of time traveling libraries of from ten to forty of the latest and best books on rural life subjects.

We believe thoroughly in the value of demonstration plots placed out on farms operated by the owners all over the state. Every year we have a large number of these showing the results to be gained from the proper use of fertilizers, high grade seeds, rotations, pasture renovation, etc. We are also placing alfalfa plots out in a similar way. The best demonstration farm, in our judgment, is one operated by a man who can show a profit from his labor and management.

We are co-operating with boards of trade and other organizations in the placing and maintaining of county agricultural advisers or representatives. We believe that these trained men, confining their work to a relatively small area, becoming personally and intimately acquainted with the farmers of their territory, and demonstrating to them better farm practices, advising them in problems of farm management and marketing, and bringing into each county for the building up of the agriculture and rural life of that county all the help that can be obtained from the state college, the other agencies created in the state for purposes of furthering agricultural growth, and the United States Department of Agriculture, are to be mighty factors in accomplishing the exceedingly difficult task of reaching the last farmer on the last farm in any region.

If you do not think that there is a live interest in this county work movement in our state, I wish you might have been with me last night at a dinner of three hundred of Springfield's largest and most influential business men. They sat for nearly six hours and talked over in a most interesting and intimate sort of way the things they might do for developing the rural life of Hampden County.

We attempt to instruct the poultrymen, the beekeepers, the floriculturists, the market gardeners of our state in the same manner as we do the dairymen, the orchardists, or the general farmers.

We publish popular, yet reliable, leaflets and bulletins in large numbers.

Within a month we shall have a man in the field helping to organize farmers' co-operative organizations for purchase and sale, giving assistance to farmers in marketing and along rural credit lines.

We help thousands by personal conferences, farm visits, and letters each year. In fact our statistics show that we definitely and directly reached more than 300,000 people in our state during the past year, and of course there is no way of estimating those who were indirectly touched or influenced. 
I want to impress you with this fact, that we are not one-sided in our work, but touch the production side of farming, the problems of marketing and transportation, the community problems, and the home problems alike.

You may ask, how are we able to do this?

We do it by the employment of persons who by temperament, scientific training, practical experience, and personality are able to instruct the farmer, the business man, and the professional man in our state. These extension instructors work in close touch with, and in perfect harmony with the teachers of our college and the research men of our experiment station. At present there are twenty giving full time and three or four part time in the work. In fact, the Extension Service of our institution is the whole college at work throughout the state.

We do not accomplish this work by creating new organizations; we work through granges, boards of trade, men's and women's clubs, with the State Boards of Agriculture, Education and Health, and other statewide agencies, in fact with any organizations that will join with us unselfishly in building up the agriculture and rural life of our commonwealth. By this means all organizations are enlisted in a state-wide movement and campaign for rural progress. We have, in fact, a federation of thirty of the agricultural organizations in our state getting behind all desirable movements at the present time, and "squelching" others not so desirable. This getting together is absolutely necessary, else waste of energy, money, and misunderstanding, jealousies, cross-purposes, and lack of harmony will evidently result. We do all this, too, without sacrificing any educational ideals, or interference with the academic work of our institution.

I realize perhaps more than you do that I have given a very feeble and inadequate description of our work, but it would have taken hours to tell you all. This whole movement with us is the social service spirit applied to rural work.

You may raise this question: Why should all of this effort be made in behalf of agriculture at the present time? There are many good reasons. It is no longer a pretty saying - a mere platitude - that agriculture is the foundation of our national prosperity. The fact is being driven home to us on every side by the acuteness of economic conditions.

We now consume 91 per cent of our wheat.

We now consume 98 per cent of our corn.

The decline in our exports of cattle in the last five years has been 75 per cent.

The increase in importation of cattle has been 2000 per cent in six years.

Our average yield of wheat per acre is 14 bushels; the farm average of western Europe is 32 bushels. This comparison is not at all to our credit.

This nation is facing the question of what we are going to eat in 1963, when our population reaches $200,000,000$ as it undoubtedly will. 
City and country dwellers alike have come to a keen realization that the agricultural problem is neither sectional nor territorial in its importance. We in Massachusetts grow neither beef, wool, wheat, nor cotton in any quantity and yet our very existence, in fact our continued prosperity, depends almost entirely on knowing that some one, somewhere, is interested in the production of these great staple products on which we are so dependent.

James J. Hill, among other great leaders in industrial development, has repeatedly called attention to the fact that the products of the sea, the forest and the mines are fast being exhausted, and in a virile convincing way refers to the soil as the one permanent resource, and he raises the question as to what we are going to do with it in the future.

Despite all the teachings of our colleges, the work of our experiment stations, the publicity and instruction given through the agricultural press, and the great work of the United States Department of Agriculture, yet we face the fact today that the yield per acre of all of our great staple crops has not increased materially during the last forty years.

So I think I was justified in the outset when I contended that the greatest problem in agricultural education and in American agriculture today is the instruction of the farmer who is now living on the land. This must be by a positive, direct, speedy process. Information must be carried to him by persons especially fitted for the task and by the best demonstration methods.

The principal agency from which all this work should radiate in a state is the state college of agriculture. Land, buildings, equipment, men, laboratories, etc., have been placed there at great expense. These institutions should be public service institutions. Their worth and usefulness to a pretty large degree should be measured by the service they render to the people who foster and support them. We have tried to make our college such a public service institution.

No man in a community is more interested in general prosperity than a banker. When farmers are not prosperous then bankers cannot be. When a farmer is charged high rates of interest or is not given fair 'credit accommodations he is made poorer. The farmer's interest is the banker's interest.

Bankers may well interest themselves in, and become familiar with the soil, crops, prevailing farm practices, and agricultural resources of the region in which they live. Farmers may well consult bankers on questions of investments, exchange, markets, etc. This interchange of information will be more than mutually agreeable. Bankers must surely have the confidence of farmers.

There is much "frenzied" talk about farm finance at present. Many schemes, most of which are probably unworkable, are in the air. Personally, I do not believe we need a system of credit for our American farmers based on that necessary for the peasant farmers of Europe. It's 
a safe proposition for you to make long term loans to farmers on the amortization plan, as suggested by Mr. Harris of Champaign, Ill., Mr. Woodruff of Joliet, Ill., and others, and this would help the farmers immensely. I do not think that you as bankers should be asked to loan money to farmers on any different basis than to other business men. Give him the same chance as you do the man on the street-he hasn't had this up to the present time. The shiftless farmer should be treated in the same way by you as a business man in the town who in your estimation is not making good. You ought to remember, however, that some one must carry the farmer over from seed time to harvest, and that the crying need on most farms is just a few hundred dollars more working capital each year.

The matter of proper farmers' organizations to secure credit can be made a simple one. Ten of fifteen farmers of a community might join forces, declare their total assets, incorporate with a limited capital stock, and mutually agree to back each individual of the group for a loan up to a certain limit. This would be safe for you. Could anything be easier for them?

Individual bankers and the banking associations of Wisconsin, Minnesota, Illinois and other middle western states are behind the farmers of that region. They support contests for boys; they are helping to secure larger appropriations for schools and colleges; they are contributing toward the support of county agents; they help secure legislation for better roads; and in many other ways.

Some one at the recent Bankers' Association meeting in Boston said that the products of the American farms amounted to ten billions of dollars, and that this was an amount greater than had been secured from the gold mines of the world in the last twenty-five years. So you see that in assuming this interest you are dealing with a subject of no mean proportions.

You men here in this great commercial and industrial metropolis, representing the banking interests of the state, can do nothing better for yourselves, your families or your nation than to get behind this movement here in the East and lend your thought, influence and best efforts to the support of the agencies which have for their aim the building up of our eastern agricultural and rural life.

Mr. Calwell: It has been the custom at these meetings to have discussions. Dr. Hurd's paper emphasizes many things on the subject he has addressed us, as to the different lines of work for the farmer, and for college men, and if there are any questions to be asked Dr. Hurd will no doubt gladly answer them.

I would like to ask Dr. Hurd if he knows how much is appropriated by the State of Massachusetts to his college for extension work.

Dr. William D. HuRd: Our extension work has been organized four years. The first year's appropriation was $\$ 10,000$, the second year 
$\$ 15,000$, the next year $\$ 50,000$, and now we have $\$ 50,000$ appropriated by the state for this work.

Mr. Calwell: Pennsylvania has $\$ 10,000$ appropriated for this same work. The paper Dr. Hurd has just read to us is going to be published, and there is enough in that paper to keep us bankers busy for the next five or ten years.

The raising of crops is not the only thing, the increase of crops is not the only thing. They must be marketed.

One of the greatest successes of the country is the forming of these farmers' exchanges in different sections, to collect goods and ship them into the stations in carload lots.

One of the most successful of these exchanges has been formed down in Virginia, and we have with us Mr. N. P. Wescott of the Eastern Shore of Virginia Produce Exchange. Mr. Wescott is very well known throughout agricultural sections as one of the leaders in this movement.

Mr. Wescott will now address you. 


\section{THE WORK OF A PRODUCE EXCHANGE.}

\section{BY N. P. WescotT,}

Eastern Shore of Virginia Produce Exchange, Onley, Va.

Farming, today and in this country, is fundamentally a business-a method of making a living. There are persons who live on farms and who, more or less by proxy, conduct farm enterprises, by reason of a purely intellectual interest in the processes involved, or of a real or imagined taste for the much-advertised delights of country life, or a pride of proprietorship, or from other motives unmixed with economic necessity. But these fortunate individuals are not farmers; they are only "gentlemen-farmers." The true farmer farms not for love but money - and gets his poetry elsewhere. Whether he stays and works the farm of his fathers or whether he abandons the rear end of the plow for the front deck of a trolley car, it's because he can-or thinks he can-earn more that way; and whether he sows wheat, plants cotton or beds sweet potatoes, the ultimate crop he hopes to harvest is one of dollars and cents, and the exact measure of his success is the amount of his net profits at the end of the year. Moreover, after a boyhood on the farm and an experience of four years in working for some three thousand farmers, I shamelessly make the sordid assertion that profitable farming is profitable farming, and-Horace's celebrated catalogue of delights to the contrary notwithstanding - that it is the only pleasant kind.

From this it follows that the basic factor in the problem of the farmer's welfare is the economic factor, and that in any thoroughgoing effort to improve the condition and promote the happiness of the farmer the question of profitableness demands first consideration and offers logically the best ground of attack. In attacking this problem, great stress has been laid upon the obvious and visible fault of unscientific methods of production; everywhere we now see experts at work teaching the farmer how to make two blades of grass grow where one grew before. But there is a more insidious fault-one less apparent but equally destructive of the farmer's fair measure of prosperity - which has been, I believe, not fully appreciated or even clearly perceived-and certainly not sufficiently attended to. Of what use to the farmer is the product in beef or grain of the two blades of grass if it have not a ready and profitable market? As a matter of actual experience, the farmer with a doubled output, exceeding the normal demand or overflowing the usual channels of distribution, frequently finds that the very bounteousness of his harvest spells disaster; for the tolls levied by the various agencies of distribution are, in general, fixed charges, at so much per unit, and with even a slight de- 
cline in gross price consequent upon increased production the farmer's margin of profit may entirely vanish. In short, for present-day agriculture, the problems of distribution are just as vital as those of production; if the farmer would succeed, efficient salesmanship is just as essential as the maintenance of soil fertility. Yet the farmer, alone among modern producers, is prone to ignore this matter of selling; and in this age of highly specialized and elaborate salesmanship in all other industries and of increasingly scientific production in his own, we still find him in many communities pouring out his goods blindly into the hands of the commission merchant or bargaining them off at random to some local speculator in the same primitive manner that has come down to him from the days when Joseph and his brethren bartered the surplus products of their crude husbandry for the cloths and spices of the Egyptians.

How then are these forces of aggressive salesmanship, based upon a searching and enlightened knowledge of national market conditions, to be made a part of the enterprise of the farmer? Individually he lacks the time, the capital, the commercial experience, and in general the business capacity necessary to provide them; and even were these requisites present, he would be helpless acting alone among a multitude of fellow-producers whose disposal of their products must restrict within narrow limits the market value of his own. Obviously, then, the true solution lies in cooperation -in the union in this matter of marketing of a great number of small producers whose combined output will entitle them to take rank with modern business enterprises in other fields of industry and whose united strength will enable them to provide at a cost which falls lightly upon the individual the necessary elements of expert salesmanship, capable business management, constant market information, and vigorous cultivation of the available selling field. To the adoption of that plan there has been one great obstacle: the stiff-necked individualism of the American farmer. He doesn't take kindly to the restraints and sacrifices of co-operation. There is too much of Robinson Crusoe in his daily life. Having been always captain of a very small enterprise, he has missed the training of a worker in the ranks of one of the more complex industries; and he chafes under the discipline which is indispensable to all co-operative effort. Indeed, so strong is this original disinclination to pull together with his fellows that ninety-five per cent of all efforts at co-operation among farmers in this country are said to have failed. Yet this principle of co-operative marketing is indisputably sound. The whole tendency of present-day industry is in that direction; and, aside from all theory, the remarkable success of certain farmers' co-operative selling associations that have weathered the early storms and grown into a vigor that gives assurance of stability - and no less, perhaps, the great number of new communities that are now hastening to take them as models-demonstrate beyond question the entire applicability and extreme value of the co-operative principle in the marketing of farm products. 
Of these farmers' associations that have proved their worth by surviving, one of the earliest, and I believe one of the most strikingly successful, is the Eastern Shore of Virginia Produce Exchange; and since the methods by which it has revolutionized the farming industry of the section it occupies are capable of very general application, with equal benefits, in other communities, a brief account of these methods and of the nature and present scope of the Exchange's activities will, I hope, be of interest to this conference.

The Exchange claims as its territory the two counties of Virginia lying between Chesapeake Bay and the Atlantic Ocean, a thickly settled, intensely cultivated peninsula, devoted entirely to truck-farming and mainly to the production of Irish and sweet potatoes, though strawberries, cabbage and onions are also important crops. It now markets the products of some three thousand farmers, comprising about two-thirds of the entire output of the peninsula; and since it is an exasperating incident of this plan of co-operative marketing that even those who actively oppose the association will still benefit by whatever improvement in general market conditions its work may bring about, the Exchange also stands as the chief bulwark against market disaster for the constantly dwindling proportion of Eastern Shore farmers who, for one reason or another, still refuse it their support-as indeed most of them will freely admit. During this, its fourteenth year, the Exchange has marketed over eight thousand caroads of Irish, and over four thousand carloads of sweet potatoes, with enough of its other products to make a total of some thirteen thousand carloads, or about two and a half million barrels, of food products. These goods it has sold to a customer list of more than a thousand wholesale produce dealers in about four hundred different cities and towns of fortyone different states and Canadian provinces. And for these goods it has obtained, and paid over to its members, a total of, in round numbers, four and a half million dollars. During the fourteen years covered by its activities, the peninsula's total annual production of farm products has trebled in volume, farm land values have risen from thirty-five or fifty to from one to two hundred dollars an acre, and there has been an advance which baffles estimate in the general prosperity and material standards of living of the people - and all this in one of the first settled parts of the oldest state in the Union, without any fresh influx of population, without the development of any new industries or transportation facilities, without even any very radical changes in methods of farming, but merely under the gentle stimulus of the nation's generally advancing prosperity and in consequence of the, substitution fourteen years ago of a rational system of marketing in place of the old haphazard plan of consigning to commission merchants or selling at random to speculative buyers. Moreover, although it is impossible to eliminate all risk-although the farmer must look forward to fat years alternating with lean and there must perhaps always occur, as during the last half of the sweet potato season just 
closing, occasional periods of adverse conditions beyond any local control, when farm products cannot be sold at prices which include any element of profit for the farmer, yet there has never been any return in the fourteen years of the association's activity, to the general condition of "hard times" which had become chronic before that period; and it is a mild statement of the facts to say that the Exchange has put the agriculture of the peninsula upon a basis of substantial and assured prosperity.

For an undertaking of this sort, some degree of organization is of course necessary. Let us look first at what might be called the internal structure of the association.

The Exchange is a corporation, regularly chartered under the laws of Virginia. Its membership, by which term I mean to include the entire body of persons entitled to have their products sold by it, comprises, first, all shareholders; second, all tenants of stockholders who at any time may register a desire to become regular Exchange shippers and thereafter loyally carry out that intention; and third, holders of "certificates of shipping privilege," which are purchasable for the nominal sum of one dollar, exacted merely as an evidence of good faith, and which are nontransferable and become void immediately the holder ceases to market his goods exclusively through the association. The entire membership and territory of the Exchange are divided into thirty-six "local divisions," each centering around one or more of its forty-five shipping points. Each local division, acting separately and by a vote of stockholders only, elects annually a "general director;" and the board of thirty-six division representatives thus selected, meeting about monthly, and when occasion arises at briefer intervals, upon call of the president, exercises a general supervision over the current activities of the Exchange. At the close of each year, a general stockholders' meeting is held, at which the entire year's work is reviewed, possible radical changes of policy are proposed and acted upon, and the general officers of the association are elected for the following year. Of these, the general manager and the secretarytreasurer, in charge respectively of the sales and financial departments, of course devote their entire time and energies to the service of the Exchange. With the advice in matters of critical importance of the president, and with the co-operation in their respective fields of the general inspector and the general counsel, they direct and supervise the work of the central office force, of the eighty or ninety local agents and inspectors and of the force of traveling salesmen, act for the association in all important negotiations incident to its business, and, in short, direct and control the regular daily work of the Exchange.

Since the central and essential one of the Exchange's various activities is the selling of produce, a true concept of its workings can perhaps best be had by glancing briefly at the machinery and actual process of its selling. First, it must be noted that the products it handles are all perishable and subject to sudden and wide variations in market value. 
This necessitates quick action. All sales are therefore made by wire, quotations being issued for acceptance on day of date only and each day constituting a separate selling campaign. The Postal and the Western Union Telegraph Company each maintains an office, used exclusively for Exchange business, on the upper floor of the association's general office building. Incidentally it may be mentioned, as affording some idea of the volume of this telegraphic correspondence, that in spite of the constant use of a comprehensive private code-book, of which a copy is placed in the hands of every customer and through which some three thousand of the phrases and sentences in most frequent use may be expressed by single words, the association's expenditures this year for telegrams will exceed twenty thousand dollars. From a telephone switchboard in the general office, centrally located at the village of Onley, five private trunk lines radiate to all parts of the peninsula, giving constant communication with the local agency at each of the forty-five loading points. Early in the morning of the typical day in the selling season, in the large office room where the general manager and his four immediate assistants are gathered to begin the day's work, reports are received by 'phone from each local agency of its prospective loading for the day-the number of cars and the quality and grade of each. In the meanwhile, information is being received by telegraph from connections of the Exchange in the big eastern markets of the exact state of those markets. From the association's representatives in all the other important market centers of the country, constant telegraphic information is also available as to local conditions and prices; and by friendly associations or dealers in other producing sections, we are also kept informed as to the loading and movement of the commodity in question in those sections. Being thus in possession of rather complete information covering the two essential factors of supply and demand, the general manager is able, with something at least akin to scientific accuracy, to determine the potential market value of his goods; and by eight or nine o'clock a range of prices is determined upon and the day's selling campaign is begun with a fusillade of telegraphic quotations, reinforced with whatever selling arguments the occasion may offer, to the Exchange's customers and brokers all over the country and to its outside salesmen stationed upon the various large markets: a fusillade, of course, to be met and followed throughout the entire course of the day by acceptances and counter-offers, confirmations, refusals and all the other incidents of wholesale selling, with the ultimate and everpresent purpose on the part of the Exchange of selling out so nearly as possible the entire day's loading at the best range of prices obtainable under the given set of general market conditions that may then happen to prevail. As fast as orders are booked, particular cars are appropriated to them, with the double purpose in view of moving about an equal proportion of every station's goods and of supplying each customer with the grade of stock his trade demands; and shipping directions are given by 
'phone to the local agents. In the evening, the day's sales-bulletin is completed bafore being passed on to the accounting department by "pooling the prices"-a process of averaging by which each grower will be paid, not necessarily the exact price received for his particular lot of goods, but the average price-received for all goods of the same grade and value with his on the day in question; and as rapidly as the necessary bookkeeping work can be carried through, payment for each day's sales is rushed forward to the local agents, to whom the growers go for settlement. Each agent is of course required to keep an account with every shipper and to make payments exclusively by check; and at the end of the shipping season all agents must turn in their checks, books and records for audit by the bookkeeping force at the general office. All risks of collection are assumed by the association; and all expenses of the business are met by a commission of five per cent on the gross sales, which is of course deducted when the original returns are made.

In carrying out its appointed mission, the Exchange has consistently adhered to certain well-defined working principles, by which its general course of action has been determined and upon which, I believe, its success broadly rests. These demand specific mention, both as being necessary to an appreciative understanding of the work of this association and because they are broadly applicable, with equal advantage, to similar efforts in a great number of other communities.

First, with reference to what may be termed the "home policy" of the Exchange: All such movements are necessarily militant; to understand the workings of any such co-operative association, it must be borne constantly in mind that every minute of its life is a fight-a struggle first for existence and afterward (if there be any "afterward") for an increasing measure of supremacy. For the success of any such movement means loss, or unwelcome change, of occupation for the local exponents of previously existing agencies of distribution which it is the very purpose of the association to supplant. To assume that we have a vested right in whatever benefits we have once uninterruptedly enjoyed, regardless of the original basis of such enjoyment, seems to be a universal fallacy of human nature; and these men, speculative buyers perhaps or solicitors for commission houses, will very quickly be found fighting the new movement in a spirit of personal resentment born of a misguided sense of personal injury and with all the vigor of the instinct of self-preservation. Each of these men of course has some personal following among the farmers; and each can devise a hundred ways to estrange supporters from and incite antagonism to the association. The leaders, therefore, in the cooperative movement must be propagandists-preachers of a new doctrina of solidarity and vigorous advocates of an occasional surrender of immediate and temporary self-interest for the general and permanent good; and throughout the career of such an association, parallel with its external activities as a business concern, there must be kept up in some form this 
constant internal campaign of stimulating loyalty within the ranks and of gaining new recruits. With the Eastern Shore of Virginia Exchange, this fight has been fierce and incessant from the start, and marked by a degree of enthusiastic loyalty on the part of the association's supporters and of bitter antagonism on the part of its leading enemies for which a parallel can hardly be found in politics, or elsewhere than in war. From the beginning it was realized that every Eastern Shore farmer who was not for and with the Exchange was against it - that every man who furnished potatoes to the local dealers whose operations had for years proved disastrous to the country's prosperity and who were now actively seeking to destroy the association, was giving not only "aid and comfort" but in a very real sense ammunition to the enemy. And from the very start the Exchange has insisted as the cardinal and almost only obligation of membership, upon the constant and undivided loyalty of every membər. The very minute an Exchange man yields to the blandishments of the local buyer or to the attraction of an artificial price set slightly in advance of the fair market value of his goods for advertising purposes and in order to make a break in the ranks, the moment he sells a barrel outside the Exchange, he forfeits all rights of Exchange membership and unless reinstated by special resolution of the boald of directors can make no further shipments through the association for the entire remainder of the year. And although occasional more or less valid grounds of dissatisfaction with the Exchange are bound to arise, and the local buyers are always on the alert to pick off stragglers, the total number of desertions has been, on the whole, surprisingly few.

Again, the Exchange differs radically from the ordinary corporation in that its purpose is not the making of profits for its stockholders. Its entire capital stock, in fact, is only forty-two thousand dollars, divided into shares of a par value of only five dollars, which it has been the constant and reasonably successful aim of the directors to keep widely distributed in small holdings. In addition, a surplus fund of about a hundred and ten thousand dollars has been gradually accumulated from the profits of the business; and it is now a regular provision of the by-laws that at the end of each year, after payment of a dividend not to exceed ten per cent, whatever net profits may remain shall be divided in half, one half being added to the surplus in order that the association's fixed resources may keep pace with the constant growth of its business and the other half being distributed back among all the loyal shippers of the Exchange, whether stockholders, tenants of stockholders or holders of shipping privileges merely, in proportion to their respective contributions of produce. 'At the close of the present season, barring any unexpected large loss not now apparent, about fifty thousand dollars remains to be so divided.

And now with respect to the external activities of the Exchange, in pursuit of its original and proper purpose of marketing the products of its members: First and foremost, it aims at enlightened and aggressive 
salesmanship. It gets out for business. It goes to the buyer, urges upon him the merits of what it has to sell, and assures to the farmer for whom it acts a real voice in the negotiations that determine the selling price of his goods. The man who announced to the world that it takes two to make a bargain never witnessed a transaction between a capable buyer of farm products and a small farmer, helpless in his ignorance of general market conditions and tied up by the necessity of selling promptly; and certainly that sage never dreamed that whole communities of producers might dump the fruits of their annual labors into the indifferent markets of distant cities without regard to any relationship between supply and demand, there to be sold for whatever they might chance to bring. More than ninety per cent of the total output of the Exchange is sold f. o. b. loading point, the exact price being a matter of contract before the cars roll, and the small remainder which is consigned to its authorized selling agents in near-by markets being mainly odd lots and goods of inferior grade or doubtful keeping qualities which it is unwilling to put out to its regular trade. In pushing the sale of its products, the association has been constantly reaching out into new territory, until its market, which was at first confined mainly to a few eastern cities, now includes a considerable part of Canada and practically the entire United States east of the Pacific slope. To provide a more direct and personal means of communication with its trade, the Exchange has found it advantageous to station its own men throughout the selling season in many of the leading market centers. This year it sent out from its general office representatives to Boston, Toronto, Buffalo, Detroit, Scranton, Pittsburgh, Chicago, Kansas City and Davenport, Iowa, and next year Montreal and probably St. Louis will be added.

Again, the Exchange aims to substitute an intelligent singleness of control and unity of action in the marketing of the products of the peninsula for unrestrained and often frantic competition among a great number of small producers. It may be objected that this is monopolistic. It is. But monopoly is not per se and under all circumstances a matter for just condemnation; and the sort of monopoly that has made the term odious has not been, and is not apt to be, a monopoly effected by small farmers in a restricted agricultural section. Whenever in any industry the individual producers are so numerous, their separate output so small in volume, their resources and facilities for utilizing potential market advantages so scant, and their needs so pressing as to render unrestricted competition between them disastrous to their industry and to destroy the incentive of a normal degree of profitableness, then combination, and if you will monopoly, between them is not only justifiable but demanded by the best interests of the country at large. On the Eastern Shore, in the five years preceding the organization of the Exchange, the marketing of farm products was coming gradually into the hands of a class of men known as "local buyers," of whom one or more could be found at every loading point. 
These men bought from the farmers, generally to fill orders previously booked. As a matter of actual experience, the competition was all in the selling end of their business. The farmers, uninformed as to general market conditions and forced by the perishable nature of their goods to make quick sales, were helpless to do any real bargaining and pretty generally accepted whatever price the local buyers offered. Moreover, as these local buyers were men of small capital and worked generally for a per package brokerage or margin of profit, regardless of whether prices happened to be high or low, they had a very positive interest in establishing and maintaining a low range of prices. And the actual and inevitable result of their activities had come to be that after a brief period of early high prices, before the general crop movement was well under way, the market would fall to about the lowest level at which the farmers could be induced to pack and haul out their already matured products rather than leave them to rot in the ground. It was a realization of the abuses inherent in this system of "laissez faire" marketing and a determination to supplant it that furnished the initial momentum for the movement to establish the Exchange.

Again, the Exchange stands for the standardization of farm products. It aims to get the farmer more for his goods by making those goods intrinsically worth more - and above all, by making their worth more certainby making the contents of his packages a fair inference from the manifest and the top layer, and not, as is too often the case with the farmer's pack, a mere matter of conjecture. When the Exchange member hauls his goods to the station, they go first to the local inspector, who must examine and pass upon them, emptying a barrel at random from every load, before they go into the car. Certain definite standards of culling, of size and filling of packages, and of quality and condition of contents, are insisted upon; and only goods which meet these requirements are. sold under the association's official mark of approval-its registered trade mark, the Red Star Brand. To promote uniformity and insure certainty of inspection, a general inspector, having now complete administrative control of the entire force of local inspectors, with power of removal, and provided with an assistant, travels constantly from one shipping point to another, coaching and reviewing the work of the local inspectors. The process involved, as it affects the farmer, is one of education, and therefore slow, and the results thus far attained leave much to be accomplished, as an occasional letter from some exasperated customer still forces us to admit; but great and permanent progress has indisputably been made in this field of the association's labors, and it is not too much to say that the Red Star Brand has now acquired a national reputation among produce dealers, which insures the goods that bear it a preference in practically every important market in the United States.

And finally, and more comprehensively, the Exchange aims at, and has in large measure achieved, first throught the natural economy of operat- 
ing on a large scale, and secondly through the elimination of useless middlemen and the simplifying of unnecessarily slow and complicated marketing processes, the lowest possible cost of distribution. It gets for the farmer a larger number of the hundred pennies in the ultimate consumer's dollar, not by increasing the size of that dollar, but by reducing the number absorbed in the tolls and wastes of unintelligent, haphazard methods of distribution. To illustrate by a rather extreme example, under the old system of marketing still in vogue in many sections, the farmer ships twenty barrels of sweet potatoes "on consignment" to a commission merchant in New York, who, as the market in that city happens to be glutted, sells them for a trifle more than freight charges to a speculative buyer, who combines the $m$ into a car with a hundred and eighty other barrels similarly bought and sells them at a profit to a Chicago dealer, who resells them at a further profit to a wholesaler at Milwaukee. The farmer gets nothing; but Mrs. Janssen, of Milwaukee, who buys a half peck of these potatoes, must pay a proportionate part of the profits of these several dealers, of the several separate assessments of freight, and of the shrinkage in the car by reason of its several handlings and of the long delay. Under the present system, the Exchange sells direct by wire to the wholesale dealer at Milwaukee, who is on its regular quoting list and with whom it is in direct and constant touch; the original twenty barrels of potatoes move out with those of other members of the association, the same day they are loaded, direct to Milwaukee under a car-lot rate of freight; the Milwaukee dealer and Mrs. Janssen pay probably about the same; the railroads lose their freight charges for the roundabout, double haul; the commission man, the speculator and the Chicago dealer find, let us hope, more useful employment; and the farmer gets a living price for his goods.

The Exchange, be it remembered, has no quarrel with the economically legitimate middleman. And in particular, we believe that too much importance has been attached to the dishonesty of commission merchants; that for every dollar filched from the American farmer by the dishonesty of a commission merchant, a hundred have been lost through his own stupidity in blindly following unintelligent and outgrown methods of marketing. In our industrial life, the processes of distribution are just as important as those of production; the man who in any efficient way facilitates the transfer of our farm products from those who grow to those who eat them is just as truly and creditably helping to feed the country as the man that guides the plow. But whenever the machinery of distribution is found unnecessarily cumbersome, when its processes are needlessly complex and circuitous, when the movement of its products departs from that commercial straight line which is the shortest practical distance between the two points of producer and consumer, then the superfluous middleman is an economic nuisance and his earnings an intolerable tax. And it is in the discovery and elimination of these needless complexities, in the blazing out of new trails of commercial direct- 
ness, that these farmers' exchanges now springing up all over the land have their basic function, and in the consciousness of aiding to bring the great work of distributing our farm products up to the same standards of enlightened and enterprising efficiency that prevail in other departments of our national industry that the architects and inciters of these movements must find their chief satisfaction. And if in my fragmentary account of the work of the Eastern Shore of Virginia Produce Exchange there has seemed to be nothing very new or remarkable, if its aims and methods have seemed merely analogous to those of any other well-regulated business enterprise, I ask you to recall Doctor Johnson's illustration of the dog walking upon its hind legs - a performance which he described as not remarkable in itself, nor for the intrinsic excellence with which it was done, but because it was a dog that did it-and to reflect that the true import of this work and the augury which it carries of a better era lie in the fact that it has been the unaided work, in a typical community, of the American farmer, who has so long been the dog, and the under dog, in our industrial life and has so generally been contented to go aimlessly upon all-fours in the vital matter of the marketing of his products.

Mr. Calwell: We have with us Mr. Stubbs, who is chairman of the Agricultural Committee of the Pennsylvania Bankers' Association. I would like to give him three or four minutes if he will come to the platform.

Mr. StubBs: When we are told, as we just have been told by Mr. Harris, how many acres we control in Pennsylvania, of course we then have to consider ourselves bankers. We have no doubt all listened to the pamphlet Mr. Harris read on Pennsylvania Agricultural Statistics, showing Pennsylvania in the rear. I attended, as Mr. Harris has told you of, the convention in Minneapolis and in Kanșas City. I must say I was ashamed to see how lacking we were in interest in agricultural matters. Mr. Harris has certainly given us a splendid address, and I believe this subject of extension work of agricultural colleges is going to be more and more an important factor in their work, and we need to interest ourselves in it. The members of the Pennsylvania Agricultural College, Mr. McDowell and Mr. Watts, have already told us of some of the work being done there and also as to the annual appropriations the college receives from the state, last year $\$ 20,000$ being appropriated. And I think you will all agree with me when I say the work of the field demonstrator is a most efficient medium in extension work. As one of our Washington men has told us, when he sits in his office in Washington and sends out circulars and correspondence, progress is slow, but when he goes out or sends representatives to the states in the South where he has been doing the work, then he gets results. We want to advance along the line of the field demonstrator. It is certain that the Committee on Agriculture of the Pennsylvania Bankers' Association will again come to you in an effort to have you 
help along this important movement. Our college authorities tell us we helped some in getting that appropriation through last year. They want to advance it the next time, and what better service can we give than to help that movement. The college authorities tell us they want to fill in the missing link between themselves and the farm by the farm-bureau man and the field demonstrator. They said it is necessary that we put some college men out into the field demonstrating, where they will talk to and show the farmer, and we hope you will help Pennsylvania State College along this line. It is not merely a question of getting into this work out of sympathy, or anything of that kind, but this movement is getting big, and the banker has been backward in getting into it. Something is going to come of this movement, it is going to crystallize sooner or later, and the bankers better be in it, because we want something to say on these things along financial lines, and the bankers ought to have a part in it. So far as the Pennsylvania banker is concerned, I think we are progressing in it, because we have the Corn Exchange National Bank as a member of the Pennsylvania Bankers' Association and they have been doing a splendid work. It was a novel idea of Mr. Calwell's in starting this corn show and giving these cash prizes $(\$ 1,250)$ and we ought to be glad we have in Pennsylvania a banking interest in this movement. Do you know if there is any state in the Union that has a national bank taking such an interest in this movement as the Corn Exchange National Bank of Philadelphia? So I say we must be alive ourselves if we are not going to be ashamed of ourselves by not devoting at least a portion of our time to this great question of agriculture among the banking interests of the country.

Mr. Calwell: Mr. Forrest Crissey, whose name is on the program, is not here today and we have an old Corn Exehange Bank boy with us. $\mathrm{He}$ is standing there near the door. [Applause.] If he hadn't gone out of the bank some years ago, he would have my job today. $\mathrm{He}$ is engaged today as city statistician. I am going to ask Dr. Cattell to speak to you. 


\section{ADDRESS.}

\section{By Edward James Cattell, Statistician, City of Philadelphia.}

I welcome from my heart the opportunity which Mr. Calwell has given me to address this important body on this important subject, because this meeting appeals to me strongly, not only because of the vital necessity of studying agricultural problems, but because I can speak to you as an old bank boy-one whose privilege it was to labor in the Corn Exchange National Bank nearly fifty years ago.

I am further glad to speak because it offers opportunity for me to thank the preceding speaker for his most illuminating and interesting explanation of the system established on the peninsula for the handling of farm products, which certainly points the way along which an immense amount of good can be accomplished, resulting in added wealth to the producer and, through an increased volume of products, reducing cost of living to the consumers.

While he was talking, an old memory of a visit to the eastern shore came back to me with compelling force-a visit on a farm, when young, where I met the two laziest men I have ever come across in my world-wide journeyings. These brothers were so lazy that it took two of them to sneeze, one to throw his head back, and the other to make the noise; and they would sometimes wait an hour, or two hours, the one for the other, rather than essay the awful strain of sneezing individually. I do not for a moment mean to suggest that this traditional opposition to labor still prevails in the peninsula today, or that it is in any way responsible for the necessity which has brought about this splendid system of distribution. At the same time, it may suggest a certain line of development which promises great returns to the nation at large, namely, a more energetic and intelligent handling of the food-producing question. We have fallen, of late, into the habit, especially in financial centers, of regarding this country as practically a finished country. It is the commonplace of our public speakers, and of the press, to refer to the good old days when there were plenty of opportunities, plenty of unoccupied land, and the nation was just being opened up. Of course this is all nonsense. After an agricultural development which has staggered the world by its rapidity, we have still awaiting utilization practically three-fourths of the surface of the republic; and if you take into consideration the multiplication of producing power, born of intensive farming, it is almost impossible to measure the extent to which we can increase our product from even our present- 
day area of cultivated land. For when you remember that we, on practically virgin soil, are raising crops less than one-third the volume raised in Europe on land tilled for more than a thousand years, a faint idea is obtained of the development ahead of us if we do our duty.

When, also, it is recalled that in many sections product per acre has been raised, in certain crops, from 30 bushels to 300 bushels to the acre, there comes a vision of a new America, and a new area of prosperity, alongside of which all other eras will seem practical failures.

We must look at this question on all sides, and that is the great advantage of just such a convention as this, where men who are scientifically trained to approach great economical questions, who are accustomed in their daily business life to measure probabilities underlying various kinds of projects, put their whole attention for a time on this one great question of producing and marketing agricultural products.

As I have already said, it is dangerous to regard a question from only one point of view and to believe that this point is the only point. That lesson was driven home to me recently when driving a car along a New Jersey road. Rounding a corner I found my progress blocked by an overturned load of hay. The driver of the team was slowly endeavoring to clear the roadway. He seemed so hot and tired that I suggested that he take a rest for a few moments. "No!" he answered sharply. "I cannot stop; father wouldn't like it." His manner, as well as his words, rebuffed me, and I lit a cigar, paced up and down for five minutes, then the fellow's evident exhaustion made me feel it my duty to again warn him. Putting my hand on his shoulder I said, "My dear fellow, you must rest for a few minutes; you are getting dangerously hot." "No!" he again replied, "I cannot stop; father wouldn't like it." Annoyed at this seeming excess of meekness, I exclaimed," "Where is your father?" "Under the hay," was his terse answer.

In this case I had misjudged the whole situation, blaming the man's risk of his life to a fear of a scolding from a father safely resting at home, whereas the case did justify active effort on the part of my new acquaintance. This, as I say, suggests the necessity of looking at this question from all points of view, and I believe if that course is followed one of the first points that will impress itself deeply on the fair-minded student is a fact which has given me cause for serious thought. I had noted, as you all have noted, the tremendous amount of space occupied in the press with record of speeches and articles charging excessive freight rates on the railroads, and ascribing many of our ills to this condition. What a new light is thrown on this whole subject when, studying a little deeper, we come to realize that all this agitation has to do with freight rates which figure at less than one cent a ton a mile. Meanwhile, nothing, hardly, is said of our foolishness in following a policy in road development which places upon our moving crops an excess cost of certainly not less than fifteen cents a ton a mile. 
A short time ago I investigated the movement of merchandise and crops from point of production to point where they first reached a rail or river shipping station; in other words, the distance the articles were transported over the old roads of the country. This worked out an average of nine miles, at a cost of 25 cents a ton a mile. Had these roads been in proper condition, the cost would have certainly not been more than 10 cents a ton a mile. This condition is due to the fact that practically nine-tenths of all the roads in the country are in exactly the same condition as when finished by the first settlers. This handicap on general prosperity represents not merely the added cost of moving food and various kinds of product, but this high toll on the initial movement is so great, that millions of tons of product rot back to nature and play no part in creating that exchange between various types of producers, which is the foundation of a country's prosperity and the advancing condition of its civilization.

A few years ago it was shown that more than six hundred million tons moving on the railroads had a value at point of production less than one dollar a ton. This figure illustrates what a tremendous factor this excess cost of movement over roads to initial point of shipment is in the general run of affairs; for this excess is greater than the average value of this immense body of product.

I feel that one result of this convention will be a closer attention to the question of good roads and a proper utilization of such roads as now exist by a system of gathering product in small quantities from farmers of a common neighborhood, concentrating into salable lots many small bodies of product which now, because of their smallness, will not pay cost of packing, transportation and distribution in the cities.

I am naturally an optimist, and the longer I live the stronger grows that optimism. Only recently a friend called to see me, a dear old Irishman who has never outgrown his habits and forms of speech acquired on the other side of the Atlantic. "Well, Mr. Cattell," he exclaimed as he entered my office, "I'm going out to the Sandwich Islands;" to which I replied, "Man alive, you cannot stand it. I have been out there myself and it is 185 degrees in the shade." Back came his answer, "By the saints, I needn't stay in the shade all the time!"

We want more of this self-confidence, this belief that even if we do not understand a situation our native ability will show us some way to change our position for the better. Then, too, we want a little of the spirit, it seems to me, of another acquaintance, living here in Philadelphia, whose ill-fortune it was to fall from the roof of a very high building; and by the testimony of those occupying offices in the building, this man, as he passed each floor in his perilous descent, exclaimed, "Don't worry, I'm all right up to the present time." He evidently waited for the final bump and tried to enjoy himself during the trip before that bump arrived.

I suggest, therefore, that this convention, when it dissolves, and its units return to their home environment, carry back, each to his special 
circle of friends, the high resolve to look hopefully to the future; to wait until trouble comes before bearing the suffering incident to that trouble; to realize clearly that every American is here enjoying a unique position; that every American is a sovereign of divine right, with some special work to do, allotted him by the living God, which no other man can do-work which, if he leaves undone, somebody, somewhere, is certain to suffer loss from his neglect. Let us all remember that experience which Mr. Carlisle had when he went to make complaint to a neighbor about the suffering caused by the crowing of this woman's game cocks at night. "Madam," said he, "I cannot stand their noise, they drive me crazy." "Why, Mr. Carlisle," replied the woman, "you are exaggerating. The poor birds only crow three times each night; each crow only lasts three seconds; what are nine seconds of suffering to a strong man like you." "Madam," exclaimed Carlisle, "You don't know what I suffer waiting for the damn things to crow."

Let us drop this habit of waiting for trouble and anticipating disaster. On every side are hopeful signs if we will only read them with honest eyes. In $1869 \mathrm{I}$ crossed this continent on the first roads linking the Atlantic and Pacific. On that journey I traveled five days over a tract of land which every map in the world described as the American desert. Today, thanks to science, in the heart of that desert they are raising three crops a year. I can well remember the day when all through the South notices were posted threatening a fine to people who left cotton seed as waste in the streets. Today that despised cotton seed, thanks to science, furnishes us a credit balance, through exports, of more than one hundred and twenty-five million dollars a year. Science has done much; science will do more. Today we take five hundred and seventy million tons of coal out of the earth annually, wasting two hundred and fifty million tons under ground. Science will show us how to save this waste of two hundred and fifty million tons. When we take into use the coal mined, we get out of it eleven per cent of its power and waste eighty-nine per cent. Science will show us how to get the eighty-nine per cent and waste only eleven per cent.

Today, there is running to waste in the rivers of the United States, three times the pulling power of all the horses of the world. Science will show us how to harness this power to the uses of commerce and manufacture, and a new body of purchasing power will be called into existence. Dry farming methods in the West, drainage of submerged land in the South, reclamation of arid land in all parts of the country, are creating each year a new farming republic; and he who is a pessimist in face of such conditions, it seems to me, should consult as soon as possible his medical practitioner.

This conference is one which should command the respect of the whole country, for it has to do with the production of food, basis of all prosperity, foundation of all civilization. It is a great national work upon 
which you are engaged. Participating in such a meeting as this, you are playing the part of statesmen in the truest sense of the word; and I may be pardoned, I feel, if, holding this view of the present conference, I express a feeling of intense satisfaction at finding such a movement led by the Corn Exchange National Bank. One of my family was the first president of this bank, and it was through his efforts that this city of Philadelphia obtained the establishment of League Island as a great Naval Station - a naval station which some day, in time of peril, may prove the salvation of the whole country. The Corn Exchange Bank, with its associate the Corn Exchange of Philadelphia, ${ }^{*}$ in time of national peril rallied to the support of the National Government, organized and equipped an important regiment of soldiers, and out of a small membership contributed three hundred and seventy-five thousand dollars to their support and maintenance.

These facts are mentioned here, and by me, merely to suggest the thought that the Corn Exchange Bank is only following its tradition in thus inaugurating a great national movement like this Agricultural Conference, for participation in, and leadership of, truly patriotic movements has always been the practice of the Corn Exchange Bank.

In closing, I want to put before you a little picture which always confronts me as the Christmas season draws near, lending to that season a certain note of feeling which it might otherwise lack. Years ago, traveling down the Volga, in far Russia, I stopped at a little village where all the people were engaged in making toys-making toys which were sent all over the world at Christmas time, to tell in their own sweet way the story of the Christ to other children and to older folks who still hold the child heart clean and sweet, even if gray hair had come to be their portion and their crown. As I watched these children in this village fashioning toys, little children who as they worked looked out through narrow windows upon a vast stretch of untilled land, land untilled because of bad governmental conditions, one of the children dropped the toy upon which she was working upon the hard, earthen floor. I said to my guide, "Is she nervous because I'm watching?" "No," he replied, "she is weak from hunger. All our children are always hungry." It is a peculiar fact that hunger and harvest have the same root in the Russian tongue; and the saddest music I have ever listened to is the song of the Russian reapers as they come back from the fields after harvest.

Gentlemen, we are about to enter the Christmas season. Each will find in his own home environment a new reason to love life, a new incentive to make life more lovable for others; and my prayer to you tonight is that you will bear in mind what I have said of these hungry children in far Russia, a land with an area as great as the whole North American continent, and as you remember these other children always hungry, in a land where food should be plentiful, you should ask God to help you to utilize every natural

\footnotetext{
*Today known as the Commercial Exchange.
} 
gift in your possession, to the end that the law-abiding spirit of our people may increase, that love of country may develop a spirit of statesmanship that will result in wise laws, and that a movement of this character, having for its object a better utilization of God's great gift in the shape of fertile lands, may receive from you your best efforts, your highest energies, so that never may it come to be said by a visitor to this broad, brave land, that our children are always hungry; that the reapers returning from the harvest field sing a song that wrings the heart with its pathos and its despair.

Mr. Calwell: Mr. Cattell has emphasized the Corn Exchange Bank. But I didn't know he was going to do it, as the Corn Exchange Bank is not the whole thing in this movement.

On the front of this programme you will see the various organizations in this city who have taken part in this movement, the various educational societies and last, but not least, I would call your attention to the Pennsylvania Rural Progress Association, and the Philadelphia Society for Promoting Agriculture.

Mrs. Smith and Mr. Kates, who represent those associations, have both worked very hard for this programme, and the success of this convention and conference is in great part due to their efforts.

Gentlemen, I thank you all.

[Adjourned to 8 р. м.] 
Saturday, December 6, 1913, 8 P. M.

Council Chamber, City Hall, Philadelphia.

Mrs. Sмith, Chairman: As this conference is about to come to a close I would like to say a few words to you as to how this conference came to be. It has been accomplished through the eo-operation of the Corn Exchange Bank, the various trades bodies of the city of Philadelphia, the Philadelphia Society for Promoting Agriculture, and the Pennsylvania Rural Progress Association-all represented in this conference.

I want to ask every one of you who come from other cities to take home with you some of these programmes, and we would like to call the attention of the various chambers of commerce and bankers of your towns to this conference that the Pennsylvania Rural Progress Association proposes to be available for the getting up of other conferences such as this. Outside of Philadelphia we organized a conference lasting three days last spring in Williamsport, in co-operation with the Chamber of Commerce. It will help agricultural progress and bring the city and country in closer touch and do a great amount of good.

So let me tell you the Rural Progress Association of Pennsylvania stands ready to organize conferences of this sort in any small town or large town. That we only have to hear from the people in order to come there and make arrangements to make up a programme to last a day; an afternoon, or evening, or last three days if it is desired. And that is just what we hope to be able to do for Pennsylvania, to bring about a closer touch between the town and the markets and the rural districts.

I want to introduce to you Mr. Russell R. Lord, of Baltimore, who will speak to you for a few minutes. 


\section{DEMONSTRATION OF AGRICULTURAL HIGH SCHOOL METHODS AND RESULTS.}

\section{By Russell R. Lord, Abram Pearce and Lee Parry,}

Three Graduates of the Sparks (Md.) Agricultural High School and Members of the Boys' Committee on the Oread School of Country Life.

Russell R. LORD: I am one-third of three country boys who have tackled a big job,-a kind of agricultural three-ring circus on our own hook. This show which we have gotten up for your benefit is intended to give an idea of some of the methods by which our alma mater-the Agricultural High School at Sparks, Maryland,- -has succeeded in raising the entire countryside, which supports it, on a superior plane. In the five years of its existence it has made grow the proverbial two blades of grass where before there was but one; better still, it has made grow two thoughts where before there was but one.

Some of these soil experiments which we bring to you are those which performed in the school laboratory, gave rise to the alarming rumor over the farthermost ends of our county that "they don't do nothin' at Sparks but make mud pies." As a matter of fact, much of our soil physics demonstration is just about as simple and easy as making mud pies. But I believe that you will see a very real method in our madness. And perhaps you will begin to suspect, before we finish our performance, that a great deal of agricultural high schooling is play-and blamed interesting play at that. . I am almost prepared to say that the true success of our school lay in its putting everyone-old and young-to playing agriculture profitably. Properly played, you know, the game of farming is just as much fun as the game of baseball.

Aside from my duties as ringmaster of this show, my real excuse for being on my feet is to tell you of my short experience in "Making Corn Make Good." It is neither profound nor astonishing, but I believe that I have chanced upon some figures that mean dollars in or out of the pockets of everyone in this audience who grows corn, or feeds it, or eats it himself.

Every person in this room, as well as every ear of corn on our demonstration table, has been shaped by two great fundamental forces-environment and heredity. Heredity furnishes the material, good or bad; environment molds it, for good or bad.

As in the case of people, almost all the attention is paid to the environment of a corn crop. Great pains is taken in the molding, regardless of the inherent merit or demerit of the material. The newest method of making corn make good might well be called corn eugenics. 
A great many of you know the story of "Boone County White." Its introduction into our county by our school has resulted in an annual increase in the value of the corn crop sufficient, economists figure, to pay for the school every year.

My experience with corn started in 1910 when, with four other fellows, I ran, as my summer experiment required by the school, a variety test plat. The following were the results:

$\begin{array}{lcccc}\text { "Boone County White" } & \text { yielded } & 14.8 & \text { barrels per acre. } \\ \text { "Selection 77" } & \text { " } & 13.2 & \text { " } & \text { " } \\ \text { "Clarage" } & \text { " " } & 12.2 & \text { " } & \text { " } \\ \text { "Hybrid 100" } & 10.2 & \text { " } & \text { " } \\ \text { Home Grown Sced (Scrub) } & \text { " } & 10.0 & \text { " }\end{array}$

Selecting seed-ears from my Boone County White test-plat, I planted them in my contest acre the following year. I raised 13.2 barrels from that acre. Every ear of it passed through my hands, and the result was about six bushels of ears of almost show form. By elimination, I picked the best hundred of these, then the best fifty. Scoring this fifty carefully, I got the best twenty-five ears, and numbered them.

This brings us up to the first breeding plat I ran, and forces me to pause in the narration of what I did and tell you why I did it.

A corn seed is an embryo; an egg is also an embryo. "Can you lcok at an egg and foretell the chick? No. Neither can you look at corn and prophesy the progeny. "Like begets like," you say, and high-class ears should produce high-class ears. Perhaps. But is there anything in the appearance of an ear of eorn that accurately indieates its power of profitable production? Absolutely nothing.

All of these carefully picked ears which I had selected possessed quality. But we want more than quality; we want quantity, for after all that is the thing that fills the corn crib. The twenty-five selected ears looked good, but would they make good? I did not know; nobody could tell me; I had to try and see.

So, simply said, that is what a corn-pedigree plat is,-- "to try and see." To take grains from the best ears you can find-from the standpoint of external appearances - and plant them, side by side, under equal conditions. Then to measure the comparative yields; and use the winners for the sires and grandsires of your confields-to-eome.

With this end in view, I took a level, uniform piece of land and laid it off fifty hills square. This gave me fifty eorn-rows of equal length and worth divided up into fifty equal portions. In rows Nos. 1, 3, 5, 7, etc., I planted assorted seed from the strongest specimens of seed-ears I could get. In rows Nos. 2, 4, 6, etc., I planted half of the grain from ears Nos. $1,2,3$, etc., respectively. When these ear-rows eame into tassel the tassels were all pulled out and only the pollen from the mixed rows allowed to pollenize the tested or female rows. This was done to prevent inbreeding and consequent deterioration. 
In the fall the male, or mixed rows, were first gotten out of the way. This simplified the plat to twenty-five standing lines of 150 stalks, each line representing the producing power of the ear whose number it bore. The rows were then carefully harvested and their crop weighed separately. The most amazing variation lay in the yields of the seed from ears Nos. 24 and 25, growing side by side under environmental conditions as identical as it is possible to obtain. No. 24 gave 230 pounds of cob corn; No. 25 gave but 72.6 pounds. At the time I hesitated in emphasizing this great discrepancy, thinking it might perhaps be merely a freak, but since then talks with authorities and a repetition of the result in another breeding block have convinced me that heredity does cause just such enormous differences in yield-even higher than 400 per cent sometimes. Here is a tremendous, unseen, unvarying power which, controlled, enables a man to double his crops and then double them again without even touching a plow handle.

With these results in hand, I saved the half-ears-(known technically as remnants) - which had performed the best. Then from the thirteen acre cornfield of our home place I went to work again and carefully selected twenty-five other ears after the manner of the previous year. To add to the interest of the next year's work I took care to thoroughly examine each ear and accurately score it. I determined the percentage of excellence of the ear as a whole, then of the grain; and then I weighed ear and shelled seed for the percentage of ration of corn to cob. These three ratings I averaged and called the result the "average apparent excellence" of the ear. My motive in doing this was to try and see if any relation really existed between the "average apparent excellence" of a seed-ear and its performance in pounds in the field.

I planted my plat of 1913 much after the manner of that of 1912, excepting that, instead of unknown mixed grain, I was able to sire it with the leading 1912 remnants of known performance, thus obtaining a partial "double-pedigree" system. Here (pointing to chart) are the weighed results of this year's work:

Copy of Chart Displayed in Illustration of Making Corn Make Good.

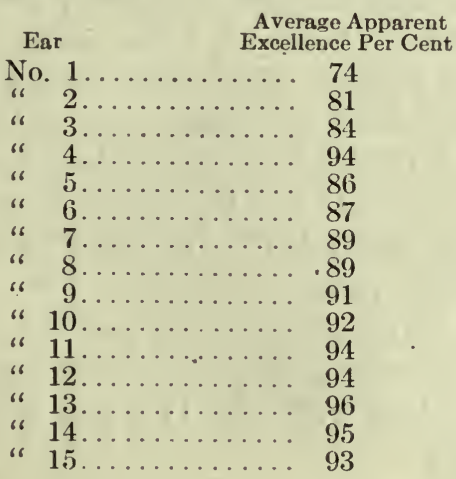

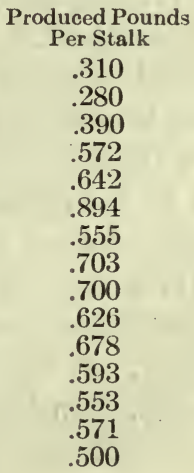


Copy of Chart Displayed indllugstration of Making Corn Make Goop.-Continued.

\begin{tabular}{|c|c|c|}
\hline Ear & $\begin{array}{c}\text { Average Apparent } \\
\text { Excellence Per Cent }\end{array}$ & $\begin{array}{l}\text { Produced Pounds } \\
\text { Per Stalk }\end{array}$ \\
\hline No. 16. & $\ldots \ldots 92$ & .600 \\
\hline " 17. & $\ldots \ldots$ & .643 \\
\hline 18. & $\ldots \ldots$ & .620 \\
\hline “ 19 . & $\ldots \ldots$ & .567 \\
\hline " 20 . & $\ldots \ldots$ & .668 \\
\hline " 21 . & $\ldots \ldots$ & .500 \\
\hline " 22 . & $\ldots \ldots$ & .443 \\
\hline " 23 . & $\ldots \ldots$ & .724 \\
\hline " 24 . & $\ldots \ldots$ & .558 \\
\hline " $25^{*}$ & $\ldots \ldots$ & \\
\hline
\end{tabular}

* Ear-Row No. 25 thrown out because of extremely poor stand.

You will notice that, following the advice of Dean Hunt, I renumbered my ears after scoring them, making my best apparent ear No. 13, my next best No. 15 and No. 12, and so on, the two lowest scoring ears being No. 1 and No. 25. This arrangement does not seem to have impressed itself much upon the rank of performance. For instance, you will notice that No. 24, the worst scoring ear of the bunch, outyielded No. 13 , the best.

This time the extremes come a trifle closer together. The best, No. 6 , produced something over eight-tenths of a pound of corn and cob per stalk. The worst, No. 2, produced but little over two-tenths of a pound. Still a difference due to heredity of almost four hundred per cent.

The result is, as you see, given in fractional, or rather decimal pounds. The extreme left-hand column represents tenth-pounds, the middle hundredth-pounds and the one on the right thousandth-pounds. You may imagine that this is splitting hairs, but remember this is per stalk, and a cornfield is a vast forest of such stalks.

I figure that, presuming you were to plant an acre from identical ears, a difference of one figure in the right-hand column means a difference of ten dollars' worth of corn in the resulting crop; that a difference of one unit in the middle column means a gain or loss of a dollar on the acre; and that a difference of one in the third column means ten cents, lost or gained.

Take, for instance, ears Nos. 21 and 15. Both produced an even half-pound per stalk. Ear No. 16, however, which looked exactly like the rest, produced six-tenths of a pound. That extra tenth-pound per plant would mean that a man would make ten dollars an acre by planting such as it, rather than such as Nos. 15 and 21, or their inferiors. And if he had planted all such as these (pointing to No. 9 yielding .700) he would have gained twenty dollars per acre, and this (No.6) would have added almost twenty dollars more to his crop income.

It is perfectly possible to plant only such ears as thls No. 6, and profit thereby. It is also perfectly possible for you to drift along as you are now doing, planting 24 's along with your 17 's, just as they come, and losing hard, cold cash thereby. 
A proper environment is only half of farming. High heredity is the other half. You control environment to your profit. You can likewise control heredity. It is no easy job. But it is a job well worth while and something which you will all come to sooner or later. The grab-bag method of selecting seed must die because it is expensive and foolish. And if you are wise you will start now to prepare for your cornfields of 1914, '15 and '16.

[Abram Pearce was next introduced for a brief talk on "Winning the Corn Cup." He described his methods of securing strong seed, and the methods which he followed in the fertilization, cultivation, and harvesting of the acre of corn which produced the highest yield at the lowest cost of any in Baltimore County, and so won for him the silver loving cup offered through the Baltimore County Association of Boys' Corn Clubs.

As the President of the County Association, he was further able to speak interestingly of the unique system of boys' club work, carried on entirely by the boys themselves, and through which the Agricultural High School has been able to make its influence strongly felt at points far removed from the Sparks community. Prolonged applause marked the close of his talk.]

Russelu R. LoRD: Now comes the demonstrational work. In experiments of his kind, about a million things can happen that you never expected to happen. Perhaps some of these things have already happened, and if some of the stunts don't quite work out, we hope that you will laugh with us and proceed happily on to the next. However, everything looks all right and we are ready to start it off. Lee Parry will tell you some things you don't know about a generation of corn while Pearce and I will work the demonstrational end. This is Lee Parry.

LeE Parry: As you have already heard, the ordinary generation of corn starts with the planting of the seed in the spring. A successful generation, however, should start several seasons back of that in careful selection and painstaking upbuilding of a good strain of seed of a variety ideally adapted to the personal need and environment. Assuming that this has been done-which is quite a bit easier than doing it-let us say that we now have a bunch of ears of perfect pedigree from which we desire tọ select the most promising individuals for perpetuation. I have here [indicating a display of about a bushel of ears of all types and sizes] a bunch of average Boone County White ears picked haphazard from a corn-crib. Which is the best? Which is the worst? Why? To answer these questions we must have a definite and concise idea of what an ideal ear of White Dent corn looks like. While I am describing this ideal ear, the other boys will judge this bunch of ears and pick out the best.

A good ear of corn should be of goodly length, cylindrical in profile, well rounded at butt and tip and tapering gently throughout its length. 
The circumference of the ear should be at least 75 per cent of its length and the depth of its grain at least half the diameter of its cob. Shelled, the grain should occupy as much space as did the ear before being shelled. Furthermore, the ear should be unmixed in grain and generally true to variety and type characteristies. It must look like an aristocrat to the eye trained to judge. These points are rather sketchy, but they should give some sort of mental picture of the real thing and enable you to judge whether or not the boys have picked the right one. Which is best, fellows?

[Best ear displayed and points briefly enumerated.]

This selection of seed-ears, to have been ideal, would have taken place in the early fall. The next thing is to store it safely away from vermin and extremes of heat and cold. Corn stored in corn-cribs usually retains some moisture up to the time of the first sharp freezes. These, alternating with early thaws, effectually kill the germ of the seed and render it useless for perpetuation. The best way to store a small amount of seed corn is to string it up and hang it away in some place protected from extremes of temperature and the best way we know of stringing it up is the way Pearce and Lord are now illustrating.

[Brief demonstration of stringing corn by the double-string, interlacing system.]

Let's now imagine the winter past and the sun shining on the plowed fields. It's almost corn-planting time, but before that there is just one more little trick which may add dollars to the farmer's pocketbook and subtract days of hot, tiresome replanting.

This little affair [indicating germination box in various stages of development] can be knocked together on any farm in ten minutes. Simply make a shallow pan-like box, fill it with clean sand or sawdust, divide it into squares with strings and you are ready for your test planting. You can see from the way the boys are now doing it, that it is no hard task. Number the ears under test, then take from each ear six grains-two from the tip, two from the middle and two from the butt. Plant them in the moist compartment eorresponding to their number. In a few days they will sprout,- that is, some of them will. Discard all ears which, from the six sample grains, do not throw out at least five strong shoots. Here [indicating rag-doll tester] is an even simpler, but less satisfactory, arrangement. By distributing these among the rural school children of the middle West it is claimed that millions of dollars have been added to the value of the crop. It is also claimed, by way of impressing the necessity of planting virile seed, that for every dead ear planted the farmer loses four dollars.

You can see from this young corn plant [taking one from the box for examination] that the stems and the roots grow differently. These red-ink divisions were put on at equal distances. Now, a few days later, you can see that while those on the roots are at the same distance, the others have stretched apart with the growth of the stems. 
Being ready to plant our crop, let us turn for a moment to soils in general and corn soils in particular. Soil is not just dirt. It is a wonderfully interesting, wonderfully diversified, wonderfully vital thing. And let me tell you right now, it takes just as much brains to handle a soil properly as it does to handle an office full of men.

[Displaying a home-made outfit consisting of three lamp chimneys, filled with sand, silt and clay, and their ends immersed in a pan of water. It can be seen that the water has climbed highest in the clay, and lowest in the sand.]

This shows the absorbent capacity of different soils. Water is the main factor in the environmental success or failure of a crop of corn. You can see that a sandy soil is liable to prove deficient in this necessity. Generally speaking, therefore, a clay loam is best for corn. The reason the water has climbed higher in the clay than in the sand is because of the smaller pore space. Here [displaying a set-up apparatus consisting simply of two plates of window-glass touching at one end and divided by a broom straw at the other] is a simple affair which shows the thing at a glance. Here where the glasses practically touch, the water has crept up all the way to the top. Here where they are divided about a thirtysecond of an inch by this broom straw you will see scarcely any rise. The tapering line as the space increases indicates that the capillary capacity of a soil is directly proportional to its pore space.

That experiment is to show how different soils take up water. Here is another to show how they retain it. [Displaying home-made rack holding four lamp chimneys containing sand, sand and manure, clay, clay and manure. Under the bottom of the suspended chimneys are glasses. Water is poured in at the top and allowed to seep through and gather in the glasses.]

You will notice that the most leachy soil is the sand. Next comes the sand and manure, third the clay and manure, and lastly, the clay. This illustrates well the curious fact that manure applied to a sandy soil makes it more porous and to a clay soil, less porous. In this capacity of regulating the water supply of soils of different texture, manure finds a function almost as important as its fertilizing power.

These next two experiments serve to show how the corn plant draws in its nourishment through the roots. All that is taken in must be in solution. When two liquids are separated by a membrane, the less dense will pass more rapidly through the membrane. Minute membranes are at the point of every root and the soil water is drawn through them by force of the stronger sap solution within the plant. The technical name for this process is "osmosis." You will notice that here [indicating inverted tube partially filled with red liquid and separated from white solution by parchment] the salt solutions within the thistle tube has drawn the thinner liquid through the membrane and raised its level. Again, see how flabby is this piece of potato and how crisp this one is. One was immersed in salt solution thicker than its own sap; the other in pure water. 
Difficulty of transportation makes this the next to last of our experiments and lack of time forces us to take leave of our subject. But you must not think that I have told you half of the interesting things about the most interesting American crop. Do you know what corn silks and tassels are for? Do you know anything of the minute structure of the maize kernel? Do you know how and why the corn leaves roll up on a parching hot day? Do you even know why it is that when you plant white corn, white corn comes up and when you plant yellow, up comes yellow? If you know the answer to this last question and can expound it satisfactorily, do so, for nobody knows at present. There is a lot to be learned concerning corn. There is a lot to be learned, for that matter, about everything rural. And that's what makes country life worth while.

And here's the last simple experiment. It illustrates why the farmer "works" his crops. Take a plain lump of sugar, as I do, sprinkle its top loosely with pulverized sugar and dip it thus in ink. You see how quickly the ink rushes up to the top of the compact lump and how quickly it stops, and stays stopped, when it meets the loosely piled mulch of pulverized sugar. That top layer stops up the pores, and keeps the soil water from evaporating away. This, not to kill the weeds, is the first reason why farmers take the trouble to "work" their crop four or five times during the season.

To those of you who have been interested in this little show of ours, we extend invitation to visit the Agricultural High School at Sparks, Maryland, at any time, and you will see some real experiments. And you will see many other interesting things. Even the students find it interesting.

I thank you for your interested attention.

[Experimental portion of demonstration and corn breeding talk was repeated at the Philadelphia Bourse before the members of the Grain Exchange.]

Mrs. Sмiтн: We are all interested in successful farming and I will now introduce to you Mr. Honeycutt, of Illinois, who is going to speak to us this evening on this subject from a business standpoint. 


\section{SUCCESSFUL FARMING.}

\section{By JoHN P. HONEYCUTT,}

Farmer, Amboy, Lee County, Ill.

I have been requested to discuss a subject which to me appears to be of great importance to the average individual of the present and future generations. Successful operation of any permanent or enduring enterprise depends wholly upon the average net dividends from the labor and expenses of conducting the business.

How to make the farm an asset instead of a liability is a problem that is engaging the attention of a great many people just now. In fact it is causing some people to worry, and in occasional instances individuals stand up and point the finger of scorn at an individual milk distributor, produce dealer, banker, railroad man or farmer, and say, "Thou art the man who is getting the money," and immediately there is confusion, if nothing more unseemly.

Once in a great while it is necessary to fight, but earnest, careful, directed work and a pleasant smile are always in order. Let us smile and work. Personally I am glad that I am alive, and I have great confidence in future prosperity, and I say to you that so long as I am alive I am not licked. The conditions which are causing so much complaint are the result of methods, some of which were never correct, from the very beginning, and others have been outgrown. With all we have progressed and prospered. We may draw a long face and cuss the government, and all our commercial organizations, but I am going on record by asserting the United States of America has the best form of government and is the best governed country on the face of the earth today. We make mistakes, but we have sense enough to correct them without wrecking the foundation. I am a farmer and consider it an honor to be a worker in this most ancient occupation, and I believe there is a prosperous future for the business farmer.

The story of the beginning of the industry called farming interested me exceedingly. I read it in a book that is generally conceded to be good authority. I confess it has been quite a long time since I read the narrative but as I now recall it, two of our excellent most ancient ancestors made a total failure of trying to live a life of leisure, surrounded by every possible luxury. They toiled not, neither did they sweat. No matter what the reason, they failed, and suddenly found themselves thrown "back to the land," with positive injunction to make farming a paying business, with the assurance that if they worked hard, they would be 
able to enjoy life, and lay by something for the children. Farm bulletin No. 1 was brief; it said, "Thou shalt eat bread by the sweat of thy brow." This sweating talk evidently did not appeal to the folks as being in any way a reasonable proposition, and from that time until very recently, most people have been leaving the old homestead, thereby eliminating the perspiration method.

This side-stepping and evasion of the great work of production has been so persistent that the sons and daughters of Adam have gotten so far from the commissary wagon that there is a cry of distress coming from the cities, where men and women have gathered around the pretty bright lights, and "multiplied all right," but have failed to make provision for replenishing the earth. Consumers have increased faster than producers.

I congratulate our commercial men who left the farm to build cities, factories and railroads, upon the excellence of their achievements. I look with wonder and amazement upon our great commercial industries. It has been the work of giants, and never could have been accomplished without almost perfect organization and system. It is the wonderful work of men, who, qualified for their task, that has drawn a surplus of workers to the great manufacturing centers. In fact you have drafted a surplus. There are more workers today in the great cities than can find employment.

We all know the value of efficiency. Without accurate practical knowledge of the work to be undertaken, there is no hope of successful results. As late as twenty-five years ago there was hardly a factory or enterprise of any kind that could tell within a city block of the actual cost of manufacturing an article. Today there is not one worthy the name of enterprise that cannot estimate the exact cost, and their selling price is made accordingly.

While the vast army of workers have been qualifying for labor in other departments, they have been really disqualifying for the great work of actual production. For more than twenty years I had an opportunity to observe these points while engaged in commercial business in one of the greatest cities in the world. Experience and observation taught me that for the best interests of this wonderfully great country of ours, more men must engage in the business of farming, and that it would be profitable for me. Do you get that? Business of farming does not mean the purchase of a piece of land, renting it to someone else, and then trying to tell that person how to do something which you do not understand yourself. It does mean that if you intend to make a success of farming, you must understand the branch of farming you undertake. Find out in advance the crop you are to produce, and know before you produce it where you are to sell, and how you are to deliver it to your purchaser after it has been produced. It costs real money to buy seed, test seed, prepare the seed bed, and to plant the aforesaid seed. As soon as this 
same seed is planted it costs some more real money to cultivate and care for the growing crop until it is ready to harvest, then more real coin to gather and transport the crop to the railroad station and load it into the car. You may not have thought of it, but the railroads require you to pay them some more of the medium of exchange to carry your product to their freight house in the city. You have invested a considerable sum of money in land and farming implements prior to seeding time, and you are still the owner of a perfectly good crop of something which the non-producing consumer must eventually consume.

Your crop is now in the city and under the conditions which prevail today you have the choice of seeking a buyer and after making a bargain mutually agreeable, well scarcely, but after agreeing to accept the price he offers, you can deliver the goods to him and apply the proceeds, or you have the alternative of disposing of the crop at the freight house to a commission man or distributor, who is prepared and equipped to deliver it to the consumer. You receive from the commission man or distributor the "market." The consumer now may deal with the interests which have a "system" for holding and delivering economically. Here is a place in this narrative for you to smile if you are a producer, and think. Think hard, get in touch with other producers and devise ways and means. There is a way. We need the railroads, and every other large industry. We need more railroads and more big industries. We need distributors, but farmers must have a system. Think out a system. Talk it over with everyone who is interested. It will take a long time to remedy these things, but we can do it, don't back down. Farmers are the salt of the earth, the foundation and support of every enterprise of whatever name or nature. Get busy and form local organizations, and work systematically. There is no reason to be discouraged. Call on your boys for assistance in the work of organizing and systematizing your work on the farm. Send them to the Agricultural Schools, where they will learn how to think and plan. Many of your methods are obsolete, and while your experience is of great value, yet the boy, with his enthusiasm and strength of youth, will be able to suggest and assist in carrying out a new and more effective method, when he returns from school. Put the government bulletins and experiment station work in his hands. We have found them of great value in our work on Green River Stock Farm.

Farmers have, ever since I can remember, been pleased to call themselves "Independent Farmers," then smite their thigh and look wise. Independent means standing alone, and that is just the reason you are getting pushed and jostled and despoiled today. Other men recognize the value of organized systematic work, hence we have the Board of Trade, Wholesale Dealers' Association, Retail Dealers' Association, Produce Exchange, Bankers' Associations. Every craft worthy the name has an organization which is affiliated with a National Organization, and here are the grand old farmers still plodding along and bearing the burden alone. 
Cheer up, fellows, get into something. There are several departments of producers who have been organized after a fashion for a long time. Join with them, then adopt the best method for increasing your production, and work to solve the marketing problem.

Mrs. Smith: Be on the lookout for articles by Mr. Honeycutt in the Country Gentleman. That is where we were introduced to Mr. Honeycutt.

Let me introduce to you Mr. Gifford Pinchot, who is with us and will speak to us on Agricultural Co-operation. 


\title{
AGRICULTURAL CO-OPERATION.
}

\author{
By the Hon. Gifford Pinchot, \\ Milford, Penna.
}

I think it would be hard to find anywhere deeper interest in country life than you have shown in this conference.

As I read history it was not the decadence of the city that destroyed Rome. It was the gradual sinking of life in the open country, together with the existing slave system of those days. Gradually, the man who worked on the land came to be ranked as a piece of agricultural machinery, and as his status dropped it took with it the sterling qualities of vigor from the town, because all of us know that much of the best blood of the city comes in a continual stream from out of the country.

This co-operative movement rests on a new conception as to what life on the farm means. For years and years we prided ourselves because we did more for the farmers, and did it more effectively, than any other nation in the world, and it was true in a sense. Through our Agricultural Department in Washington, our Agricultural Departments in the States, our Experiment Stations, and Agricultural Colleges, we were spending money more rapidly than any other nation in the world, and all this almost wholly to help the farmer to grow better crops. We have been dealing with the farmer and the farmer's wife as men and women whose sole function was to produce food for others to eat, and incidentally getting enough food for their own needs. But we are learning slowly that it is just as important to help him get the best possible returns for the crops he grows, and to utilize those returns so as to make them yield him the best and happiest life. The problem is not merely to get better crops, not merely to dispose of crops better, but in the last analysis to have happier and richer lives of men and women on the farm.

There are certain things I would like to call to your attention about the condition of farming in the United States and the tendencies which mark it just now. During the last census period, 1900-1910, the population of the United States increased 21 per cent, but the food production increased only 10 per cent. In other words, we were adding people to our population twice as fast as we were adding food to our food supply, and it was no wonder the cost of food rose. What a farmer was getting $\$ 1.00$ for in 1900 , he got $\$ 1.67$ in 1910 . The average price of farm products had risen in ten years 67 per cent. Yet, taking the farming population by and large, in spite of this marvelous increase in what he got for his crops, the farmer has not been nearly as prosperous in the last 
ten years as he ought to have been, and he is not now. Why? One reason is that out of every dollar the consumer spends for farm products the farmer gets less than fifty cents. Where does the other fifty cents go? It goes to the railroads and the middlemen, and to the legitimate cost of distribution. Now if it is true that the best the present system of distribution can do is to double the cost of the farmer's products to the consumer, then it is certainly a very inefficient system. If it costs as much to get a pound of butter to the consumer as it does to make it, then it is a bad system and no mistake. We in the United States are just awakening to a real appreciation of the benefits of co-operation in agriculture.

Farmers in Ireland, Denmark, Holland and Belgium have had their hard times when the industry was in such a condition that man could hardly live off of it. In Ireland there were whole counties in which the average cash income of a farmer's family was only $\$ 25.00$ a year. It sounds incredible, but it is true. Then a man came back to Ireland from Wyoming, where he had been a cow-puncher-I mean Sir Horace Plunkett-and he said to the Irish farmer, "I know what is the matter with you, you are unorganized, and everywhere in the world it is the unorganized man that pays the bill." Then in little Ireland they began to organize. Ireland is a very small country, yet already 100,000 farmers are organized there. Their co-operative societies do an annual business of $\$ 16,000,000$ to $\$ 17,000,000$, and they have completely changed the whole face of agricultural Ireland.

The city is organized, the railroads are organized, the interest to which the farmer sells his product, and the interests from which he buys the things he needs are all organized. The farmer is the one great class in the United States today that remains unorganized. There has been a good deal of work done in this matter of farm organization in this country, and while I am not urging any farmers to rush into organization, I do believe that when the pinch comes, as come it must, agricultural organization is the way out. It has failed in individual cases all over this country, partly because the farmers have not realized that it takes just as good a business man to run the business of co-operative organization as it does to run any other; partly because they have allowed other men to organize them, and the organization was directed mainly toward the welfare of someone else. It has not been driven into the farmer's mind yet with sufficient clearness that co-operation in the real sense does not mean a joint stock enterprise where the voting power goes with the stock, but it does mean an enterprise where every man has the same voting power irrespective of the amount of his stock. In other words, an organization to be successful must be controlled by men, not by money. Organization is a powerful weapon, but like any other powerful weapon it is dangerous as well as powerful, and unless it is rightly used it will do no good. But the time is coming when in this country, as almost everywhere in Europe, farmers will attend to their own matters of credit, to their own matters 
of production, shipment of their product, and its disposition, so that in the end we shall have the farmer, through his organization, dealing much more directly with the consumer than he does now. It will put a lot of the middlemen out of business, and I think that will be a good thing. Some think that agricultural co-operation will have an injurious effect on the country towns. I believe that whatever makes the farmers more prosperous will make the country town that supplies the farmer's needs more prosperous. In my mind, the cure for much that the farmer suffers because he is not organized, because he does not. get a fair share of what he produces, is agricultural co-operation properly applied.

The attention of the nation has been fixed on better business, better methods of work, better living conditions in the towns. We are beginning to understand that better living is just as important on the farm, and that we must recognize the farmer and his wife as a most useful part of our population. We shall then have a greater appreciation of what this meeting means, for I think we can all put it down as an absolute fact that no matter how useful a man may be in town, the most useful citizen of any republic is now, and must always continue to be, the man who owns and tills the soil from which he makes his living. 
THE MOST IMPORTANT FACTORS IN SUCCESSFUL FARMING, IN RELATION TO DOLLARS AND CENTS.

\author{
By G. F. WARren,
}

Professor of Farm Management, Cornell University, N. Y.

During the past six years we have been securing records from farmers in New York State of their capital and business receipts and expenses in order to find out how much farmers are making and how it is that some men are making more than others. During this time we have obtained records of 2917 farms.

From seven years' study of this question we have determined the relative importance of different factors on profits.

\title{
Labor Income Defined.
}

In order to understand this discussion, it will be necessary to know what is meant by labor income. By this we mean the amount of money that the farmer has made in addition to interest on his capital. It corresponds to a hired man's wages when the hired man receives a house and some farm products.

Table 1 shows the averages for Tompkins County.* .The average capital on these farms was $\$ 5527$. This includes land, buildings, stock, machinery, tools, feed and seed on April 1st and cash to run the farm. The average receipts for the year were $\$ 1146$. Any unsold products or increase in animals is counted as a receipt. The average expenses were $\$ 389$. This includes all business or farm expenses. It does not include any personal expenses, but includes the value of board furnished to hired help.

Table 1.-Averages, Tompkins Country.

Number of farms

Average capital.......................... $\$ 5,527$

Average receipts..................... 1,146

Average business expenses..................... 389

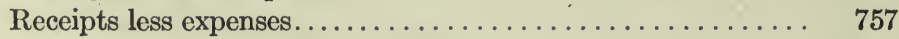

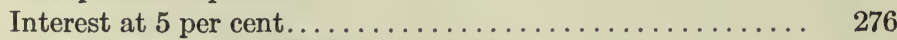

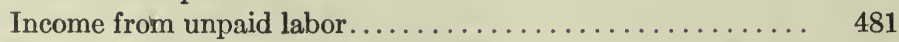

Value of unpaid labor except owner's.............. 58

Labor income.......................... 423

The difference between the receipts and expenses averaged $\$ 757$.

* For a fuller discussion of methods of work and other conclusions, see Bulletin 295 of the Cornell Experiment Station.

The purpose of this work is not to compare farming with city work, but to study the relation of varlous factors to profits in farming. The hired man and the farmer get many farm products from the farm. These and very many other factors must be considered in order to compare farming with city work. Labor income is an excellent means of measuring the suceess of a farmer as it is direetly comparable with hired man's wages when the man gets a house and farm products. 
This $\$ 757$ was earned by the farmer's money and the work of the family. Money can readily be loaned on farm mortgages at 5 per cent. Hence, only $\$ 481$ can be said to have been earned by the labor of the farmer and his family. The unpaid farm labor by members of the family would have cost about $\$ 58$ if it had been hired. The farmer really earned as his wages, $\$ 423$. This we call his labor income. Hired men in this region get about $\$ 360$, house rent, and some farm products. If a farmer's labor income is less than this, he might as well lend his money and hire out.

About one-third of the farmers in Tompkins County are making less than hired men's wages; one-third are making wages; and one-third make more than wages.

Table 2 shows the same results for Livingston County. The region is a very prosperous one and gives an average labor income of $\$ 584$.

Table 2.-Averages, Livingston Countr.

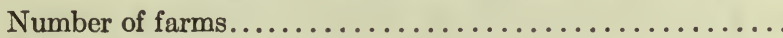

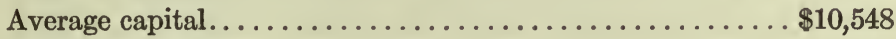

Average receipts....................... 2,172

Average business expenses................... $\quad 980$

Receipts less expenses..................... 1,192

Interest at 5 per cent.......................... 527

Income from unpaid labor..................... $\quad 665$

Value of unpaid labor except owner's............ 81

Labor income........................... 584

\section{Most Important Factors Affecting Profits.}

The four most important factors affecting profits have been found to be size of business, crop yields, production per cow or other important kind of animals, and diversity of the business. So strikingly do these four factors stand out that if we know them we can guess the labor income with approximate accuracy in about 95 per cent of the cases. Only in a few cases do practical farmers make other mistakes of so serious a nature as to prevent them from getting a good labor income when these four factors are favorable.

Farms Not Balanced.-Farmers are like other people, they have hobbies. There is practically no relationship between good cows and good crops or between size of the farm and production of crops or cows. We find that the farmers who have the best cows average very little above their neighbors in crop yields. Because the crops are good gives no indication of whether the cows are good or bad. On the average, there is practically no relation between the size of the farm and quality of the crops or cows. As a result we have all kinds of combinations of the factors of profits. There are very few farms that rank well in each of the four respects.

\section{Size of Business.}

Ways of Measuring Size.-There are many ways in which the size of the business may be measured. Farms may be compared on number of 
days of work done, number of men kept, amount of capital invested, number of cows or other animals kept, number of work animals, number of acres of lard, or acres of crops grown. So long as we are dealing with fairly uniform conditions, each of these comparisons will give about the same results, as an average of large numbers. But when a particular farm is considered, it may be placed in a different class when the method of sorting is changed.

Relation of Capital to Profits.--Tables 3, 4, 5 and 6 show the relation of capital to profits. The farmers in either of these counties who do not have a capital of at least $\$ 5000$, are not doing as well as hired men. In Tompkins County over one-third of the farmers had less than $\$ 4000$ capital, but not one of these made a labor income of $\$ 1000$. About twofifths of the men with $\$ 10,000$ capital made over $\$ 1000$ labor income. The figures for all the other regions show the same results.

Table 3.-Relation of Capital to Profits. 615 farms operated by owners, Tompkins County, New York.

\begin{tabular}{|c|c|c|}
\hline Capital. & $\begin{array}{c}\text { Number of } \\
\text { farms. }\end{array}$ & $\begin{array}{c}\text { Average } \\
\text { labor income. }\end{array}$ \\
\hline$\$ 2,000$ or less. . & . 36 & $\$ 192$ \\
\hline $2,001-4,000$ & 200 & 240 \\
\hline $4,001-6,000$ & 183 & 399 \\
\hline $6,001-8,000$ & 94 & 530 \\
\hline $8,001-10,000$. & 45 & 639 \\
\hline $10,001-15,000$. & 44 & 870 \\
\hline Over 15,000 & 13 & 1,164 \\
\hline
\end{tabular}

Table 4.-Relation of Capital to Profits. 615 farms operated by owners.

\begin{tabular}{|c|c|c|}
\hline Capital. & $\begin{array}{l}\text { Number of } \\
\text { farmers. }\end{array}$ & $\begin{array}{c}\text { farmers making } \\
\text { lahor incomes } \\
\text { of over } \$ 1000 \text {. }\end{array}$ \\
\hline$\$ 2,000$ or less. & $\ldots \quad 36$ & - 0 \\
\hline $2,001-4,000$ & 200 & 0 \\
\hline $4,001-6,000$ & . 183 & 8 \\
\hline $6,001-8,000$. & .. 94 & 14 \\
\hline $8,001-10,000$. & 45 & 22 \\
\hline $10,001-15,000$. & 44 & 32 \\
\hline Over 15,000 & 13 & 46 \\
\hline
\end{tabular}

Table 5.-Capital Related to Labor Income. 578 farms, Northern Livingston County, New York.

\begin{tabular}{|c|c|c|}
\hline Capital. & $\begin{array}{c}\text { Number of } \\
\text { farms. }\end{array}$ & $\begin{array}{c}\text { Average } \\
\text { labor income. }\end{array}$ \\
\hline 00 or less. & $\ldots 87$ & $\$ 291$ \\
\hline $01-7,500$. & .. 80 & 407 \\
\hline $01-10,000$. & . 112 & 480 \\
\hline $01-15,000$. & .. 164 & 769 \\
\hline $01-20,000$. & . 62 & 1,001 \\
\hline $01-30,000$. & 55 & 1,062 \\
\hline ver 30,000 . & 18 & 1,691 \\
\hline
\end{tabular}


Table 6.-Relation of Capital to Profits. 578 farms, Northern Livingston County, New York.

Per cent of the farmers making labor incomes

Capital. of over $\$ 1000$.

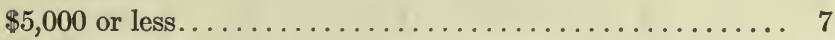

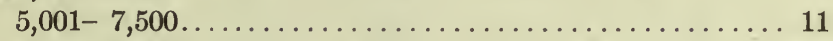

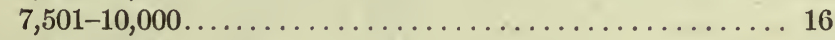

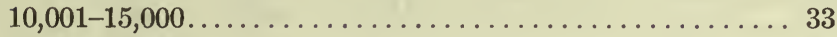

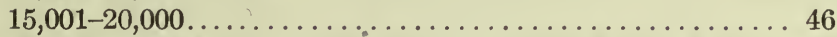

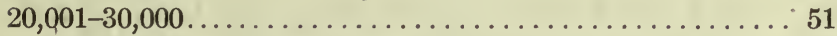

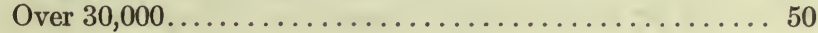

Relation of Amount of Labor Employed to Profits.-If we measure size of business by number of men or total value of labor directed, we find the same comparisons. Those farmers who do not direct at least one man besides themselves do not, on the average, earn much more than farm wages. Table 7 gives such a comparison for Tompkins County, New York. The total value of labor directed includes the farmer's labor estimated at $\$ 326$ for the year, this being the average price that farmers estimated it would cost to hire the labor done. If the total labor directed does not equal about $\$ 650$ to $\$ 700$, the farm does not employ one man for full time besides the farmer.

$\begin{array}{cc}\text { Table 7.- Relation of Labor to Profits. } \\ \begin{array}{c}\text { Value of } \\ \text { total labor }\end{array} \\ \$ 347 & \text { Labor income. } \\ 426 & 3288 \\ 557 & 332 \\ 730 & 532 \\ 960 & 721 \\ 1,307 & 1,194\end{array}$

Relation of Size of Farm to Profits.-A better measure of size of business is the acres farmed or better still the acres of crops grown. Tables 8 and 9 give such comparisons for general farming where hay, grain, potatoes, cabbage, apples are the usual crops and where a considerable proportion of the persons keep dairy cows.

Table 8.-Size of Farm Related to Profits. 586 farms, Tompkins County, New York.

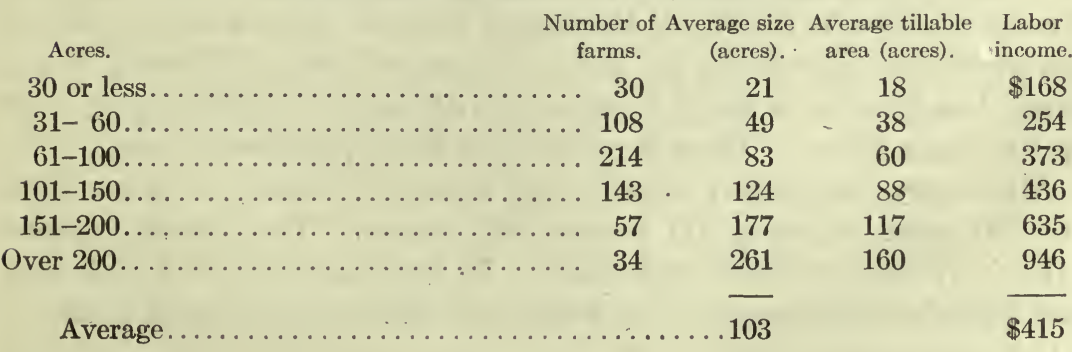


Table 9.-Size of Farm Related to Profits.

578 farms, Livingston County, New York.

\begin{tabular}{|c|c|c|c|c|}
\hline Acres farmed. & $\begin{array}{l}\text { Number of } \\
\text { farms. }\end{array}$ & $\begin{array}{l}\text { Average size } \\
\text { (acres). }\end{array}$ & $\begin{array}{l}\text { Tillable area } \\
\text { (acres). }\end{array}$ & $\begin{array}{r}\text { Labor } \\
\text { income. }\end{array}$ \\
\hline 30 or less. & $\ldots \quad 17$ & 20 & 17 & $\$ 54$ \\
\hline $31-50 \ldots$ & $\ldots \quad 35$ & 43 & 37 & 295 \\
\hline $51-100 \ldots$ & .. 147 & 79 & 64 & 437 \\
\hline $101-150 \ldots$ & ... 178 & 127 & 104 & 593 \\
\hline $151-200$. & $\begin{array}{l}\text {. } \quad 89 \\
\end{array}$ & 175 & 142 & 934 \\
\hline Over $200 \ldots$ & .. 112 & 305 & 241 & 1,082 \\
\hline
\end{tabular}

In these regions the average farmer with less than 50 acres would make more money if he sold his farm, loaned his money and hired out as a farm laborer, or better yet, be a tenant on a larger farm, or many of them might better go in debt for a large farm and own it.

Comparatively few farmers with less than 100 acres made very good profits. Of the 551 farmers who farmed 100 acres or less, only six made labor incomes of $\$ 1500$. But of 292 farmers who farmed over 150 acres, 60 made over $\$ 1500$.

Relation of Acres of Crops to Profits.-A still better way of measuring size is to compare the area of crops grown. This includes all harvested crops but does not include pasture. Table 10 gives such a comparison.

Table 10.-Relation of Acres of Crops to Labor Income.

\begin{tabular}{|c|c|c|c|}
\hline Acres of crops. & $\begin{array}{l}\text { Average } \\
\text { acres crops }\end{array}$ & $\begin{array}{c}\text { Number of } \\
\text { farm. }\end{array}$ & Labor income. \\
\hline 20 or less. . & $\ldots \quad 14$ & 18 & $\$ 24$ \\
\hline $21-40 \ldots$ & 31 & 55 & 257 \\
\hline $41-60 \ldots$ & 51 & 95 & 400 \\
\hline $61-80 \ldots$ & 69 & 115 & 481 \\
\hline $81-100 \ldots$ & $\ldots 90$ & 96 & 642 \\
\hline $101-140 \ldots \ldots$ & .. 118 & 112 & 937 \\
\hline Over $140 \ldots$ & . 193 & 88 & 1,261 \\
\hline
\end{tabular}

Most of the economics in production are dependent on the area of crops grown. Five horses can raise 100 to 125 acres of general farm crops when the crops consist of a good combination of grain, hay and potatoes, apples or cabbage. If the crops are of the above kinds, there should be at least 20 acres per horse, but if they are hay and grain, there should be at least 30 acres per horse. In the eastern states, the cost of horse labor per acre is more than the interest on the land. While five horses can raise 125 acres of crops, it is difficult to raise 50 acres of crops with two horses. Farm machinery is built on the 2, 3 and 4-horse basis. Evidently if one has less than 80 acres of crops, he must go without good machinery or must keep too many horses. There is no solution of the problem for him.

Machinery, horses and labor cannot be used efficiently with less than 80 to 100 acres of crops, 200 acres is still better. The various reasons for this have been published elsewhere. In this discussion, it is sufficient to see that size of business is very important and that crop acres is one of the best measures of size. 
The time spent in growing even an average crop in reasonable areas pays the highest wages of any farm work. If a farmer has a large area of crops, it not only indicates a good sized business, but indicates that the farmer is doing a large amount of work that pays well.

\section{Crop Yields.}

Increased yield per acre is important but not nearly so important as is usually assumed. Table 11 shows the relation of yield to labor income, when 100 per cent represents the average yield of the region.

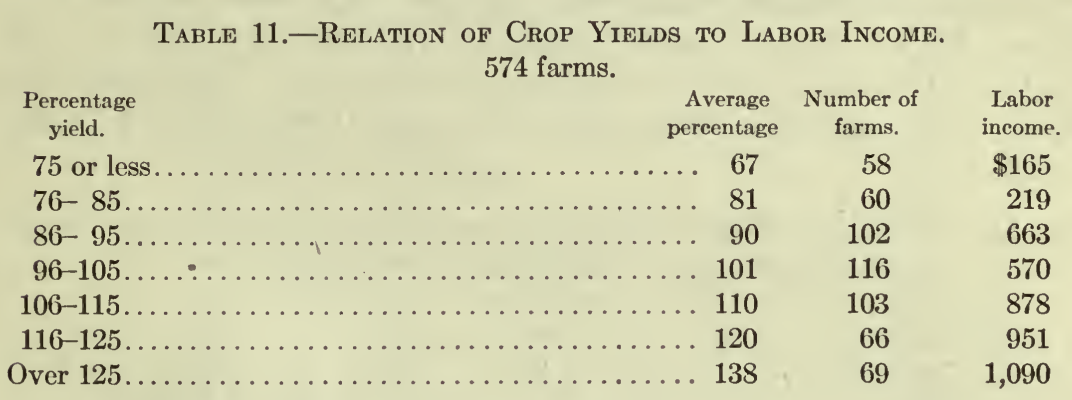

An increased yield per acre makes the business larger and if not carried too far is a good thing. After one secures yields of perhaps a fifth better than the neighbors on the same soil, he must be careful that his cost per bushel for the increased crop is not more than the crop is worth. If the neighbors on the same soil get one and a half tons of hay per acre, it may pay to grow two tons. If under these conditions one wishes three tons, it can usually be grown at less cost per ton on two acres than on one acre. This is the reason why the acres of crops have more influence on profits than does the yield per acre.

\section{Production Per Cow.}

All dairy products are produced on a very close margin of profit. It is very easy to feed cows so as to lose all that one has made by raising crops. Table 12 shows the relation of receipts per cow to profits. Those farmers who get over $\$ 75$ per cow are the only ones who are making good labor incomes. In this case, $\$ 75$ per cow indicates about 6000 pounds of milk.

Table 12.-Receifts per Cow Related to Profits, Tompkins County, NEW YORK.

\begin{tabular}{|c|c|c|}
\hline Receipts per cow. & $\begin{array}{c}\text { Number of } \\
\text { farms. }\end{array}$ & Labor income. \\
\hline$\$ 30$ or less. & $\ldots \quad 18$ & $\$ 30$ \\
\hline $31-50 \ldots$ & 97 & 316 \\
\hline $51-75 \ldots$ & $\ldots 106$ & 483 \\
\hline 76-100 $\ldots$ & $\ldots \quad 53$ & 715 \\
\hline Over $100 \ldots$ & 33 & 1,325 \\
\hline
\end{tabular}

It will be seen that farmers who get average crops are often doing very well but that it takes much better than average cows to pay. 


\section{Diversity.}

If a farmer raises nothing but crops, he usually wastes considerable material that could be used to a profit to feed animals. He is also likely to find it more difficult to keep men and horses busy all the year.

If he raises animals only, he spends all his time on the farm enterprise that is less likely to pay good wages. He does not get so much for his manure because a heavy application on one acre does not usually bring as good returns per ton as if spread on two acres. Nor is he so likely to keep horses and men fully employed. To care for a dozen cows is about half work for a man. A man will do this and raise the cows' feed and cash crops to sell besides. Table 13 shows such a comparison. The farmers who combine cash crops and stock make more than those who go to either extreme.

Table 13.-Diversified Farming Related to Profits on Farms Selling Wholesale Market Milk, Livingston County, New York.

\begin{tabular}{|c|c|c|c|}
\hline $\begin{array}{l}\text { Per cent of re- } \\
\text { ceipts from crops. }\end{array}$ & $\begin{array}{c}\text { Number of } \\
\text { farms. }\end{array}$ & $\begin{array}{c}\text { Average } \\
\text { area. }\end{array}$ & $\begin{array}{l}\text { Labor } \\
\text { income. }\end{array}$ \\
\hline 15 or less. . & $\ldots 14$ & 209 & $\$ 769$ \\
\hline $16-30 \ldots$ & 28 & 218 & 1,210 \\
\hline $31-50 \ldots$ & .. 25 & 264 & 1,284 \\
\hline Over $50 \ldots$. & $\ldots 10$ & 174 & 1,225 \\
\hline
\end{tabular}

Comparative Importance of Size, Crop Yields and Production Per Cow.

Table 14 shows that crop yields are less important than size of farm or production per cow. The combination of good cows and a large farm gives a better chance than good crops and good cows. The same point is shown by comparing Tables 11 and 12 .

Table 14.-Jefferson County.

Per cent making over $\$ 1000$

Labor income. labor income.
22

24

41

43

39

73

11 best cows and size................. 1,294

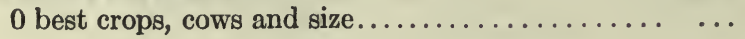

\section{Balanced Farms.}

As has been previously stated, there seems to be little relation between any of these factors. If a farmer is good in one respect, it does not tell anything about the other points.

Evidently a farmer who is as good as the average in every particular is a very far from an average man. He is a very unusual man. In Jefferson County, out of 670 farmers only 32 were as good as the average in each 
of the four respects. The average labor income of this region was $\$ 609$, but the farmers who were as good as the average in size (143 acres or more), crop yields, receipts per cow ( $\$ 59$ or more) and in diversity (20 per cent or more from crops) made an average of $\$ 1491$ and only 6 of them failed to make as much as $\$ 1000$.

As a standard for dairy farms, we may take the average of all farmers in three regions who sold market milk and who made labor incomes of $\$ 2000$ or more. Table 15 gives these averages.

Table 15.-Averages. 23 Farms Selling Wholesale Market Milk.

Three counties.

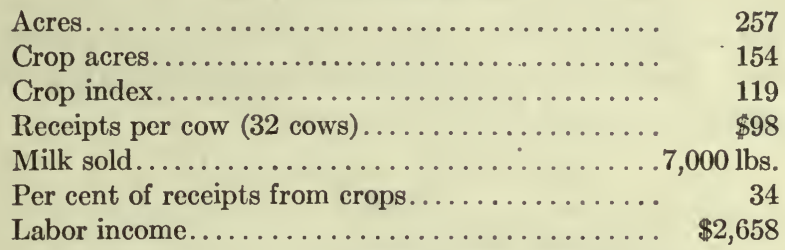

Our records give similar comparisons for other types of farming. But the principles of size and production hold on the truck farms and crop farms as well as on dairy farms.

\section{INDIVIDUAL FARMS.}

It is evident that we can give a very close estimate of labor income if we know the above four factors. The following examples are from Jefferson County:

\section{FARM 1.}

Crop acres, 29; very poor.

Crop index, 208; excellent.

Receipts per cow (11 cows), \$116; excellent.

Per cent of receipts from crops, 21; excellent.

Labor income, $\$ 980$.

This is the best record for so small an area. It represents the top notch in the "little farm well tilled." Splendid crops, splendid cows, even on the small area, crops to sell and all work done by the farmer himself with two months of hired labor. Such a farmer as this should be able to make $\$ 3000$ labor income if he rented land on which to grow 100 acres more crops, doubled his cows and kept two men by the year. With this system he would not have to work so hard.

FARM 2.

Crop acres, 21; very poor.

Crop index, 211; excellent. (Hay 3.3 T., silage 13 T.)

Receipts per cow (8 cows), $\$ 90$; excellent.

Per cent of receipts from crops, 22; excellent.

Hired labor, \$250; poor for the size.

Labor income, $\$ 380$.

This farmer kept poorer cows and hired one man although he had so little work to do. For these reasons, he made less than Farm No. 1. 


\section{FARM 3.}

Crop acres, 133; good.

Crop index, 75; poor. (Hay 1.1 T., oats 25 bu.)

Receipts per cow (20 cows), \$95; excellent.

Per cent of receipts from crops, 16; fair.

Labor income, $\$ 1,661$.

This farmer gets crops only three-fourths as good as his neighbors', but with the large area he should make a good profit from growing them. He sells part, and what he feeds to cows he makes a second profit on because he gets such good returns per cow.

We should expect him to do very well indeed. His crops are only one-third as good as Numbers 1 and 2, but the larger area more than makes up. If the soil is as good as his neighbors', he might readily bring his labor income to $\$ 2000$ by raising better crops.

FARM 4.

Crop acres, 110; excellent.

Crop index, 142; excellent.

Receipts per cow, $\$ 96$; excellent.

Per cent of receipts from crops, 19; excellent.

Labor income, $\$ 2,239$.

This farm is excellent in every particular. We should expect it to make at least $\$ 2000$, as it does. About the only difference from Number 3 is in crop yield.

\section{FARM 5.}

Crop acres, 109; excellent.

Crop index, 120; excellent.

Receipts per cow (32 cows), \$56; poor.

Per cent of receipts from crops, 4 ; poor.

Labor income, minus $\$ 113$.

This farmer made very good profit on his crops of which he had a good acreage. But he fed these crops to cows that did not pay their feed bill. If he had excellent cows, his labor income would be $\$ 1500$, but as it is he did not even make interest on his capital. He paid for the privilege of working.

\section{FARM 6.}

Crop acres, 259; excellent.

Crop index, 134; excellent.

Receipts per cow (33 cows), $\$ 74$; good.

Per cent of receipts from crops, 53; excellent.

Labor income, $\$ 3,270$.

This is the highest labor income made by any farmer who sold milk at wholesale. With his unusually large area of good crops, he could easily raise his labor income to $\$ 4000$ by keeping better cows.

After one has studied over large numbers of records it becomes possible to tell whether the labor income is poor, good, fair or excellent by 
knowing these few figures. This is the final proof that these are the most important factors of profits. This applies to other types of farming equally well. In about five cases out of one hundred, some other factor affects the results so decidedly as to make one guess wrong. But on most farms, a good sized area of crops and good yields have so strong an influence as to overshadow other factors and almost insure good returns if the crops are sold or are fed to animals that bring good returns.

There are some city men in the audience. I may say that all this discussion is from results by practical farmers. City persons are most likely to fail by putting too much money in buildings and by keeping too many men and by doing too many fancy things that are called scientific farming but that are really "folly farming." Experienced farmers do not often make serious mistakes on these things.

\section{A Farmers' Catechism.}

Each farmer will do well to compare his farm with successful farms to see where it is weak and then see if it can be improved.

Are there 80 to 200 acres of crops harvested? If not, can I buy or rent more land?

Are my crop yields 10 to 20 per cent better than my neighbors' who have the same soil? If not, will it not pay to improve them?

Are my cows at least 50 per cent better than my neighbors'? If not, how much am I losing on them per year? Had I best stop keeping cows or get better ones?

Am I getting at least 20 per cent of my receipts from the sale of cash crops? If not, could I make more by raising cash crops?

Am I getting at least 20 per cent of my money from animal products? If not, am I making good use of low grade farm products and am I and my horses kept well employed most of the year?

[Conference finally adjourned.] 

Appendix 


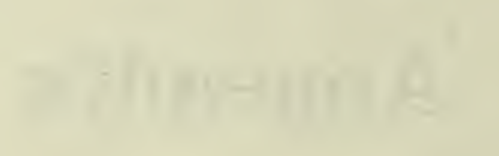


[Reprint of folder announcing Corn Contest]

FIRST CORN CONTEST

OF THE

CORN EXCHANGE NATIONAL BANK

Philadelphia

AT

COMMERCIAL EXCHANGE, PHILADELPHIA BOURSE

Dechmber 4, 5, 6, 1913

AT

PENNSỶLVANIA STATE COLLEGE OF AGRICULTURE State College, Pa.

December 29th to January 3D.

The American Bankers' Association has come to the conclusion that the most useful and profitable work they could undertake is along the line of agricultural development and education.

The Corn Exchange National Bank of Philadelphia has always been closely associated with the Grain Exchange (now called the Commercial Exchange). So we are in hearty sympathy with the movement and believe that better crops will mean increased prosperity to all.

On these broad lines we enlist the co-operation of all banks, newspapers, business men and educators in the four States-Pennsylvania, New Jersey, Delaware and Maryland.

\section{$\$ 1,250$ IN PRIZES}

for the best corn grown during 1913 in Pennsylvania, New Jersey, Delaware, Maryland, will be given by the

Corn Exchange National Bank, Philadelphia.

Judges to be one representative each from the State Agricultural Colleges of Pennsylvania, New Jersey, Delaware, Maryland and the Commercial (Grain) Exchange, Bourse, Philadelphia.

The Following Rules Will Govern the Contest.

1. Entries to consist of not less than ten (10) ears of corn.

2. All exhibits to be grown by exhibitors within the States of Pennsylvania, New Jersey, Delaware and Maryland, during the season of 1913.

3. Contest open to all competitors.

4. All general entries must be from fields of one acre or more. Entries for boys' prizes alone may be grown in fields of not less than one-quarter acre. Boys may compete for general prizes if corn is grown in fields of one acre and over. 
[Reprint of folder announcing Corn Contest]

5. Competitors may compete in all lots, but may make but one entry in each lot.

6. Exhibits must be delivered at Corn Exchange National Bank, Second and Chestnut Streets, Philadelphia, Pa., not later than December 1, 1913. If shipped by freight or express, charges must be prepaid.

7. Each exhibit must be accompanied by instructions, giving name and address of exhibitor, together with name of class it is desired to enter.

8. Packages will be opened and marked by representatives from Pennsylvania State College.

9. Corn will be exhibited at Commercial Exchange, Philadelphia Bourse, on December 4, 5 and 6, 1913, and during Farmers' Week at Pennsylvania State College, State College, Pa., from December 29th to January $3 d$.

10. With the exception of a few specimens, which the bank desires for exhibition during the year, upon request of the grower, the corn will be returned by express (charges collect) to be used for seed.

\section{SWEEPSTAKE PRIZES.}

\section{Four States.}

Pennsylvania, New Jersey, Delaware and Maryland. All entries grown in fields not less than one acre compete for this prize, but prize winners will be withdrawn from competition in their regular classes.

DENT CLASS.

First prize.....\$100.00 Second prize... \$50.00

Third prize........ \$25.00

\section{PENNSYLVANIA.}

District No. 1.

Comprising Erie, Crawford, Warren, Mercer, Lawrence, Tioga, Bradford, Susquehanna, Wayne, Sullivan Wyoming, Lackawanna, Pike, Monroe, McKean, Potter, Venango, Forest, Elk, Cameron, Clarion, Jefferson, Butler, Armstrong, Indiana, Clearfield and Cambria Counties.

\section{CLASSES OF CORN. \\ Yellow Dent.}

First prize......\$20.00 Second prize.... \$10.00 Third prize....... $\$ 5.00$

\section{White Dent.}

First prize......\$20.00 Second prize ... \$10.00 
[Reprint of folder announcing Corn Contest]

White Cap Yellow Dent.

First prize......\$20.00 Second prize.... \$10.00

Third prize........ \$5.00

Flint.

First prize.....\$20.00 Second prize... \$10.00 Third prize....... $\$ 5.00$

District No. 2.

Comprising Beaver, Allegheny, Westmoreland, Washington, Greene, Fayette, Somerset, Clinton, Lycoming, Center, Union Montour, Columbia, Luzerne, Blair, Huntingdon, Mifflin, Snyder, Northumberland, Schuylkill, Carbon, Juniata, Perry, Dauphin, Bedford and Fulton Counties.

Same classes and same number and amount of prizes as in District No. 1.

\section{District No. 3.}

Comprising Franklin, Cumberland, Lebanon, Berks, Lehigh, Northampton, Adams, York, Lancaster, Chester, Montgomery, Bucks, Delaware, and Philadelphia Counties.

CLASSES OF CORN.

Yellow Dent.

First prize......\$20.00 Second prize....\$10.00

Third prize....... \$5.00

White Dent.

First prize.....\$20.00 Second prize....\$10.00 Third prize....... $\$ 5.00$

White Cap Yellow Dent.

First prize..... \$20.00 Second prize....\$10.00

Third prize....... \$5.00

\section{DELAWARE.}

From the State at large.

CLASSES OF CORN.

White.

First prize......\$20.00 Third prize .... \$10.00

Second prize..... $15.00 \quad$ Fourth prize.... 5.00 
[Reprint of folder announcing Corn Contest]

Yellow.

First prize..... \$20.00 Third prize.. . . \$10.00

Second prize.... 15.00 Fourth prize.... 5.00

MIXED CORN.

First prize.....\$20.00 Third prize.... \$10.00

Second prize..... $15.00 \quad$ Fourth prize.... 5.00

\section{MARYLAND.}

Same classes and same number and amount of Prizes as Delaware.

\section{NEW JERSEY.}

South Jersey District comprising Middlesex, Mercer, Monmouth, Burlington, Ocean, Camden, Gloucester, Salem, Cumberland, Atlantic, Cape May.

\section{CLASSES OF CORN.}

White.

First prize.....\$20.00 Third prize . . . \$10.00

Second prize..... 15.00 Fourth prize.... 5.00

Yellow.

First prize..... \$20.00 Third prize....\$10.00

Second prize..... 15.00 Fourth prize.... 5.00

North Jersey District comprising Somerset, Hunterdon, Union, Warren, Morris, Essex, Hudson, Bergen, Passaic, Sussex.

North Jersey District same classes and same number and amount of prizes as in South Jersey District.

\section{BOYS' PRIZES.}

PENNSYLVANIA.

Boys' (under 21) Prizes.

Corn grown in fields not less than $\frac{1}{4}$ acre.

\section{Dent.}

First prize..... \$20.00 Third prize .... \$5.00

Second prize..... 10.00 Fourth prize.... 3.00

\section{Flint.}

First prize. . . . $\$ 20.00$ Third prize .... $\$ \$ 5.00$

Second prize..... 10.00 Fourth prize.... 3.00 
[Reprint of folder announcing Corn Contest]

NEW JERSEY.

Boys' (under 21) Prizes.

Corn grown in fields not less than $\frac{1}{4}$ acre.

Dent.

First prize......\$20.00 Third prize.... \$5.00

Second prize..... 10.00 Fourth prize.... 3.00

DELAWARE.

Same conditions, same kind of prize as New Jersey.

MARYLAND.

Same conditions and same kind of prizes as New Jersey.

\section{CORN}

\section{From Pennsyluania State College Bulletin.}

More care should be exercised in purchasing seed corn. There are many different corn sections in Pennsylvania, and seed adapted to one section may not do well in another section; therefore, seed corn in large quantity should not be purchased from other parts of the State or from other States where the conditions are entirely different. Tests may be made of small amounts of seed of promising varieties and strains before they are extensively planted.

A plat of four rows $3 \frac{1}{2}$ feet apart and each containing 42 hills 3 feet apart will make approximately 1-25 acre. Six kernels should be planted to hill and thinned to three stalks. Varieties thus planted will mix and must not be used for seed.

Corn Improvement.-The foundation stock must be improved first. Two methods are in common use for doing this: (1) The use of a selected seed plat. (2) Ear row tests. All seed corn should be carefully selected in the field on the stock or purchased on the ear. A germination test should be made in the spring before planting and all ears rejected which do not germinate 100 per cent. Germination may best be done in boxes about 3 inches deep. Fill the box with sand and divide it into squares of about 2 inches each. Saturate sand thoroughly with water. Arrange the ears in rows and number them. Take six kernels, 2 each from near butt, from the center and from near tip of the ear and place them in the moist sand in regular order. Cover the box with a pane of glass and keep at temperature of living room. 


\section{[Reprint folder announcing Corn Contest]}

1. The selected seed plat. This consists of a plat of ground isolated from all other corn, at least fifty rods, if possible and large enough to grow the quantity of seed desired. Select a few of the very best seed ears and shell together for this plat. During growing season, cut out all barren, dwarfed and diseased stalks before they have produced any pollen (before tasseling). For the second year, the very best ears from above may be used for another plat, etc.

2. Ear to row method. This method is the best for improving corn rapidly and for getting the very best results, but it requires careful work and much of it. The general plan is to select 100 of the best ears from the variety to be improved and number each ear securely. Shell half of each ear and plant it in a row numbered to correspond. (By planting in rows $3 \frac{1}{2}$ feet apart and 42 hills, 3 feet apart to the row, each row will contain approximately 1-100 of an acre). Six grains should be planted to a hill and stand thinned to three stalks. These rows should be studied during the growing season, and all the desirable features which they develop should be noted down for reference. At harvesting time each row should be harvested separately and weighed. The best ears from ten of the very best of these rows should be selected for field planting. By shelling together the remainder of these same parent ears and planting in an increase plat the following year, provision may be made for selecting good ears for the next year's row tests. All row plats should be isolated, as described above. This plan provides for a succession of seed plat and row test on alternate years (this test may also be conducted in a co-operative way or by one farmer in each community, who will supply seed to his neighbor). If carefully followed, the improved seed which it will yield will well repay the time and money involved. There is at present a great demand for improved seed corn in all parts of Pennsylvania.

Care of Seed.- Seed corn should be carefully dried and stored in a warm, dry and well-ventilated place. A wire cage in a warm attic makes an ideal storage place. 
[Reprint of "folder" sent out by the Corn Exchange National Bank of Philadelphia for their Corn Contest]

SUGGESTIONS ON SELECTING CORN FOR EXHIBITION.

FIRST CORN CONTEST

OF THE

CORN EXCHANGE NATIONAL BANK OF PHILADEI,PHIA,

December 4, 5 and 6, 1913.

\section{SUGGESTIONS ON SELECTING CORN FOR EXHIBITION.}

By Prof. A. E. Granthan,

Delaware College Agricultural Experiment Station.

Before selecting corn for an exhibit, study the requirements of the score card, in order to have a definite idea of the characteristics of a good ear. The next thing to do is to select an ear of corn which is most nearly like the idea in mind. Then pick out a considerable number of ears which approach the ideal ear. From this number select the number, ten or twenty as the case may be, for the exhibit. One of the most important points to consider in selecting an exhibit is the uniformity of the ears. In other words, all the ears of the exhibit should look alike. In corn breeding as well as in animal breeding, results will be most rapidly accomplished only when particular types are developed. Thus each exhibit should present a definite type. - It is not so important what this type is, provided it has the characteristics of good corn, but care should be taken to have the exhibit represent some type. For this reason the ears exhibited should have, as nearly as possible, the same length, the same diameter, the same shade of color, the same character of indentation, the same size, width and shape of kernel, and the same sort of butts, tips and cobs. See that the ears are sound, mature, free from injury, and that kernels are not shelled off.

\section{DIRECTIONS FOR USING SCORE CARD.}

\section{UNIFORMITY OF EXHIBIT [15].}

The ears of an exhibit should be uniform in size, color and indentation. Judge the exhibit separately for each of these characters. The 15 points will allow 5 to be given to size, 5 to color, and 5 to indentation; or, in other words, each ear will be allowed $\frac{1}{2}$ point under each of these heads. For each ear that varies in the above characters, cut from $\frac{1}{4}$ to $\frac{1}{2}$ point each. Add these cuts together for total cut of uniformity of exhibit. 
[Reprint of "folder" sent out by the Corn Exchange National Bank of Philadelphia for their Corn Contest]

\section{Maturity and Market Condition [15].}

Ears should be firm and free from injury or decay spots. The firmness of the ear is best determined by twisting in the hand or by moving the kernels with the thumb. Cut not to exceed $1 \frac{1}{2}$ points for each ear that is defective.

\section{Purity (as Shown by Color) of Kernel [5].}

Kernels should be free from mixture of corn of opposite color. In yellow corn the mixture is shown on the caps of the kernels, in white corn on the sides. For each kernel in an ear showing such mixture cut $\frac{1}{4}$ point, except in mixed corn, where this does not apply.

\section{Purity (as Shown by Color) of Cob [5].}

Cobs should be of one color; in yellow corn they are usually red; in white corn, white. For each cob opposite in color to the prevailing type cut 2 points. For pink cobs cut $\frac{1}{4}$ to $\frac{1}{2}$ point, according to shade or color. Two cobs of opposite color shall bar the exhibit.

\section{Shape of Ear [10].}

The shape should approach the cylindrical, which indicates that depth of kernel is maintained from butt to tip. A cylindrical ear usually means a greater per cent of corn to cob, and a larger number of kernels of uniform size and shape for planting. Cut $\frac{1}{4}$ to 1 point for each ear that tapers too greatly.

\section{Proportion of Length to Circumference [10].}

The ratio of circumference to length should be approximately as 3 to 4 , or the circumference measured at a point one-third of the distance from butt to tip should be three-fourths of the length. A ten-inch ear should be approximately seven and one-half inches in circumference. Cut not to exceed 1 point for each ear.

\section{Shape And Uniformtty of Kernels [10].}

The kernels should be uniform in size and shape. They should be slightly wedge-shape with straight edges so as to fit tightly together, but should be pointed. Remove three kernels from each ear for comparison. Cut $\frac{1}{4}$ to 1 point for each ear with poor kernels.

\section{Butts [5].}

The butts should be well-rounded out with deep regular kernels, solidly compacted together around a clean cup-shaped cavity. The 
[Reprint of "folder" sent out by the Corn Exchange National Bank of Philadelphia for their Corn Contest]

shank should be medium in size, so as not to be difficult to break off when husking. Cut not to exceed $\frac{1}{2}$ point for each badly formed butt.

\section{TIPS [5].}

Deep kernels shall fill out the end of the ear in as regular rows as possible. The ideal tip is completely covered, but if the kernels are deep and regular out even to the end of the cob, no cut need be given.

\section{Space Between Rows [5].}

Furrow between rows, should be narrow, with the kernels fitting closely together at the cob, but not crowded. Cut not to exceed $\frac{1}{2}$ point for each ear.

\section{Proportion of Corn to Ear [15].}

The proportion of corn to ear should be not less than 85 per cent. The per cent is best determined by shelling and weighing representative ears. It can be estimated by taking into account the depth and shape of kernel, the filling out of butt and tips, the size of cob and degree of maturity. Cut $1 \frac{1}{2}$ points for each per cent the exhibit falls below 85 per cent.

\section{SCORE CARD.}

Uniformity of Exhibit................ 15

Maturity and market condition............. 15

Purity (as shown by color) of cob.......... 5

Purity (as shown by color) of kernel.......... 5

Shape of ear.................. 10

Proportion of length to circumference.......... 10

Shape and uniformity of kernel............ 10

Butts.......................... 5

Tips............................. 5

Space between rows.................. 5

Proportion of corn to ear................. 15 
[Reprint of Stationery.]

CORN EXCHANGE NATIONAL BANK.

Corn Show and Agricultural Conference.

Bourse Building; Thursday, Friday, Saturday, December 4, 5, 6, 1913.

Assisted by

The Commercial Exchange

Philadelphia

The University of Pennsylvania

State College of Pennsylvania

Pennsylvania Rural Progress Ass'n

City Club of Philadelphia

Philadelphia Society for Promoting Agriculture

C. S. Calwell, Chairman

President Corn Exchange National Bank

Clarence Sears Kates

Chairman of the Joint Committee

Pennsylvania Rural Progress Association

Vice-Chairmen

Antonio SANS

President Commercial Exchange

ROBERT C. WRIGHT

F. T. M., Pennsylvania Railroad Co.

WALTER HoRstManN

Vice-President Chamber of Commerce

D. T. Fleisher

Pres., Merchants \& Manufacturers Ass'n

WM. M. COATES

President Board of Trade

HarRy Nusbaum

Pres. Philadelphia Produce Exchange

Clarence Sears Kates

Pennsylvania Rural Progress Ass'n

Charles Z. Tryon

Hardware Merchants \& Manuf'rs Ass'n

J. BERTRAM LIPPINCOTT

Philadelphia Society for the Promotion of Agriculture

EDGAR FAHS SMITH

Provost University of Pennsylvania

N. B. KeLLy, Treasurer

Secretary Chamber of Commerce

D. W. Summerfield, Secretary

9 North Thirteenth Street

Sec'y Merchants \& Manufacturers Ass'n

Manager of the Conference

MrS. Edith EllicotT SMith

President Penna. Rural Progress Ass'n

P. O. Box 1905 


\section{PRIZES AWARDED IN CORN CONTEST.}

The following prize winners were announced today by the judges in the Corn Contest conducted by the Corn Exchange National Bank the past season, the entries in which comprised the exhibits in the Corn Show held in the Philadelphia Bourse Thursday, Friday and Saturday. The contest was open to farmers of Pennsylvania, New Jersey, Delaware and Maryland, and was for the best ten ears of corn grown on an acre or more of ground this year. Ninety-six separate prizes were offered, ranging from $\$ 3$ to $\$ 100$, and totaling $\$ 1,250$. The judges were: Samuel L. McKnight, representing the Commercial Exchange; Professor F. D. Gardner, Pennsylvania State College; Professor L. N. Merrill, New Jersey Agricultural Experiment Station; A. E. Grantham, Delaware State College; and Nicholas Schmitz, Maryland Agricultural College.

\section{SWEEPSTAKES.}

First prize......\$100............ D. Radebaugh, Bynum, Md.

Second prize..... $50 \ldots \ldots \ldots \ldots$ Clarence A. Mellinger, Ronks, Pa.

Third prize..... $\quad 25 \ldots \ldots \ldots \ldots \ldots$ James T. Shallcross, Middletown, Del.

Special Prizes for Ohio Boys.

First prize...... $\$ 25 \ldots \ldots \ldots \ldots \ldots$ William C. Kirk, Jeffersonville, Ohio

Second prize..... 20.......... Jay Lawrence, Coshocton, Ohio

Third prize..... $15 \ldots \ldots \ldots \ldots$ Howard C. Vannorsdall, Jeffersonville, Ohio

Fourth prize......

$10 \ldots \ldots \ldots \ldots$ Walter S. Blamer, Johnstown, Ohio

\section{Pennsyluania.}

First District.

Yellow Dent, First prize.... $\$ 20 \ldots \ldots \ldots$ Arthur F. Hickok, Troy, Pa.

Yellow Dent, Second prize... 10......... K. Sloan, Canton, Pa.

Yellow Dent, Third prize.... $5 \ldots \ldots \ldots$ Jacob Gorley, Everette, Pa.

White Cap Yellow Dent, First prize. . \$20 ..... Edgar M. Wilkinson, Erie, Pa.

Flint, First prize........ $\$ 20 \ldots \ldots \ldots$. K. Sloan, Canton, Pa.

Second District.

Yellow Dent, First prize.....\$20......... Sylvester S. Sheller, Duncannon, Pa.

Yellow Dent, Second prize... $10 \ldots \ldots$. . Wallace Haberman, Andreas, Pa.

Yellow Dent, Third prize.... 5

White Cap Yellow Dent, First prize. .\$20..... William Claney, Antes Fort, Pa.

Flint, First prize....... $\$ 20 \ldots \ldots \ldots$ Wallace Haberman, Andreas, Pa. 
Third District.

Yellow Dent, First prize.... $\$ 20 \ldots \ldots \ldots$. A. and T. Crowell, Avondale, Pa.

Yellow Dent, Second prize... $10 \ldots \ldots \ldots$. . . Ad. Alexander, Unionville, Pa.

Yellow Dent, Third prize.... $5 \ldots \ldots \ldots$. Henry Palmer, Avondale, Pa.

White Dent, First prize..... \$20........ Ben. Harris, Newtown, Pa.

White Dent, Second prize.... 10........Joseph Briggs, Yardley, Pa.

White Dent, Third prize.... $5 \ldots \ldots \ldots \ldots$. W. Burkhart \& Son, Lititz, Pa.

White Cap Yellow Dent, First prize. . . \$20 . . . Harry B. Herr, Lancaster, Pa.

White Cap Yellow Dent, Second prize. . 10... David M. Landis, Lancaster, Pa.

White Cap Yellow Dent, Third prize... 5 ....G. W. and C. A. Row, Yardley, Pa.

Delaware.

White Dent, First prize..... \$20........Naudain \& Son, Marshallton, Del.

White Dent, Second prize.... $15 \ldots \ldots \ldots$. . . S. Whittock, Middletown, Del.

White Dent, Third prize.... $10 \ldots \ldots \ldots$ Harvey Ball, Stanton, Del.

White Dent, Fourth prize.... $5 \ldots \ldots \ldots$ Horace A. Dilworth, Montchanin, Del.

Yellow Dent, First prize.... $\$ 20 \ldots \ldots \ldots$ Naudain \& Son, Marshallton, Del.

Yellow Dent, Second prize... $15 \ldots \ldots \ldots$. . . . Horace A. Dilworth, Montchanin, Del.

Yellow Dent, Third prize.... $10 \ldots \ldots \ldots$. A. S. Whittock, Middletown, Del.

Yellow Dent, Fourth prize... $5 \ldots \ldots \ldots \ldots$. H. Shaeffer, New Castle, Del.

Mixed Corn, First prize..... $\$ 20 \ldots \ldots \ldots$ Naudain \& Son, Marshallton, Del.

Mixed Corn, Second prize.... 15.........Harvey Ball, Stanton, Del.

Mixed Corn, Third prize.... $10 \ldots \ldots \ldots \ldots$ Horace A. Dillworth, Montchanin, Del.

Mixed Corn, Fourth prize.... $5 \ldots \ldots \ldots$ Harvey Walker, Marshallton, Del.

\section{MARYLAND.}

White Dent, First prize..... \$20........ Josiah Massey, Chestertown, Md.

White Dent, Second prize.... $15 \ldots \ldots \ldots$. . . L. Tucker, Forest Hill, Md.

White Dent, Third prize.... 10........ B. Twining, Forest Hill, Md.

White Dent, Fourth prize.... $5 \ldots . \ldots \ldots$. Oakland Farm, Havre de Grace, Md.

Yellow Dent, First prize.... $\$ 20 \ldots \ldots \ldots$. . . B. Twining, Forest Hill, Md.

Yellow Dent, Second prize... $15 \ldots \ldots \ldots$. . . . . . . . . . . . . Farm, Havre de Grace, Md.

Yellow Dent, Third prize.... $10 \ldots . \ldots \ldots$ James R. Galbraith, Street P. O., Md.

Yellow Dent, Fourth prize... $5 \ldots \ldots \ldots \ldots$ Jas. B. Clarke, Ellicott City, Md.

Mixed Corn, First prize..... $\$ 20 \ldots \ldots \ldots \ldots$ John L. Stevens, Rising Sun, Md.

Mixed Corn, Second prize.... 15........W. Irving Walker, Chestertown, Md.

Mixed Corn, Third prize.... 10........ Bohemia Hill Farm, Earlville, Md.

New Jersey.

South District.

White Corn, First prize..... $\$ 20 \ldots \ldots \ldots \ldots$ Minch Bros., Bridgeton, N. J.

White Corn, Second prize.... $15 \ldots \ldots \ldots$ Clarence H. Fogg, Bridgeton, N. J.

White Corn, Third prize.... 10.........Allen Ackley, Bridgeton, N. J.

White Corn, Fourth prize.... $5 \ldots \ldots \ldots$ Maurice Vennell, Marlton, N. J.

Yellow Dent, First prize......

Yellow Dent, Second prize....

Yellow Dent, Third prize..... $\$ 20 \ldots \ldots$. . . Henry S. Lippincott, Marlton, N. J.

Yellow Dent, Fourth prize....

$15 \ldots \ldots \ldots$. . . B. Wander, Bridgeton, N. J.

$10 \ldots . \ldots$. C. H. Pew, Mount Holly, N. J.

$5 \ldots \ldots \ldots$ Wilmer Collins, Merchantville, N. J. 
Mixed Corn, First prize..... $\$ 20 \ldots \ldots \ldots$ George Sharp, Bridgeton, N. J.

Mixed Corn, Second prize.... 15........William Sherman, Mount Holly, N. J.

Mixed Corn, Third prize.... 10........ Thomas A. Gracey, Burlington, N. J.

Mixed Corn, Fourth prize.... $5 \ldots \ldots \ldots$. Charles Scott, Sewell, N. J.

\section{Boys' Prizes.}

Pennsylvania.

Dent Corn, First prize......\$20........Fred Coates, Cochranville, Pa.

Dent Corn, Second prize.... 10......... Fred Frick, Pine Forge, Pa.

Dent Corn, Third prize...... $5 \ldots \ldots \ldots$ Albert O. Bruckart, Lititz, Pa.

Dent Corn, Fourth prize.... $3 \ldots \ldots \ldots$ Aldon A. Wilson, Newtown, Pa.

Flint Corn, First prize . . . . 20........ Clarence Small, Bethlehem, Pa. (Single entry.)

\section{New Jersey.}

Dent Corn, First prize......\$20.......Raymond Harris, Deerfield, N. J.

Dent Corn, Second prize..... 10......... Basil Sholl, Burlington, N. J.

Dent Corn, Third prize..... $5 \ldots \ldots \ldots$. . . . . . Darry A. Drew, Vernon, N. J.

Dent Corn, Fourth prize..... $3 \ldots \ldots \ldots$. Howard E. Wills, Marlton, N. J.

Maryland.

Dent Corn, First prize......\$20........Geo. W. Radebaugh, Bynum, Md.

Dent Corn, Second prize..... 10......... Russell Galbraith, Street P. O., Md.

Dent Corn, Third prize..... $5 \ldots \ldots \ldots$. Edward Ady, Sharon, Md. 
Report on Potato Embargo Considered at a Hearing Conducted by the Special Commission of the Department of Agriculture, Held in Washington, December 18, 1913.

By Clarence Sears Kates, Delegate.

The hearing was held for the purpose of discussing whether it is possible to safeguard this country from known foreign potato diseases which have been inspected and pronounced free from infestation by foreign experts.

If deemed feasible, this would be accomplished by placing the potato under the plant quarantine act, which now governs nursery stock only. Otherwise, the alternatives either to exclude them absolutely by quarantine or to allow their free entry without any supervision or inspection to guard against disease. Also, to add to the potato diseases already under ban the new disease known as Powdery Smut.

Those in attendance were delegates from all of the potato growing states-Maine, Massachusetts, New York, Pennsylvania, Delaware, Maryland, Virginia, Minnesota, Wisconsin, Michigan, Idaho, Coloradomade up of pathologists, farmers, commission men and consumers; also Senators and members of Congress from a number of these states.

The foreign governments of Ireland, Scotland, England and Dominion of Canada (as well as the nation of Great Britain), Holland and Belgium, were each represented by delegates specially sent to this country for attendance at this hearing. This shows the great importance of the question involved.

The United States Government, through the Commission, made it clear at the outset that no consideration of the economic effect of the decision could be considered. It was in the same category as the establishment of a quarantine against the human disease of small-pox. The point to establish is-Is there a disease? If so, is it infectious? If infectious, is it a menace? If a menace, how shall this country guard against its spread?

It was established to all present at this hearing that all the above features were proved. Also, that the disease existed in the Dominion of Canada, Newfoundland, Ireland and Scotland, and the continent of Europe. This was proven from the printed reports of the pathologists of the respective countries, and that there was no known preventive or cure of the new disease of Powdery Scab. The United States inspectors had noted the old disease of "potato scab" or "black wart" and the new one of "powdery scab" in almost all of the importations examined at the docks where potatoes enter and consisting of a very large percentage. 
It was claimed that the fact of foreign potatoes not being used for seed did not mitigate the danger. The menace existed from the parings being used in the refuse fed to animals both in city and country, and the resultant manure infects the soil.

Colorado showed that in one district of that state the entire potato industry was destroyed through the introduction of an infectious disease. It was also stated by pathologists that whereas the diseases would be in a mild form in one area, the introduction to another area had been known to cause a virulent form to develop.

The loss on the crops in the infected areas, of which there are already a number in the United States, amounts to one-third to one-half the value of non-infected areas. And the potatoes themselves are a loss to the consumer.

The foreign representatives' statements were devoted to minimizing the virulence of the diseases and also that there were but few areas infected and that it would be confined to those areas, which would be, they claimed, a simple matter. That new bags only would be used, inspection and certification of the most ample and satisfactory kind would be furnished, etc.

I was present throughout the entire hearing, with the exception of about fifteen minutes-the session lasted from $10 \mathrm{~A}$. M. to 12.50 Р. м. and $2.30 \mathrm{P}$. M. to $5.30 \mathrm{P.}$ м. My belief is four individuals (other than the foreign delegates) expressed any sentiment but that the most stringent quarantine should be established-resulting in absolute prohibition of entry within our borders. It was also indicated that even though this prohibited Canada importations into United States, the Dominion Government (though advocating admission from Great Britain and the Continent on foreign certificate of freedom from infection) would feel impelled to. take the same protective steps as the United States. Of the four Americans who did not concur, two thought that a foreign certificate would probably accomplish sufficient protection. And two others (members of Congress, one from Pennsylvania and one from New York) pleaded for general admission on the basis of competition lowering the price. Of course, the decision of the Commission was reserved, and no indication of time they would give the decision was given.

From time to time the economic results of the quarantine were introduced. In that relation the statement was made that the crop for 1913 was for a ten year average, twelve million bushels above normal. The crop for 1913 amounted to 331 million bushels. The per capita consumption lies between three to four bushels. The largest importation ever received was thirteen million bushels. The claim of a shortage this year is due to the comparison with the abnormal crop of 1912 . 
[Reprint of decision in re Potato quarantine.]

\title{
UNITED STATES DEPARTMENT OF AGRICULTURE,
}

\author{
OfFice of the Secretary.
}

Federal Horticultural Board.

Notice of Quarantine No. 11 (Foreign).

\section{Potato Quarantine.}

The fact has been determined by the Secretary of Agriculture that injurious potato diseases, including the powdery scab (Spongospora subterranea), new to and not heretofore widely prevalent or distributed within and throughout the United States, exist in the Dominion of Canada, Newfoundland, the islands of St. Pierre and Miquelon, Great Britain, Ireland, and Continental Europe, and are coming to the United States with imported potatoes.

Now, therefore, I, David F. Houston, Secretary of Agriculture, under the authority conferred by section 7 of the act of Congress approved August 20, 1912, known as "The Plant Quarantine Act" (37 United States Statutes at Large, page 315), do hereby declare that it is necessary, in order to prevent the introduction into the United States of such potato diseases, to forbid the importation into the United States, from the countries hereinbefore named, of the common or Irish potato (Solanum tuberosum) until such time as it shall have been ascertained, to the satisfaction of the Secretary of Agriculture, that the country or locality from which potatoes are offered for import is free from such potato diseases.

On and after December 24, 1913, and until further notice, by virtue of said section 7 of the act of Congress approved August 20, 1912, the importation, from the countries hereinbefore named, of the common or Irish potato, except for experimental or scientific purposes by the Department of Agriculture, is prohibited: Provided, That shipments of such potatoes loaded prior to December 24, 1913, as shown by consular invoices, will be permitted entry up to and including January 15, 1914.

Done at Washington this 22d day of December, 1913.

Witness my hand and the seal of the United States Department of Agriculture.

David F. Houston, Secretary of Agriculture.

[For further "Notices," Amendments, etc., on this topic apply to the Federal Horticultural Board, U. S. Dept. Agric., Washington, D. C.] 
[Announcing the formation of the Philadelphia Agricultural Service Bureau, names of the Committee and scope of the work.]

\section{STATEMENT.}

\section{By Charles S. Calwell,}

President, Corn Exchange National Bank, Philadelphia.

At the Agricultural Conference, which was held in Philadelphia City Hall, in December, I was asked to appoint a committee to establish an Agricultural Service Bureau, to act as a clearing-house for agricultural information and to establish mutually advantageous relations between the farmer and the Philadelphia market. After giving the matter very careful consideration, I have appointed the following gentlemen: Robert C. Wright, A. B. Ross, Clarence Sears Kates, Edward T. Butterworth, John P. Connelly, Louis Graff, George W. Norris, Charles S. Calwell.

This committee will work in close harmony with the State College of Pennsylvania, the Experiment Stations of New Jersey, Delaware and Maryland, also the U. S. Department of Agriculture.

The objects of the committee and its personnel have received the hearty approval of the Mayor and the Administration in general.

Mr. Wright is Freight Traffic Manager of the Pennsylvania Railroad Company, was formerly General Freight Agent of the Pennsylvania Railroad Company, and is very much interested in the development of agriculture along the Pennsylvania Railroad lines.

Mr. A. B. Ross is County Agent of Bedford County, Pa., United States Department of Agriculture. His work has attracted national attention, and the Government at Washington, after investigating his work in Bedford County, decided to use his work as a basis for county agents' work throughout the United States, and now has in course of preparation a Farmers' Bulletin describing the work that has been accomplished in that county.

Mr. Edward T. Butterworth is in the commission produce business on Dock street. $\mathrm{He}$ is president of the Philadelphia Branch of the National League of Commission Merchants of the United States. He has been of great help to the farmers in teaching them how to pack their produce for shipment into the Philadelphia market. He is an expert in his line, and will keep the Bureau in close touch with the commission trade, so that practical information can be given to the farmer as to the standardization needs and requirements for growing, packing and shipping to Philadelphia. 
John P. Connelly is attorney for the Philadelphia Warehousing and Cold Storage Company, and has made a close study of the cold storage business, which is essential to the proper preservation of food products.

Louis Graff will also serve on the committee. He is president of the Commercial Exchange and is interested in farming on his personal account. Mr. Graff is in close touch with the grain markets, not only of Philadelphia, but throughout the country.

Director George W. Norris has taken particular interest in the development of the city of Philadelphia and recognizes the importance of bringing the farmers of the surrounding territory in close touch with the city.

Clarence Sears Kates has been, for many years, interested in the question of agriculture. He is a member of the Executive Committee of the Philadelphia Society for Promoting Agriculture, vice-president of the Pennsylvania Rural Progress Association, member of Pennsylvania State Grange, and has always taken a personal interest in these public questions and owns a three hundred and fifty acre farm. Mr. Kates will act as secretary for the Bureau.

\section{PlaN OF WORK.}

The Philadelphia Agricultural Service Bureau will endeavor to work along the following lines:

First.-Supplying agricultural information to growers and producers; answering inquiries of farmers along those lines; placing him in communication with responsible distributors to the mutual advantage of the farmer and the Philadelphia market.

Second.-Assisting banks and financial institutions to develop agriculture in their particular sections by arranging for agricultural meetings, supplying speakers and helping with agricultural contests and shows.

Third.-Standardization. In other words, recommending methods to standardize the farm products beginning with the seed, then harvesting, sorting, and placing in such standard package as best practice demands. This work is of primary importance, and is the keynote for the farmer's selling his produce to his best advantage.

Fourth.-Stimulating the establishment of farm bureaus in all counties, so that information may be quickly obtained from the agent in charge, and given directly to the farmer on his own farm. This for the purpose of increasing the farmer's management efficiency, which will tend to reduce his cost of production and increase the size of his crop.

Fifth.-Establishing connections with the county agents, farmers' associations, etc., wherever located, and the Philadelphia Agricultural Service Bureau for interchange of information, both as to supplies for the farms and for produce for the Philadelphia market. 
269

Sixth. -To stimulate the making of soil surveys and farm managemont surveys.

All communications should be addressed to the Honorary Secretary, Clarence Sears Rates, Corn Exchange Bank Building, Second and Chestnut streets, Philadelphia, Pa.

The Bureau has informally already accomplished good. It is daily

- having inquiries from farmers, out-of-town banks and business men for advice as to the improvement of agricultural conditions in the four states. We helped to secure for the Farm Bureau in West Chester, through the County Commissioners, $\$ 1,000$, and we are endeavoring at the present time to have a county agent established in Fayette County and Monroe County. The Philadelphia Vegetable Growers' Association (a new lassociation just started at Bustleton), has asked the Bureau to help them in trying to secure the convention of the Vegetable Growers' Association of America, to be held in October, for this city. We have promised our support to this, and plans are already under way to endeavor to have the convention held here. 






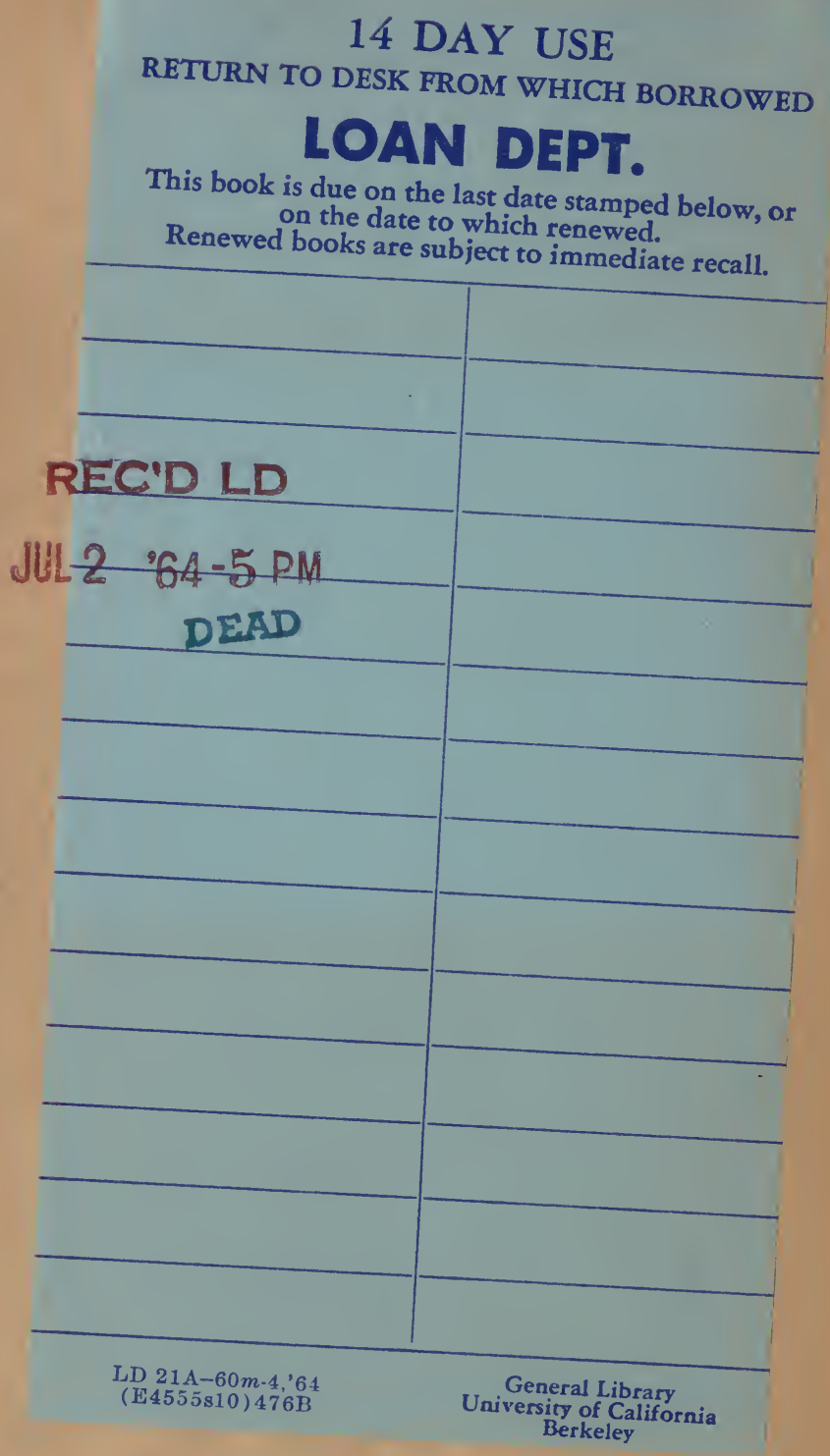


661715
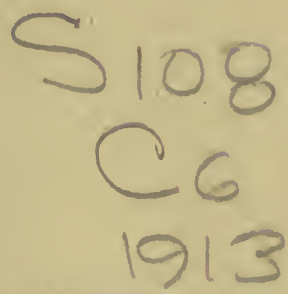

UNIVERSITY OF CALIFORNIA LIBRARY 
